Marco Antônio Leite Massari

ARQUITETURA INDUSTRIAL EM SOROCABA:

O Caso das Fábricas Têxteis 

Marco Antônio Leite Massari

\section{ARQUITETURA INDUSTRIAL EM SOROCABA: \\ O Caso das Fábricas Têxteis}

Dissertação apresentada à Faculdade de Arquitetura e Urbanismo da Universidade de São Paulo, para a obtenção do grau de Mestre em Arquitetura e Urbanismo

Área de concentração: História e Fundamentos da Arquitetura e do Urbanismo

Orientadora: Profa. Dra. Mônica Junqueira de Camargo 
AUTORIZO A REPRODUÇÃO E DIVULGAÇÃO TOTAL OU PARCIAL DESTE TRABALHO, POR QUALQUER MEIO CONVENCIONAL OU ELETRÔNICO, PARA FINS DE ESTUDO E PESQUISA, DESDE QUE CITADA A FONTE.

E-MAIL: marcomassari15@usp.br

Massari, Marco Antônio Leite

M414a Arquitetura industrial em Sorocaba: o caso das fabricas têxteis / Marco Antônio Leite Massari. --São Paulo, 2011.

154 p. : il.

Dissertação (Mestrado - Área de Concentração: História e Fundamentos da Arquitetura e do Urbanismo) - FAUUSP.

Orientadora: Mônica Junqueira de Camargo

1.Edifícios industriais (Preservação) - Sorocaba(SP) 2.Patrimônio arquitetônico - Sorocaba(SP) 3.Indústria têxtil - Sorocaba(SP) I.Título

CDU 72.025.3 
O presente trabalho foi realizado com apoio da FAPESP - Fundação de Ampara à Pesquisa do Estado de São Paulo.

Processo FAPESP № 08/51768-8 
Para meus amados pais, Marco Tulio e Maria Cecilia... 
À FAPESP pela concessão de bolsa de estudos para a realização desta pesquisa com dedicação exclusiva.

À minha orientadora Profa. Dra. Mônica Junqueira de Camargo, pelos ensinamentos e pelo apoio durante todo o desenrolar da pesquisa, assim como durante meus estágios no Programa de Aperfeiçoamento de Ensino e também durante às disciplinas cumpridas.

À Profa. Dra. Beatriz Mugayar Kühl, pela leitura cuidadosa e pelas observações e conselhos feitos durante o Exame de Qualificação. Também gostaria de mencionar toda a atenção e paciência para com todas as minhas dúvidas e questionamentos durante as disciplinas cursadas, durante as supervisões do estágio PAE e durante os cafés e intervalos de aula.

Ao amigo e professor Dr. Ricardo Hernàn Medrano, orientador de minha iniciação científica (PIBIC) e do meu Trabalho Final de Graduação, cursados na Faculdade de Arquitetura e Urbanismo da Universidade Presbiteriana Mackenzie. Pelo incentivo e encorajamento durante todo o processo seletivo para o programa de mestrado, assim como toda a ajuda para a elaboração do projeto de pesquisa. Por fim, pela atenta leitura e considerações acerca de meu Exame de Qualificação.

À Renata Medrano, pelas conversas, pela ajuda e por toda a delicadeza para comigo durante o processo seletivo para o programa de mestrado, assim como durante toda a pesquisa.

Aos meus colegas do Programa de Aperfeiçoamento de Ensino - PAE, Rafael, Pedro e Edmir, pelas diversas discussões e bate-papos

Aos amigos Angela R. Rodrigues e André R. Rodrigue grandes companheiros de viagem. Espero um dia voltar a viajarmos juntos.

Aos colegas do grupo de pesquisa Patrimônio Ferroviário (FAUUSP) Antonio Soukef Junior, Georgia Carolina Carvalho Martins e Cristina Campos pelas trocas de idéias e pela enorme força depositada em meu trabalho

Aos colegas do Instituto Histórico geográfico e Genealógico de Sorocaba, pelo convite e pela confiança em mim depositada, em especial para os diretores Dr. Hang-Ly H. de Ikegami Rochel e o Prof. Adilson Cezar.

A todas as instituições e bibliotecas visitadas. 
Aos antigos proprietários Carlos Alberto e Zuleica Sucupira Kenworthy por dividir momentos pungentes de suas vidas.

Aos ex-funcionários entrevistados, em especial ao Sr. Domingos, portoda a paciência e disposição em mostrar como toda a Vila de Santa Rosália havia sido construída.

Aos autores Prof. Dr. Paulo Celso (UNISO), ao jornalista Wesley Carlos da Silva e ao Sr. Antonio Fiorotto Filho, por disponibilizar parte do acervo pessoal para a esta dissertação.

Ao Gilberto Tenor pela paciência e gentileza em compartilhar seu acervo de livros e imagens de Sorocaba, além da ajuda e conselhos sobre fontes de pesquisa e acervos particulares.

À Arquiteta Luciana Gonçalves Valsechi por ceder uma cópia de sua monografia de especialização patrimônio arquitetônico.

Aos eternos amigos Diogo Giovannoni, Bruno Moreno, Marcel Barbosa e Gustavo Weiss, este, em especial pelo levantamento fotográfico do Parque das Laranjeiras.

À Família Almeida Lima, por me acolher como um filho.

A minha noiva Catia Helena de Almeida Lima por toda a paciência, compreensão e amor incondicional durante a realização desta pesquisa.

Por fim, mas não menos importante, a toda a minha família, em especial à minha avó Georgina por todo o cuidado e carinho durante toda a minha vida. 
"Quando o apito da fábrica de tecidos vem ferir meus ouvidos eu me lembro de você..."

Noel Rosa ["Três Apitos", 1933] 
Esta dissertação de Mestrado discorre sobre a Industrialização de Sorocaba (SP), tendo como caso de estudo as primeiras grandes indústrias têxteis da cidade fundadas entre os anos de 1881 e 1913. Trata-se das indústrias: Fábrica Nossa Senhora da Ponte, Fábrica Santa Rosália, Fábrica Santa Maria, Alvejaria, Tinturaria e Estamparia São Paulo e Fábrica Santo Antônio. Inserido dentro da temática do patrimônio industrial, procuramos dialogar sobre os porquês de esses exemplares serem dignos de preservação, analisando o que foi feito pelo poder público e pela sociedade civil em prol deste objetivo, expondo diversas incongruências na maneira como se sucedeu essa preservação. Apoiada em uma rica documentação fotográfica, buscamos apresentar um levantamento histórico das cinco fábricas salientando as inter-relações existentes entre elas, desde a fundação, até os dias atuais. Além disso, também utilizamos de documentos relacionados aos processos de tombamento, juntamente com uma extensa pesquisa em jornais de época, entrevistas com ex-funcionários e antigos proprietários, e também visitas de campo, permitindo assim um quadro abrangente dos objetos de estudo. Por fim, salientamos não termos colhido respostas definitivas às questões pesquisadas, mas indagações para futuras novas pesquisas que possam trazer esperança de que seja possível modificar a postura para com esses bens, tanto da parte dos órgãos públicos de preservação, quanto da sociedade sorocabana em geral, assegurando assim que as futuras gerações tenham acesso ao enorme conhecimento que estes bens, verdadeiros documentos históricos, são detentores.

Palavras-Chave: Patrimônio Cultural - Industrialização - Sorocaba (SP) 
This master's degree dissertation discourses about the industrialization of Sorocaba (SP), having as a case study the early big textile industries of the town, founded between the years of 1881 and 1913. These are the following: Fábrica Nossa Senhora da Ponte, Fábrica Santa Rosália, Fábrica Santa Maria, Alvejaria, Tinturaria e Estamparia São Paulo e Fábrica Santo Antônio. Inserted in the set of themes of industrial heritage, we have sought to talk about the reasons for these specimens to be worth of preservation, by analyzing what was done by the Public Law and by the civil society in favor of this objective and by exposing several incongruences in the way how this preservation took place. Based on a rich photographic documentation, we sought to present a historical survey of the five factories, pointing out the interrelations existing among them, from the foundation until the present days. Apart from that, we also made use of documents related to the processes of governmental trust, along with an extensive research in seasonable newspapers, interviews with former employees and old owners, and likewise visitations to sites, thus allowing a comprehensive picture of the objects of study. In the end, we emphasized not having collected definite answers to the researched questions, but inquiries for future new researches that might bring hope that modifying the attitude towards these movables might be possible, both from the preservation public agencies' side and from the Sorocabana society's in general, thus assuring that the forthcoming generations may have access to the massive knowledge of which those movables, veritable historical documents, are detainers.

Key words: Cultural Heritage - Industrialization - Sorocaba (SP) 
SUMÁRIO

APRESENTAÇÃO

PARTE A - As Primeiras Grandes Indústrias Têxteis de Sorocaba: um marco divisor 18

Breve Panorama da Industrialização e da Estrutura Urbana de Sorocaba 18

O Parque Industrial Têxtil de Sorocaba 20

Nossa Senhora da Ponte, a Primeira das Grandes Fábricas Têxteis 20

Os Edifícios da Fábrica Nossa Senhora da Ponte 28

A Fábrica Santa Rosália e sua Aprazível Vila Operária 48

Kenworthy e a Companhia Nacional de Estamparia - CNE 58

A Gestão Pereira da Silva 79

PARTE B - Os dias de Hoje: uma análise crítica 108

Fábrica Nossa Senhora da Ponte e Santo Antonio

Fábrica Santa Maria

Fábrica São Paulo

Usina Diesel

Fábrica Santa Rosália 
Manchester Paulista. Assim já foi chamado o município de Sorocaba, localizado na região sudoeste do Estado de São Paulo, distante 96 km da Capital. Recebeu este título em alusão à cidade de Manchester, Inglaterra, pela grande quantidade de fábricas e indústrias têxteis que se instalaram em Sorocaba no fim do século XIX e início do século XX, além é claro, do pioneirismo de sua industrialização.

Durante um curto espaço de tempo, a cidade de Sorocaba vivenciou uma mudança radical em sua sociedade, cultura, economia e urbanização. De uma cidade pequena e pacata, com a economia baseada no comércio de animais e na pequena produção de manufaturas artesanais voltadas a esse universo tropeiro, transformou-se num pólo industrial têxtil e ferroviário, dos mais importantes do estado e do país.

Em menos de 40 anos - da inauguração da Estrada de Ferro Sorocabana em 1875, à fundação da Companhia Nacional de Estamparia (CNE, considerada a primeira holding do país ${ }^{1}$ ) em 1909 - a cidade se reinventou: outrora todos os acontecimentos da cidade, que giravam em torno do tropeirismo e das famosas feiras de muares, passaram a se pautar pelo desempenho dessas empresas. A cidade, antes marcada pelos imponentes sobrados, antigos casarões e pela taipa de pilão, agora se norteia pelas chaminés fumegantes e pelas construções de alvenaria de tijolos. ${ }^{2}$

Deste embrião surgiram grandes nomes de empresários brasileiros, que viriam a se tornar donos de verdadeiros impérios fabris, como os Scarpa, os Pereira Ignácio (seguido pelo genro José Ermírio de Moraes), os Matarazzo, os Pereira da Silva...

\footnotetext{
${ }^{1}$ FRIOLI, Adolfo, BONADIO, Geraldo (org.). Sorocaba 350 Anos: Uma História llustrada, Sorocaba: Fundação Ubaldino do Amaral, Abr. 2004, p.158.

${ }^{2}$ A Estação da Sorocabana foi o primeiro prédio da cidade de Sorocaba a ser edificado utilizando a técnica construtiva de alvenaria de tijolos. Esta edificação também foi a primeira da cidade a ser construída utilizando dos serviços de um profissional, no caso o arquiteto Cantarino, autor de vários projetos de destaque na época, como o Hospital da Beneficência Portuguesa em São Paulo e o do Teatro Municipal de Campinas. IN: Prestes, Lucinda Ferreira. Sorocaba, o Tempo e o Espaço Séculos XVIII-XX. . Tese (Doutorado) - FAUUSP. São Paulo: s.n., 2001.
} 
Desta fase econômica do município, nos chegou aos dias atuais inúmeros exemplares arquitetônicos e urbanísticos dotados de interesse histórico-cultural dignos de preservação. É nesse tocante que esta pesquisa procura trabalhar: na preservação das primeiras grandes fábricas têxteis de Sorocaba. Por que são dignas de preservação? 0 que preservar? Como preservar? São perguntas chave neste trabalho, juntamente com a análise do que foi feito pelo poder público e pela sociedade civil em prol desta preservação.

Ainda garoto, sentia-me incomodado com a maneira pela qual os bens culturais de minha cidade natal eram (mal) tratados. Nessa ocasião meus conhecimentos acerca de arquitetura e preservação eram intuitivos, ou quem sabe inconscientes, pois ainda não tinha clareza de que tipo de formação eu iria me orientar.

Esta dissertação configura-se como um natural desdobramento e complementação de uma pesquisa de iniciação científica do Programa Institucional de Iniciação Científica (PIBIC/Mackenzie) elaborada com apoio do Conselho Nacional de Desenvolvimento Científico e Tecnológico - CNPq durante os últimos anos da graduação na Faculdade de Arquitetura e Urbanismo da Universidade Presbiteriana Mackenzie, juntamente com um Trabalho Final de Graduação - $\mathrm{TFG}^{3}$, ambos orientados pelo Professor Dr. Ricardo Hernàn Medrano. Em meu trabalho de Iniciação Científica optei por estudar apenas um exemplar destas fábricas, a Fábrica Santa Rosália, juntamente com sua vila operária, porque era a escolha possível e sensata para meus alcances acadêmicos e de conhecimento. Se isso atendeu às minhas limitações no momento, deixou-me incomodado e com o incentivo de querer estudar mais amplamente o tema. Deste modo, os demais exemplares industriais precisavam de um estudo detalhado, o que

\footnotetext{
${ }^{3}$ MASSARI, Marco Antônio Leite; MEDRANO, Ricardo Hernàn. Arquitetura Industrial e Inserção Urbana: o Caso da Fábrica Santa Rosália em Sorocaba. In: IV Coloquio Latinoamericano e Internacional sobre Rescate y Preservación del Patrimonio Industrial, 2007, Buenos Aires. IV Coloquio Latinoamericano e Internacional sobre Rescate y Preservación del Patrimonio Industrial. Buenos Aires : Cedodal, 2007; MASSARI, Marco Antônio Leite; MEDRANO, Ricardo Hernàn. Arquitetura Industrial e Inserção Urbana: o Caso da Fábrica Santa Rosália em Sorocaba. In: III Jornada de Iniciação Científica PIBIC e PIVIC Mackenzie, 2007, São Paulo. III Jornada de Iniciação Científica PIBIC e PIVIC - Mackenzie. São Paulo: Mackenzie, 2007 e MASSARI, Marco Antônio Leite. Arquitetura industrial. Trabalho Final de Graduação TFG. Faculdade de Arquitetura e Urbanismo/Universidade Presbiteriana Mackenzie, São Paulo, 2007.
} 
acredito pôde vir a significar a continuação de um trabalho bem sucedido e o preenchimento de uma lacuna que pudesse ser ocupada.

Portanto, acreditei que poderia me expandir mais na busca de novos elementos, que pudessem contribuir para o estudo de parte da história da industrialização de Sorocaba, juntamente com a análise das diversas incongruências de sua preservação. O desenrolar de meus estudos levou-me a constatação da falta de critérios e conhecimento dos princípios que norteiam a preservação de bens culturais. Dessa forma era inevitável fugir de uma indagação intrigante: como poderia uma cidade com tamanha importância para a história da industrialização brasileira não preservar os testemunhos deste passado?

Nesta atual pesquisa foram incluídas também as Fábricas Nossa Senhora da Ponte (também chamada de Fábrica Fonseca), a Fábrica Santa Maria, a Alvejaria, Tinturaria e Estamparia São Paulo e a Fábrica Santo Antônio, todas implantadas entre os anos de 1881 e 1913.

$\mathrm{Na}$ ânsia em querer desvelar o máximo que o tema poderia trazer de conhecimento, tive a esperança de que seria possível chegar a esse objetivo. Como só pode acontecer quando se é movido pela paixão (necessária para podermos empreender qualquer projeto), chegou o momento em que, o confronto com a realidade me fez constatar a impossibilidade de chegar a tal ponto. Esse confronto foi determinado ao me deparar com as limitações e dificuldades encontradas ao longo da pesquisa.

Durante a trajetória da pesquisa, constatei dificuldades previsíveis, tais como, a restrita bibliografia referente à arquitetura e urbanismo de Sorocaba, além da falta de um arquivo público municipal onde pudesse ter acesso a projetos e documentações antigas. Esses aspectos propiciaram grande motivação como parte do tema da dissertação de Mestrado, justamente por ser uma tentativa de preenchimento desta lacuna do conhecimento. Por outro lado, encontrei dificuldades não esperadas. Entre outras: a precária situação do acervo referente às fábricas têxteis nos diversos locais pesquisados; a burocracia e o tempo de espera para ter acesso a documentos em 
alguns órgãos públicos; e, por fim, mas não menos importante, o desinteresse de alguns funcionários, de determinados órgãos, em ceder entrevistas ou materiais de apoio para o trabalho em questão.

Através de relatos de entrevistados, também pude constatar que muitos materiais se perderam ou foram descartados (jogados no lixo) pela falta de interesse em registrar a belíssima história desses empreendimentos, fato ligado à ignorância de antigos funcionários responsáveis pelos arquivos e documentos, ou até mesmo à política de preservação da Prefeitura Municipal de Sorocaba, que simplesmente se desfaz de muitos materiais que não possuem mais valor legal atualmente, mas que com absoluta certeza possuem alto valor documental para a elaboração de inúmeras pesquisas em diversas áreas do conhecimento.

Foi um tanto delicada a organização do trabalho, principalmente porque na etapa de coleta de dados e materiais gráficos pude perceber que houvesse encontrado aspectos inéditos, polêmicos e/ou de difícil acesso. Devo confessar ter ficado seduzido pela possibilidade de impacto desses dados e até impelido a querer me aprofundar mais e mais nos aspectos históricos aos quais eu estava tendo contato. Nesse sentido sou grato às recomendações de minha orientadora (juntamente com a banca de qualificação), que me convidou e me remeteu a uma condição mais realista, propondome quais as bases e rumos que eu poderia escolher no desenvolvimento desta pesquisa.

Com isso definiu-se que deveríamos mostrar apenas parte do material coletado, pois era o possível e mais lúcido para o momento. O restante do material poderá ser utilizado em pesquisas futuras.

É de suma importância enfatizar que este trabalho procurou se alicerçar na rede de relações estabelecidas entre os cinco empreendimentos industriais, para justificar a preservação destes bens culturais, arquitetônicos e urbanísticos, como também, da cultura e memória operária destes locais. Devido a essas relações é impossível "desconectarmos" uma indústria da outra, ou seja, torna-se insatisfatória a 
preservação e a visão dessas fábricas/bairros operários em separado. Claro está que não pretendemos criar ou estabelecer uma visão definitiva sobre o tema. Contudo, a visão atual adotada pelo conselho local não foi e nem está sendo satisfatória para estes bens, vide os diversos exemplos que serão apresentados durante o trabalho. Também é lógico que a mudança de postura para com estes bens não é apenas na maneira como devemos encará-los (em conjunto), mas também, toda uma reestruturação das políticas públicas municipais para com a preservação em geral.

Constatar durante as pesquisas que a cidade de Sorocaba, uma das mais importantes sedes regionais do Estado de São Paulo, não possui uma legislação, nem incentivos fiscais e nem políticas preservacionistas adequadas foi um choque tremendo. Foi estarrecedor também perceber que seu conselho municipal não possui corpo técnico algum (quanto menos qualificado). Com isso, cometeu (e ainda pode cometer) inúmeros equívocos, que resultaram em perdas irreparáveis para preservação do patrimônio cultural local. Porém, o fato considerado mais marcante e preocupante é que a sociedade, de maneira geral, não se interessa por esta preservação, e com isso não há manifestação ou mobilização para mudar este quadro ${ }^{4}$.

É fundamental, e triste, citar que durante a elaboração deste trabalho muitíssimos bens foram alterados sem o devido cuidado ou perícia, quando não, demolidos parcialmente ou integralmente. Numa espécie de corrida contra o tempo, procuramos elaborar os levantamentos destes imóveis, ruas, praças, bairros e ambiências, necessários para as análises e críticas sobre a situação em que se apresenta a preservação do patrimônio industrial em Sorocaba. Contudo, apesar de concluído este trabalho, uma enorme sensação de "atraso" ainda persiste. É como se esta pesquisa (assim como outras sobre o tema) tivessem surgido tardiamente, procurando apenas mostrar o que já foi perdido. Todavia, resta-nos a esperança de que estas perdas

\footnotetext{
${ }^{4}$ Quase a totalidade de solicitações de tombamento de imóveis na cidade foi feita pelo próprio órgão municipal de preservação, ou por alguma secretaria da Prefeitura Municipal de Sorocaba ou pelo Ministério Público local. Dos 23 bens tombados em nível municipal na cidade, apenas 5 foram solicitados por entidades ou indivíduos da sociedade civil.
} 
irreparáveis sirvam de lição, para que isto não venha a ocorrer futuramente com outros exemplares.

Dessa forma esta dissertação foi organizada em duas partes, sendo a parte A o passado das fábricas têxteis, onde apresentaremos um panorama da industrialização de Sorocaba, além do levantamento histórico dos empreendimentos, que se tornaram objetos deste estudo; breve relato da vida de seus proprietários, da evolução dessas empresas e de todo seu patrimônio edificado, procurando destacar a rede de relações criadas entre elas, fato este determinante para o entendimento da preservação desses bens culturais em conjunto.

Na parte B, retrataremos o momento presente: como esses bens chegaram aos dias atuais, quais deles foram considerados de interesse cultural, como se deu esse reconhecimento da população, além de análises dos processos de tombamento, incluindo os decretos, relacionados à industrialização têxtil. Além disso, relatamos e analisamos também a postura do órgão municipal de preservação para com esses exemplares.

Nas considerações finais procuramos sintetizar o que foi discutido ao longo dessas duas partes, tanto do ponto de vista da importância histórica dessas fábricas e bairros operários, como também do quão nocivo pode ser a falta de um órgão de preservação bem estabelecido para o patrimônio em geral.

Por fim, os resultados aqui colhidos, ao invés de trazerem respostas definitivas às questões levantadas, trouxeram apontamentos para futuras novas pesquisas, de novas formas de abordar estes testemunhos do passado, da quantidade de fatos históricos relacionados à industrialização de Sorocaba que necessitam de estudos pormenorizados e da esperança que a postura para com estes bens, tanto da população quanto do poder público, se modifique.

Quanto maior for o nosso conhecimento sobre seus valores e capacidades, menores serão as probabilidades de perda e destruição. De tal forma que, cada testemunho, 
desde uma pequena ferramenta até um conjunto fabril, encontre razão de ser capaz (como testemunho histórico e espaço útil ao homem) de contribuir ao melhoramento da qualidade de vida de nossa sociedade e assegurar a memória às futuras gerações.

Devido a estes fatos é de fundamental importância a correta atuação dos órgãos de preservação, juntamente com os inúmeros profissionais atrelados à restauração, para assegurar que as futuras gerações tenham acesso ao enorme conhecimento que estes bens, verdadeiros documentos históricos, são detentores. 
PARTE A

\section{AS PRIMEIRAS GRANDES INDÚSTRIAS TÊXTEIS DE Sorocaba: um marco divisor}

\section{Breve panorama da industrialização e da estrutura urbana de Sorocaba}

Situada na região sudoeste do estado (a $96 \mathrm{~km}$ da capital São Paulo), a cidade de Sorocaba foi fundada em 1654 por Balthazar Fernandes, e elevada à categoria de vila em três de março de 1661, sob o nome de Nossa Senhora da Ponte de Sorocaba. No princípio era um pequeno povoado. Sua economia era baseada na subsistência e no bandeirantismo (movimento econômico baseado nas bandeiras, que eram expedições realizadas por homens chamados Bandeirantes ou Sertanistas, que tinham como intuito penetrar nos sertões brasileiros em busca de riquezas minerais, indígenas para serem escravizados ou quilombos para serem destruídos - quilombo: local de refúgio dos escravos no Brasil). O tropeirismo (comércio de animais de transporte, realizado nas chamadas feiras de muares, que serviriam para o trabalho na região das Minas Gerais) foi o fator responsável pelo seu grande crescimento e desenvolvimento nos séculos XVII e XVIII. Este comércio, juntamente com o mercado interno formado pelas atividades artesanais e produção caseira de artigos ligados ao tropeirismo (redes, arreios, armazéns, hospedarias, fábrica de facas, facões, ourivesaria e etc.) iriam ser os únicos elementos de sua economia até meados do século XIX.

Como fato isolado é interessante citarmos a implantação, em 1810, no morro do Araçoiaba, da Real (depois, Imperial) Fábrica de Ferro de São João de Ypanema, marco inicial da siderurgia no país. Neste mesmo local, no fim do século XVI, Afonso Sardinha (e seu filho homônimo) já havia produzido ferro, sendo considerada a primeira tentativa de produção de ferro das Américas ${ }^{1}$.

A riqueza advinda do comércio das tropas torna administrativa e politicamente, a Vila de Sorocaba, no final do século XVIII, a mais importante do interior do planalto

\footnotetext{
${ }^{1}$ ZEQUINI, Anicleide. Arqueologia de uma Fábrica de Ferro: Morro de Araçoiaba, Séculos XVI-XVIII. Tese (Doutorado em Arqueologia Histórica) - Universidade de São Paulo, São Paulo, 2007.
} 
Piratiningano ${ }^{2}$, chegando a se tornar a capital da província de São Paulo (por um breve período - maio de 1842, uma vez que o movimento liberal comandado pelo coronel Raphael Tobias de Aguiar foi contido pelas tropas comandadas pelo então Barão de Caxias).

É através deste acúmulo de bens advindos do tropeirismo que se fez possível a tentativa de implantar fábricas têxteis em território sorocabano.

As primeiras tentativas de investimento em uma indústria têxtil, aos moldes que seguem à revolução industrial ${ }^{3}$ só iriam ocorrer em 1852. A primeira foi de Francisco de Paula Oliveira, que trouxe de São Paulo os primeiros bichos-da-seda, junto com equipamentos por ele mesmo fabricados, vindo a tentar fiar os casulos. Produziu apenas alguns écharpes e não teve êxito na atividade industrial. A outra foi de Manoel Lopes de Oliveira que tentou implantar uma fábrica de tecidos. Teve problemas com o suprimento de matéria-prima (a cultura do algodão herbáceo só chegaria à cidade bem depois disso) e com a qualificação da mão-de-obra. O empreendedor redirecionou seus objetivos: desativou a empresa e posteriormente investiu em máquinas de descaroçar algodão, obtendo sucesso.

No início da década de 1860, difunde-se pela Província e em particular na região de Sorocaba, o plantio do algodão herbáceo, impulsionado pelas empresas importadoras de algodão da Inglaterra. Seria uma fonte alternativa de suprimento das tecelagens inglesas, temporariamente impossibilitadas de serem abastecidas pela cultura de algodão no sul dos Estados Unidos (devido a Guerra da Secessão - 1861/65 - a Marinha, fiel ao governo central, bloqueou os portos sulistas impedindo a continuidade do comércio exterior).

Somava-se agora ao comércio de animais, uma atividade agrícola que favoreceu o surgimento de unidades industriais destinadas ao beneficiamento do algodão:

\footnotetext{
2 BADDINI, Cássia Maria. Sorocaba no Império, Comércio de Animais e Desenvolvimento Urbano. São Paulo: Annablume/FAPESP, 2001.

${ }^{3}$ FRIOLI, Adolfo; BONADIO, Geraldo (org.). Sorocaba 350 Anos: Uma História llustrada, Sorocaba: Fundação Ubaldino do Amaral, Abr. 2004, p.131.
} 
remoção dos caroços, limpeza, compactação e enfardamento. Isso também se deveu ao posterior desinteresse do mercado inglês pela compra do algodão, ao restabelecer a cultura americana do mesmo após o término Guerra civil.

Outro fato relevante é a inauguração da Estrada de Ferro Sorocabana (EFS) em 1875, favorecendo a ligação de Sorocaba com a capital (São Paulo), o transporte de mercadorias e o surgimento do parque industrial têxtil. A iniciativa de um movimento em favor da criação de uma estrada de ferro que ligasse São Paulo a Sorocaba foi do húngaro Luís Matheus Maylasky, engenheiro e ex-oficial do exército de seu país, que também foi um dos grandes responsáveis pela difusão da cultura algodoeira e de seu beneficiamento em Sorocaba.

\section{O Parque Industrial Têxtil de Sorocaba}

O Parque Industrial Têxtil de Sorocaba teve sua origem numa somatória de fatores que se entrelaçam que serão analisados a seguir numa seqüência que evidencia a inseparabilidade da história dessas cinco fábricas têxteis em conjunto.

Contudo, antes de iniciarmos esta descrição, é de suma importância a leitura de um dos relatos mais precisos e tocantes a respeito da cidade de Sorocaba no período de implantação das fábricas têxteis, que é do autor Alfredo Moreira Pinto, que pode ser acessado nos anexos em sua totalidade e que iremos citar em trechos ao longo das informações sobre as fábricas. Moreira Pinto foi historiador, pessoa de espírito desbravador, com grande senso de curiosidade, daí a delicadeza e detalhamento de seu relato sobre Sorocaba. ${ }^{4}$

\section{Nossa Senhora da Ponte, a primeira das grandes fábricas têxteis}

A implantação da primeira indústria têxtil em Sorocaba foi iniciativa do português Manoel José da Fonseca, em 1881, que comprou um grande terreno à margem do córrego Supiriri e lá instalou a Fábrica de Fiação e Tecidos Nossa Senhora da Ponte (conhecida também como Fábrica Fonseca).

\footnotetext{
${ }^{4}$ PINTO, Alfredo M. A Cidade de São Paulo em 1900: Impressões de Viagem. Rio de Janeiro: Imprensa Nacional, 1900.
} 
Fonseca, que nasceu em 21 de outubro de 1846 na cidade portuguesa de Guarda, chegou à Sorocaba aos 17 anos de idade e iniciou sua trajetória profissional trabalhando como caixeiro viajante e guarda-livros (contador) de um estabelecimento comercial no centro da cidade. Em 5 de março de 1871 casou-se com Adelaide Amélia Soares, filha de Manoel José Soares, seu antigo patrão, com quem teve quatro filhos: Isaura, Adélia, Celiza e Wlademir ${ }^{5}$. Pouco tempo depois iniciou seu próprio negócio, “A Loja do Sol", na Rua Barão do Rio Branco (que funcionou na cidade até 1958, porém com diversas alterações de proprietários), tornando-se um rico comerciante. Enriqueceu não somente pelos negócios na loja, mas também pelo seu grande tino empresarial. Ganhou muito dinheiro com o algodão, sem nunca sequer tê-lo plantado:

"comprava algodão em caroço e em rama em Campo Largo, Itapetininga, Guareí e Itapeva. [...] Reexportava, ou antes, embarcava todo algodão, depois de beneficiado nos vagões da Sorocabana. Fazendo bem as contas valia à pena tecer o algodão $e$ vestir as classes pobres e médias do interior" ${ }^{\prime}$.

Apesar de não ter sido um tipo de investimento muito lucrativo, "o súbito progresso da Província, com o aumento da população, garantia a colocação do produto" ${ }^{7}$. Também foi acionista da Companhia Sorocabana, com intensa participação em reuniões e assembléias. Através dela que ele transportava os fardos de algodão negociados. Com todo o conhecimento adquirido nos negócios com algodão, percebeu a possibilidade de altos lucros em produzir e vender tecidos.

A escolha do terreno, que na época pertencia ao quintal de D. Joaquina do Nascimento Ferreira Prestes (viúva do Capitão José Ferreira Prestes) deveu-se a: proximidade de um curso d'água (Córrego Supiriri), tamanho e topografia adequada, além da possibilidade de ter um ramal da Estrada de Ferro Sorocabana, para facilitar o escoamento do material produzido. Outro fator decisivo foi a questão do preço do

\footnotetext{
5 Relatórios Técnicos CMDP (Conselho Municipal de Defesa do patrimônio Histórico, Artístico, Arquitetônico, Turístico, e Paisagístico de Sorocaba). Processo de Tombamento no 1993/09791 3. Fábricas Nossa Senhora da Ponte e Santo Antonio, p.83.

${ }^{6}$ SCHRÖDER, Adelaide de Fonseca Ferreira. Apud BONADIO, Geraldo. Sorocaba: a cidade Industrial (espaço urbano e vida social sob o impacto da atividade fabril). Sorocaba, SP: do Autor, 2004, p.150.

${ }^{7}$ SCHRÖDER Apud BONADIO, Op. Cit. p.151.
} 
terreno: considerado periférico, Fonseca conseguiu estabelecer uma boa negociação com a antiga proprietária.

Manoel José da Fonseca não possuía nenhum conhecimento específico para poder, sozinho, planejar, projetar, construir e colocar em funcionamento uma fábrica de tecidos com tal envergadura. Para isso escolheu Alexandre Marchisio, inglês, nascido na Ilha de Malta, com formação técnica em fiação e tecelagem, para tal função. Foi através dele, que adquiriu, da empresa inglesa Curtis Sons \& Company, com sede em Manchester, as máquinas que iriam operar na fábrica. "Os equipamentos [...] chegam a Santos em 12 de abril de 1882" 8 (45 teares com dois mil fusos), iniciando sua instalação e funcionamento dois meses depois. A fábrica foi inaugurada oficialmente no dia 2 de dezembro de 1882, recebendo o nome da padroeira da cidade. Quatro anos mais tarde recebeu as visitas do Imperador D. Pedro II e da Imperatriz D. Teresa Cristina ${ }^{9}$.

Em relação à construção do edifício: "o madeiramento para o prédio veio da fazenda do Coronel Francisco Ferreira Prestes, perto de Itapeva, bem como da Olaria, os tijolos e as telhas, aos milhares em carros de boi" ${ }^{10}$.

É interessante salientar que desde o início do funcionamento da fábrica, ela manufaturou com mão de obra operária, pois Fonseca era um abolicionista, numa época em que ainda havia mão de obra escrava. Contudo, a cultura da época não coibia, nem tinha estranhamentos ao emprego de crianças, adolescentes e mulheres grávidas. E nem mesmo havia uma legislação que contemplasse uma jornada de trabalho racional. Trabalhavam 10 e até mais de 12 horas por dia.

O impacto causado pela instalação da fábrica não se restringiu apenas à paisagem urbana. Para o funcionamento da empresa era necessário um grande número de

\footnotetext{
8 FRIOLI, Adolfo, BONADIO, Geraldo (org.). Sorocaba 350 Anos: Uma História llustrada, Sorocaba: Fundação Ubaldino do Amaral, Abr. 2004, p. 150.

${ }^{9}$ FRIOLI; BONADIO. Op. Cit. p. 151.

10 Relatórios Técnicos CMDP (Conselho Municipal de Defesa do patrimônio Histórico, Artístico, Arquitetônico, Turístico, e Paisagístico de Sorocaba). Processo de Tombamento № 1993/09791 3. Fábricas Nossa Senhora da Ponte e Santo Antonio, p.84.
} 
recursos (matéria prima, lenha, água, transporte até os pontos de distribuição comerciais próximos, animais para o transporte, etc.). Como conseqüência disso incentivou o comércio desses recursos. Desse modo, nessa época, a expressão "baldear lenha para o Fonseca" ficou bastante conhecida e popular, tamanha era a necessidade desse combustível transportado em lombo de animais ou em carros de bois. O problema do transporte de água foi solucionado em 1885, com a instalação de uma bomba hidráulica, capaz de fornecer a água necessária para o funcionamento das máquinas a vapor. Neste período a fábrica empregava 300 operários e a matéria prima era toda produzida em Sorocaba e nos municípios vizinhos.

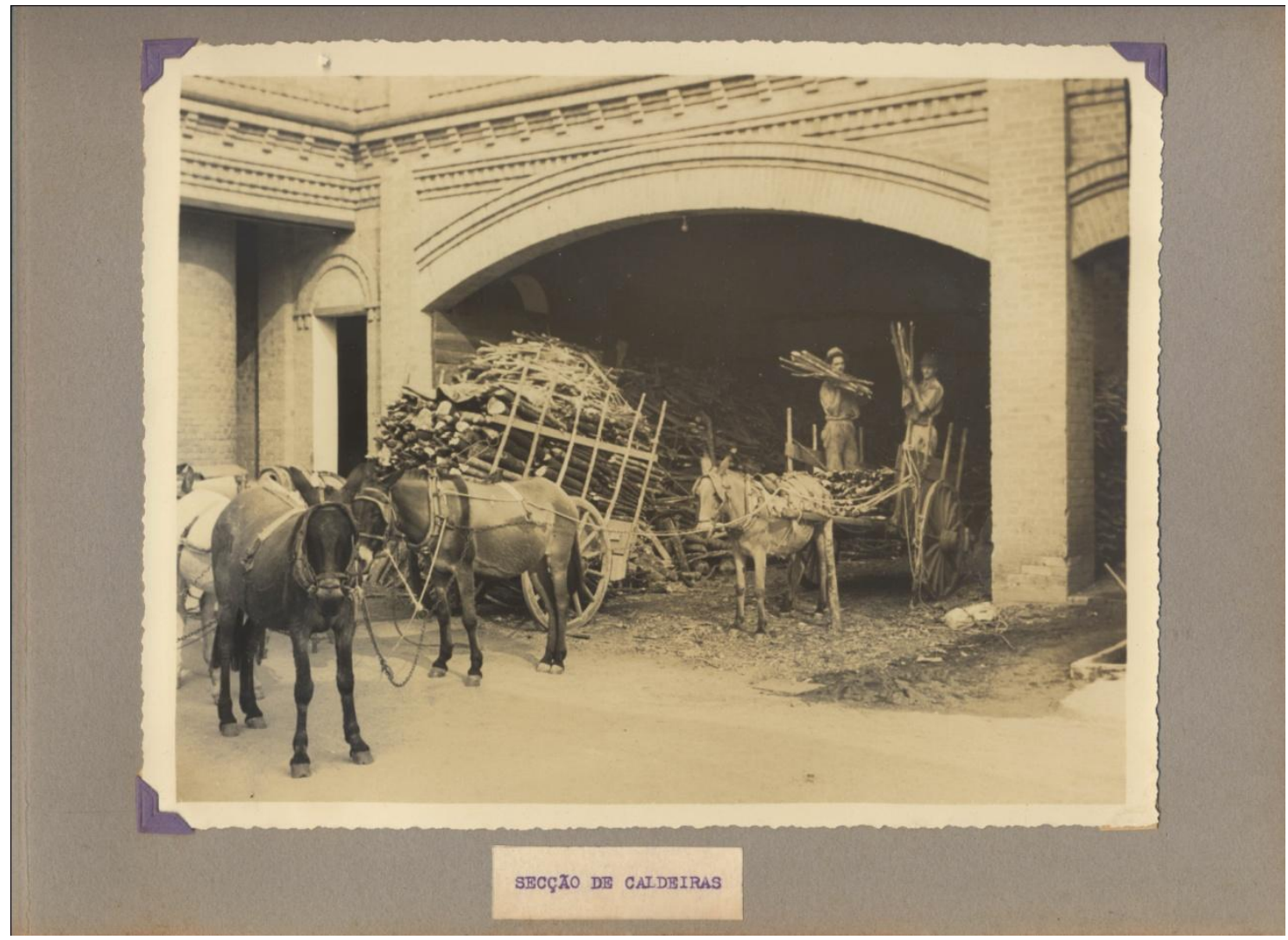

Figura 1: Seção das Caldeiras. Fonte: Acervo Gilberto Tenor (DVD Coleção Wilson Fernandes, Álbum: Nossa Senhora da Ponte - 1944)

Algum tempo após oito anos da instalação da fábrica, com um número satisfatório de vendas e produção, houve um aumento do número de funcionários e ampliação de todas as suas instalações, bem como do número de máquinas. 0 rápido sucesso 
colhido por Manuel José da Fonseca o fez buscar ampliar seus negócios, através da tentativa de sociedade com o alemão Victor Nothmann, para a instalação de uma fábrica em São Paulo. Antes mesmo que as máquinas vindas de Hamburgo desembarcassem no Brasil, a sociedade Nothmann \& Cia. já havia acabado, com enorme prejuízo para o português. Mas a ruptura terminou amigavelmente, em 1895.

Em 1898, como já referimos acima, Alfredo Moreira Pinto esteve em Sorocaba e relatou os seguintes aspectos sobre a Fábrica Nossa Senhora da Ponte:

"Fica situada no fim da rua Santo Antonio, junto ao corrego Supiriry.

Foi fundada em 1881, começando a funccionar no anno seguinte. Teve em seu principio 15 teares, constando actualmente de 75.

E'seu fundador o proprietario o Sr. Manoel José da Fonseca.

Consta de um edificio quadrangular, construido de tijolos e alicerces de granito, coberto de telhas nacionaes, dividido em seis compartimentos para deposito de algodão em caroço e em rama, com machinas para descaroçar, machinas de fiação, engommagem, tecelagem e enfardamento.

A fiação consta de um abridor vertical, dous batedores, quatorze cardas, oito machinas preparadeiras, seis bancas de carreteis e uma mulla de seiscentos fusos. Essas machinas podem fazer fios desde o n. I até 20.

Possue ainda a fiação uma machina dobadoura para fios de coser e uma outra para fios brancos, duas bancas para preparas espulas, um engommador e uma machina automatica com dous agitadores para o preparo da gomma e alimentação do engommador.

Na tecelagem ha duas machinas urdideiras, 60 teares mecanicos simples, um para tecido duplo, e 14 com diversas lançadeiras para tecidos de xadrez.

A secção do enfardamento consta de uma machina telisadora para alisar o panno, duas outras para dobrar e medir, uma ourta para enrolar o tecido em peças e uma prensa hydraulica para fabricação de fardos.

Em edificio separado funccionam a tinturaria e suas dependencias.

Na tinturaria encontram-se um deposito de drogas, tanques de ferro para coser o fio, outros de ferro e madeira para tingir, aquecidos á vapor; turbinas centrifuga para enxugar o fio e uma estufa á vapor, esta no segundo plano do edificio, tendo annexo o deposito de fios tintos.

O motor da fabrica consta de uma machina á vapor de 200 cavallos, systema Corliss, uma caldeira de 30 pés de comprimento por sete de diametro, trabalhando até a pressão de 100 libras, com fornalhas apropriadas para carvão e lenha, sendo o combustivel empregado lenha e sementes de algodão; uma outra caldeira de 14 cavallos para fornecer vapor para a tinturaria e o engommador; dous motores 
verticaes da força de seis cavallos par accionar independentemente o engommador e a officina mecanica.

O movimento principal é transmitido por meio de uma roda volante, de 100 pés de diametro com jabres e sete cabos de duas pollegadas de diametro cada um.

A officina mecanica compõe-se de um torno mecanico, uma machina de aplainar horizontalmente e uma outra para aplainar verticalmente; duas machinas de broquear, uma de afiar serras e uma pequena fundição para metaes.

Toda a agua é extrahida de um poço por meio de uma bomba a vapor, que a transporta para um reservatorio, que tem a capacidade de 30.000 litros.

O pessoal effectivo da fabrica é de 150 operarios.

Seus produtos são vendidos no Rio de Janeiro e S. Paulo.

A fabrica produz diariamente uma média de 5.000 metros, sendo riscados grossos e xadrezes, fabricados com o fio n. 6.

E' ligada á estação central da Sorocabana por uma chave a 400 metros de distancia“" ${ }^{11}$.

Pouco tempo depois, no início da década de 1910 fica evidente que mesmo com todo o sucesso e a prosperidade que a fábrica obtinha, seria necessário um grande investimento para que ela continuasse a manter e aumentar seu sucesso. Para que isso se concretizasse deveria ter um investimento que era além da capacidade de Fonseca. Com isso houve uma mudança na "organização da Companhia Fiação e Tecidos Nossa Senhora da Ponte, com capital de 2.000:000\$000 e a entrada para a diretoria, na qualidade de diretor-gerente, em 1911, do capitalista Joaquim Soares Fernandes, do Rio de Janeiro" ${ }^{12}$. Mesmo assim, para que a fábrica continuasse a crescer, uma nova mudança foi efetuada. Em 1912 Manuel José da Fonseca, presidente da empresa, passa a ser um dos acionistas da nova razão social chamada Sociedade Anônima Nossa Senhora da Ponte, organizada por Bernardo Lichtenfels Senior e Bernardo Lichtenfels Junior $^{13}$. Bernardo Senior passa a ser o novo gerente da fábrica. Fonseca, que já tinha

\footnotetext{
${ }^{11}$ PINTO, Op. Cit. pp. 23-25.

12 BONADIO, Geraldo. Sorocaba: a cidade Industrial (espaço urbano e vida social sob o impacto da atividade fabril). Sorocaba, SP: do Autor, 2004, p.152.

${ }^{13}$ Proprietário do primeiro automóvel de Sorocaba (1904) e antigo proprietário da Empresa Elétrica de Sorocaba, que "iniciou a construção da usina no rio Sorocaba, junto ao Itupararanga, na Serra de São Francisco", vendendo-a, em 1911 para a empresa São Paulo Eletric. FRIOLI, Adolfo, BONADIO, Geraldo (org.). Sorocaba 350 Anos: Uma História Ilustrada, Sorocaba: Fundação Ubaldino do Amaral, Abr. 2004.
} 
certa idade, retira-se dos negócios e muda-se para o Rio de Janeiro, com a filha e netos. Manoel veio a falecer em 14 de outubro de 1914. Neste mesmo ano a fábrica é vendida para Nicolau Scarpa.

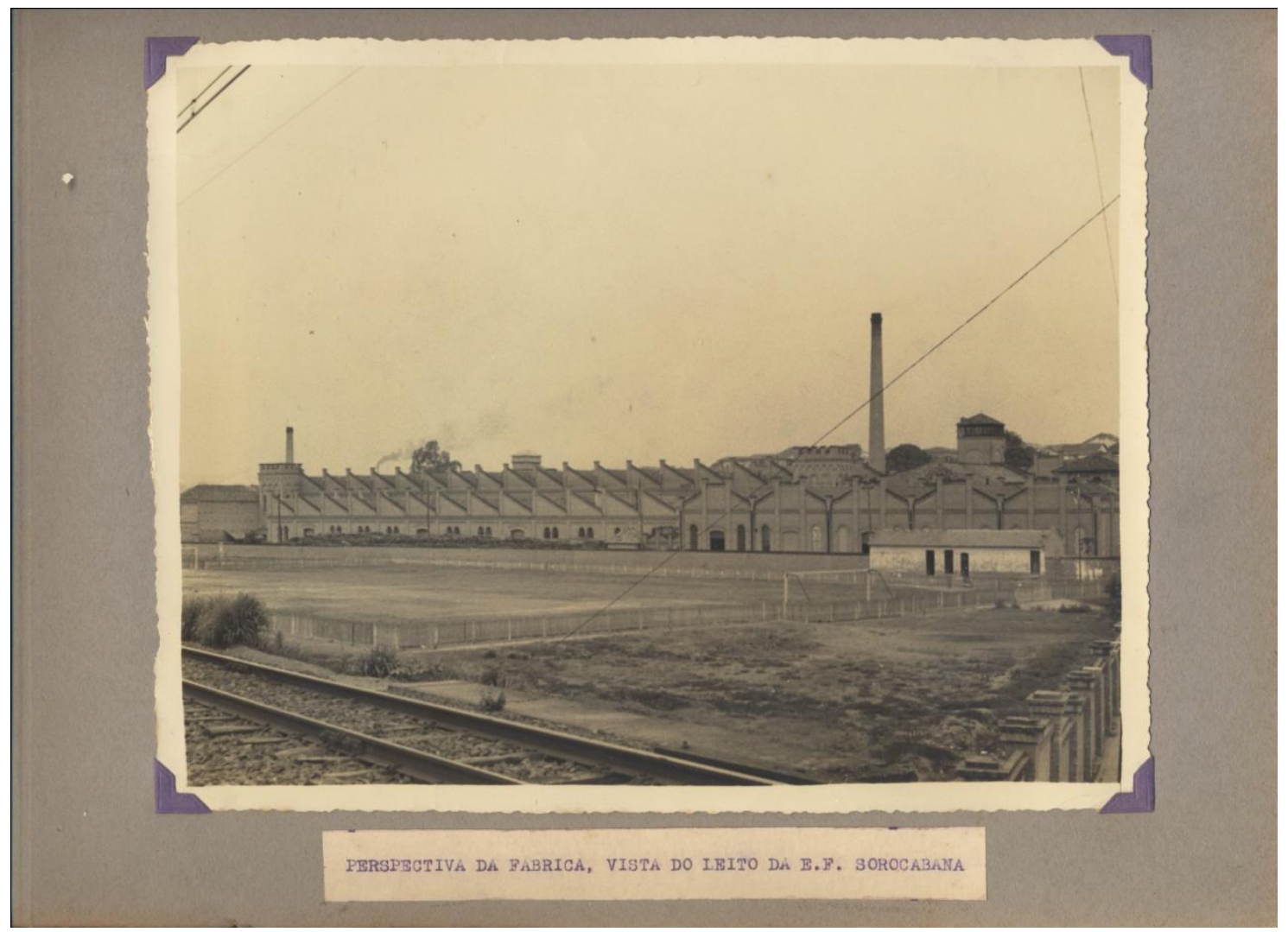

Figura 2: Perspectiva da fábrica, vista do leito da Estrada de Ferro Sorocabana. Fonte: Acervo Gilberto Tenor (DVD Coleção Wilson Fernandes, Álbum: Nossa Senhora da Ponte - 1944)

A família Scarpa havia chegado a Sorocaba em 1885. Vindos da Itália, Francisco Scarpa e seu filho Nicolau iniciaram seus negócios montando um armazém de secos e molhados na Rua Coronel Benedito Pires (no centro da cidade). Com a prosperidade deste armazém, compraram um grande imóvel, surgindo assim, a primeira firma da família, que se chamava Scarpa \& Filho (localizada na Rua Padre Luiz). No andar térreo da propriedade praticavam os negócios da família: compra e venda de algodão. Utilizavam o andar superior como moradia. 


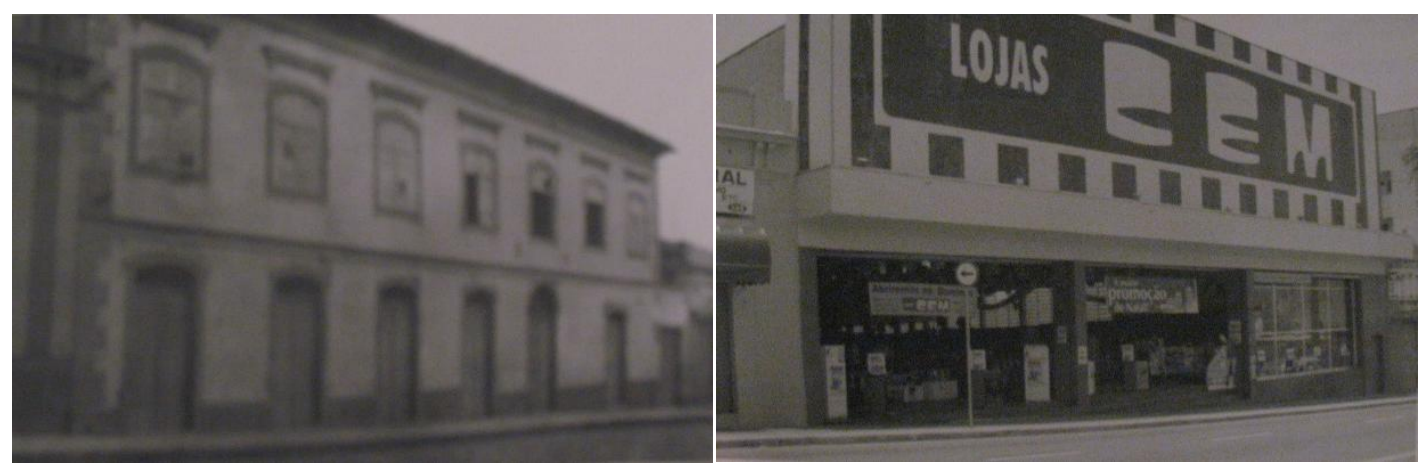

Figura 3: Sobrado dos Scarpa (esq.), lamentavelmente demolido para dar lugar às lojas Cem (dir). Rua Padre Luiz. Fonte: Rangel, Paulo R. Máquinas do Tempo. Sorocaba, SP: Crearte, 2004, p.66-67

Como referimos acima, Nicolau Scarpa efetuou a compra da Fábrica Nossa Senhora da Ponte, vindo a mudar-se com a família para São Paulo em 1918. Os negócios cresciam cada vez mais.

Na capital foram adquirindo o controle acionário de uma série de empresas, incluindo: indústrias de cimento, usinas de açúcar, curtumes, fazendas de gado e a cervejaria Caracu. Alguns negócios eram apenas da família e outros com parcerias de sócios (Assis Chateaubriand).

O herdeiro de Nicolau, Francisco Scarpa, deu continuidade ao império iniciado pelo avô e seu pai em Sorocaba, chegando a ser vice-presidente da cervejaria Skol-Caracu diretor da Companhia Eletrolux S.A. e diretor da Fundação Armando Álvares Penteado (FAAP).

A família Scarpa teve significativa importância no campo social de Sorocaba, através das seguintes iniciativas: doação da construção do pavilhão central da Santa Casa de Misericórdia (década de 20); construção das instalações da Faculdade de Filosofia, Ciências e Letras, na década de 1950, no bairro Trujillo (que dá origem mais tarde à Universidade de Sorocaba - UNISO); constituição da Fundação Scarpa para administrar e manter, com seus recursos próprios, os primeiros anos da faculdade; Ainda na 
década de 50, a doação de dinheiro à Prefeitura Municipal para saldar salários atrasados dos servidores municipais; Ajuda na construção da Faculdade de Medicina (primeira faculdade de medicina do interior do estado) conjuntamente com a doação do Laboratório de Patologia.

A Fábrica Nossa Senhora da Ponte permanece com a mesma estrutura e nome até 1919, quando Scarpa aumenta seu patrimônio adquirindo outras unidades fabris (dentre elas a fábrica de óleo Santa Helena), transformando a Sociedade Anônima Scarpa num verdadeiro conglomerado industrial.

"Em 1933, a empresa então constituída vai à falência. Por posterior decisão judicial, volta aos Scarpa, que a controlam através de uma nova empresa, a Cia. De Fiação e Tecidos Nossa Senhora do Carmo, mantendo a unidade fabril o nome de Nossa Senhora da Ponte" ${ }^{\prime 14}$.

Durante este período da administração é construída, ao lado da fábrica de óleo Santa Helena, a mansão que a família se hospedava ao visitar a cidade: o Palacete Scarpa. Também é desse período a compra do Parque Esportivo Trujilo, que se torna a Associação Atlética Scarpa (Clube Scarpa), que era um grande complexo de lazer para os funcionários, contendo piscinas, campo de futebol, pista de atletismo e sede social. Era localizado próximo à fábrica. Também podemos citar como obra importante na época, a ampliação das instalações da Fábrica Nossa Senhora da Ponte, com um novo e moderno edifício fabril.

A empresa fica em mãos dos Scarpa até finais da década de 70 , quando, através do Grupo Gasparian, é vendida para a Cia. Nacional de Estamparia (por 500 milhões de cruzeiros ${ }^{15}$ ), que será tema a ser tratado posteriormente.

\section{Os edifícios da Fábrica Nossa Senhora da Ponte}

A Fábrica Nossa Senhora da Ponte foi marcada por um peculiar processo de expansão, concomitantemente à evolução das técnicas de fabrico e aperfeiçoamento dos processos de produção.

\footnotetext{
${ }^{14}$ FRIOLI; BONADIO. Op Cit p. 153.

15 JORNAL CRUZEIRO DO SUL. Estamparia Compra a Nossa Senhora do Carmo, 6.5.1981, p. extra.
} 
No início de seu funcionamento, os edifícios existentes abrigavam os setores de fiação e tecelagem apenas. Os outros setores da fábrica como os de acabamento (estamparia e tinturaria), que até então não eram mecanizados, ficavam em áreas externas à produção.

Para fazer frente ao avanço tecnológico e na busca de atualização de processos produtivos, a fábrica passa por uma ampliação bem grande, em $1914^{16}$. Esta medida visava também atender à questão da competitividade expressa pela instalação de outras indústrias na cidade. Nesta expansão, são acoplados ao edifício primitivo seções como: depósito de fios e de modelos, seção de urdideiras, de rocadeiras e de tinturaria. Cabe ressaltar que além dos ganhos na área de produção, neste período podemos também incluir os ganhos na área social, sendo: a creche, Clube Scarpa (com grande área para a prática esportiva onde e sede social), sala de reuniões e biblioteca próximas do perímetro da fábrica - e uma vila operária com 24 casas, com acesso por uma rua interna do complexo (Rua Fonseca).

\footnotetext{
${ }^{16}$ Esta data, assim como as demais datas de ampliação deste edifício são referentes às datas das fotografias contendo estas modificações. Não há registros das datas exatas das transformações.
} 


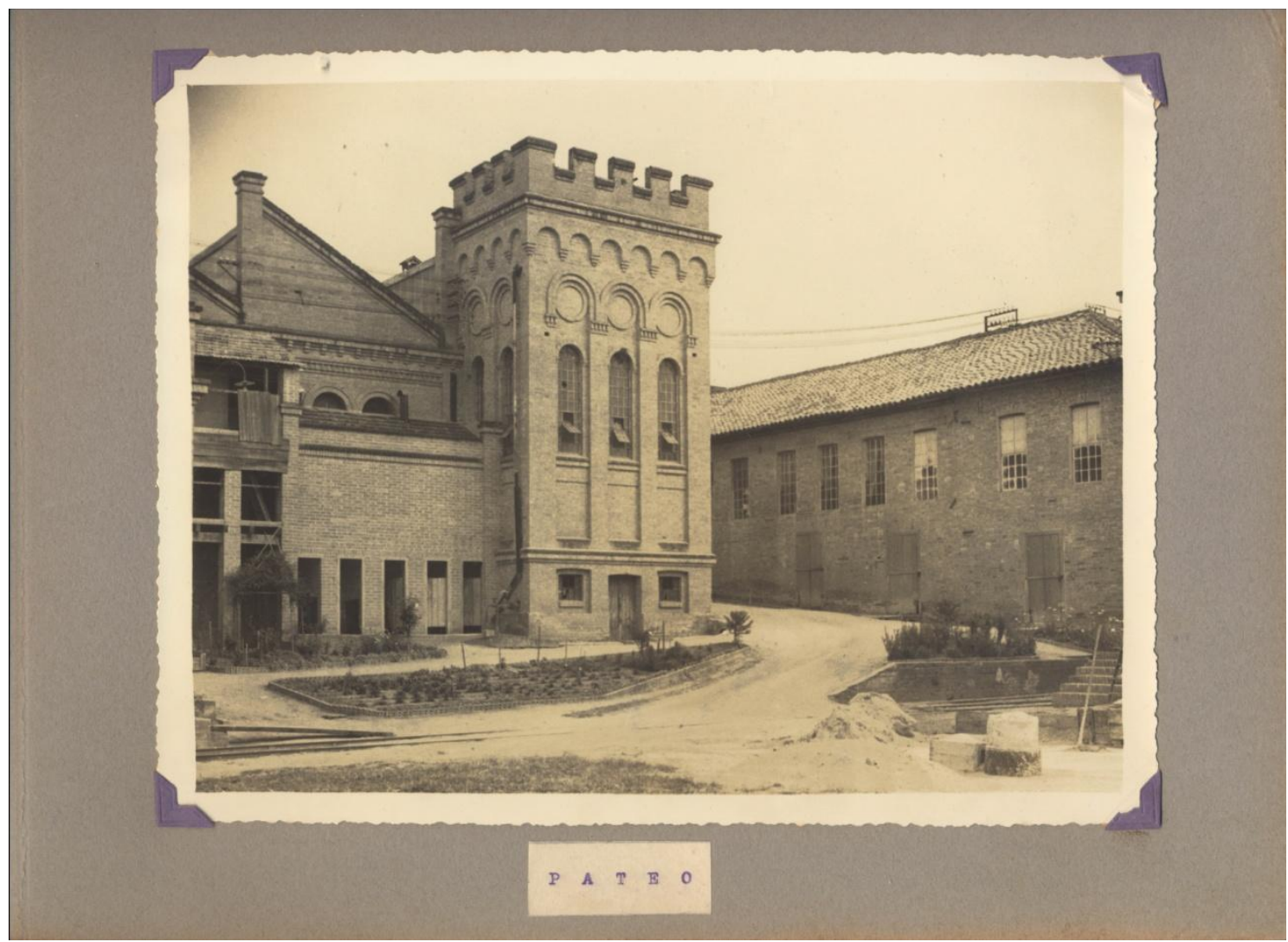

Figura 4: Parte de um dos edifícios construídos na expansão realizada em 1914. Fonte: Acervo Gilberto Tenor (DVD Coleção Wilson Fernandes, Álbum: Nossa Senhora da Ponte -1944)

Anos mais tarde uma nova ampliação é feita para abrigar um novo depósito de tecidos e um novo depósito de fardos de algodão, uma vez que o antigo havia se tornado parte da administração. ${ }^{17}$ A data das imagens contendo estes novos edifícios é 1950, onde podemos também observar um bem cuidado campo de futebol/praça esportiva pertencente à empresa, em terreno compreendido entre a fábrica e a linha férrea (figura 2).

Até então, todas estas ampliações e novas edificações seguiam a tipologia e composição do edifício inicial, caracterizado pelas vedações em tijolos cerâmicos aparentes, superestrutura composta de pilares e vigas em ferro fundido, cobertos por sheds formados por telhas de barro, banhando o interior dos prédios de iluminação natural. Cabe ressaltar também a maestria e esmero do assentamento desses tijolos,

\footnotetext{
${ }^{17}$ VALSECHI, Luciana Gonçalves, Fábrica de Tecido Nossa Senhora da Ponte: Restauro do Antigo Prédio da Tinturaria e Revitalização do Conjunto. Monografia (Especialização em Patrimônio Arquitetônico: Teoria e Projeto) - Pontifícia Universidade Católica de Campinas, 2000, p. 27.
} 
que criavam composições e elementos decorativos fabulosos. A fenestração era basicamente composta de aberturas em arcos plenos com caixilharia de ferro e fechamentos em vidro. Contudo, no edifício administrativo (ao lado da entrada principal - pela antiga Rua Santo Antonio, atual Rua Francisco Scarpa), podemos perceber a presença de janelas retangulares de madeira do tipo guilhotina (Figura 5).

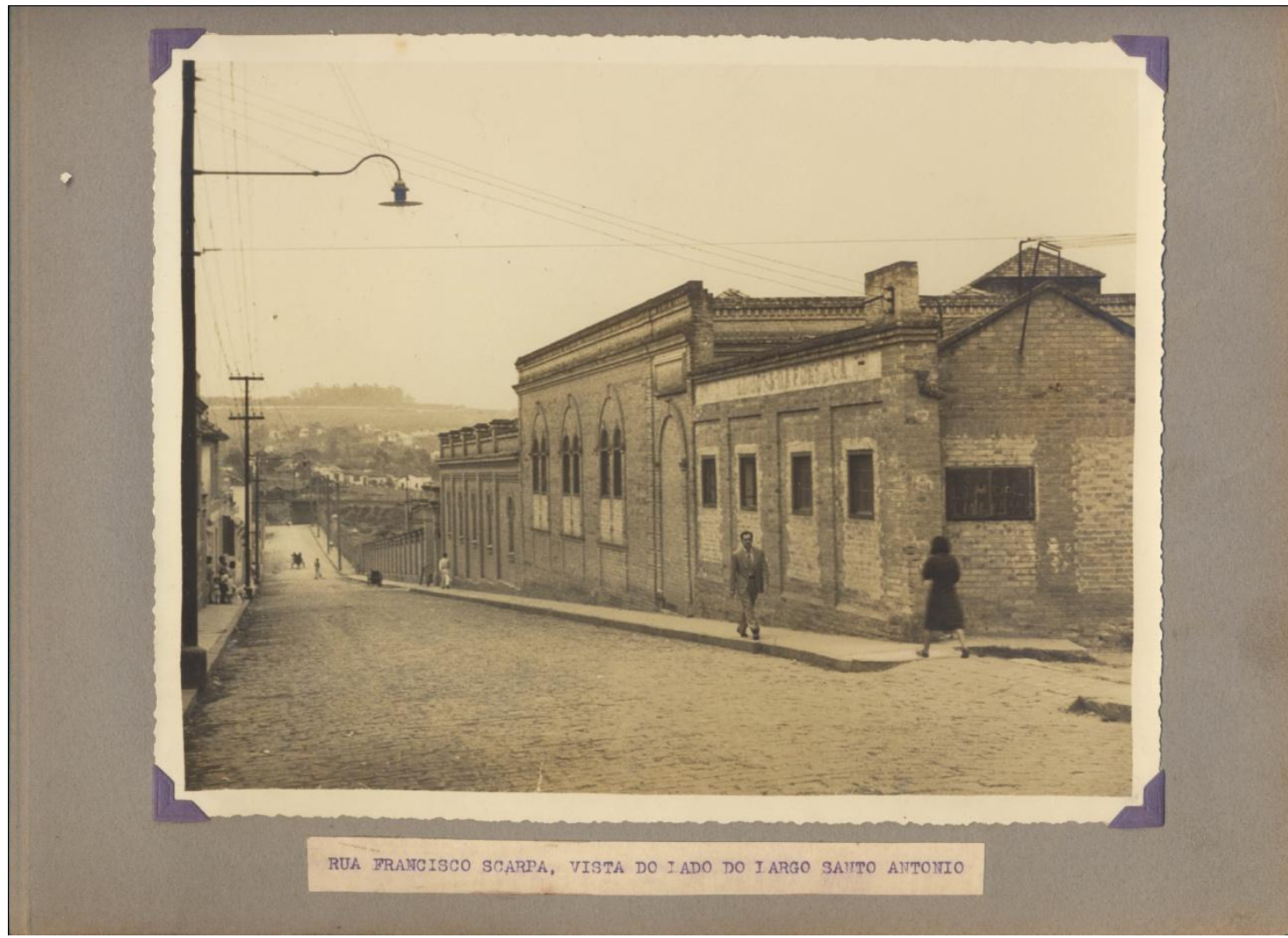

Figura 5: Edifício Administrativo da Fábrica Nossa Senhora da Ponte. Fonte: Acervo Gilberto Tenor (DVD Coleção Wilson Fernandes, Álbum: Nossa Senhora da Ponte - 1944) 
Em iconografia da década de 1960 um enorme pavilhão novo é edificado, desta vez em discordância à arquitetura praticada até então. Um edifício moderno é implantado em meio a todos aqueles edifícios de tijolos (na área onde anteriormente era o campo de futebol/praça esportiva), causando total dissonância ao conjunto.

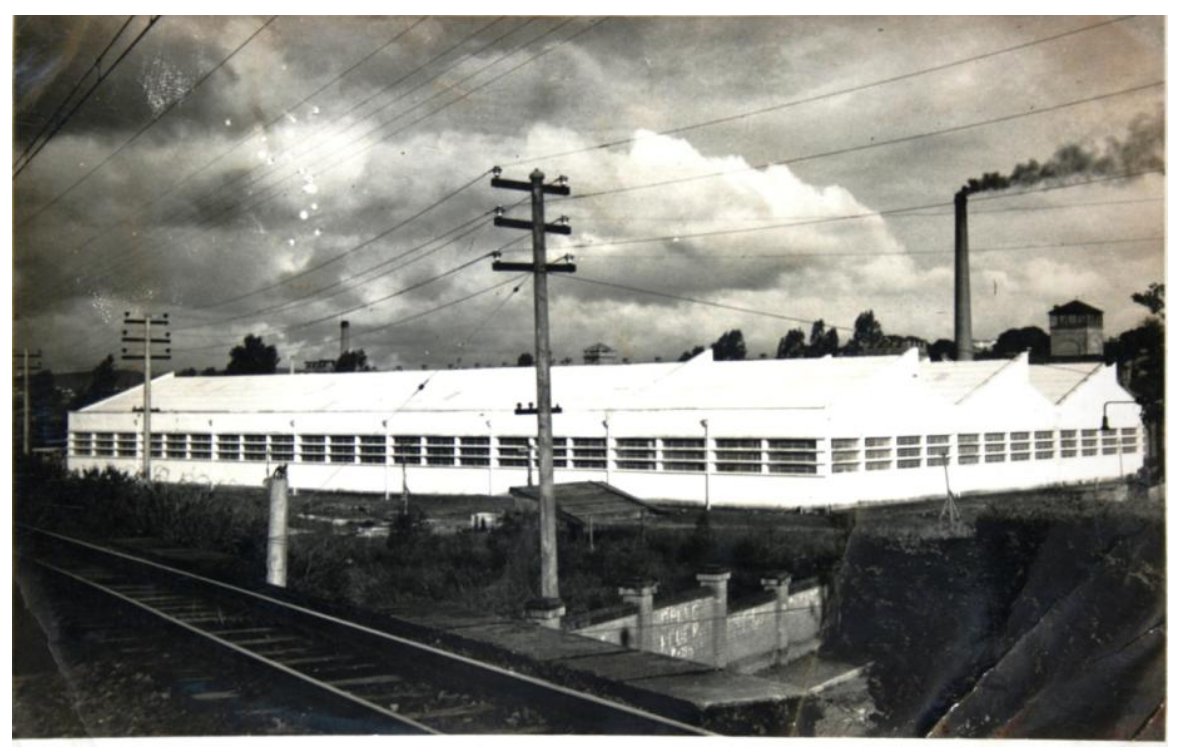

Figura 6: O novo edifício da Fábrica Nossa Senhora da Ponte. Fonte: IHGGS, 1950 (?)

Na década de 1970 uma nova avenida é implantada na cidade (fazendo parte de um novo anel viário urbano - a Avenida Afonso Vergueiro). Para isso, parte deste novo e moderno edifício é removida, criando uma cisão entre a fábrica e o ramal da Sorocabana (além de uma incomoda sensação ao observador de que o edifício havia sido "cortado" ${ }^{18}$ ). Na década seguinte, observamos a demolição da antiga vila para a construção de um depósito de máquinas.

A sua desativação, e posterior transformação de parte de seu terreno em terminal municipal de ônibus, marca a maior alteração do conjunto, onde se demoliu inúmeras edificações. 0 detalhamento destas destruições, as tentativas de novos usos, as propostas de uso atuais, assim como todo o processo de tombamento serão descritos na parte B desta pesquisa.

Abaixo, segue o levantamento do processo evolutivo do complexo de edifícios da Fábrica Nossa Senhora da Ponte ${ }^{19}$.

\footnotetext{
${ }^{18}$ VALSECHI, Luciana Gonçalves. Op. Clt. p. 27.

${ }^{19}$ Agradeço a gentileza da arquiteta Luciana Valsechi em ceder uma cópia de seus arquivos digitalizados do levantamento evolutivo dos edifícios da Fábrica Nossa Senhora da Ponte, que é parte integrante de sua monografia de Especialização em Patrimônio Arquitetônico. VALSECHI, Luciana Gonçalves. Op. CIt.
} 


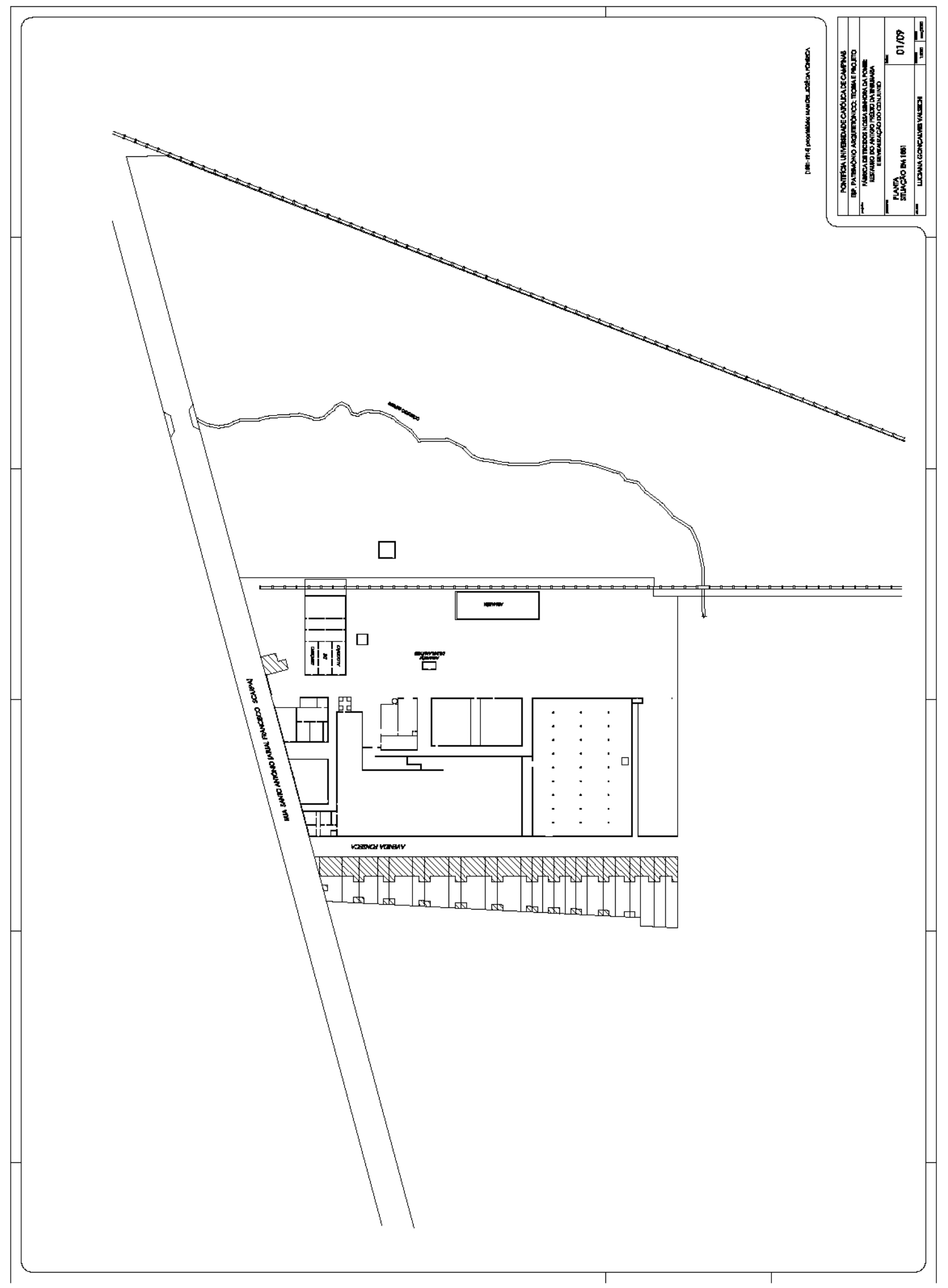

Figura 7: Fábrica Nossa Senhora da Ponte, planta - situação em 1881. Fonte: acervo Luciana G. Valsechi. 


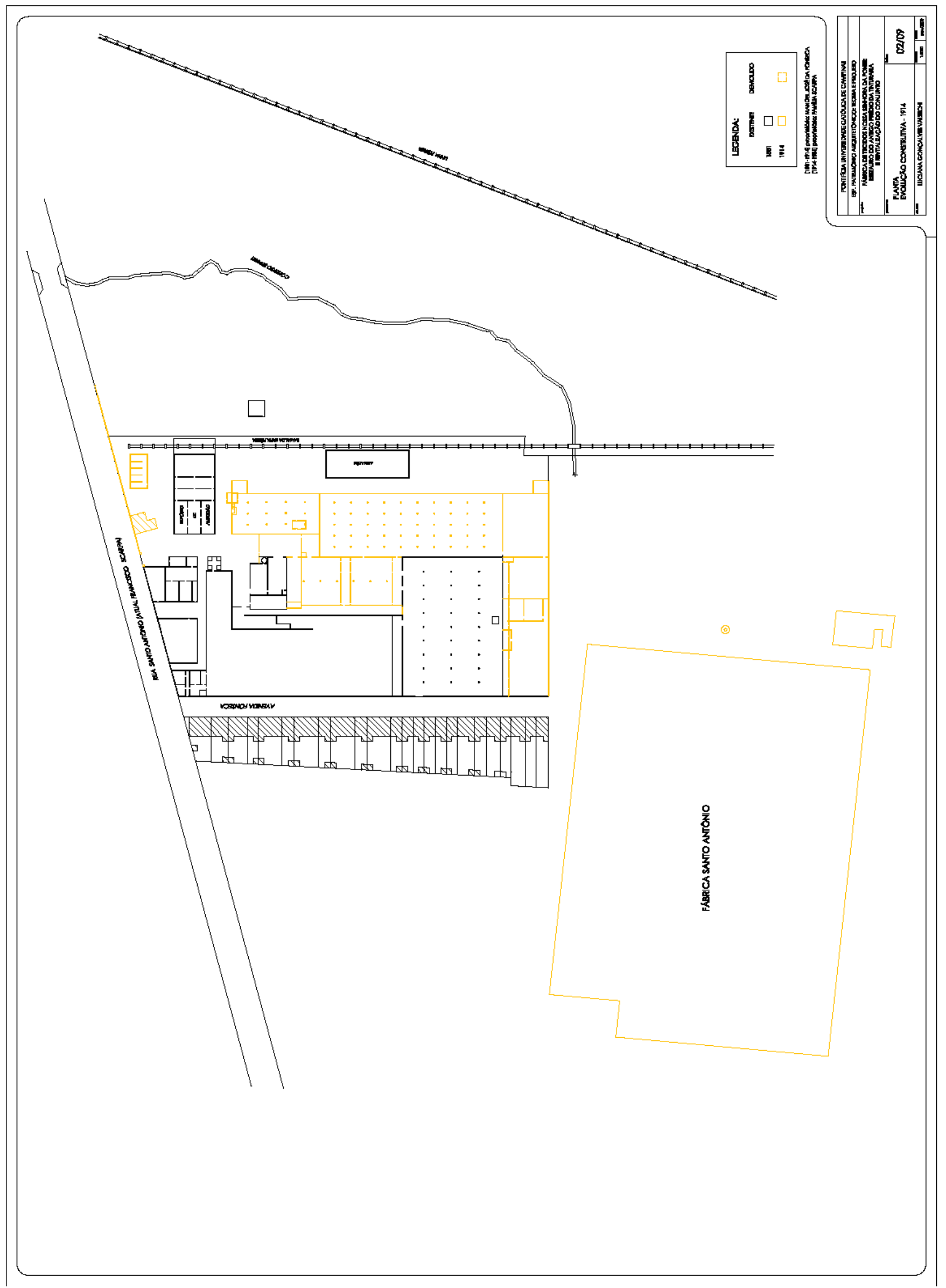

Figura 8: Fábrica Nossa Senhora da Ponte, planta - evolução construtiva 1914. Fonte: acervo Luciana G. Valsechi. 


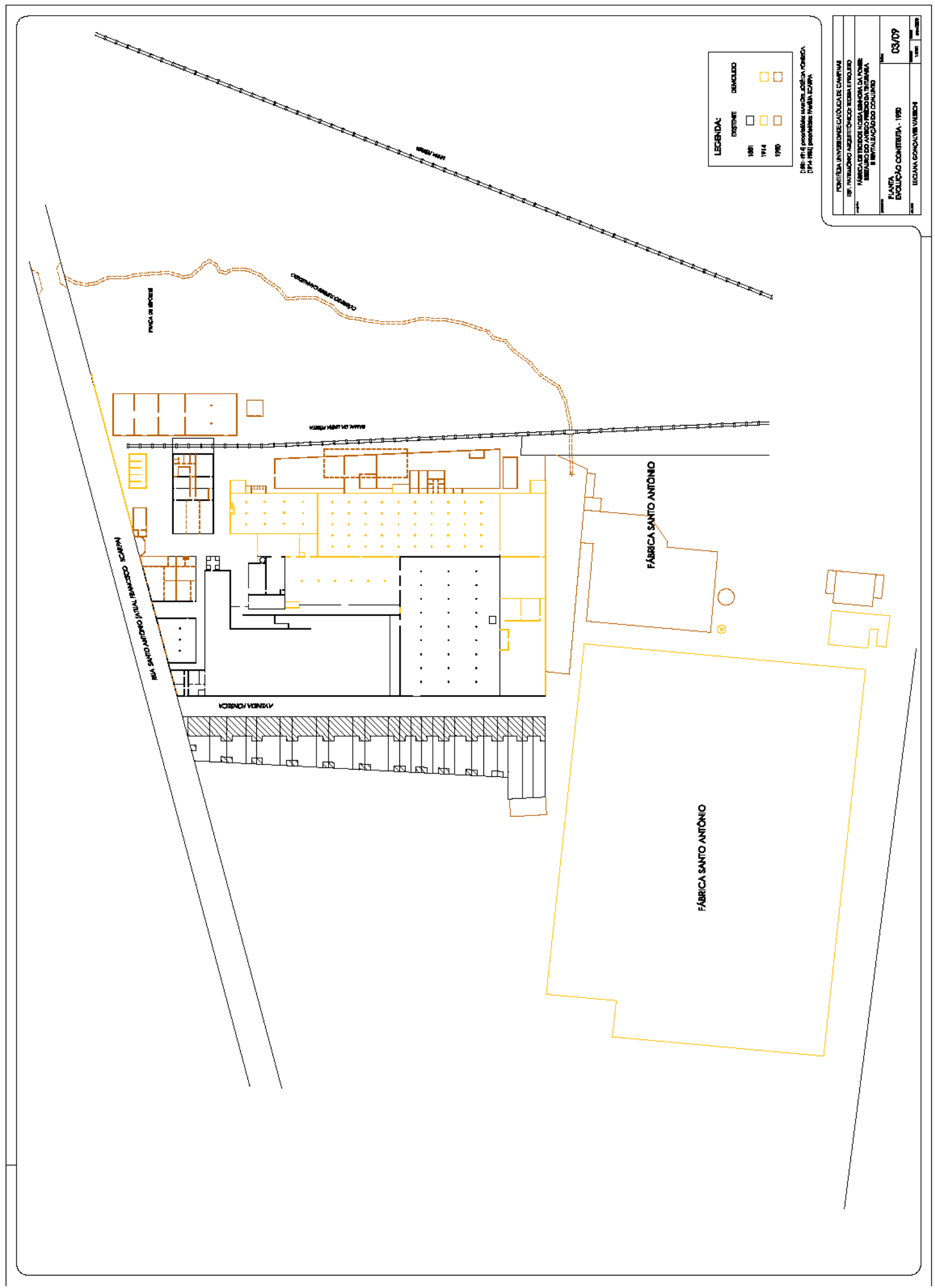

Figura 9: Fábrica Nossa Senhora da Ponte, planta - evolução construtiva 1950 (?). Fonte: acervo Luciana G. Valsechi. 


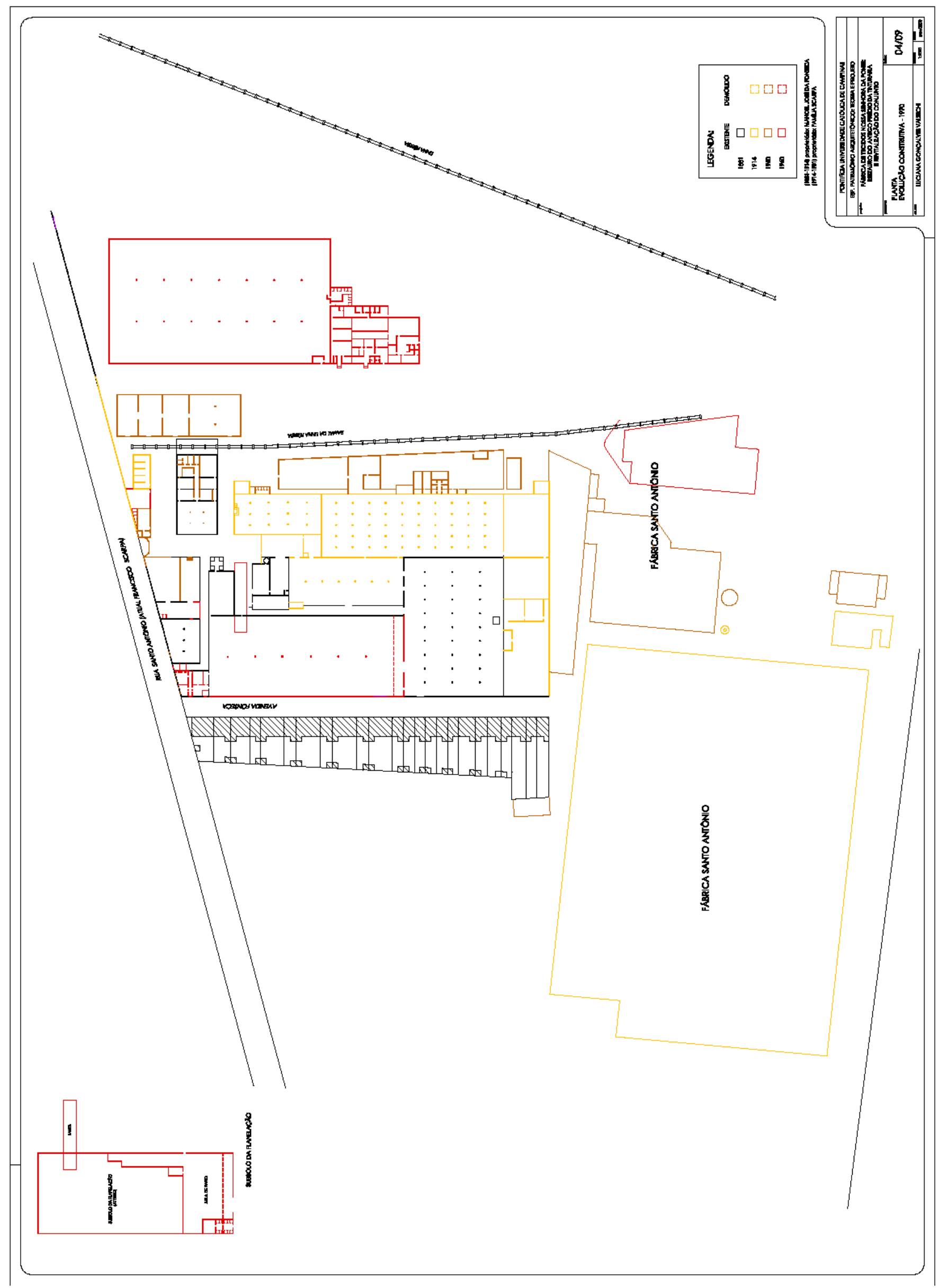

Figura 10: Fábrica Nossa Senhora da Ponte, planta - evolução construtiva 1970. Fonte: acervo Luciana G. Valsechi. 


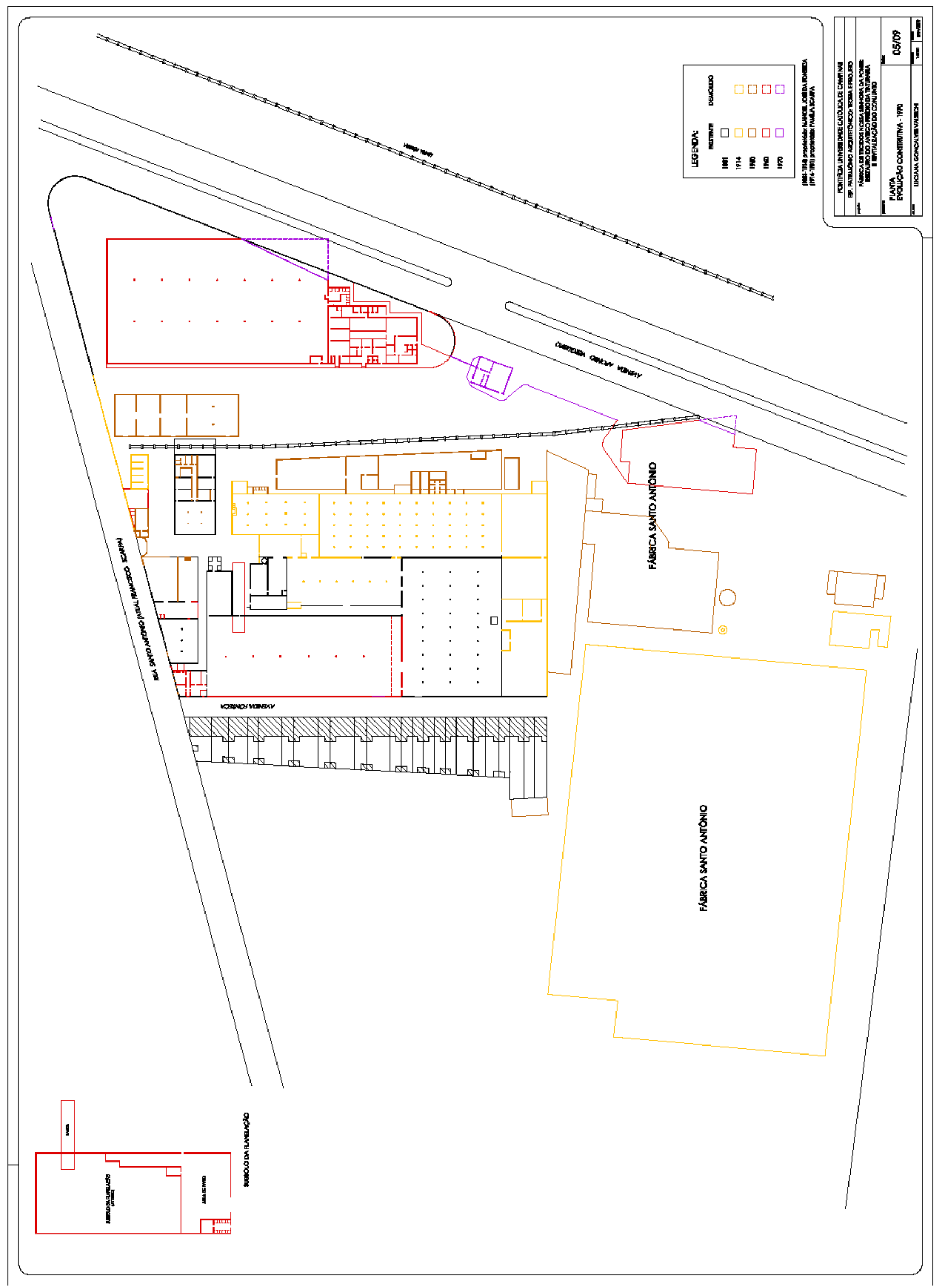

Figura 11: Fábrica Nossa Senhora da Ponte, planta - evolução construtiva 1970. Fonte: acervo Luciana G. Valsechi. 


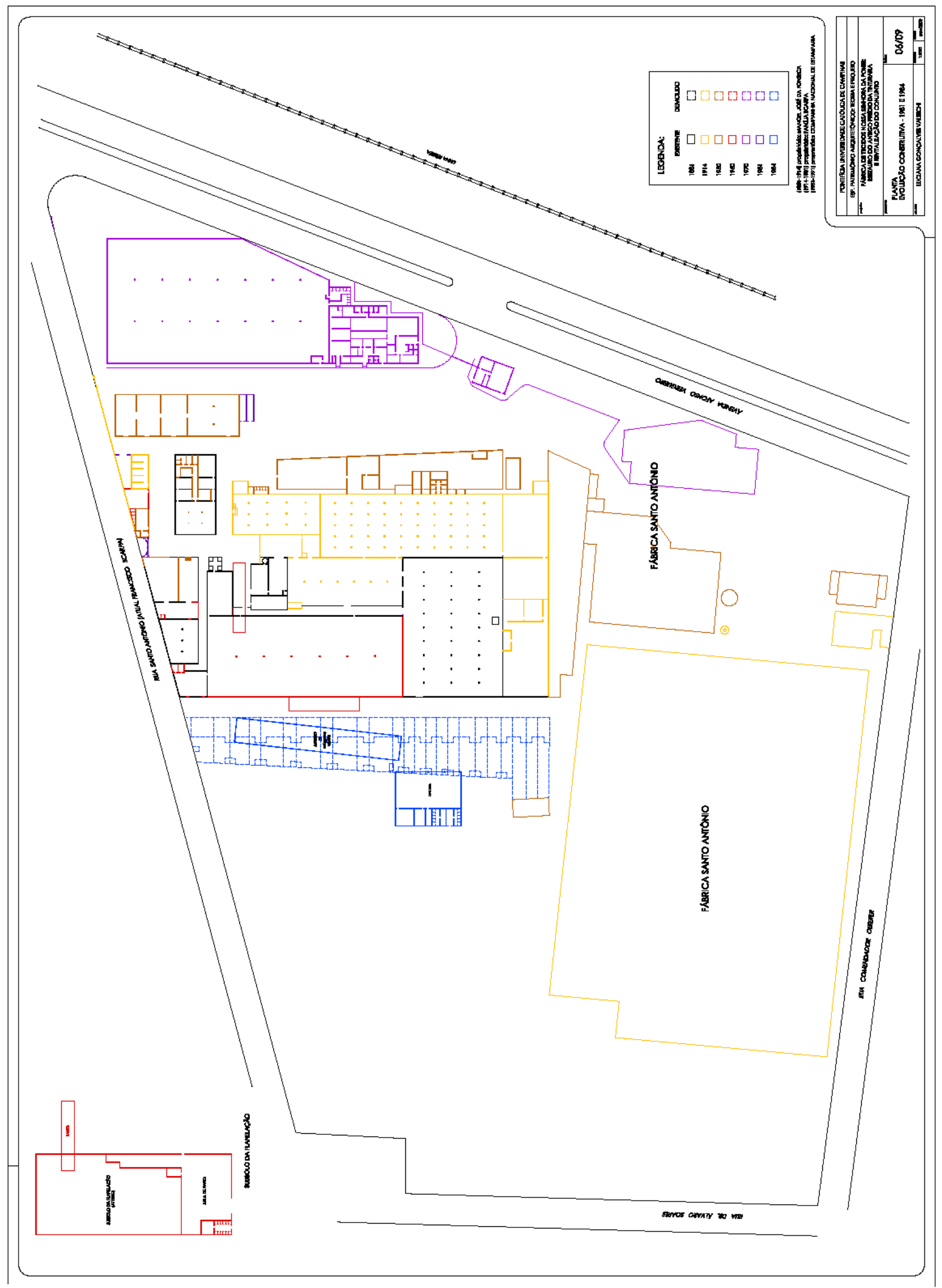

Figura 12: Fábrica Nossa Senhora da Ponte, planta - evolução construtiva 1981/84. Fonte: acervo Luciana G. Valsechi. 


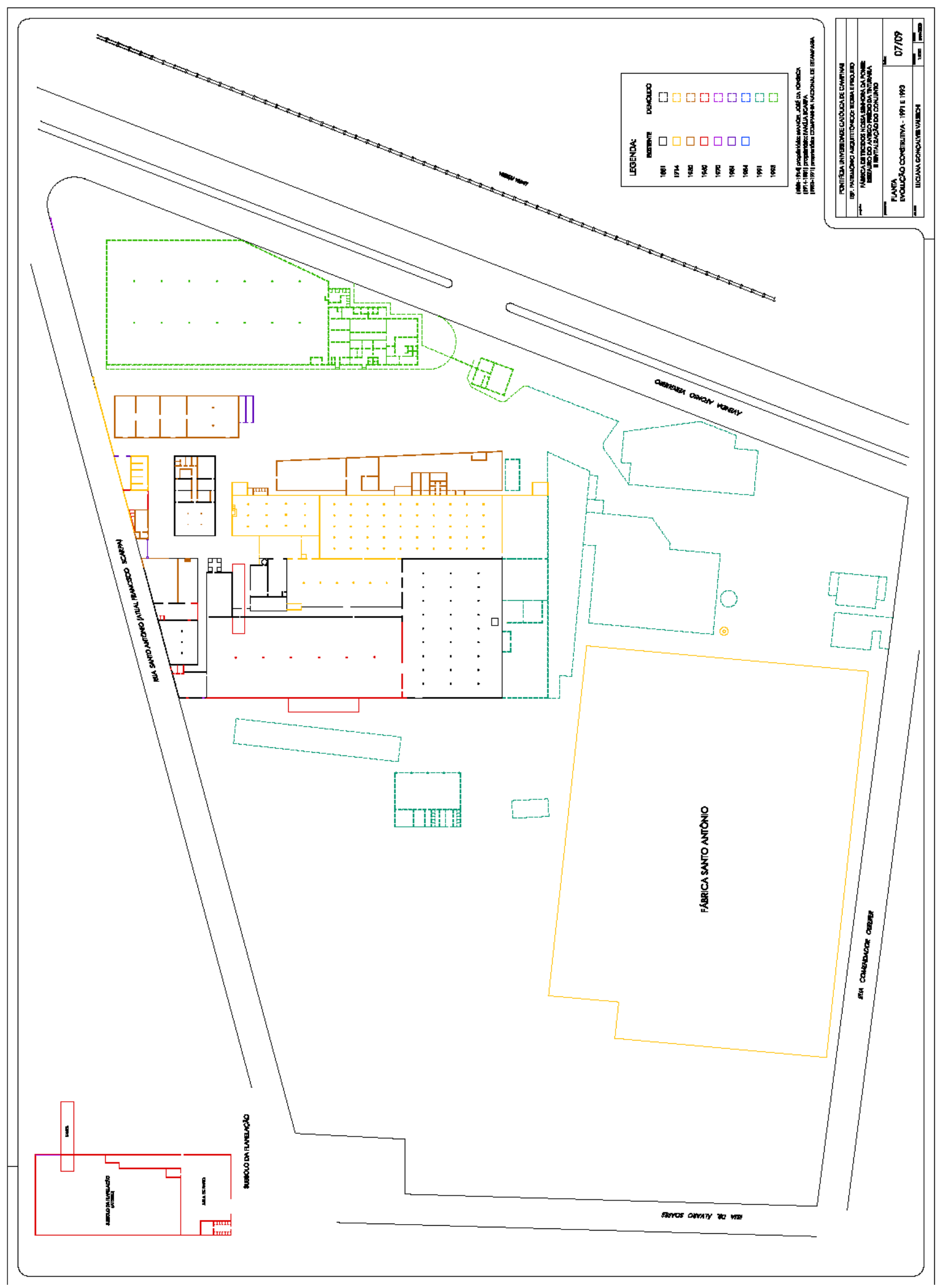

Figura 13: Fábrica Nossa Senhora da Ponte, planta - evolução construtiva 1991. Fonte: acervo Luciana G. Valsechi. 


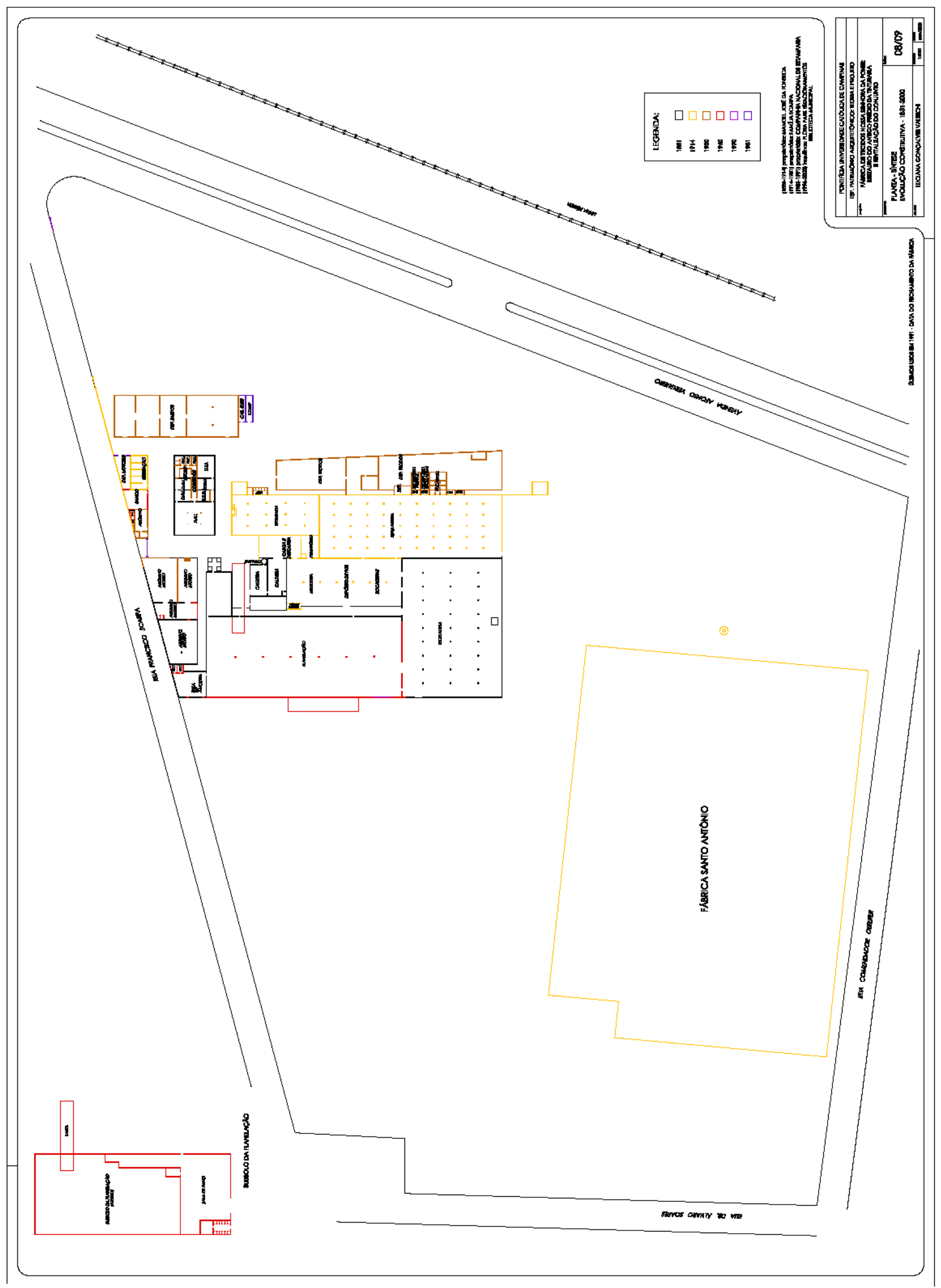

Figura 14: Fábrica Nossa Senhora da Ponte, planta - evolução construtiva 1991. Fonte: acervo Luciana G. Valsechi. 


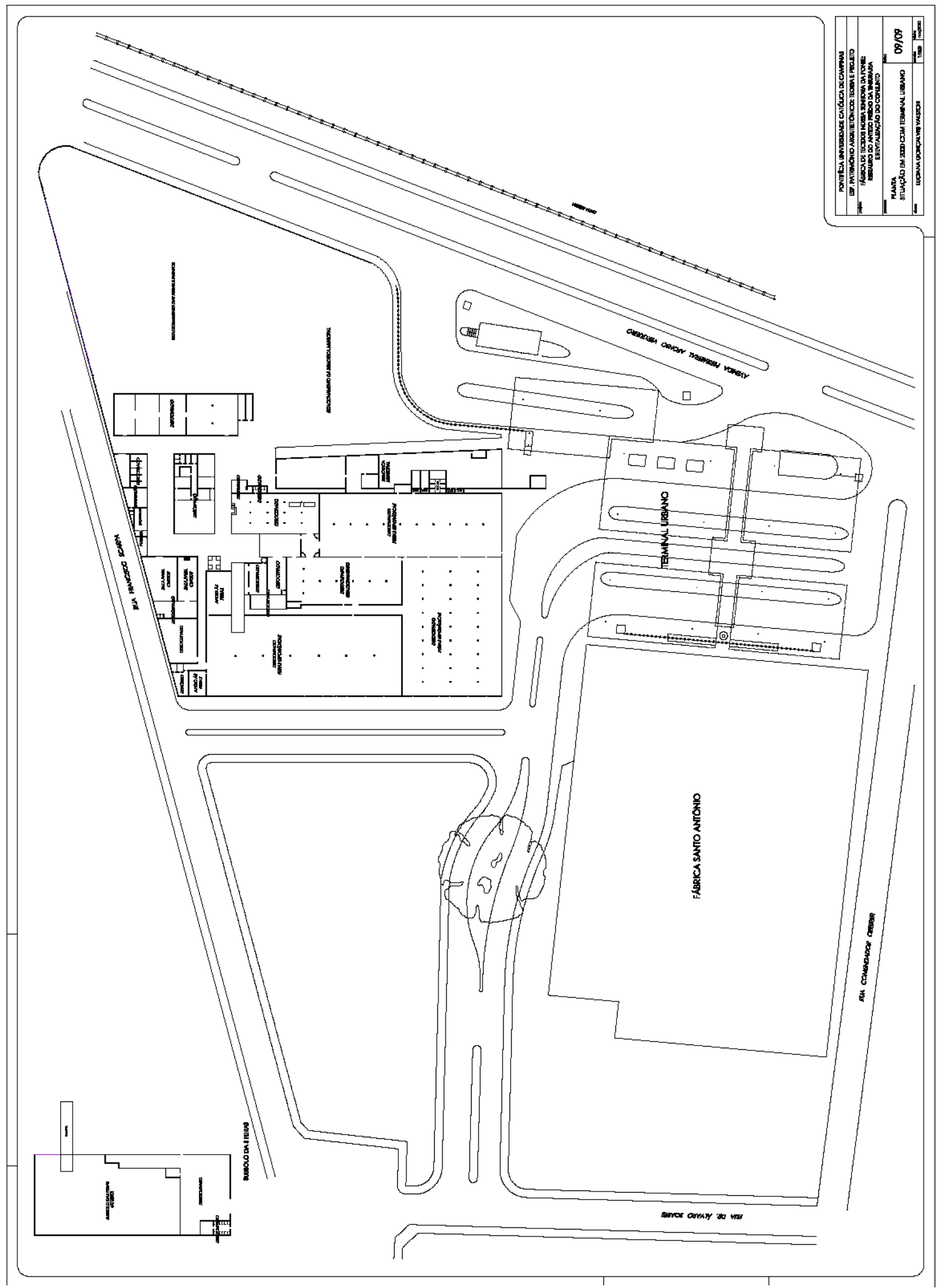

Figura 15: Fábrica Nossa Senhora da Ponte, planta - Situação atual. Fonte: acervo Luciana G. Valsechi. 
É oportuno neste momento observarmos alguns aspectos, a respeito de outros edifícios relacionados à fábrica, que serviam desde o lazer funcionários, bem como à municipalidade. São eles:

\section{Clube Scarpa}

A Associação Atlética Scarpa, ou Clube Scarpa, como era conhecido, tratava-se de um dos benefícios que passaram a fazer parte do cotidiano dos funcionários da Fábrica Nossa Senhora da Ponte, ao se tornar Companhia Fiação e Tecidos Nossa Senhora do Carmo. Em 1946, dentro das políticas de melhorias que a família Scarpa implantou na companhia, é comprado o antigo Parque Esportivo Trujillo, um clube localizado próximo à fábrica (entre a linha férrea e a atual Avenida Afonso Vergueiro), para servir de lazer aos funcionários e familiares. Este clube contava com uma estrutura composta de campo de futebol, pista de atletismo, piscinas, quadras poliesportivas, rinque de patinação, salão para eventos, vestiários, arquibancadas e etc.

Este local foi palco de inúmeros eventos esportivos importantes como os Jogos Abertos do Interior e os Jogos Operários do Estado de São Paulo. Funcionou até o início dos anos 1980, quando a Fábrica é comprada pela CNE, fazendo parte dos imóveis não fabris que seriam vendidos pela companhia. 


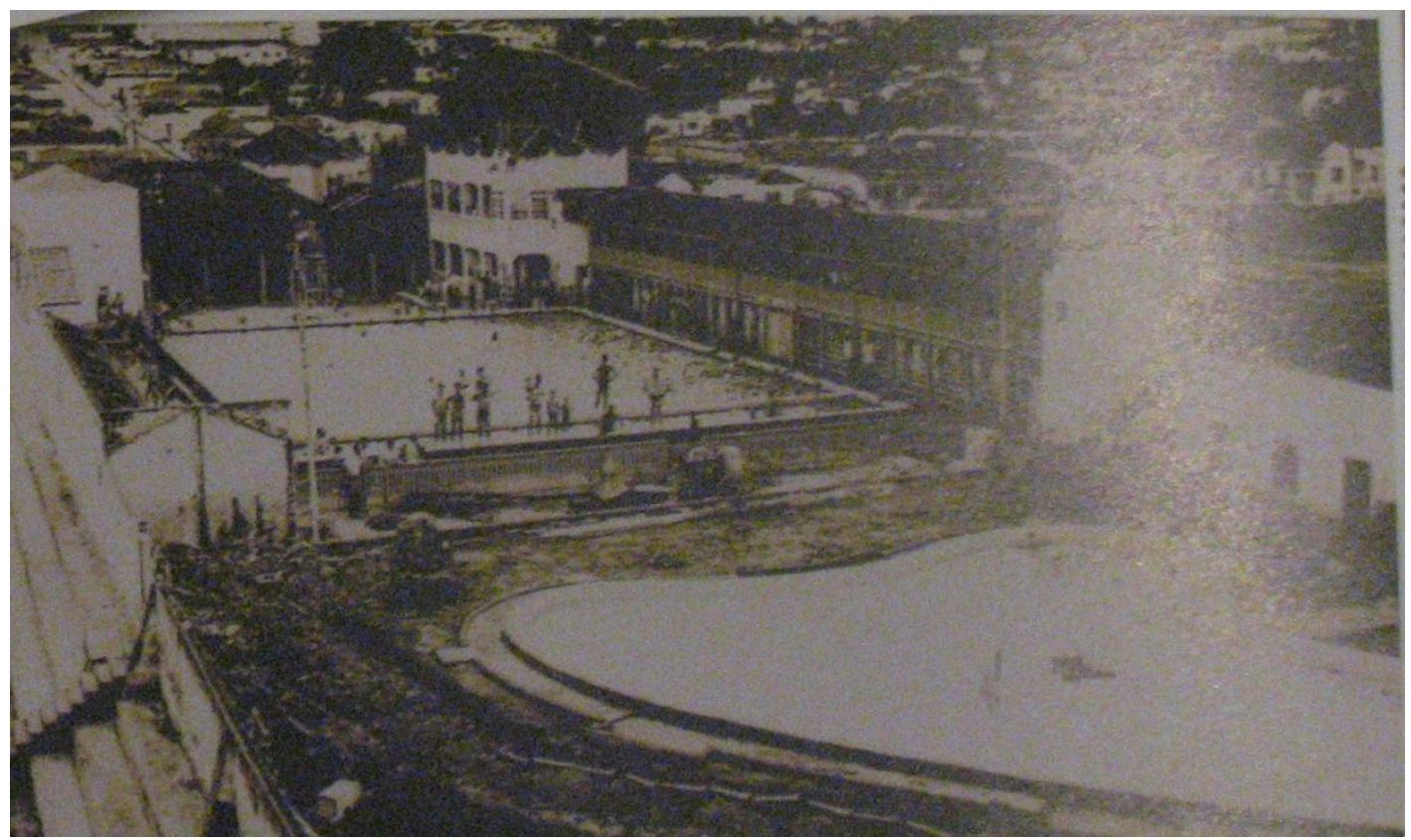

Figura 16: Clube Scarpa, balneário infantil e piscinas adultas, 1975. Fonte: WEY NETTO, Otto. Memórias do Esporte Sorocabano: 65 anos marcantes para o nosso esporte. Sorocaba, SP: do autor, 2007, p. 310.

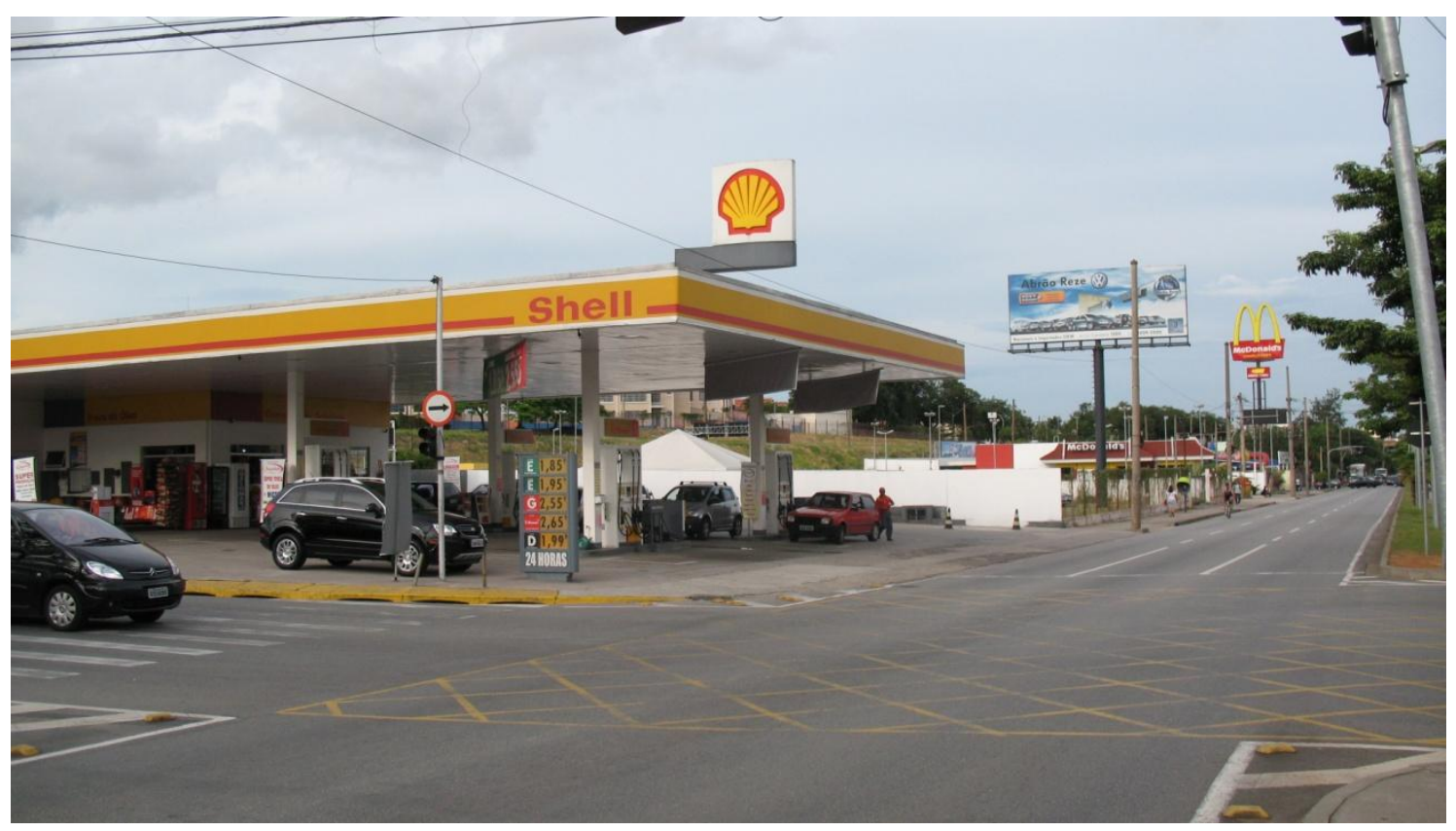

Figura 17: Avenida Afonso Vergueiro - vista para o local onde antigamente se localizava o Clube Scarpa. Fonte: do autor. 
A área foi completamente demolida e dividida em lotes menores. Em uma de suas esquinas (encontro da Avenida Afonso Vergueiro com a Rua Professor Toledo) foi implantado um posto de gasolina, existente até hoje. Em sua outra esquina (encontro da Avenida Afonso Vergueiro com a Rua Miranda Azevedo), foi construída uma grande loja de automóveis usados. A maior parcela do terreno teve diversos usos: circos itinerantes, pista para corridas de kart e atualmente abriga uma unidade de uma lanchonete (Mcdonalds) e um grande estacionamento. Toda a parte posterior do clube foi desapropriada recentemente para a construção do prolongamento da Rua Miranda Azevedo, interligando a região central da cidade com a Avenida General Osório, importante via de acesso à Zona Norte do Município. 


\section{Palacete Scarpa}

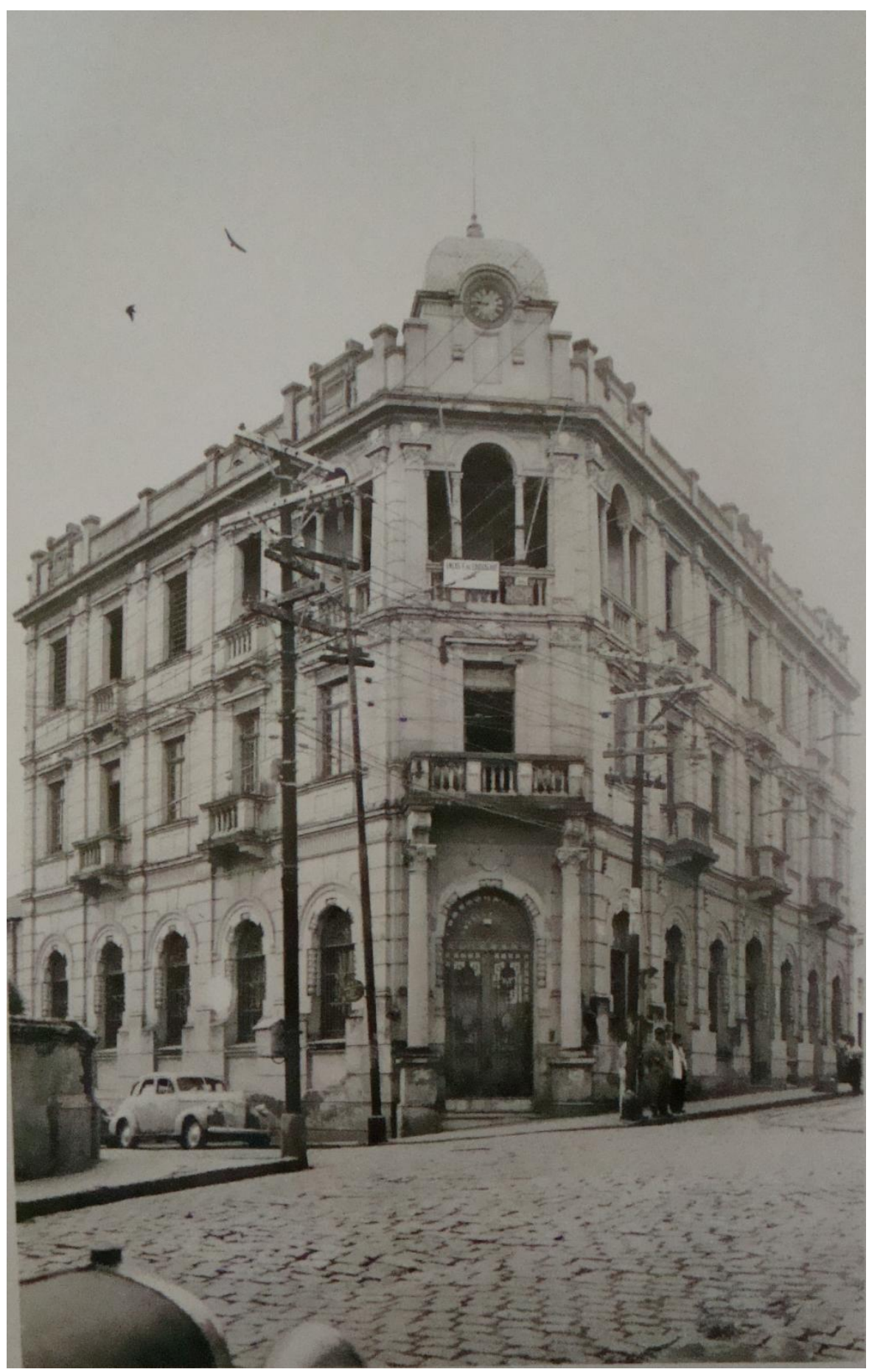

Figura 18: Palacete Scarpa, década de 1950 (?). Fonte: IHGGS.

Um dos edifícios mais importantes do centro histórico de Sorocaba, o Palacete Scarpa, edificado em 1922, é um dos raros exemplares de arquitetura eclética existentes na 
cidade. Fora construído pela S.A. Scarpa, num terreno adquirido de Dioguina Dias da Cunha ${ }^{20}$, situado na antiga Rua do Rosário (atual Rua Souza Pereira), após o rompimento da sociedade entre os Scarpa e os Pereira Inácio - onde os Scarpa ficaram com a Fábrica de Óleo Santa Helena (localizada ao lado deste terreno) e os Pereira Inácio ficaram com as indústrias Votorantim.

O projeto do palacete é de autoria dos arquitetos Marquezzini e Scapone ${ }^{21}$, sendo que sua construção ficou a cargo de um jovem chamado Chico Argentino "que naquela época era simplesmente um servente de pedreiro de apenas 18 anos" 22 . Fora construído para abrigar o Banco União, o primeiro banco de Sorocaba. Além de primeiro banco, o edifício ficou conhecido por ter sido o primeiro da cidade a possuir três pavimentos e elevador.

Pouco tempo depois de terminada sua construção, o Banco União decreta falência e o palacete fecha as suas portas. Após esse fato, o local acabou abrigando diversos outros usos: entre os anos de 1926 e 1927 passou a ser a sede do Partido Nacional Fascista de Sorocaba, Fascio Italiano; de 1932 a 1935, Hotel Pereira Inácio; em 1936 foi sede do Sindicato dos Citricultores de Sorocaba; de 1937 a 1945, posto provisório para correspondências da Companhia de Correios e Telégrafos; de 1949 até 2005, foi sede da Delegacia Regional Tributária, pasta pertencente à Secretaria da Fazenda do Estado de São Paulo ${ }^{23}$.

Durante este longo período pertencente à Secretaria da Fazenda, o edifício passou por algumas modificações, sendo que as mais divulgadas foram: a retirada do famoso elevador pantográfico (que foi doado para a prefeitura da cidade), na década de 1970 e uma reforma em 1986 (ambas melhor detalhadas na parte B desta pesquisa).

\footnotetext{
${ }^{20}$ BONADIO. Op. Cit. p. 207.

${ }^{21}$ VIVA CIDADE. Disponível em:

<http://www.vivacidade.com.br/gv pontos turisticos interno.php?id turistico=36>. Acessado em 25.01.2011.

22 SANTOS, Geovana Cybele dos. Um monumento que guarda a História. IN: Jornal Cruzeiro do Sul, 3.3.2009, caderno Turismo, p. 4.

${ }^{23}$ SANTOS, Op. Cit.
} 


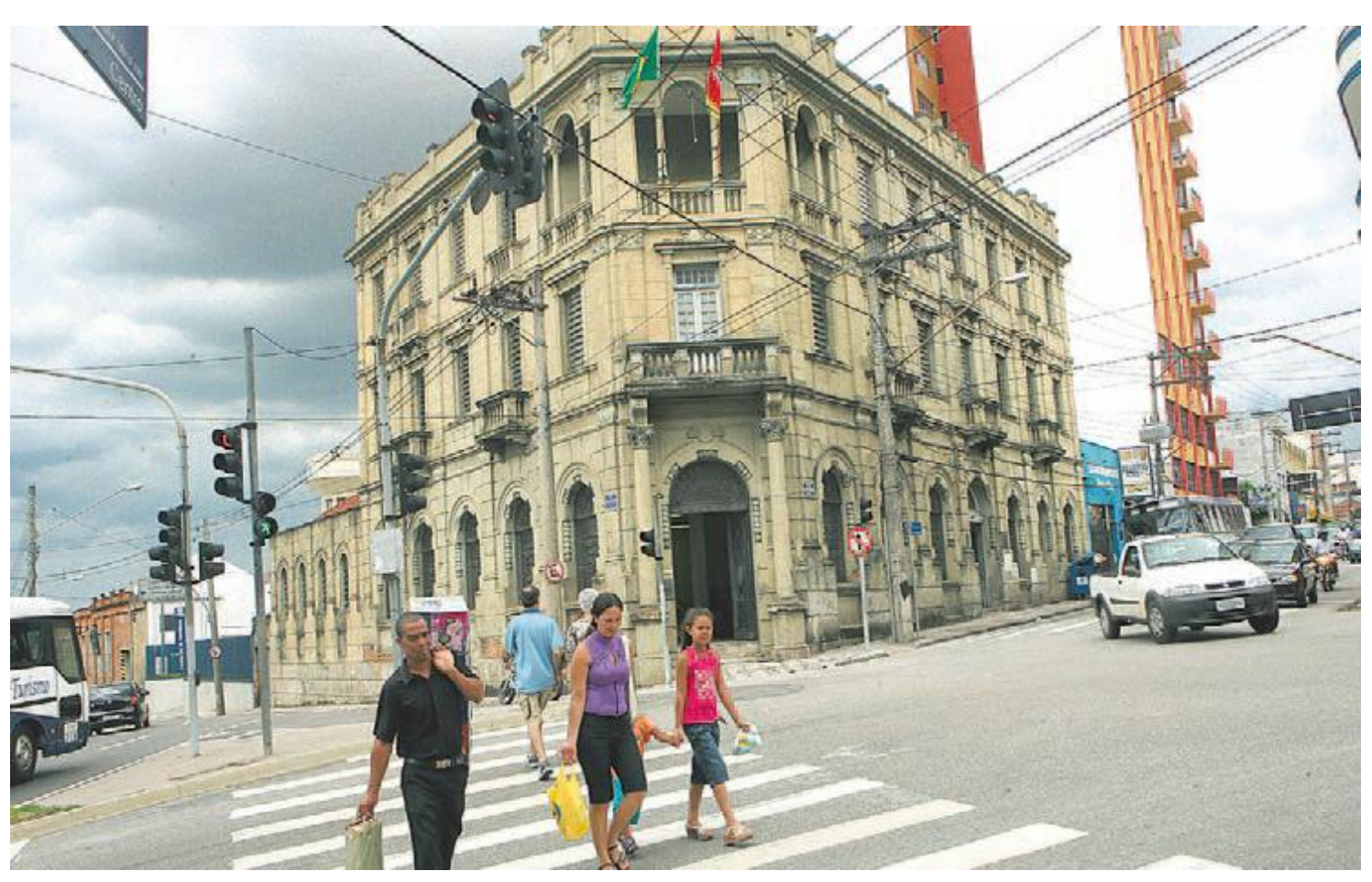

Figura 19: Palacete Scarpa, 2010. Fotografia de Adival B. Pinto. Fonte: JORNAL CRUZEIRO DO SUL, 15.12.2010, p.B-1.

Nos anos 2000, quando o estado de conservação do edifício passou a chamar a atenção da mídia local, sendo publicadas diversas matérias sobre o descaso da Secretaria da Fazenda para com o edifício, a Câmara Municipal, juntamente com o então Deputado Estadual Caldini Crespo tentaram intermediar uma solução para o caso propondo diversos usos compatíveis com o local ${ }^{24}$, a saber: reitoria da recém instalada Universidade Estadual de São Paulo - UNESP ${ }^{25}$; Fórum da Justiça Federal de Sorocaba ${ }^{26}$; e Varas Cíveis para o Tribunal de Justiça de São Paulo ${ }^{27}$. Contudo, todas estas tentativas foram frustradas.

O impasse só foi resolvido cinco anos depois pela Prefeitura Municipal de Sorocaba, que após inúmeros acordos com o Governo do Estado de São Paulo, conseguiu que o prédio fosse cedido para o poder local, em troca de outras áreas onde pudessem ser

\footnotetext{
${ }^{24} \mathrm{Na}$ época discutiu-se muito o uso que a Secretaria da Fazenda estava dando para o local, arquivo geral, considerado inapropriado para um edifício com tamanha importância para a comunidade.

25 JORNAL CRUZEIRO DO SUL, 22.4.2002, p. A-2.

${ }^{26}$ JORNAL CRUZEIRO DO SUL, 5.2.2004, p. A-2.

27 JORNAL CRUZEIRO DO SUL, 6.2.2004, p. A-5.
} 
instaladas a Delegacia Regional Tributária (DRT) de Sorocaba e o Arquivo Geral da Secretaria da Fazenda ${ }^{28}$.

Desde 2007 o prédio é sede da Secretaria Municipal da Cultura ${ }^{29}$.

Passaremos agora a relatar um apanhado histórico da Fábrica Santa Rosália e seu bairro operário, bem como outros edifícios que faziam parte deste empreendimento.

\section{A Fábrica Santa Rosália e sua aprazível vila operária}

No ano de 1890 fundam-se na cidade duas novas fábricas de tecidos, ambas distantes do centro urbano: A Votorantim - um ambicioso e diversificado projeto industrial, tendo como dono o Banco União de São Paulo, que era presidido pelo Senador Antônio Lacerda Franco e que teve como um de seus focos principais uma estamparia destinada a tingir chitas, que seriam importadas cruas da Inglaterra (atualmente situase no município de Votorantim, e não faz parte das análises feitas a seguir) - e a Santa Rosália - talvez o exemplar que mais simbolize a importância e a vanguarda das iniciativas industriais da cidade, devido a seu porte, à urbanização de seu bairro operário e aos inúmeros benefícios aos seus funcionários.

Fora construída aos moldes da arquitetura industrial inglesa - grande edifício horizontal, com fechamento em tijolos, estrutura metálica (pilares e vigas em ferro fundido), cobertura de telhas de barro em sheds, com grande número de janelas distribuídas uniformemente por todas as fachadas, porão alto em um determinado local do edifício e tendo como elementos verticais a sala de máquinas (no centro), as torres laterais e a alta chaminé. O sistema de vedação do edifício era de alvenaria de tijolos aparentes, sendo este independente da estrutura e assentados com alto grau de sofisticação. A base das paredes (as duas primeiras fiadas) foi feita em alvenaria de pedras, utilizando o aparelho regular tosco de alvenaria aparelhada. No corpo da parede fora utilizada alvenaria de tijolos, sendo aplicado o aparelho flamengo de uma

\footnotetext{
28 JORNAL CRUZEIRO DO SUL, 1.5.2006, p. A-5; 16.3.2007, p. A-5.

29 JORNAL CRUZEIRO DO SUL, 15.12.2010, p. B-1.
} 
maneira geral e o aparelho inglês somente nas paredes recuadas abaixo das janelas. Já no coroamento da fachada fora utilizado o aparelho inglês. Todas as paredes eram formadas por panos de uma vez tijolo.

Foi fundada pela sociedade formada por George Oetterer e seu genro Frank Speers. Esta sociedade foi estabelecida em 24 de outubro de $1890^{30}$ e teve como um dos grandes responsáveis, o financista Francisco de Paula Mayrink (na época presidente da Companhia Sorocaba), que garantiu os recursos necessários, pois atuou como incorporador.

Em 1898 Alfredo Moreira Pinto nos relata em sua viagem a Sorocaba os seguintes aspectos sobre a Fábrica Santa Rosália:

"Esta fabrica, de propriedade do Sr. Francisco de Paula Mayrink, está situada em um plateau e accupa um vasto edificio, á margem do rio Sorocaba e da estrada de ferro Sorocabana, apouco mais de um kilometro da cidade e com a frente voltada para o nascente.

Tem o edificio 201 metros de frente e 150 de fundos.

Dispõe de diversas officinas, entre as quaes uma para concertar os objetos da fabrica, uma com um dynamo da força de 25 cavallos e que serve para tocar a bomba electrica que conduz a agua do rio para um grande tanque, com tres e meio metros de profundidade e existente na frente da fabrica, sendo a differená do nivel entre o rio e o tanque de 28 pés inglezes.

Move a fabrica um motor de 650 cavallos, devendo, quando a fabrica contiver mil teares, para o que já se acha apparelhada com todos os elementos, ter uma força de 1.300 cavallos.

A fabrica de fiação funcciona á direita do edificio.

O algodão, recebido em fardos, é conduzido para o picador e depois levado para os batedores, de onde passa para as cardas.

É maravilhoso o mecanismo das cardas. Recebe o algodão em rolo, o qual entra para um callender transformado

\footnotetext{
${ }^{30}$ Assinaram a ata da fundação a 24 de Outubro de 1890, entre outros o Dr. Manoel Rodrigues Monteiro de Azevedo, Cel. João Alfredo de Athayde, Francisco José Speers (Frank Speers), George Oetterer, Joaquim Catramby, José Ricardo Augusto Leal, José Duarte Rodrigues, Dr. Antonio José Ferreira Braga. A sua primeira diretoria era composta pelo Comendador George Oetterer, presidente; Dr. Antonio José Ferreira Braga, secretário; Dr. Manoel Rodrigues Monteiro de Azevedo, Dr. Ludgero Antonio Coelho, Comendador José Ricardo Augusto Leal e Dr. Eugênio Ferreira de Andrade, conselheiros Fiscais; Conselheiro Francisco de Paula Mayrink, Comendador João Leopoldo Modesto Leal, Coronel João Alfredo de Athayde e Dr. Joaquim Catramby, suplentes.
} 
Transformado em fios tão tênues, que parecem flocos de neve. Do callender sahe um fio para as puxadas, que preparam o algodão, dando-Ihe maior consistencia; dahi passa para diversas machinas com carreteis que vão tornando o algodão cada vez mais fino; depois para machinas continuas, depois para a urdidura, para o engommador $e$ dahi finalmente para os teares.

A fabrica acha-se perfeitamente montada com os mais aperfeiçoados machinismos $e$ deve, quando ficar concluída, ser uma das primeiras do Brazil".

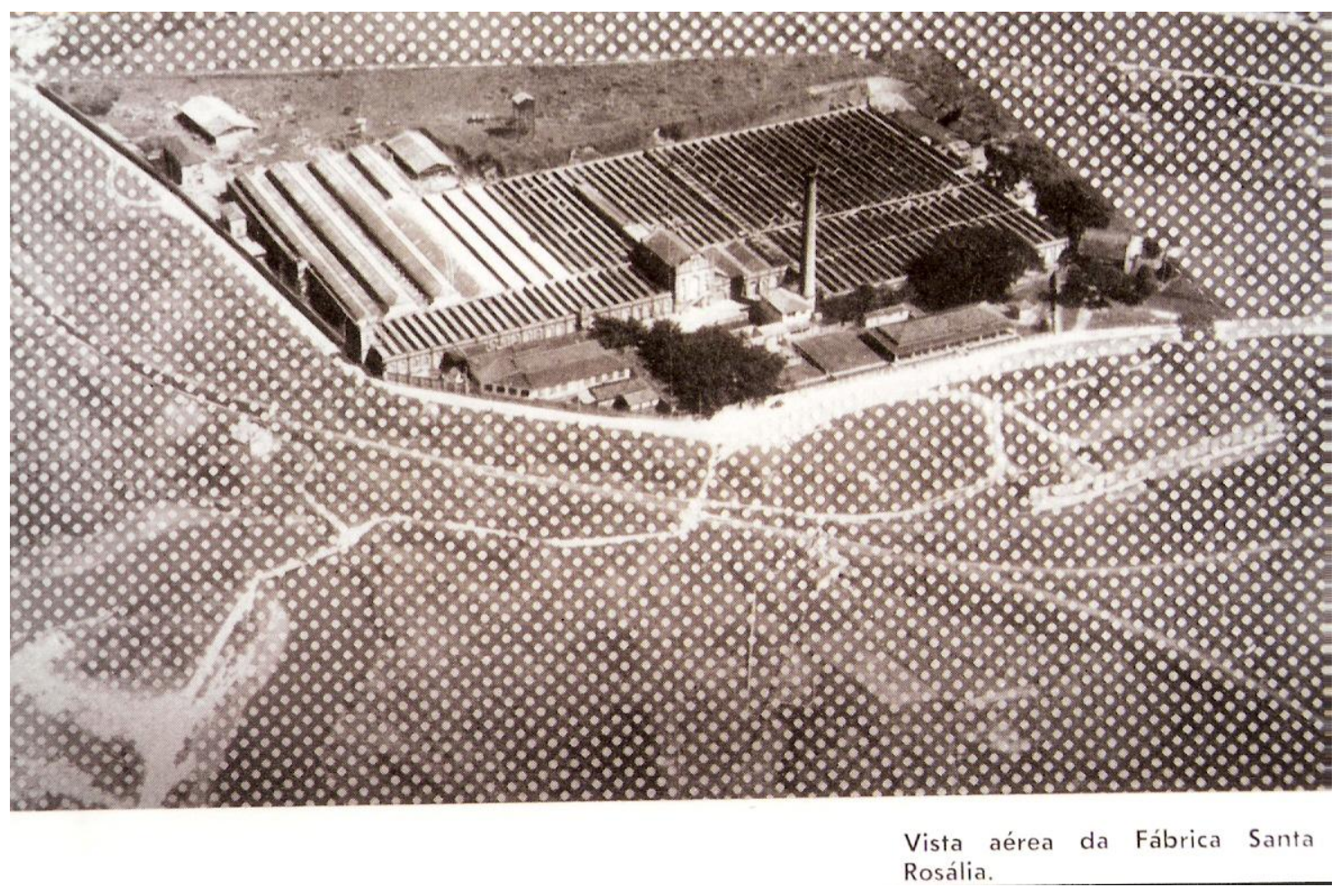

Figura 20: Fábrica Santa Rosália, aerofotografia, 1959. Fonte: Cia. Nacional de Estamparia - 50ㅇ Aniversário, Sorocaba. Magazine das Nações. Ano 12 - Edição Especial. Editora e Publicidade Roman Ltda., São Paulo, Maio de 1960. Acervo do autor.

Nascido em 1841 na cidade de Gotha, região da Turíngia, Alemanha, George Oetterer vem para o Brasil em 1860 para trabalhar na companhia São Paulo Railway durante construção da Estrada de Ferro Santos-Jundiaí, uma vez que sua formação acadêmica era de administrador ferroviário. Em 1874 é convidado por Matheus Maylasky a se tornar administrador do Projeto de implantação da Estrada de Ferro Sorocabana. Em 1890 após ter cumprido seus serviços na EFS, desliga-se da ferrovia e associa-se a Frank Speers, companheiro de trabalho que conheceu na SPR e que se tornou seu 
genro. Portanto, desta associação e dos capitais fornecidos por Mayrink é que foi possível a construção da Fábrica Santa Rosália.

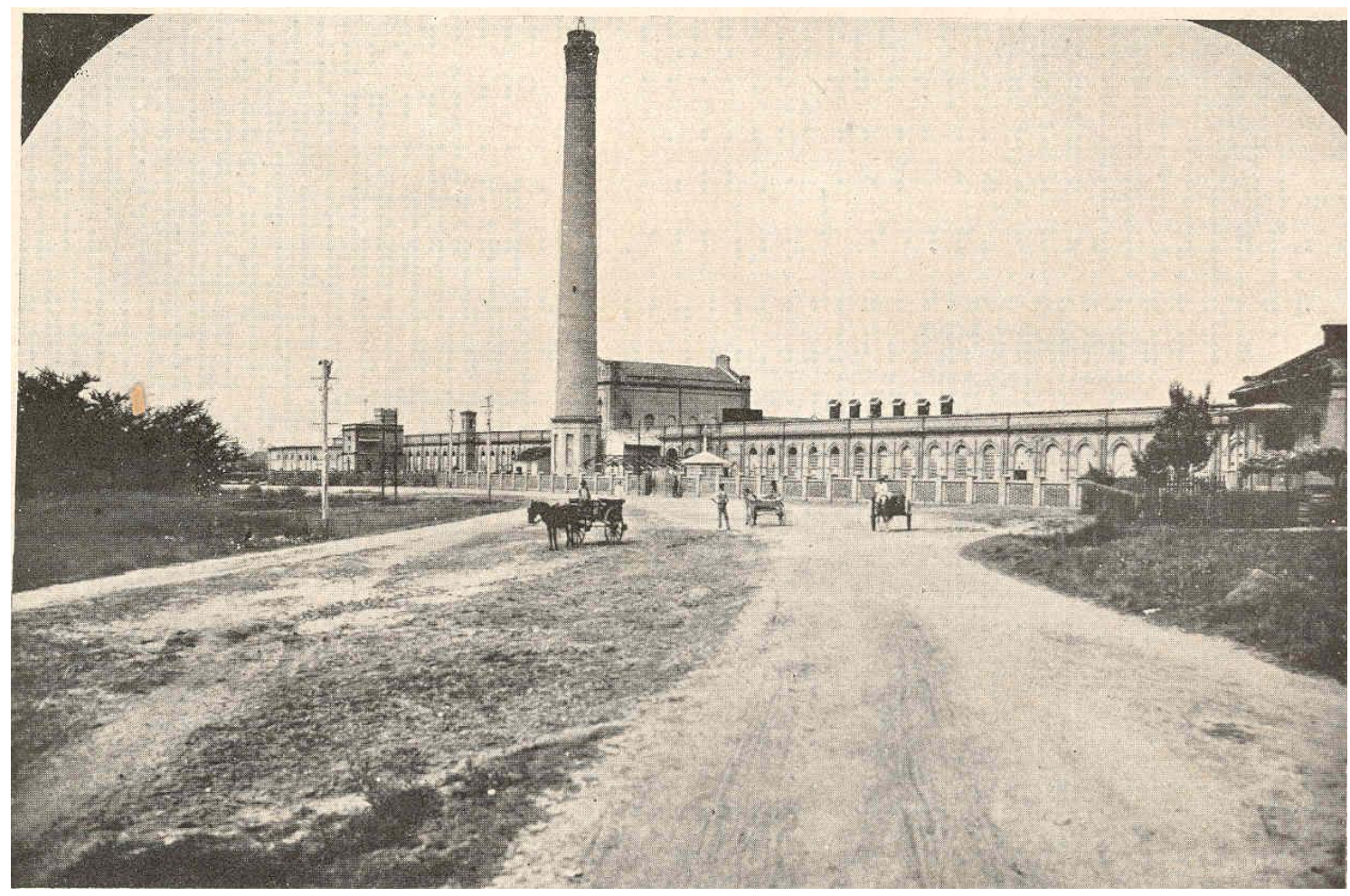

Figura 21: Vista frontal da Fábrica Santa Rosália. Fonte: Museu Histórico Sorocabano

Foi casado com Ana Cândido Malheiro, com quem teve três filhos: Carlos Augusto Malheiro Oetterer, Maria Rosália Oetterer (que se casou com Frank Speers) e Amélia Oetterer.

"O nome da fábrica (da qual se originou o do bairro), segundo familiares dos fundadores, foi uma homenagem à mãe de George Oetterer-Rosália, descendente dos barões Von Poescsh. Há quem diga que quem foi homenageada foi Maria Rosália Oetterer Speers, filha de George e mulher de Frank Speers" ${ }^{31}$.

\footnotetext{
${ }^{31}$ MASSARI, Marco Antônio Leite; MEDRANO, Ricardo Hernàn. Arquitetura Industrial e Inserção Urbana: o Caso da Fábrica Santa Rosália em Sorocaba. In: IV Coloquio Latinoamericano e Internacional sobre
} 
O terreno onde a fábrica foi implantada fazia parte de uma grande fazenda, com 44 alqueires $\left(1.064 .800 \mathrm{~m}^{2}\right)$, tendo como limite o Rio Sorocaba e os terrenos da EFS. Assim como as outras fábricas de Sorocaba, sua escolha deveu-se aos mesmos três fatores: proximidade a um curso d'água, terreno com boa topografia e a possibilidade de ter um ramal da EFS.

A administração de Oetterer e Speers foi eficiente. A direção da fábrica só começou a passar por momentos difíceis quando falece o único filho homem de George - Carlos Malheiros Oetterer - que seria o futuro administrador. Ambos em idades avançadas são obrigados a passar a direção da fábrica a Jorge Mário Speers, sobrinho de George, que se revelou um profissional não eficiente. Devido a isso, a família perde o controle da indústria para a CNE - Companhia Nacional de Estamparia ${ }^{32}$. Pouco tempo após este episódio, George Oetterer falece. Sua morte foi documentada no Jornal Cruzeiro do Sul em 5 de outubro de 1907:

"Victimado por uma grave e pertinaz enfermidade que zombou de todos os recursos da sciencia medica, falleceu hontem às 4 e poucos minutos da tarde o venerando ancião Sr. Commendador Jorge Oetterer, socio da importante fabrica de tecidos 'Santa Rosália', desta cidade.

A triste nova, conquanto esperada, tal a gravidade da molestia que minara aquella existencia precios, causou a mais viva consternação nesta cidade, onde o querido morto gozava de geraes amisades tal o seu caracter de homem probo e honesto e o seu coração sinceramente philantropico.

O commendador Jorge Oetterer contava 66 anos de idade; de nacionalidade alleman adoptou o Brasil como sua patria, naturalisando-se brasileiro e aqui prestando innumeros e inolvidaveis serviços, já como alto funccionario de principaes Estradas de Ferro, inclusive a Sorocabana, da qual foi zeloso superintendente por longo espaço de tempo jà como industrial de grande tino. Deixa tres filhos: o estimado moço Sr. Carlos Oetterer, a distincta senhorita Amelia Oetterer e a exma. Sra. D. Maria Rosália Oetterer Spiers, digna esposa do Sr. Frank J. Spiers, tambem sócios da fabrica 'Santa Rosália'.

O enterro está marcado para hoje às 5 horas da tarde, sahindo o feretro da chacara de residencia do fallecido, nesta cidade.

Rescate y Preservación del Patrimonio Industrial, 2007, Buenos Aires. IV Coloquio Latinoamericano e Internacional sobre Rescate y Preservación del Patrimonio Industrial. Buenos Aires: Cedodal, 2007.

${ }^{32}$ Antes da fábrica se tornar propriedade da CNE, a Santa Rosália converte-se à Fábrica de Tecidos Santa Rosália S. A. como um recurso dos antigos donos para não a perderem. Porém, a CNE adquire a maior parte das ações e designa Bráulio Guedes e Hélio Manzoni para dirigirem a fábrica que, por sua vez, suspendem o pagamento de dividendos e obrigam os proprietários originais a, pouco a pouco, venderem o resto das ações. 
$A^{\prime}$ distincta família, tão rudemente ferida pelo golpe impiedoso do Destino inplacavel, apresentamos as expressões do nosso profundo pesar" ${ }^{33}$.

Durante a administração Oetterer \& Speers começou-se a moldar o bairro com a construção de inúmeros equipamentos para os funcionários. Dentre eles destaca-se a vila que era formada por 250 pequenas casas distribuídas em três ruas (São Francisco, Santana e Zico) e uma pequena praça (Praça São Carlos). Em frente a essas casas - que não possuíam sistema de iluminação, nem rede de esgotos, apenas água encanada ficava um grande tanque d'água para lavar roupas (Rua São Francisco). Todas essas ruas que formavam essa vila, juntamente com todo complexo eram de terra batida.

Os diretores da fábrica, que eram ingleses, moravam em três casas em frente à fábrica. Um desses ingleses, Mr. Klirck, amigo particular de Charles Miller (responsável por trazer o futebol ao Brasil), tornou-se popular entre os operários por tentar introduzir jogos de futebol nas horas de lazer dos funcionários. Num campo de futebol, improvisado e próximo à vila, foi fundada a agremiação Fortaleza Club. Seu nome deve-se à visita que Mr. Klirck fez ao Ceará, tendo voltado encantado com as belezas naturais daquele estado. Isto ocorreu em 1903. Este mesmo campo tornou-se mais tarde, na década de 20, o jardim de Santa Rosália (Praça São Carlos).

É interessante relatar que o escritor Jacob Penteado (Prêmio Jabuti 1963, pelo livro “Belenzinho 1910", reeditado há pouco tempo ${ }^{34}$ ) dedicou um capítulo deste seu livro inteiramente à vida operária que seus pais e ele levavam em Santa Rosália, no início do século XX. O referido capítulo chama-se "Na Velha Sorocaba".

No Almanaque Ilustrado de Sorocaba, de 1914, mais precisamente no artigo "Sorocaba Industrial" consta um grande relato sobre a fundação e prosperidade da Fábrica Santa Rosália, e sobre todos os benefícios que os funcionários possuíam, tais como: uma banda musical, escola, consultório médico, casa de diversões (?) e um armazém.

\footnotetext{
33 JORNAL CRUZEIRO DO SUL, 5.10.1907, p.1.

${ }^{34}$ PENTEADO, Jacob. Belènzinho, 1910 (retrato de uma Época). 2a Ed. São Paulo: Carrenho/Narrativa Um, 2003, pp.13-20.
} 
Cabe salientar que dos diretores proprietários, Oetterer morava longe dali, mais precisamente numa fazenda vizinha à já desativada Fábrica Real de Ferro de São João Ypanema (hoje pertencente ao Município de Iperó). A sede desta fazenda, uma belíssima casa, permanece até os dias atuais sob posse de seus descendentes. Boa parte de sua propriedade, no entanto, foi paulatinamente sendo invadida e originou o bairro George Oeterer.

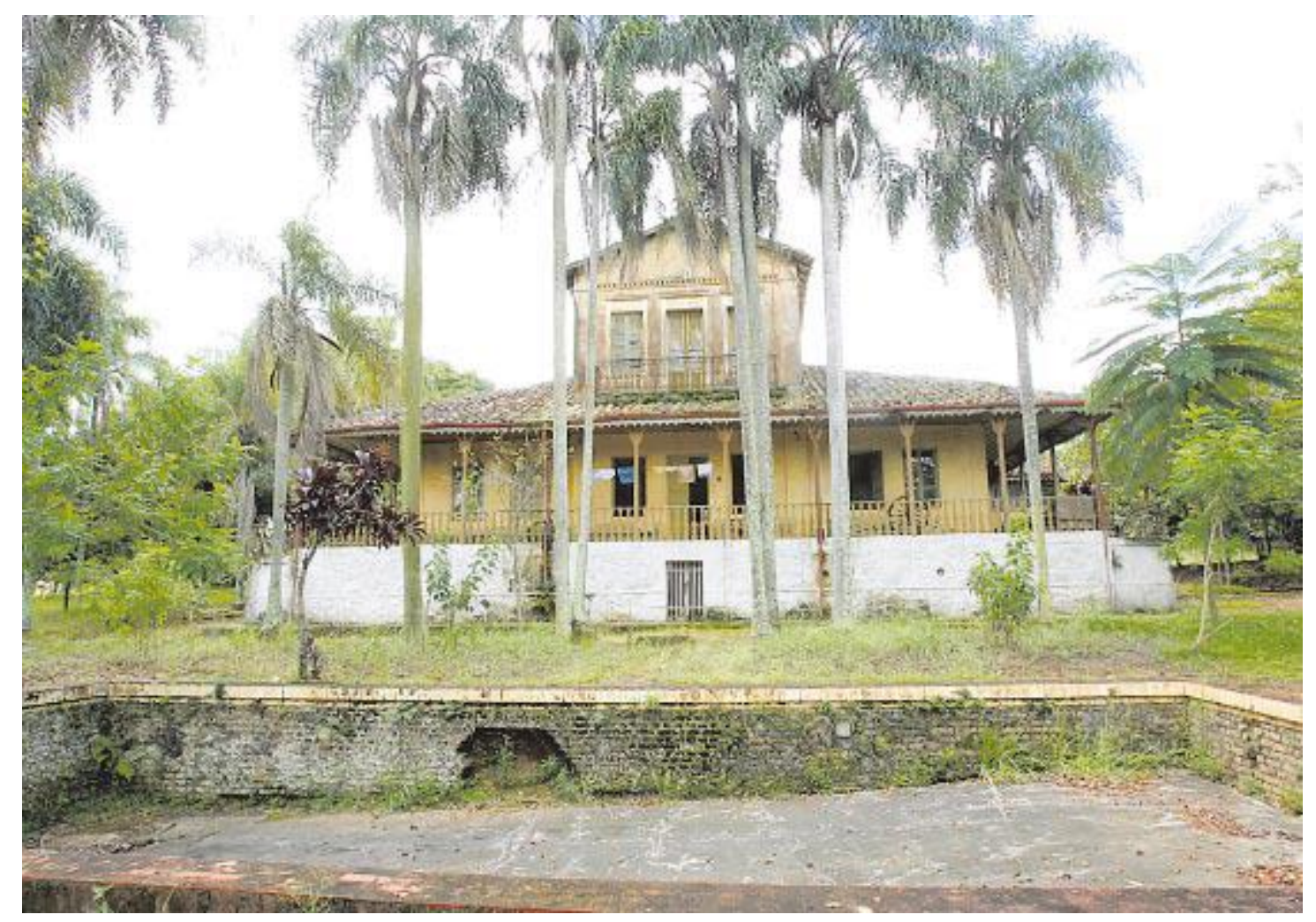

Figura 22: Casarão de George Oetterer, Iperó, São Paulo. Fonte: ADIVAL B. PINTO, Jornal Cruzeiro do Sul, 22 de Abril de 2009, p. A1. 


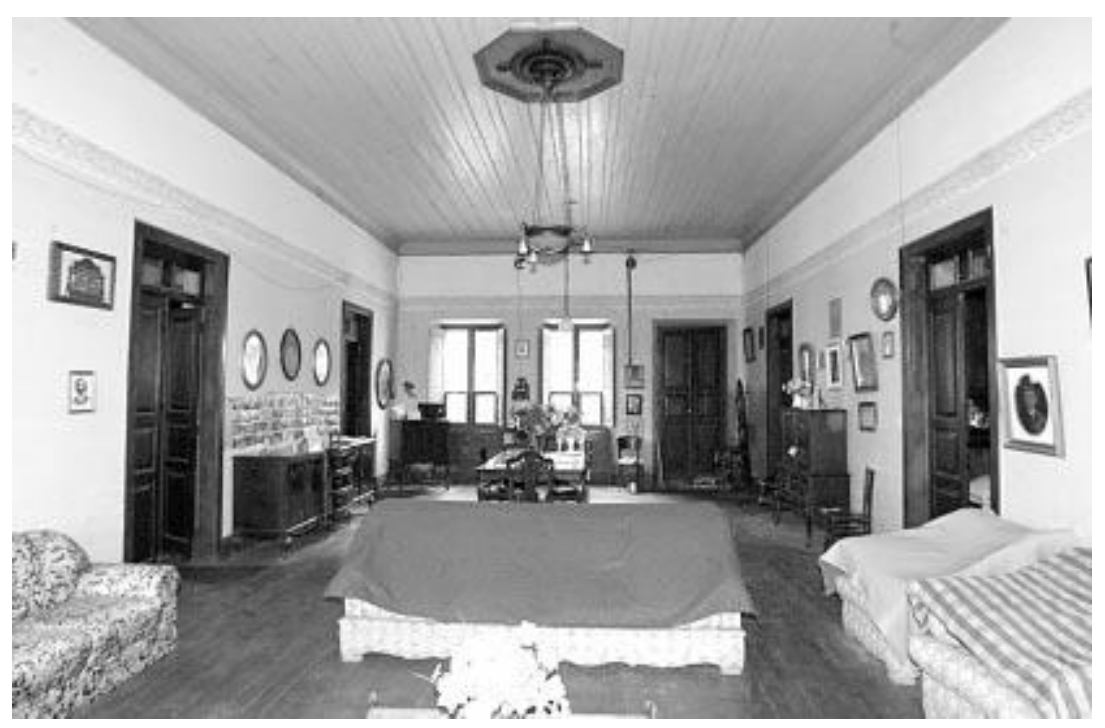

Figura 23: Parte interna da casa ainda conserva a mobília antiga, de madeira maciça e pinturas nas paredes. Fonte: ADIVAL B. PINTO, Jornal Cruzeiro do Sul, 22 de Abril de 2009, p. A9.

\section{A Vila Operária de Santa Rosália}

Após a construção da fábrica, os empreendedores George Oetterer e Frank Speers idealizaram a construção de uma vila operária para os funcionários que pudesse ser independente do núcleo urbano de Sorocaba. Com isso iniciaram a construção de casas e demais elementos que fossem necessários para a vida dessas pessoas. De acordo com o Almanach Illustrado de Sorocaba de 1914,

"a villa...é organisada de 270 casas, escolas públicas, consultório medico, armazém, casa de diversões, etc.,sendo magnífica a sua illuminação elétrica e perfeito o serviço de encanamento de água.

A energia electrica para a illuminação da Villa, bem como para a movimentação da fabrica, que possúe 11 motores com um total de 1.230 H.P., fornecida pela São Paulo Electric Company.

Notando o incremento constante da industria sorocabana, especialmente exemplificada no progresso da fabrica Santa Rosália, o proprietário de um terreno magnificamente situado entre a cidade e aquelle estabelecimento vendou-o em lotes, traçando nelle a planta de mais uma grande villa operaria.

Esta villa será servida por uma linha de bondes do contracto Rankin, que attingirá também a fabrica Santa Rosália. 
A linha da Sorocabana Railway atravessa os terrenos da sociedade em commandita Oetterer, Speers \& Companhia, deixando isolado da fabrica o edificio do aspirador hydraulico.

Aquella companhia cedeu aos proprietarios da fabrica Santa Rosália uma chave com desvio facilitando desse modo o serviço de embarque de mercadorias" ${ }^{35}$.

Cabe ressaltar que apesar do almanaque citar que as casas possuíam água encanada, nem todas eram dotadas desse serviço, como podemos observar nas casas da Rua São Francisco, que, para suprir esta necessidade, contavam com um grande tanque no canteiro central da via para os moradores se abastecerem. Contudo, é indispensável citar que este sistema de abastecimento foi o primeiro encanamento que a cidade possuiu.

Interessante também frisar que nenhuma casa ou estabelecimento contava com coleta de esgoto ou banheiro dentro da residência. Possuíam apenas uma "casinha" ${ }^{36}$ no quintal das casas onde era possível utilizar de uma fossa para as necessidades fisiológicas e também para tomar banho. Apesar de a vila possuir iluminação elétrica, as casas não possuíam luz elétrica.

As poucas ruas da vila, assim como a cidade de Sorocaba, não possuíam pavimentação. As ruas da primeira Vila de Santa Rosália eram: Rua São Francisco (a rua principal e que atualmente corresponde à Avenida São Francisco), Rua Santana (paralela à principal e que ainda mantém hoje a mesma nomenclatura) e Rua do Zico (transversal à principal e que também mantém ainda a mesma nomenclatura), além da Praça São Carlos (atual Praça Pio XII). Apesar de a vila ser pequena, o terreno de propriedade da fábrica era enorme, aproximadamente 44 alqueires (citado anteriormente), o que equivaleria ao seguinte perímetro nos dias atuais: ponto 1 - esquina da Alameda Kenworthy com a Rua Aparecida; ponto 2 - esquina da Rua Aparecida com a Rua Ângelo Elias; ponto 3 esquina da Rua Ângelo Elias com a Rua Ana Monteiro de Carvalho; ponto 4 - esquina

\footnotetext{
35 CUNTO, João de. "A Indústria em Sorocaba”, In: WERNECK, Bráulio (Org.) Almanach Illustrado de Sorocaba. Repositório histórico, literário e recreativo com ilustrações. Sorocaba/SP: Typographia Werneck, 1914, pp.52-53.

${ }^{36}$ Termo popular comumente utilizado para definir uma espécie de banheiro primitivo de dimensões exíguas (latrina).
} 
da Rua Ana Monteiro de Carvalho com a Avenida Dom Aguirre; ponto 5 - esquina da Avenida Dom Aguirre com a Rua Comendador Hélio Monzoni; ponto 6 - esquina da Rua Comendador Hélio Monzoni com a Alameda Kenworthy, voltando ao ponto inicial. Nesse período a vila tinha apenas uma entrada principal (como aos moldes dos atuais loteamentos fechados) localizada próximo à esquina da Rua Aparecida com a Alameda Kenworthy (ponto 1). Outro elemento que marcava profundamente a vila primitiva era o portal formado por duas palmeiras imperiais no final da Rua do Zico e início do perímetro da fábrica.

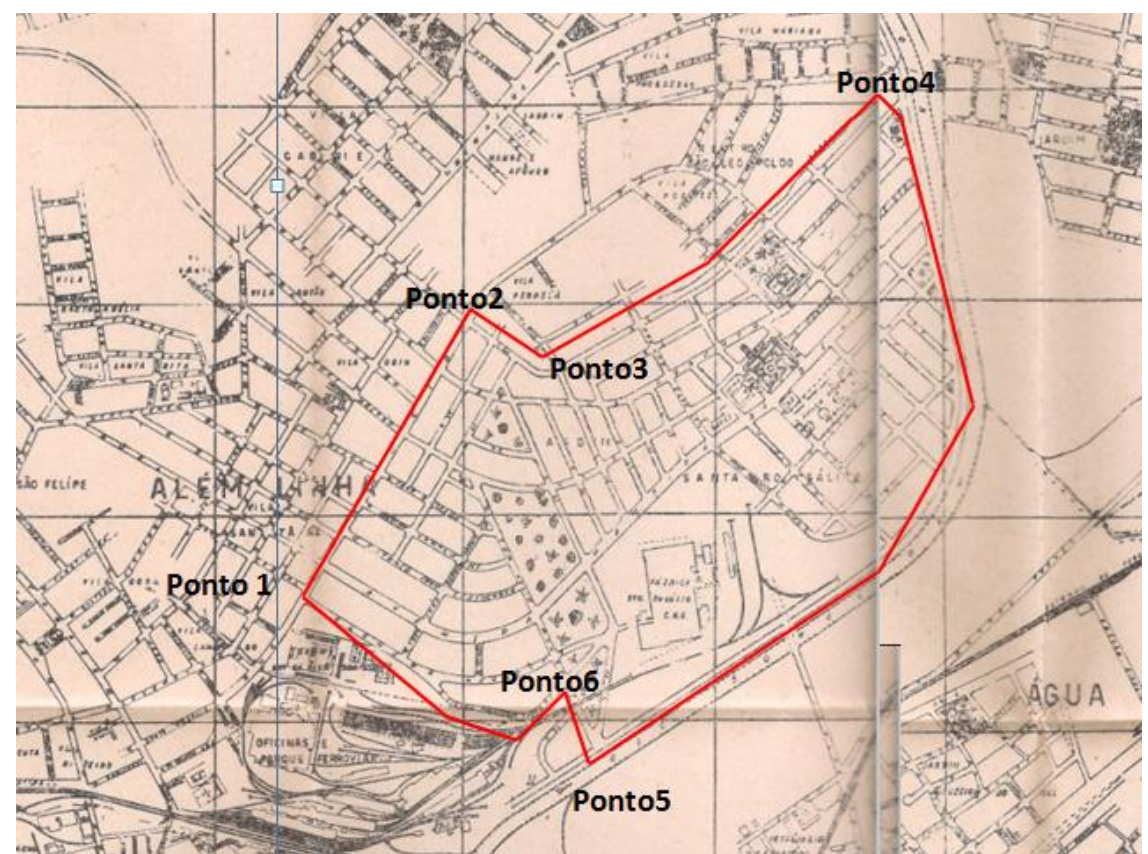

Figura 24: Mapa do antigo perímetro de propriedade da Fábrica Santa Rosália. Fonte: Planta da cidade de Sorocaba de 1962. Acervo de Gilberto Tenor.

Fora do perímetro da vila, próximas às instalações da fábrica, existiam três grandes casas conhecidas como "Mansões dos Ingleses" que eram as residências dos engenheiros e gerentes da fábrica. Não há registros de quando foram edificadas, nem fotografias, desenhos ou descrições precisas de como eram estes imóveis. Também próxima a essas residências havia uma espécie de curral (chamado de "Fazendinha") onde eram alojados os animais utilizados para o transporte de parte dos produtos, tanto matérias primas quanto produtos manufaturados (a maior parte dos produtos era transportada pelos trens da Sorocabana, através de um ramal próprio). Próximo a 
este local, nas margens do Rio Sorocaba, havia uma bomba hidráulica responsável pelo fornecimento de água encanada para todo o complexo.

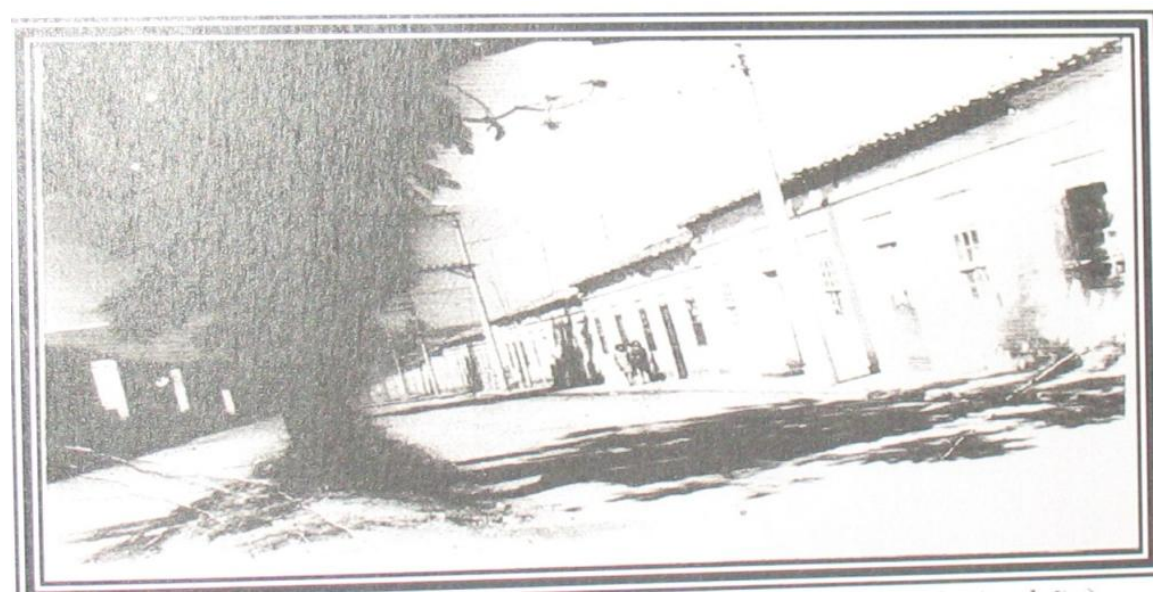

Figura 25: Vila primitiva de Santa Rosália - Rua São Francisco. Fonte: FIOROTTO Filho, Antonio. Aprazível Vila Santa Rosália 1890-2009. Do autor, 2009, p.11.

Para compreendermos como a CNE passou a ser a proprietária da Santa Rosália, primeiro precisamos entender como John Kenworthy, fundador da Companhia Nacional de Estamparia, veio ao Brasil e constituiu uma das primeiras holdings (empresas controladoras) têxteis do país ${ }^{37}$.

\section{Kenworthy e a Companhia Nacional de Estamparia - CNE}

Vindo de uma família de industriais ingleses, John nasceu em Oldhan em 12 de julho de 1839. Formou-se técnico industrial no Owens College (atualmente College of Science and Technology, UMIST - University of Manchester Institute of Science and Technology, pertencente a Victoria University of Manchester). "Casou-se aos 21 anos com Mary Jane Boothby Pownnall, de uma familia de intelectuais de Lancashire" ${ }^{38}$. Industrial em seu país, veio em 1878 ao Brasil, em busca de um clima que o ajudasse a curar-se de alguns problemas respiratórios. De acordo com relatos de sua neta, Dra.

\footnotetext{
${ }^{37}$ BONADIO; FRIOLI. Op. Cit. p. 158.

${ }^{38}$ BONADIO; FRIOLI. Op. Cit. p. 223.
} 
Zuleica Sucupira Kenworthy ${ }^{39}$, seu avô teria um amigo que falava um pouco de português e queria muito conhecer o Brasil. Com isso, John e seu amigo vieram para o Brasil, mais precisamente para o Rio de Janeiro. Dra. Zuleica nos disse que antes mesmo do navio chegar ao Rio, ainda margeando a costa brasileira próximo à Bahia, os males respiratórios que o atacavam já teriam acabado.

Como naquela época o Rio de Janeiro estava sob um grande surto de gripe espanhola, Kenworthy e seu amigo rumaram para as Minas Gerais, de trem, percorrendo inúmeras cidades durante alguns meses. Não estando muito confortável com toda a aventura, o amigo de John decide voltar para a Inglaterra. Kenworthy por sua vez, arrumou um guia (que não falava uma palavra em inglês) com o intuito de ir para Ouro Preto, local onde teria ouvido falar da presença de ingleses trabalhando nas minas de Morro Velho. Perdidos, ambos foram parar em Itabira do Mato Dentro. Através de um padre local, que sabia ler inglês (mas também não compreendia o idioma falado), soube de um problema enfrentado pela Companhia União que ele poderia auxiliá-los: o conjunto de máquinas têxteis que a empresa havia adquirido, provindas da Inglaterra e ainda encaixotadas, nunca foram instaladas e colocadas em funcionamento, pois, em duas ocasiões distintas, os técnicos ingleses que foram contratados para a função adoeceram e vieram a falecer assim que chegaram ao Rio de Janeiro, vítimas da febre amarela. Desde então, nenhum outro técnico aceitou o convite para o trabalho.

Domingos Guerra, proprietário da companhia, e o coronel Cristiano, seu cunhado, com a ajuda do padre que lia, mas não falava inglês, conseguiram negociar e convencer John a assumir o trabalho. Em pouco tempo, Kenworthy não só montou as máquinas, como também alterou todo o sistema de funcionamento previsto, modificou a planta do local, supervisionou a maneira como seriam feitas as novas construções, re-locou as máquinas, deu treinamento a todos os gerentes e operários, e, em aproximadamente um ano, pode deixar a fábrica em ótimo estado e em perfeito funcionamento.

\footnotetext{
${ }^{39}$ A quem eu gostaria de agradecer muitíssimo, por me receber tão carinhosamente em sua casa, na Granja Olga (atual condomínio Granja Olga, Sorocaba) e me relatar toda a história de sua família e das fábricas têxteis pertencentes à CNE (entrevista realizada no dia 15/05/2009.)
} 
Já falando um português, ruim, mas compreensível, retorna ao Rio de Janeiro para poder embarcar e voltar à Inglaterra. Contudo, acaba convencido por um nobre local a visitar a Província de São Paulo, que na época já começara a se destacar no cenário nacional pelas tentativas de industrialização.

Na capital paulista, surge um convite, através do Major Diogo de Barros, para dar assistência à fábrica de um coronel, Luiz Antonio Anhaia, em Itu (Fábrica de Tecidos São Luiz, a primeira fábrica a vapor que prosperou no Estado). Após resolver os problemas que a fábrica enfrentava, um novo convite surge: cuidar da fábrica de José Galvão de França Pacheco Júnior em Salto. Intensamente maravilhado com as quedas d'água e o clima local, passa a escrever constantemente para a esposa, que ainda estava na Inglaterra, convidando-a para mudar-se para o Brasil. Pouco tempo depois, Mary Jane e seus filhos se mudaram para Salto.

Depois de ter cumprido todos seus trabalhos na Fábrica Galvão e novamente com o intuito de voltar à Inglaterra, é procurado por outro industrial: desta vez, de Tatuí. Era Manuel Guedes, cuja fábrica, São Martinho, estava com problemas na sua produção. Em 1883 John muda-se com a família para lá e passa a morar numa casa construída especialmente para eles. Permanecem por quatro anos trabalhando na Fábrica São Martinho, deixando-a em ótimas condições de operação e lucratividade.

Em 1898 recebe novamente um convite para trabalhar em Salto, desta vez na Fábrica Júpiter, participando de todo remodelamento da mesma. Neste mesmo ano associa-se ao seu genro, Bento Pires de Campos, ao cunhado de Bento - Justiniano Seabra - e a Gabriel Dias da Silva. Juntos adquiriram maquinário para uma fábrica própria, que se chamou São Bento. Foi instalada em 1900, em Jundiaí, mais precisamente na Vila Arens. Tentou diversas vezes expandir seus investimentos têxteis, nesta cidade. Contudo não teve o apoio esperado das autoridades locais, que só lhe ofereceram terrenos para instalação de uma nova fábrica em locais inoportunos (alagadiços e insalubres). Sua mentalidade empresarial não concordava que as condições de trabalho dos operários fossem essas. Já pensando longe, acreditava que trabalhadores 
precisassem de condições de trabalho tais, que possibilitassem ao sujeito produzir e extrair prazer disso ${ }^{40}$. Dessa forma desiste de permanecer em Jundiaí e vê em Sorocaba a oportunidade de prosperar de maneira digna. Em 1903 compra a Fábrica de Fiação e Tecelagem Santa Maria. Desta vez em sociedade com o filho Alberto e os genros: Francisco de Sales Gomes, Bento Pires de Campos e Alcebíades Campos.

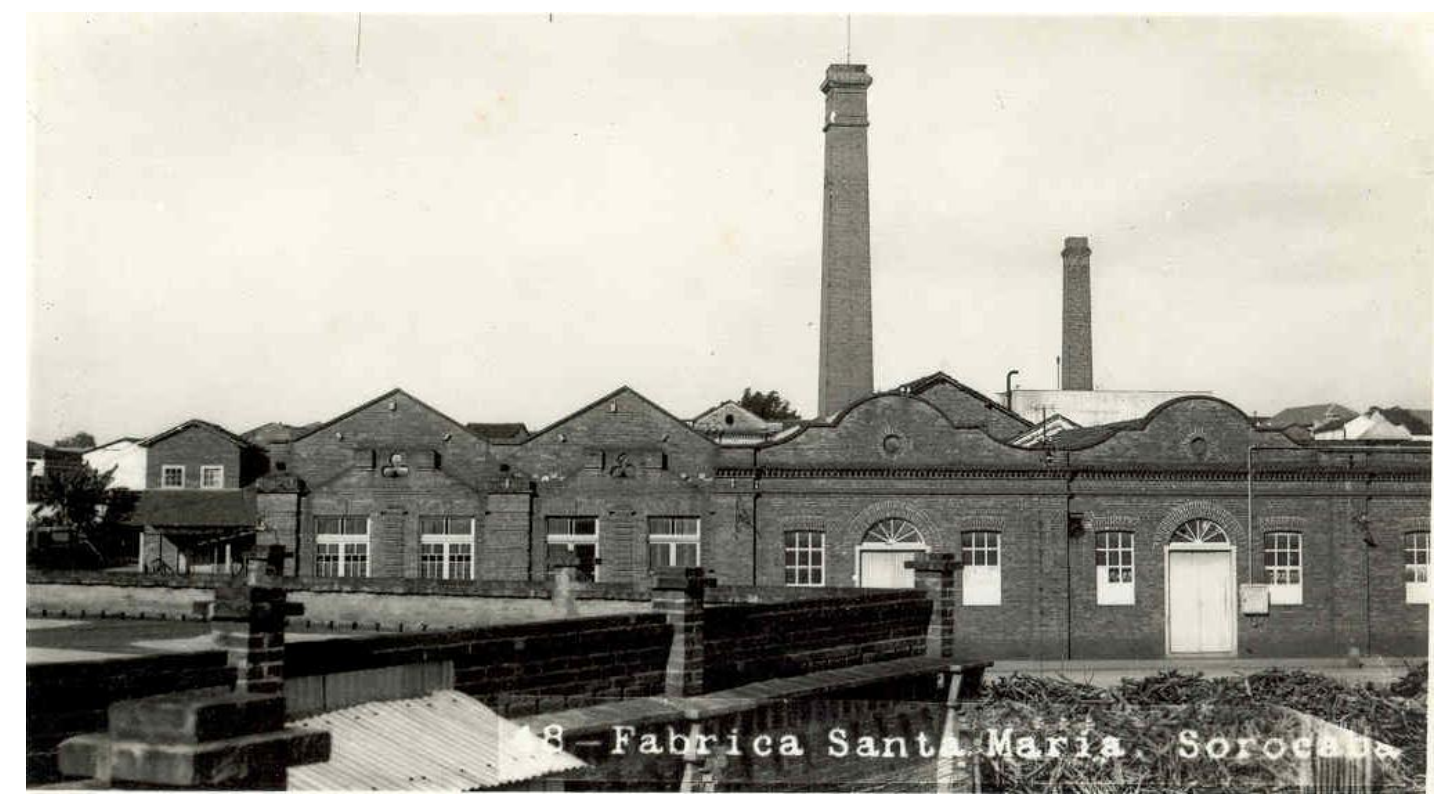

Figura 26: Fábrica Santa Maria. Fonte: Museu Histórico Sorocabano.

A Fábrica Santa Maria é outra grande indústria têxtil deste período analisado. Foi fundada em 1892 por Alexandre Marchisio, ex-gerente da fábrica de Manoel José da Fonseca, assim como: Joaquim Silvério Júnior, Francisco de Souza Pereira, Gabriel Dias de Oliveira e José Loureiro Júnior. Teve sua produção iniciada em 1896, mas a empresa pouco progrediu, sendo vendida logo em seguida para Hermann Burchard, que faleceu pouco tempo depois de adquirir a fábrica. E também foi visitada por Alfredo Moreira Pinto em sua passagem por Sorocaba segundo nos diz seu relato:

"Consta de um edificio rectangular construido de tijolos e alicerces de granito, com superestructura de madeiras duras do paiz e coberto de telhas nacionaes, tendo uma

\footnotetext{
${ }^{40}$ TOMAZELA, José Maria. Paulistânia: Zuleika, a pioneira da promotoria. IN: JORNAL O ESTADO DE SÃO PAULO. 10.05.2009, p. C-10.
} 
superficie de 3.150 metros quadrados, dividido em cinco compartimentos, formando uma sala de tecelagem, uma para a machina a vapor e outra para as caldeiras ou

geradores.

A superficie dos terrenos pertencentes ao estabelecimento é de 3.150 metros quadrados, ocupados pelo edificio, e mais 68.850 metros quadrados, que o circumdam.

Um ramal ferreo particular liga a frente dôo edificio com a via-ferrea Votorantim e com a estação de Sorocabana.

O motor geral da fabrica consta de uma machina a vapor de expansão e condensação, com um cylindro de 23 pollegadas de diametro e 48 de percurso, volante de 18 pés, com jabres para receber nove cabos de pollegada e tres quartos de diamentro, construído para desenvolver uma força de 250 cavallos effectivos, com pressão de 100 libras.

Uma caldeira de aço, de 28 pés de comprimento por sete de diâmetro, typo Cornwall, alimenta a machina com vapor, havendo logar para montar uma segunda caldeira egual, ou mesmo uma terceira.

Uma chaminé de 30 metros de altura, construida de tijolos, com o competente pararaios, faz a tiragem necessaria.

Possue mais o estabelecimento um motor electrico de 12 cavallos, que manobra á distancia de 150 metros as bombas que supprem com agua do rio Sorocaba.

Um tanque de ferro, da capacidade de 50.000 litros, domina, pela sua elevação a summidade do edificio, ditribuindo agua para o differentes mistéres.

Para fabricação de tecidos do typo Busto o edificio tem dimensões para conter 150 teares com fiação e cardas correspondentes.

O estabelecimento contém actualemente 110 teares mecanicos e todas as machinas necessarias para o preparo do fio em espulas, carreteis e urdição. Possue uma esplendida machina de engommar o fio, machinas de dobrar e medir a fazenda, machinas de preparar as peças, prensa para a apparelhamento e prensa hydraulica para enfardamento; torno mecanico e officina completa para concertos em edificio separado.

As transmissões são todas de aço polido, em mancaes de bronze e lubrificadores automaticos.

O combustivel empregado é a lenha. São proprietarios dessa fabrica Marchisio, Loureiro Silverio \& C."41

Com a nova administração e direção iniciada em 1903, a Santa Maria sai da estagnação, se moderniza (através da mudança de seu layout, aquisição de novas máquinas e eletrificação de suas dependências) e entra em um período de grandes

\footnotetext{
${ }^{41}$ Pinto, Alfredo M. Op. Cit, pp. 21-22.
} 
lucros, chegando, em 1914, a ter 650 operários ${ }^{42}$. Produzia 3.000 .000 de metros de tecido ao ano (brins, chitas, flanelas e lenços).

Seu edifício possuía um engenhoso sistema de iluminação e ventilação diferentes das demais fábricas: sua cobertura era formada por uma série de telhados de quatro águas, onde as duas águas menores eram mais baixas, possibilitando a entrada de iluminação natural pelas janelas altas. Sua chaminé, também se destacava por ser a única das fábricas sorocabanas a ter uma chaminé de seção quadrada, que se localizava no meio do edifício principal. O conjunto da fábrica era completado pelo edifício da administração (casa grande), que se localizava na parte frontal do imóvel, destoando dos demais edifícios que seguiam a linguagem fabril. A Santa Maria também possuía uma pequena vila operária, localizada a poucos metros da fábrica, que se resumia a uma pequena rua com casas geminadas e uma praça.

Se em Jundiaí John Kenworthy não teve muito êxito nas negociações com o poder público local, em Sorocaba as condições foram mais favoráveis. Com a recém instalada companhia local de força e luz (que fornecia energia para a Fábrica Santa Maria), juntamente com a doação de um excelente terreno pela prefeitura, pôde, cinco anos depois, construir uma nova fábrica, a Alvejaria, Tinturaria e Estamparia São Paulo, constituindo assim a Companhia Nacional de Estamparia (CNE), inaugurada em 1909. Inicialmente suas máquinas funcionaram movidas a vapor, sendo que posteriormente foi construída, ao lado do rio Sorocaba, uma usina elétrica movida a diesel.

Originalmente os edifícios que compunham a estamparia seguiam os mesmos princípios estéticos das demais fábricas do período. Contudo, Por tratar-se de um tipo de produção que teve sua tecnologia de maquinário e processo de fabricação modificado e modernizado muitas vezes para atender a novas exigências de mercado e exigências ambientais, tornaram-se necessárias transformações que fizessem frente às novas demandas. Com isso, é possível observarmos nas raras imagens coletadas, que os edifícios da fábrica foram se ampliando paulatinamente, constituindo assim um tipo

\footnotetext{
${ }^{42}$ BONADIO. Op. Cit. p.226.
} 
de implantação "desorganizada", ou seja, eram inúmeros pequenos edifícios que conformavam o conjunto, além do edifício principal que foi ampliado diversas vezes.

Em discurso de sua posse como sócia do Instituto Histórico, Geográfico e Genealógico de Sorocaba disse, Dra. Zuleica disse:

"lembrar-se que o tio Frank (Franklin Kenworthy) cuidava da contabilidade, o tio Alberto (Albert Kenworthy) era encarregado da compra de algodão e seu pai, Jorge (George Kenworthy), era o gerente da produção. Na época, a tecelagem era um exemplo para o mundo todo e tudo que havia de mais moderno havia sido previsto $e$ utilizado na construção da fábrica como, por exemplo, luminosidade e ventilação naturais, nível de ruído máquinas a vapor e não ficava longe do local onde os operários moravam. Lembra-se também que, até então, só existiam os tecidos de algodão cru ou de algodão alvejado, e um irmão de seu avô, que era engenheiro químico, trouxe da Inglaterra a técnica da estamparia. Com os primeiros tecidos estampados foram feitas algumas sombrinhas com desenhos coloridos de flores e ela achava aquelas sombrinhas lindas". ${ }^{43}$

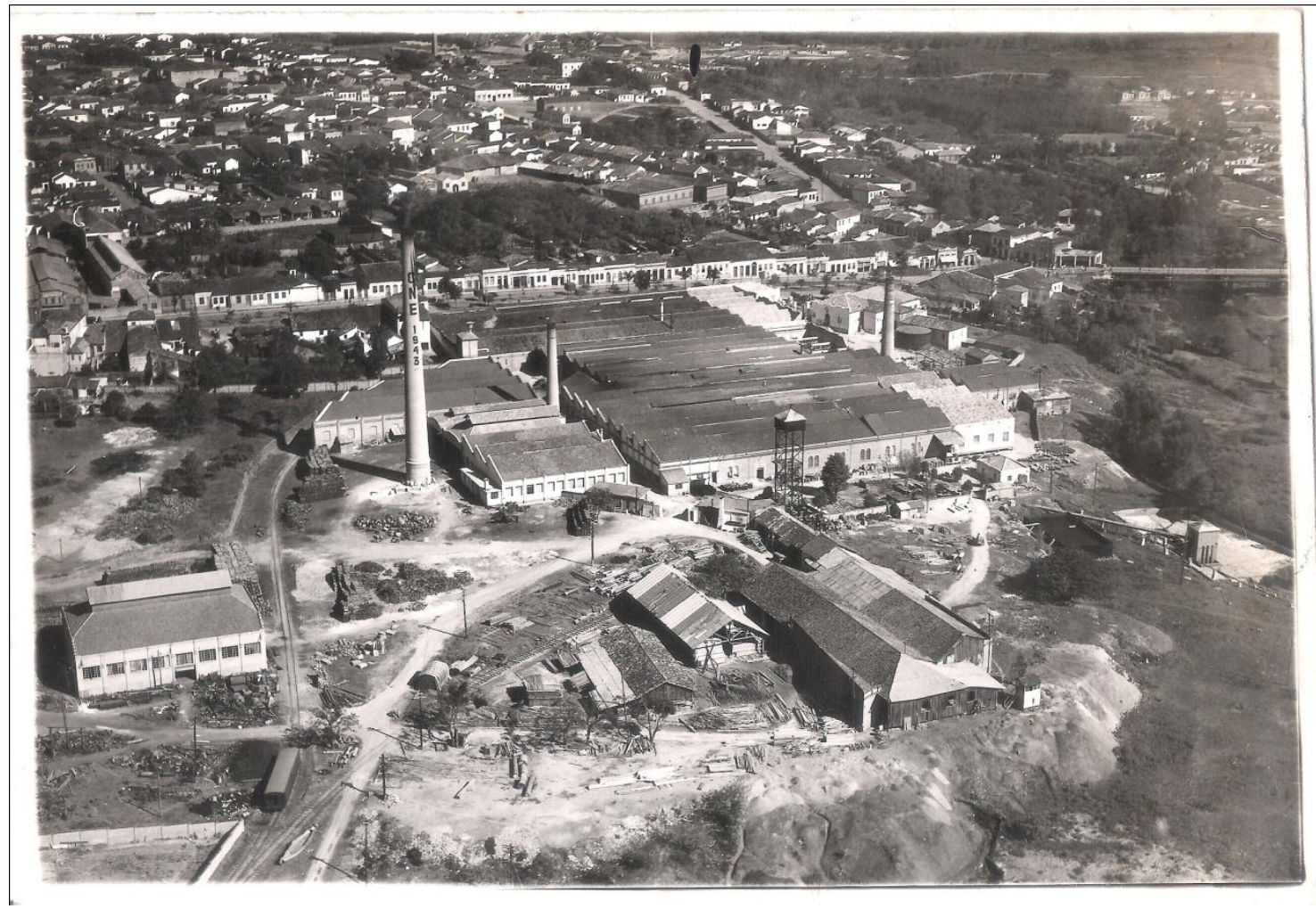

Figura 27: Fábrica São Paulo, 1943. Fonte: Acervo Gilberto Tenor

\footnotetext{
${ }^{43}$ INSTITUTO HISTÓRICO GEOGRÁFICO E GENEALÓGICO DE SOROCABA. Discursos de Posse. Disponível em: $<$ http://www.ihggs.org.br/index.php?option=content\&task=view\&id=178\&/temid=119 $>$. Acessado em 25/09/2008.
} 
Em 1910 inicia o projeto da quinta e última grande fábrica têxtil desse período áureo: a Fábrica Santo Antônio, concluída em 1913. De todas as indústrias edificadas e implantadas pelos Kenworthy, a Santo Antônio foi o exemplar onde puderam levar às últimas conseqüências os conceitos inovadores de higiene, saneamento, ventilação e iluminação naturais que tanto defendiam em suas instalações. Esse fato, somado com a diferenciada vila operária (que começava na Rua Comendador Oetterer e fazia limites com a fábrica e o Córrego Supiriri) faziam dela um exemplar notável de arquitetura da época. A vila era formada por diversos sobrados distribuídos em ruas internas - que "tinham nome de virtudes da era industrial: Igualdade, Fraternidade, Prosperidade, Eqüidade, Perseverança..." 44 -, sendo que algumas delas possuíam frente para a Rua Antônio Alvarenga. Além disso, o bairro operário contava com uma creche, um campo de futebol, hortas domésticas (que eram cuidadas pelos próprios funcionários), juntamente com um armazém do Serviço Social da Indústria (que viria a ser instalado em 1947). Foi nesta vila também onde funcionou pela primeira vez na cidade (por um curto período, sendo transferida posteriormente para uma sede mais apropriada) uma Escola SENAI.

\footnotetext{
${ }^{44}$ FRIOLI; BONADIO. Op Cit. p. 165. Infelizmente o único registro e/ou relato encontrado a respeito desta vila.
} 


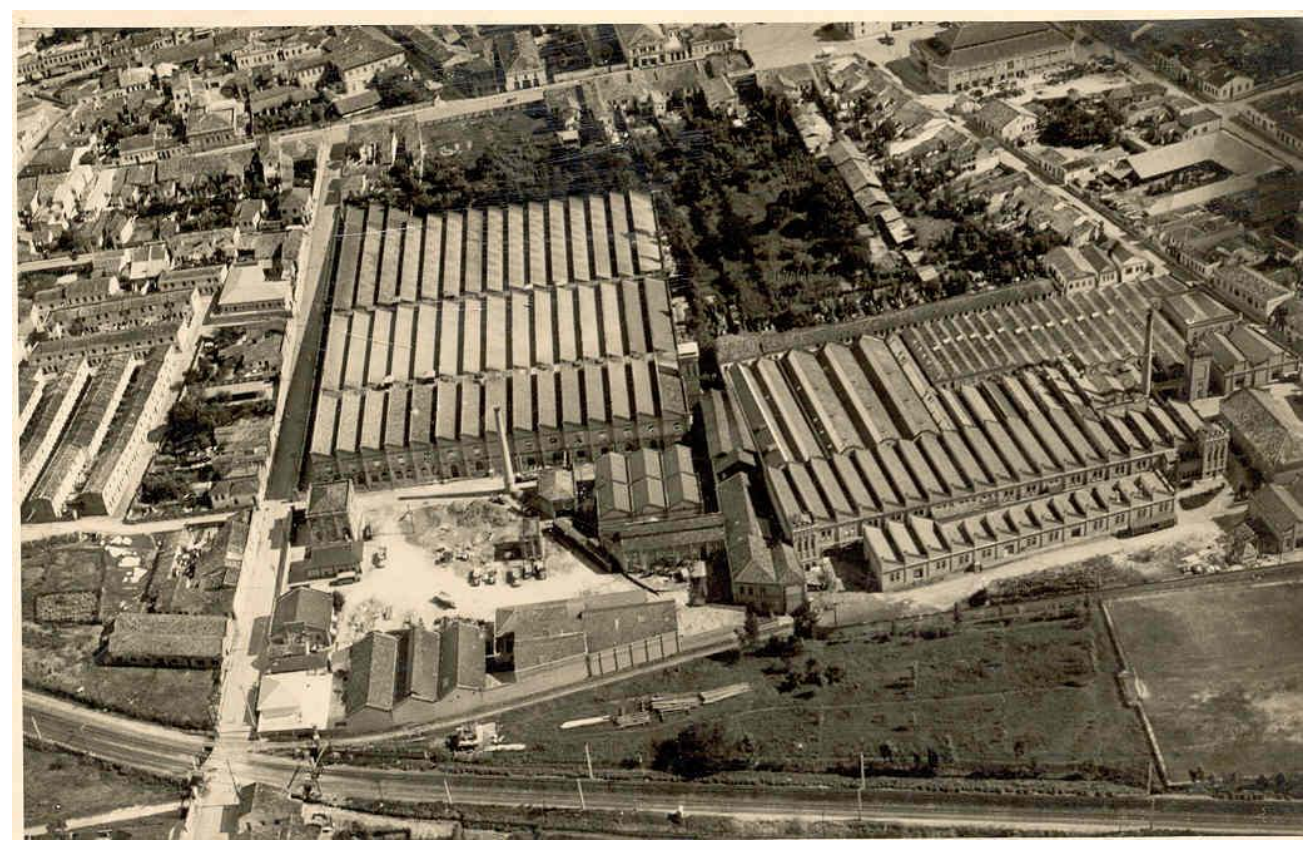

Figura 28: Fábrica Santo Antônio (esq.) e Fábrica Nossa Senhora da Ponte (dir.), década de 1940 (?). No canto esquerdo da imagem é possível observar a vila operária da Fábrica Santo Antonio. Fonte: Museu Histórico Sorocabano.

A Fábrica Santo Antonio possuía um sistema construtivo semelhante ao das outras indústrias em questão: fundações de pedras (granito) que sustentavam as paredes de alvenaria de tijolos comuns auto-portantes assentados em aparelho inglês; pilares e perfis de ferro fundido sustentavam a cobertura do telhado composto de telhas de barro e madeiramento. Em sua fachada principal era possível visualizar os sheds da cobertura, orientados para a face sul, possibilitando a entrada de iluminação natural difusa e permitindo a ventilação através das aberturas basculantes. Sua fenestração era composta de aberturas em arcos plenos (janelas do térreo e andar superior) e rosáceas (janelas altas), fechadas por esquadrias de ferro e vidro basculantes, sendo que algumas dessas janelas tinham sistema de abertura para dentro ${ }^{45}$.

\footnotetext{
${ }^{45}$ Processo n $9761 / 93$, p.113.
} 
O prédio era retangular e composto por dois pavimentos, sendo a base/ térreo (onde era o depósito), caracterizado pela alvenaria de pedras em aparelhamento regular tosco de alvenaria aparelhada e pouca iluminação (apenas das janelas laterais); o andar superior (produção), vedado em alvenaria de tijolos, era composto de dois grandes salões contendo a malha de pilares metálicos, separados por um grande corredor central que organiza o fluxo de pessoas e a distribuição de materiais através de um elevador de cargas. As paredes internas do edifício eram revestidas com argamassa de areia e cal, pintadas com tinta à base de cal. Na frente da propriedade estavam distribuídos pelo pátio diversos pequenos edifícios de apoio à produção: Subestação de energia principal; Casa de Compressores (antiga portaria); Oficinas; refeitório; Casa de caldeiras e depósito de cavacos; Remessa e depósito de fardos; Depósito e treinamento; e Casa de bombas. Também neste pátio se localizava o elemento mais marcante da fábrica: sua enorme chaminé de seção circular.

A entrada de funcionários se dava pela fachada lateral (Rua Comendador Oetterer), marcada por uma discreta saliência formada por duas pilastras e um frontão triangular, por onde tinham acesso ao corredor central citado anteriormente. Imediatamente após a porta de entrada, existe uma pequena escada que leva a um portal composto por pedras e fechado por um portão de ferro. Neste corredor, a cobertura era distinta do restante do edifício, sendo formada por um lanternim. Também é importante citarmos a existência de uma escada metálica externa que dava acesso direto a área de produção, assim como todo o fechamento da propriedade que era feito por um belíssimo muro de alvenaria seguindo os padrões da edificação.

Além de todos esses investimentos na compra e construção de novas fábricas, a família Kenworthy passou a investir em ações de outras fábricas, mais precisamente da Santa Rosália, que tinha acabado de se tornar uma empresa de capital aberto. É neste período que a CNE passa a comandar a Santa Rosália, pois acaba comprando a maior parte das ações da empresa. Bonadio relata que esta negociação não foi nem um pouco pacífica, pois assim que a CNE passou a acionista majoritária, mudou os 
gerentes que comandavam a fábrica, designando para esta função Braulio Guedes e Helio Monzoni. Estes por sua vez se demonstraram ótimos nesta função:

"[...] suspenderam o pagamento de dividendos (Sic) e obrigaram os proprietários originais a, pouco a pouco, irem vendendo o restante das ações. As fábricas da CNE, por essa época, já eram abastecidas com energia elétrica geradas em usina próprias, instaladas em Pilar do Sul" ${ }^{46}$.

Mesmo com uma gestão adequada e bons dividendos, os Kenworthy tiveram de enfrentar dificuldades que não estavam previstas. John foi pai de quatro filhos, cujos estudos e educação foram dirigidos para sucedê-lo nas empresas. Mas infelizmente todos vieram a falecer muito jovens (antes dos quarenta anos). A situação foi agravada pela não concessão de créditos bancários, devido à tensão gerada pelo início da segunda guerra mundial, cuja alternativa foi o empréstimo de bancos nacionais, com altos juros. ${ }^{47}$. Essa somatória de fatores (juros altos e falta de profissionais com o mesmo perfil dos jovens filhos dos Kenworthy) levou à perda gradativa das ações da CNE para os bancos. Sem outras opções, negociaram juntamente com os bancos a venda da CNE para Severino Pereira da Silva.

A gestão Kenworthy trouxe, a partir de 1914, muitos benefícios para as fábricas e principalmente seus bairros operários, como: iluminação pública, Igreja de Santa Rosália, sede da Congregação Mariana, escola maternal, creche, grupo escolar, a construção de uma praça chamada São Carlos, onde anteriormente era o campo de futebol, transferindo-o para um novo local, com medidas maiores.

\section{A Igreja de Santa Rosália e a Congregação Mariana}

A Igreja de Santa Rosália e a Congregação Mariana foram as primeiras edificações não residenciais a serem realizadas na Vila de Santa Rosália, após a inauguração da fábrica em 1895. Não há registros da data de início e término da construção das mesmas. Sabe-se que foram edificadas durante o período em que o diretor da fábrica era o senhor Hélio Monzoni ${ }^{48}$. Os edifícios se localizavam em frente ao terreno onde os

\footnotetext{
${ }^{46}$ BONADIO. Op. Cit. p.224.

${ }^{47}$ Cf. entrevista concedida pela Dra. Zuleica Sucupira Kenworthy, citado anteriormente.

${ }^{48}$ ALMEIDA, Aluísio de. Sorocaba: 3 Séculos de História. Itu (SP): Editora Ottoni, 2002, p. 384.
} 
funcionários costumavam jogar futebol. Alguns anos depois, nesse local seria construída a Praça São Carlos (atual Praça Pio XII).

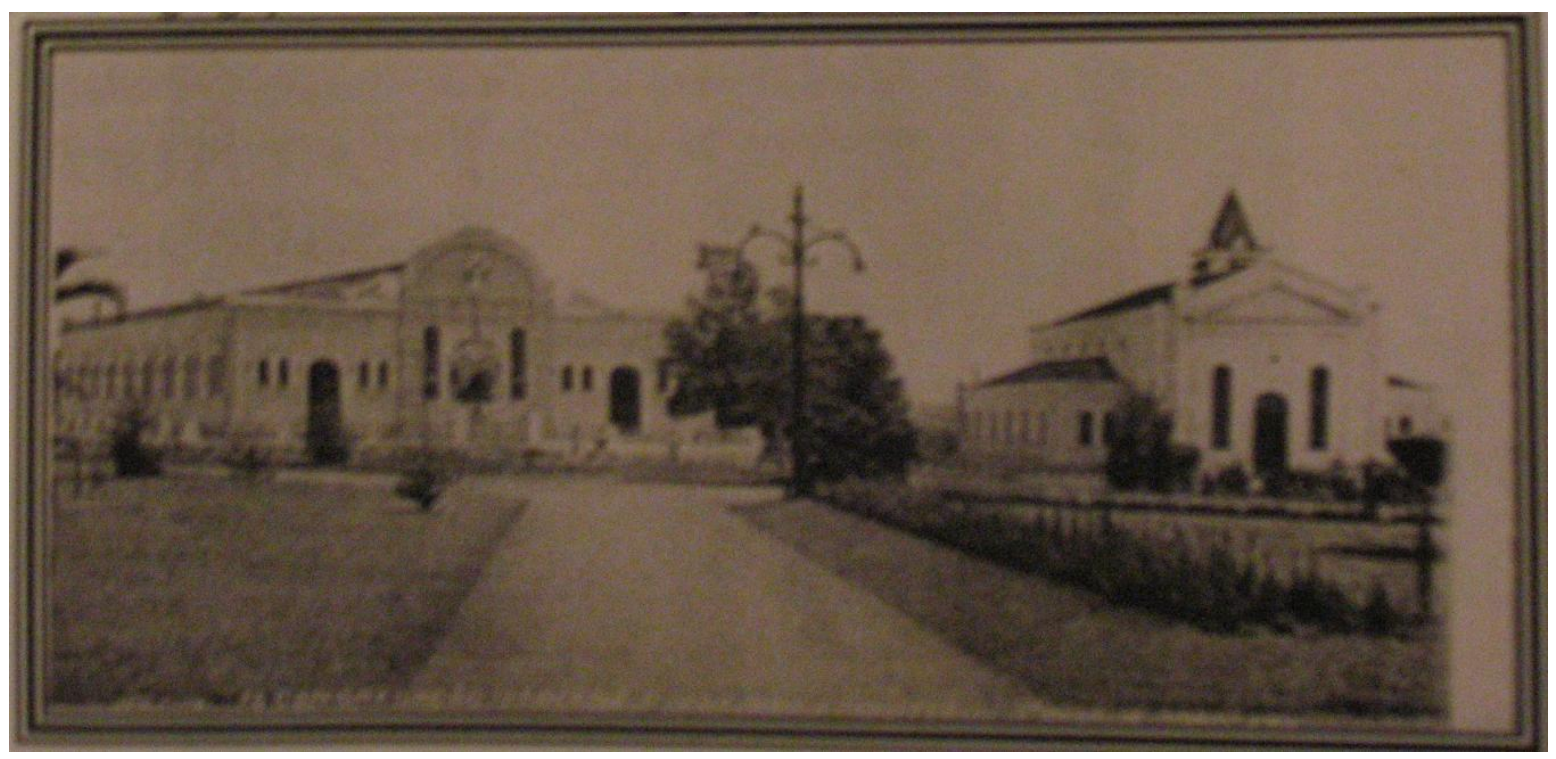

Figura 29: Congregação Mariana (esq.) e Igreja de Santa Rosália (dir.), década de 1940 (?). Fonte: FIOROTTO Filho, Antonio. Aprazível Vila Santa Rosália 1890-2009. Do autor, 2009, p.13.

Eram edifícios complementares: enquanto que na Congregação Mariana se realizava reuniões, eventos sociais, peças de teatro, ensaio e apresentação de corais, festas e projeções de filmes para os operários, na Igreja de Santa Rosália eram celebradas as missas e demais celebrações católicas. A administração de cada um dos edifícios foi dividida entre os Congregados Marianos (juntamente com o Apostolado da Oração, com as Filhas de Maria e com os Marianinhos) e os Beneditinos (Ordem de São Bento, sediada na Igreja de Sant'Anna/Mosteiro de São Bento).

Há raros registros destes edifícios (apenas algumas poucas fotos). Esses prédios eram bastante freqüentados pela população operária, pois significavam centros de convívio social do bairro. Os operários tinham poucas opções de lazer e a igreja, seguida do futebol, eram oportunidades importantes para essas pessoas.

Ambos os edifícios foram demolidos para dar lugar à nova paróquia de Santa Rosália, na década de 1960. 


\section{O Grupo Escolar}

O Grupo Escolar de Santa Rosália, que se localizava na Rua "A" em frente à Praça São Carlos (atuais Avenida Pereira da Silva e Praça Pio XII), foi o quinto grupo escolar da cidade de Sorocaba. Teve sua construção iniciada em 1922 e foi inaugurado em 18 de janeiro de $1925^{49}$. Fora planejado com o intuito de oferecer educação básica aos filhos dos funcionários, associado aos outros dois estabelecimentos: creche e escola maternal. Na época, ao concluir o ensino primário no grupo escolar, o aluno já estava apto a se tornar aprendiz, ingressando nos trabalhos da fábrica. $O$ prédio também abrigava nos finais de semana, os ensaios da Banda de Música dos Operários da Fábrica Santa Rosália, depois chamada de Corporação Musical "Carlos Alberto Pereira".

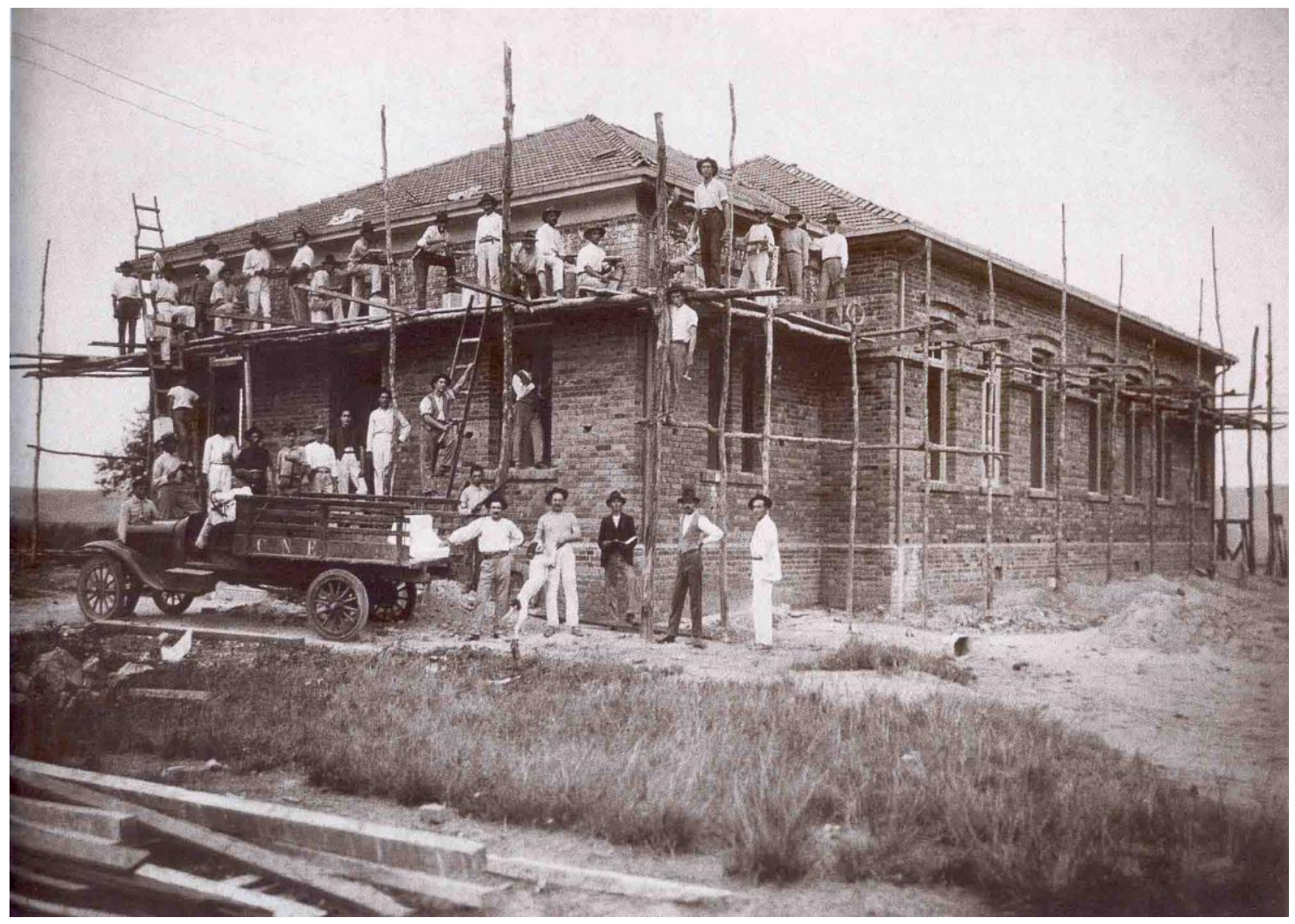

${ }^{49}$ DIÁRIO OFICIAL DO ESTADO DE SÃO PAULO. 18.01.1925, p. 506. 
Figura 30: Construção do Grupo Escolar da Vila de Santa Rosália, 1922. Foto de Pedro Neves dos Santos. Acervo: Museu Histórico Sorocabano Fonte: FRIOLI, Adolfo. Sorocaba: Registros Históricos e Iconográficos. São Paulo. Editora Laserprint, 2003.

É um dos raros exemplares da Vila de Santa Rosália que conta com documentação de sua construção, alem de ser o único edifício fora do perímetro da fábrica que segue os moldes da arquitetura inglesa: alvenaria de tijolos aparentes com um alto grau de sofisticação no assentamento, sendo a base do edifício revestida com argamassa de areia e cal (porão alto), o corpo em alvenaria de tijolos aparentes (aparelho inglês), frisos em tijolos marcando a divisão da fenestração (janela/bandeira), moldura em estuque que ocultava todas as calhas do prédio e cobertura em telhas francesas. Todo o perímetro do terreno da escola era cercado por um muro baixo com um gradil de ferro ornamentado.

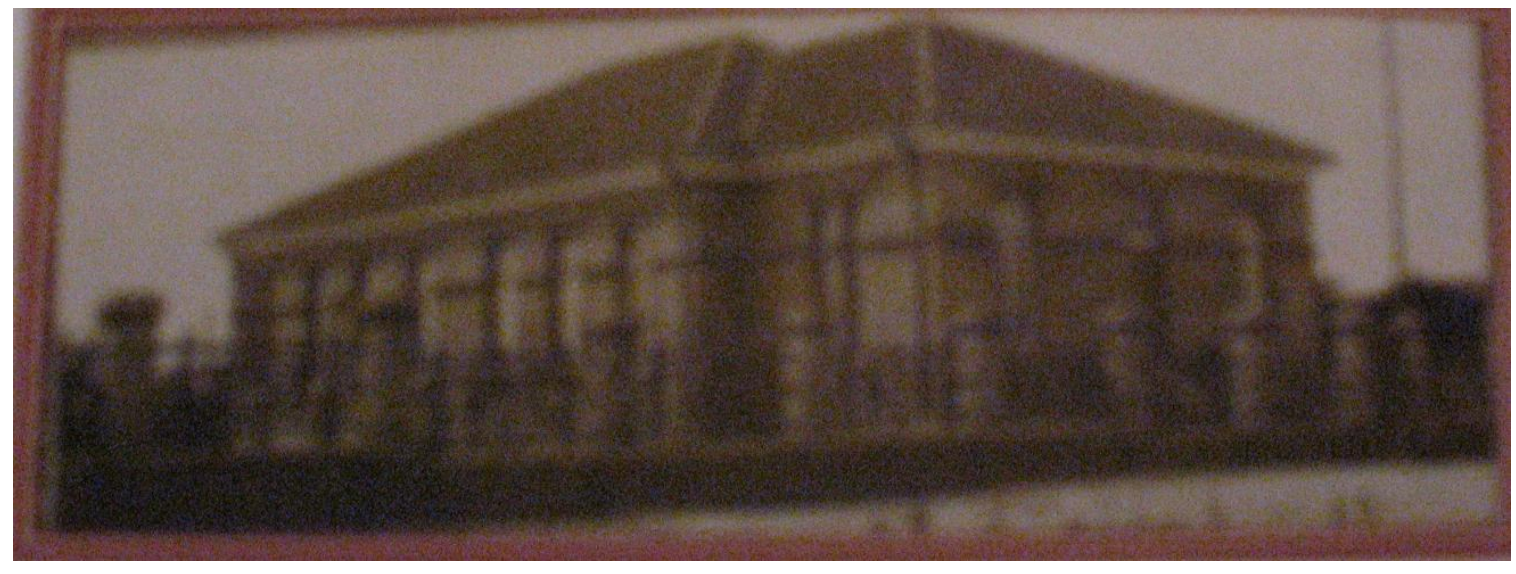

Figura 31: Grupo Escolar de Santa Rosália logo após a sua conclusão, 1924. Foto de Pedro Neves dos Santos. Fonte: Fiorotto Filho, Antonio. Aprazível Vila Santa Rosália 1890-2009. Do autor, 2009, p.58.

O Grupo Escolar Santa Rosália funcionou neste estabelecimento até 15 de abril de $1981^{50}$, quando o Governo do Estado de São Paulo transfere a escola para um edifício próprio (a CNE alugava o prédio para o Estado) também localizado no bairro de Santa Rosália, mudando o nome da escola para "Professor Ezequiel Machado Nascimento".

Após o fechamento, o edifício não teve nenhuma outra utilização e ficou abandonado durante alguns anos, sendo demolido ainda nos anos 1980. Seu terreno ficou

\footnotetext{
${ }^{50}$ DIÁRIO OFICIAL DO ESTADO DE SÃO PAULO. 15.04.1981, Seção I, p. 3.
} 
desocupado por mais de 20 anos, abrigando por um curto período um estacionamento, e hoje um restaurante (que fora inaugurado em 2008).

\section{Grêmio Recreativo}

Vizinho do Grupo Escolar, em frente à Praça São Carlos,

"existiu a Sede do Grêmio Recreativo, onde eram realizados os bailes dançantes aos sábados, domingos e feriados, como entretenimento aos moradores da Vila. Ali também eram realizados os Shows da Rádio Cacique de Sorocaba, com a parceria de cantores e humoristas..." ${ }^{51}$.

Não há registros fotográficos deste edifício, nem as datas exatas de sua construção, inauguração e demolição. Os únicos relatos escritos são do Almanaque de 1914 e do Livro a Aprazível Vila de Santa Rosália, além de relatos orais de antigos moradores.

\section{A Escola Maternal}

Inaugurada em 20 de março de 1924, a Escola Maternal de Santa Rosália fora criada para atender aos filhos dos operários com idade entre três e sete anos. Proporcionava aos alunos uma preparação pré-escolar, além de alimentação, material e atividades em geral.

\footnotetext{
${ }^{51}$ FIOROTTO FILHO, Antonio. Aprazível Vila Santa Rosália 1890-2009. Do autor, 2009, p.79.
} 


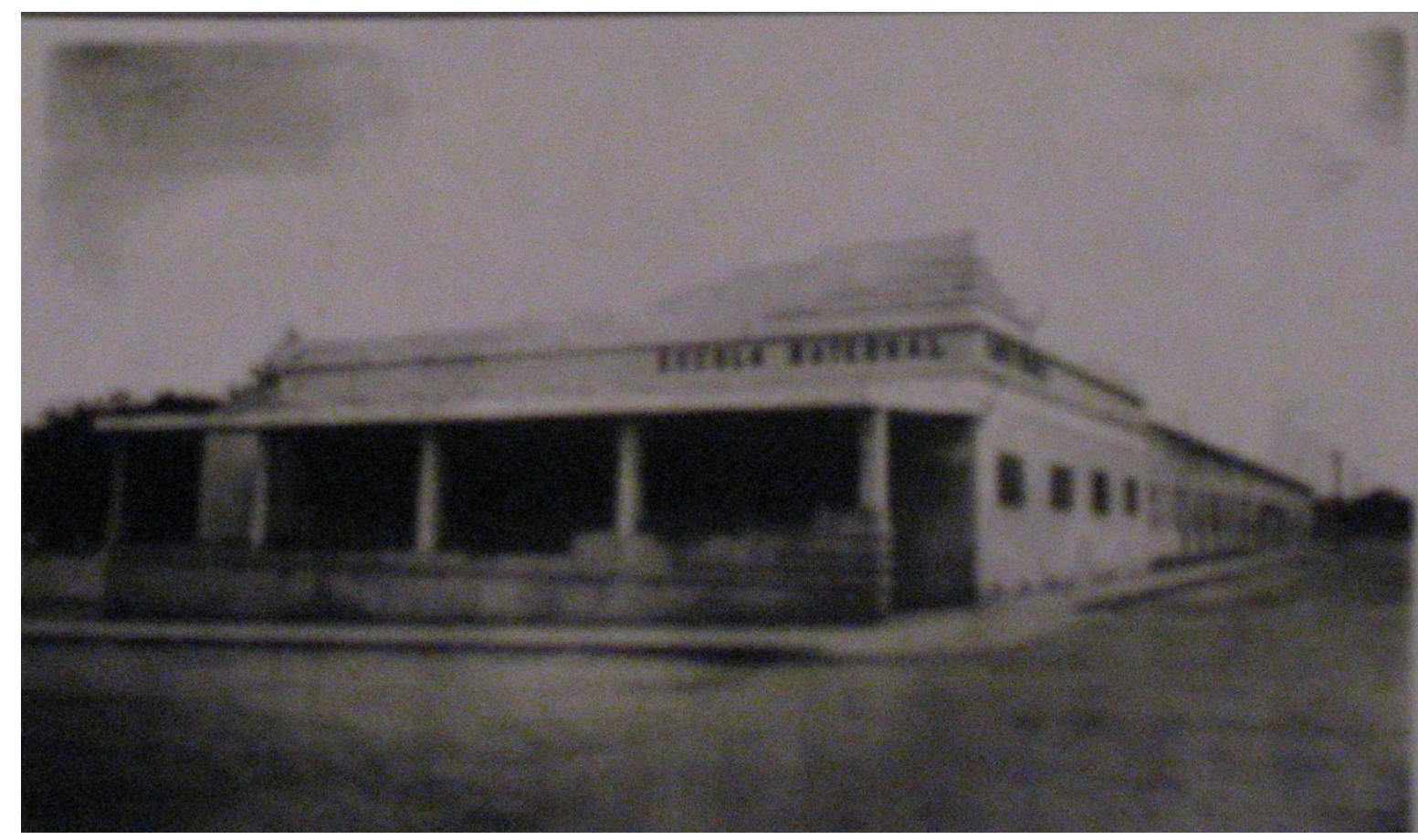

Figura 32: Escola Maternal, lateral da Praça São Carlos, década de 1940 (?). Fonte: Fiorotto Filho, Antonio. Aprazível Vila Santa Rosália 1890-2009. Do autor, 2009, p.61.

Localizava-se na Rua "A" (atual Avenida Pereira da Silva), na lateral da Praça Pio XII. Era um edifício simples, sem recuos, exceto pela entrada principal, onde havia uma marquise. Construído em alvenaria de tijolos, revestidos em argamassa de cal e areia, cobertura em telhas francesas, ocultas por uma platibanda escalonada onde havia a inscrição Escola Maternal.

Este estabelecimento funcionou até 1942, quando foi transformado em escola Ginasial.

Além destas benfeitorias e recursos criados pela gestão Kenworthy, seria interessante mencionar que não podemos separar o fato de terem adquirido propriedades em Sorocaba, que viriam a passar por transformações importantes. São as seguintes: 


\section{A Residência Kenworthy (Palácio Episcopal)}

A Residência onde a família Kenworthy residiu localizava-se na Rua XV de Novembro, no quarteirão entre a Rua Brigadeiro Tobias e a Praça Dr. Arthur Fajardo ${ }^{52}$. Lá permaneceram até a morte prematura dos filhos de John Kenworthy, que o obrigou a tomar conta da empresa, juntamente com as noras e netos. Neste período a família acaba dispersando e a propriedade é vendida à Diocese de Sorocaba.

Na década de 1930, a antiga residência do Kenworthy se transforma no Palácio Episcopal de Sorocaba (mais conhecido como "Casa do Bispo"), sendo ao seu lado construída uma capela e um grande jardim. Este foi a segunda residência episcopal da cidade.

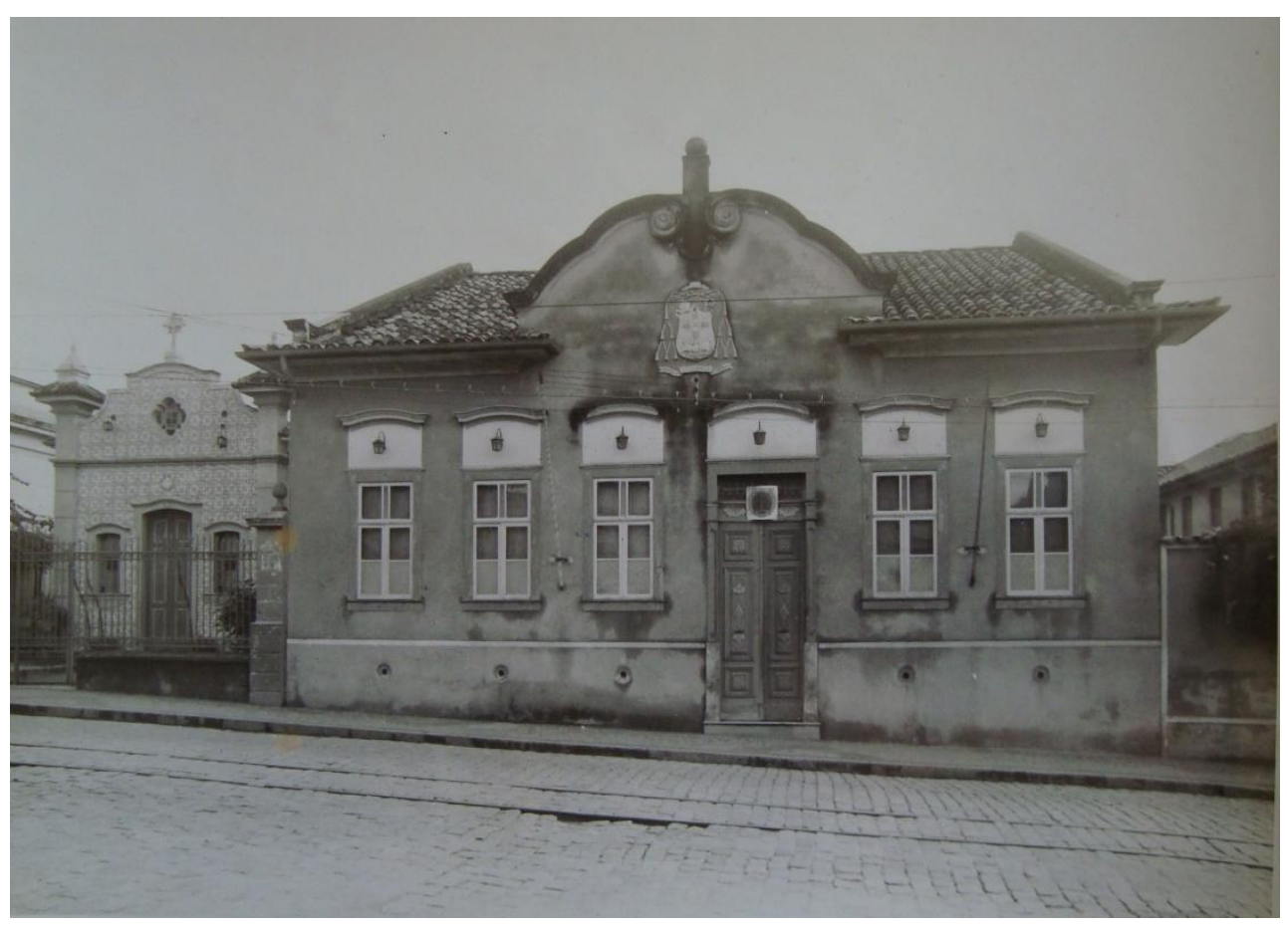

Figura 33: Palácio Episcopal - 1950. Fotógrafo desconhecido. Fonte: Acervo IHGGS

Na década de 1970, o residência episcopal foi transferida para junto do Seminário São Carlos Borromeu, localizado na Avenida Eugênio Salerno. O antigo casarão foi vendido

\footnotetext{
${ }^{52}$ Cf. depoimentos da Dra. Zuleika Sucupira Kenworthy, em entrevista cedida no dia 15 de maio de 2009, em sua residência, no Residencial Granja Olga.
} 
para o banco do Brasil, que o demoliu juntamente com a capela lateral. Atualmente continua sendo a sede central da instituição bancária na cidade de Sorocaba.

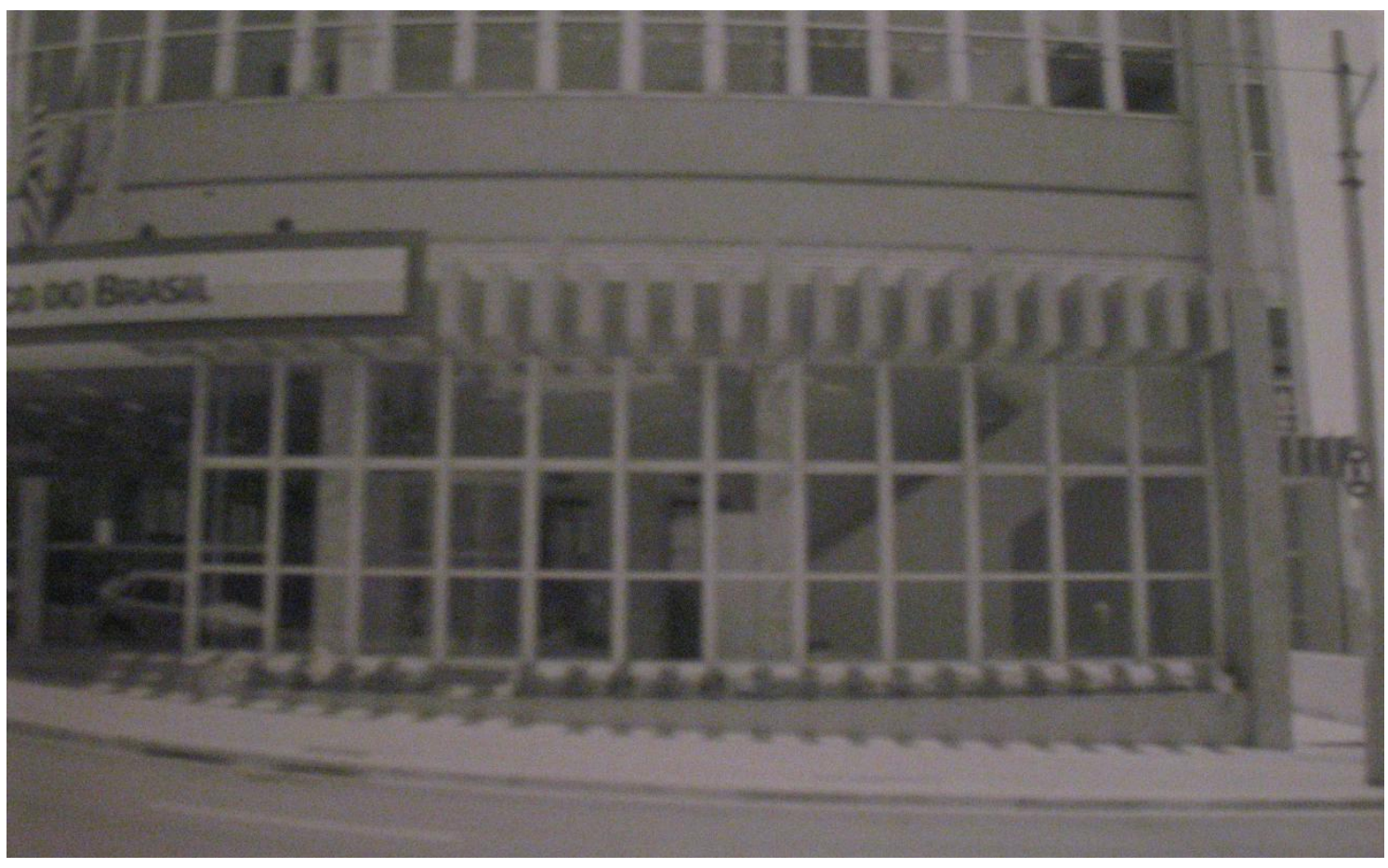

Figura 34: Sede do Banco do Brasil, Rua XV de Novembro, 2003. Fonte: Rangel, Paulo R. Máquinas do Tempo. Sorocaba, SP: Crearte, 2004, p.31.

\section{Granja Olga}




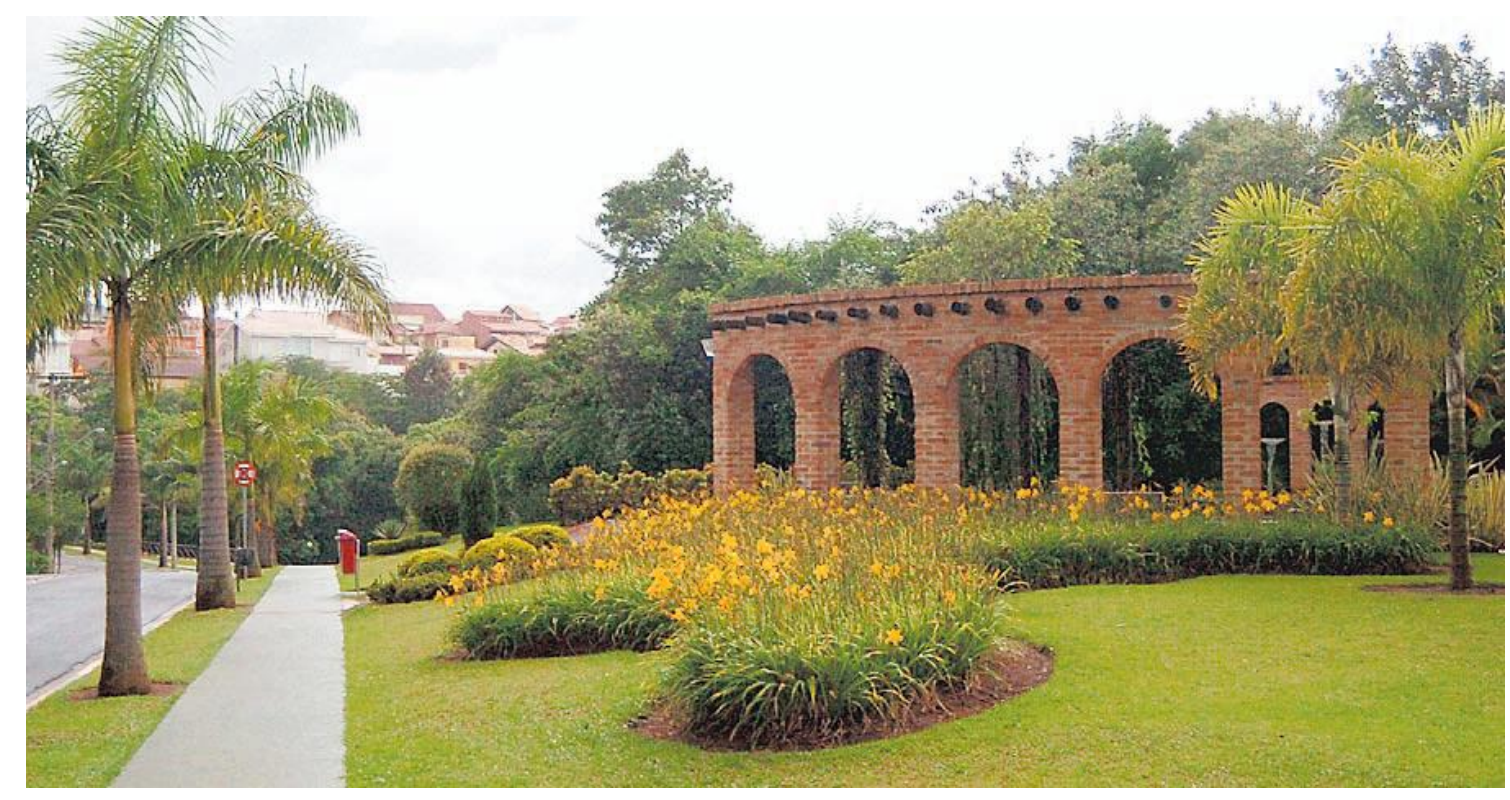

Figura 35: Condomínio Granja Olga. Fonte: EMIDIO MARQUES. JORNAL CRUZEIRO DO SUL, 8.3. 2009.

A propriedade Granja Olga tem sua história ligada à neta de John Kenworthy, Olga Kenworthy. Nascida em Sorocaba, foi educada pelos familiares britânicos e estudou em São Paulo, onde conheceu seu marido, Bráulio Guedes da Silva. Casada, morou em São Paulo por um breve período, mas retornou à Sorocaba.

Bráulio assume a direção da Fábrica Santa Rosália, juntamente com Hélio Monzoni, no período em que ela se tornou sociedade anônima (década de 1910) e a CNE passou a ser a sócia majoritária daquela indústria. É justamente nesta época que Guedes da Silva adquire uma gleba de terras na área rural da cidade onde edificou um casarão em estilo inglês, sendo todos os materiais importados da Inglaterra. Lá deu o nome de Granja Olga em homenagem à sua esposa. Neste local nasceram e se criaram seus três filhos, Mário, Frank e Daniel.

Após a morte dos pais, os dois filhos (Daniel morreu ainda jovem, vítima de um acidente doméstico) herdaram a propriedade, que com o crescimento da cidade, já se encontrava dentro do perímetro urbano de Sorocaba. Com os altos custos tributários, se viram na contingência de vender a área. Acabaram se associando a um primo e decidiram lotear o local. Trata-se do loteamento fechado Residencial Granja Olga, um dos maiores e mais populosos "condomínios" da cidade de Sorocaba (hoje composto 
pelos Residenciais Granja Olga I, II e III, sendo o I vizinho do II, e estes separados do III pela via férrea da antiga EFS). A antiga sede da fazenda está preservada, contudo inserida dentro de um lote padrão, camuflando-se em meio às outras casas, perdendo totalmente sua ambiência. Todas as outras construções rurais foram demolidas, exceto duas construções em tijolos aparentes que hoje estão inseridas no meio do bosque/pista de caminhada, cercadas por uma grande massa arbórea juntamente com um córrego e lago, onde se concentram os equipamentos de uso público do residencial. Estas construções estão em ruínas, sendo uma delas, aparentemente uma pequena casa e a outra uma construção de apoio às atividades da fazenda, contendo silos e local de armazenamento de ferramentas ${ }^{53}$.

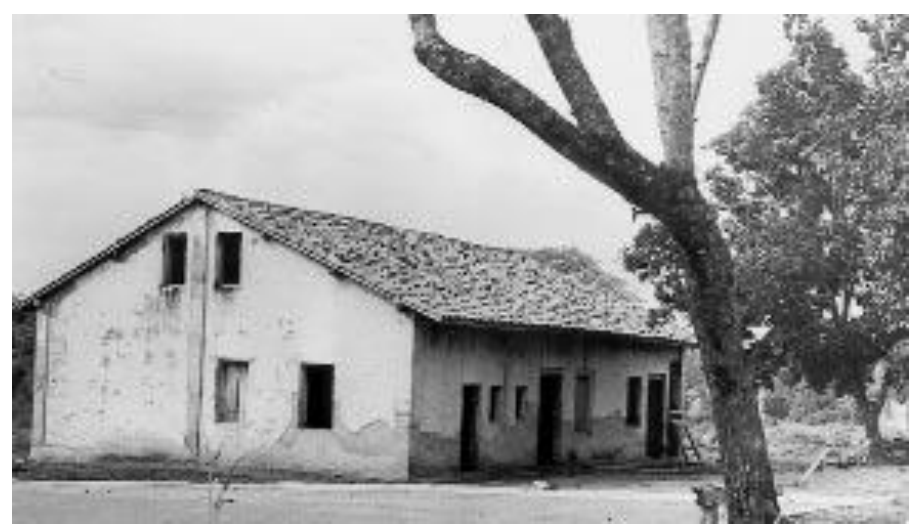

Figura 36: Antiga sede da Granja Olga antes do empreendimento Residencial Granja Olga. Fonte: JORNAL CRUZEIRO DO SUL, 23.05.2000, p. A-6

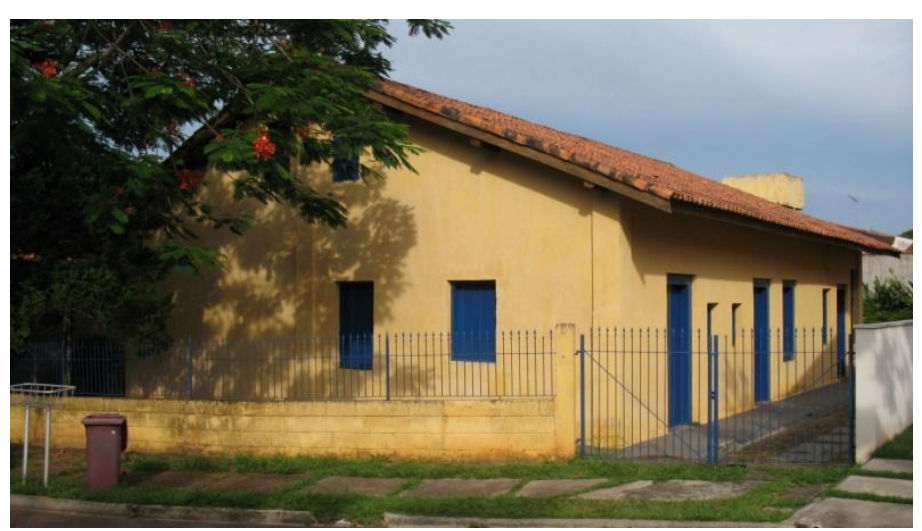

Figura 37: Estado atual da antiga sede da Granja Olga, inserida dentro de um lote comum dentro do condomínio. Fonte: do autor.

\footnotetext{
${ }^{53}$ Agradeço ao Dr. Gustavo Puglia Martins, por ter facilitado meu acesso aos locais em questão.
} 


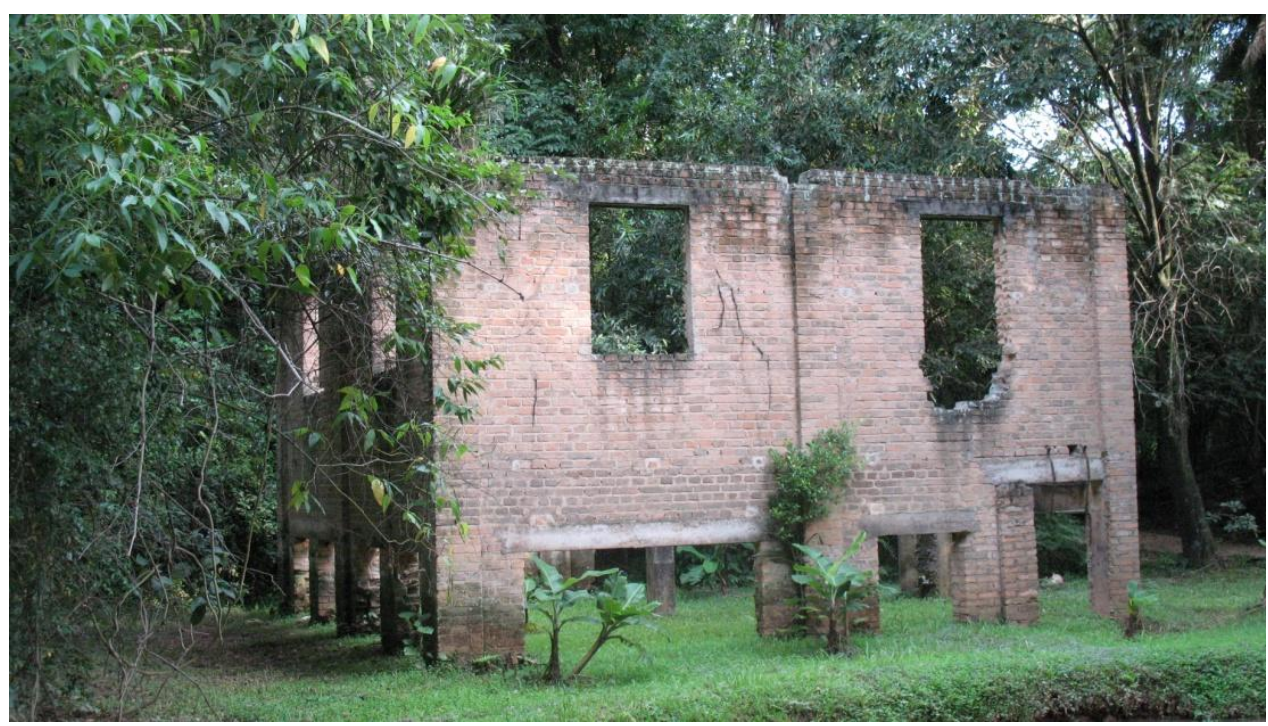

Figura 38: Ruínas de uma antiga residência rural, hoje dentro do bosque do Residencial Granja Olga. Fonte: do autor.

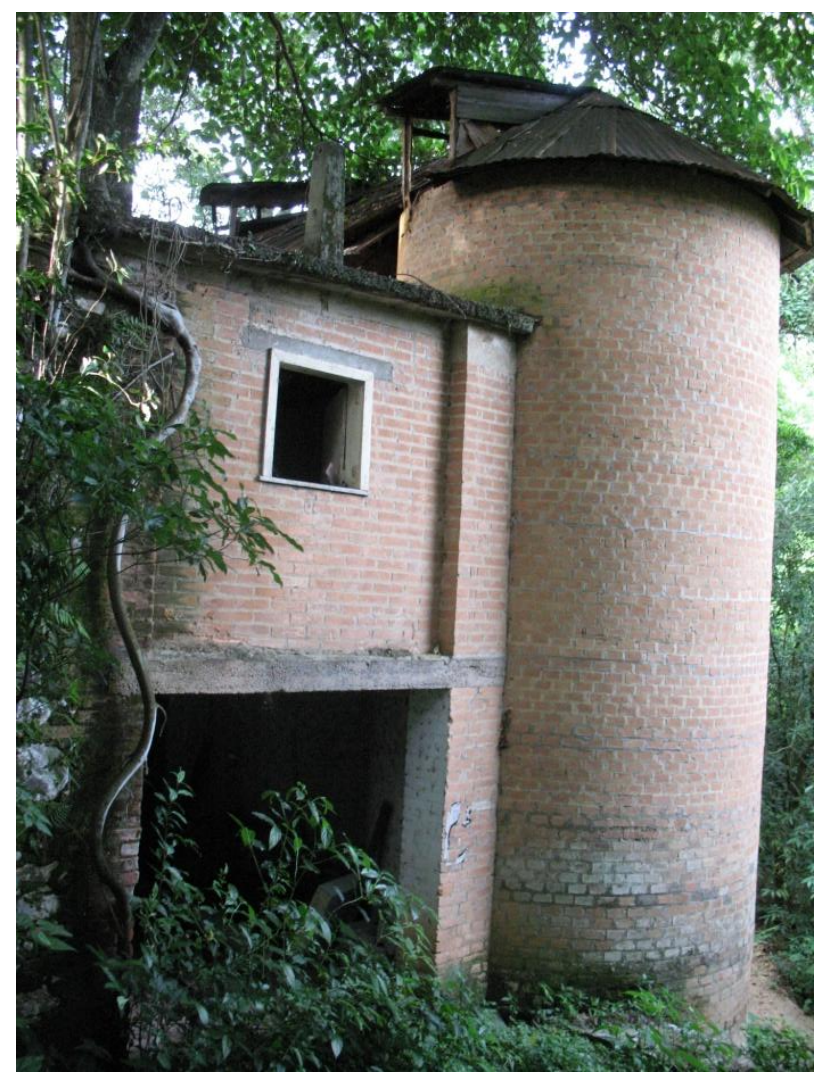

Figura 39: Ruínas de um antigo silo de armazenamento, hoje também dentro do bosque do Residencial Granja Olga. Fonte: do autor. 


\section{A Gestão Pereira da Silva}

Assim como no caso dos Kenworthy é importante entender como Pereira da Silva adquiriu a Fábrica Santa Rosália, juntamente com toda a CNE.

Severino Pereira da Silva nasceu em 6 de maio de 1895, em Taguatinga do Norte (PE) e notabilizou-se por ter se tornado um empresário destacado. Proveniente de família humilde, teve trajetória ascendente, tanto em seu estado de origem quanto no Rio de Janeiro, onde de caixeiro viajante chega a industrial.

Morando no Rio de Janeiro, envolto nas matrizes dos bancos e grandes indústrias têxteis, Severino acabou adquirindo grande conhecimento a respeito do mercado internacional têxtil, em que viu uma grande possibilidade de lucros para a empresa na qual trabalhava (Alves de Brito e Cia). Implantou na companhia um setor de importações, que the conferiu grande destaque.

Após 15 anos à frente da Alves de Brito e Cia. do Rio de Janeiro, Pereira da Silva teve a oportunidade de adquirir a Fábrica de tecidos Sapopemba, no distrito de Deodoro no Rio de Janeiro, propiciada pelo conturbado cenário político devido à entrada de Vargas no poder, quando muitas fábricas se endividaram e acabaram passando para as mãos dos bancos.

Com o sucesso desse negócio, graças a sua capacidade empreendedora, Pereira da Silva comprou a Companhia Manufatura Fluminense Niterói.

Entre seus empreendimentos, destaca-se também um grande loteamento, com 1000 lotes e 13 edifícios residenciais com os modernos padrões de higiene, saneamento e salubridade, um empreendimento inovador naqueles anos. Trata-se do bairro Jardim 
Laranjeiras, onde os edifícios receberam nomes de cidades pernambucanas e puderam ser adquiridos mediante financiamento da Caixa Econômica Federal ${ }^{54}$.

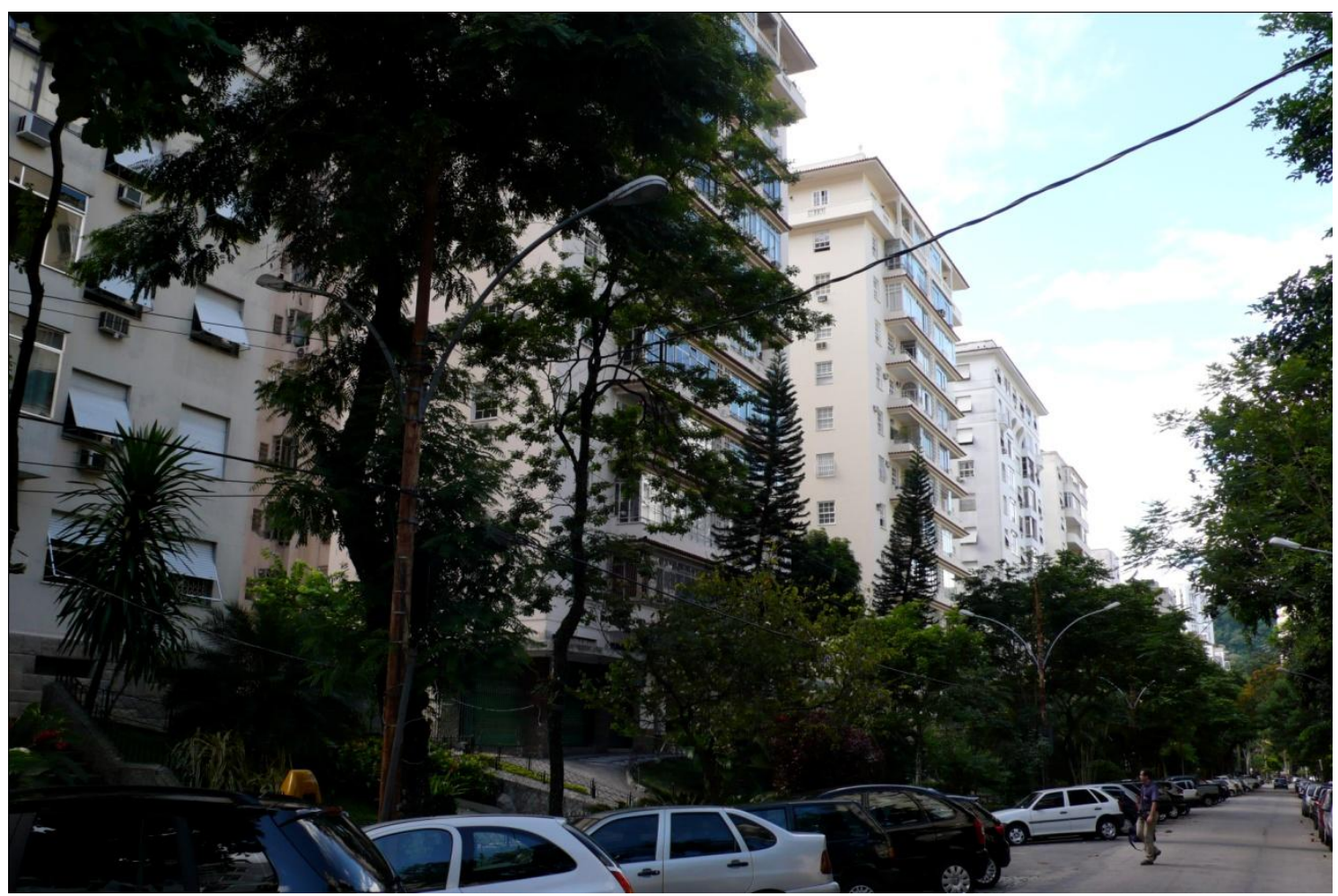

Figura 40: Vistas da Rua General Glicério, Jardim Laranjeiras, Rio de Janeiro/RJ, 2010. Fotos de Gustavo Weiss D. Nogueira. Fonte: do autor.

\begin{abstract}
"Papai, tendo em mãos capital acumulado das fábricas Sapopemba e Fluminense, loteou toda a área da Aliança em 1000 lotes e 13 edifícios residenciais com 11 andares cada [...] Veja só a grandeza desse empreendimento, no final dos anos 30, veja quanto dinheiro meu velho tinha nessa época" ${ }^{55}$.
\end{abstract}

Sua transferência para Sorocaba, em 1939, deveu-se à oportunidade de compra da CNE - Companhia Nacional de Estamparia, e um ano depois da Fábrica de Tecidos Santa Rosália. Fato curioso é que Getulio Vargas esteve em Sorocaba, com a finalidade

\footnotetext{
54 Agradeço ao amigo Gustavo Weiss Deleu Nogueira pelo inestimável e detalhado levantamento fotográfico dos edifícios do Parque das Laranjeiras.

${ }^{55}$ Depoimento de Carlos Alberto M. Pereira da Silva, IN: SILVA, Wesley Carlos da. Op. Cit. p. 50.
} 
exclusiva de visitar as instalações da fábrica e do bairro operário de Santa Rosália, em 09/01/1940, conforme consta no livro de Wesley Carlos da Silva:

\begin{abstract}
“Em 09 de janeiro de 1940, em visita a Sorocaba e região, o presidente Getulio Vargas visitou a vila industrial de Santa Rosália, conhecendo os trabalhos da Escola Maternal. Segundo o Jornal Cruzeiro do Sul, o presidente fez muitos elogios aos trabalhos executados com as crianças e a Companhia que mantinha a escola" ${ }^{56}$.
\end{abstract}

A partir de 11 de dezembro de 1940, Pereira da Silva passou o proprietário de todo o patrimônio da Companhia, que naquele momento era constituída pelas fábricas: Alvejaria, Tinturaria e Estamparia São Paulo, Fábrica de tecidos Santo Antônio, Fábrica de Tecidos Santa Rosália, Usina de Energia de Pilar do Sul e outras propriedades rurais. A fábrica Santa Maria não fez parte do negócio, pois apesar de trabalhar junto com as outras unidades da CNE, pertencia a outra companhia, de propriedade de filhos e genros de John Kenworthy. A partir de então a CNE começou uma nova fase em Sorocaba.

O ano de 1941 marca o início da gestão Pereira da Silva. Seu primeiro desafio foi garantir aos funcionários padrões de higiene, saneamento, salubridade e habitabilidade na vila operária, que passava por um grande surto de malária, causando muitas baixas no número de funcionários, que afetavam o nível da produção. 0 projeto de saneamento teve início com a limpeza das margens dos rios, poda de árvores, transporte de lixo locais apropriados e estendeu-se para Um projeto de implantação de rede de água e esgoto e uma reforma e ampliação da vila operária de Santa Rosália, que até então não contava com estes serviços, tampouco possuíam banheiro, como já mencionamos.

Favorecido pela precária situação da Europa durante a segunda guerra, sua fábrica chegou a empregar oito mil funcionários ${ }^{57}$.

\footnotetext{
${ }^{56}$ SILVA, Wesley Carlos da. Cianê: auge, decadência e outras histórias. Sorocaba, SP: do autor, 2009, p.56.

${ }^{57}$ FUNDAÇÃO UBALDINO DO AMARAL. Sorocaba 350 Anos. Suplemento do Jornal Cruzeiro do Sul, Sorocaba, 15.8.2004, p.34.
} 
Passou a exportar tecidos para a África do Sul, Índia e Indonésia, mercados que não estavam sendo explorados devido à guerra. Durante todo o período de guerra a CNE exportou muito, obtendo muitos lucros, que foram usados na Modernização dos teares, que até então eram mecânicos, sendo movidos pelo maquinário conhecido como "locomóvel" que ficava localizado na chamada "capelinha", na entrada da fábrica (onde hoje é a entrada principal do hipermercado Extra). Com isso, a Usina de Pilar do Sul também precisou ser modernizada para suprir as novas demandas de energia.

Foi neste dinâmico período que grande parte das benfeitorias foram realizadas, chegando a CNE fazer o papel de Estado, tal o nível de investimentos urbanos realizados, como: Instalação de um sistema de saneamento básico com nova rede de água e esgoto, pavimentação das ruas existentes, implantação de um hospital operário (São Severino) - mantido com recursos da empresa, subsidio à compra de gêneros alimentícios, de higiene e medicamentos (através do armazém do SESI, do açougue e da farmácia do bairro), educação aos filhos dos funcionários em todos os níveis escolares - da creche ao ensino profissionalizante (escola Senai), lazer (através do grupo musical, do Grêmio e do clube Fortaleza, posteriormente ampliado com o Estádio Severino Pereira da Silva) e cultura - com o cine-teatro Santa Rosália, além de igreja, praças e posteriormente luz elétrica e a construção de 399 novas casas operárias.

\section{O Hospital São Severino}

Construído em $1943^{58}$, o Hospital São Severino prestou serviços aos funcionários da CNE durante 30 anos, tendo fechado suas portas no início da década de 1980.

O conjunto dos edifícios era formado pelo bloco principal, centralizado e com recuos frontais e laterais, composto de quatro alas e um pátio interno, onde se localizavam os quartos e salas de atendimento. Nos fundos do terreno havia outro bloco separado onde eram internados os pacientes com doenças infecto-contagiosas. Na lateral

\footnotetext{
${ }^{58}$ FIOROTTO FILHO. Op. Cit, p.74.
} 
esquerda do prédio principal localizava-se a Capela do Hospital, juntamente com o edifício de apoio onde as madres voluntárias descansavam. Também em edifícios separados do bloco principal estavam o necrotério, a lavanderia, a cozinha e a garagem das ambulâncias. Todas as construções apresentavam características neocoloniais, sendo os edifícios compostos de alvenaria de tijolos auto portantes, janelas compostas por vitrôs de ferro e vidro, com peitoris de cerâmica, cobertura em telhado formado por telhas de capa e canal. A edificação principal ainda apresentava um frontão curvo onde era possível avistar o nome do local.

Foi um hospital particular e que atendia gratuitamente aos funcionários e dependentes dos mesmos, até o seu fechamento. Fechou devido à má situação financeira (poucos atendimentos particulares, muitos atendimentos à pacientes do SUS e aos funcionários e dependentes); descompasso entre verbas recebidas e custos de funcionamento. Ficou abandonado e inutilizado por mais de 15 anos. Tinha dívidas públicas e foi comprado pela Prefeitura tendo inicialmente o planejamento de ser um hospital municipal, na gestão do Prefeito Paulo Mendes (1993-1996). Estudos da Prefeitura local demonstraram que teria melhor destinação para a população se viesse a ser uma policlínica, face aos grandes investimentos que seriam necessários para adequar o prédio, dentro das normas técnicas exigidas na ocasião, relacionadas à higiene, saneamento e controle de infecções. Essa decisão de uso como policlínica foi tomada pela impossibilidade de desfazer a compra do imóvel. Foram feitos alguns reparos e a mudança de uso: ao invés de hospital, o recinto seria utilizado como uma clínica municipal para atendimentos com especialistas, passando a se chamar Policlínica Municipal Dr. Edward Maluf, onde atualmente são oferecidos atendimentos às principais especialidades, bem como a realização de alguns tipos de exames subsidiários (Raios X, Ultrassom, exames laboratoriais, etc.). 


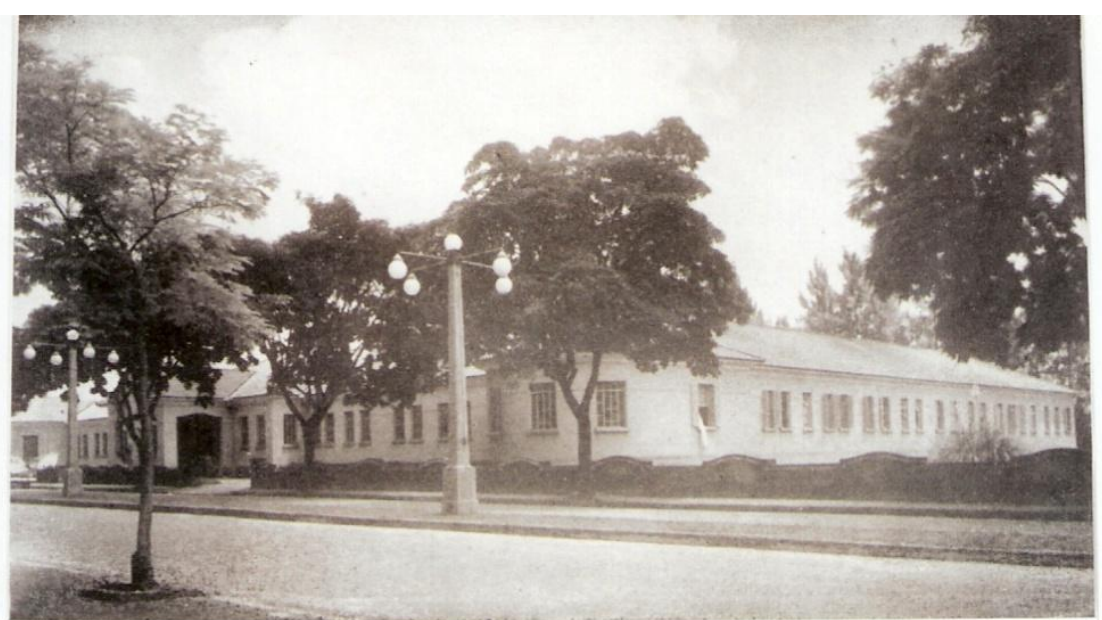

\section{HOSPITAL S. SEVERINO}

Figura 41: Hospital São Severino, 1959. Fonte: CIA. NACIONAL DE ESTAMPARIA - 50 ANIVERSÁRIO, SOROCABA. Magazine das Nações. Ano 12 - Edição Especial. Editora e Publicidade Roman Ltda., São Paulo, Maio de 1960. Acervo do autor.

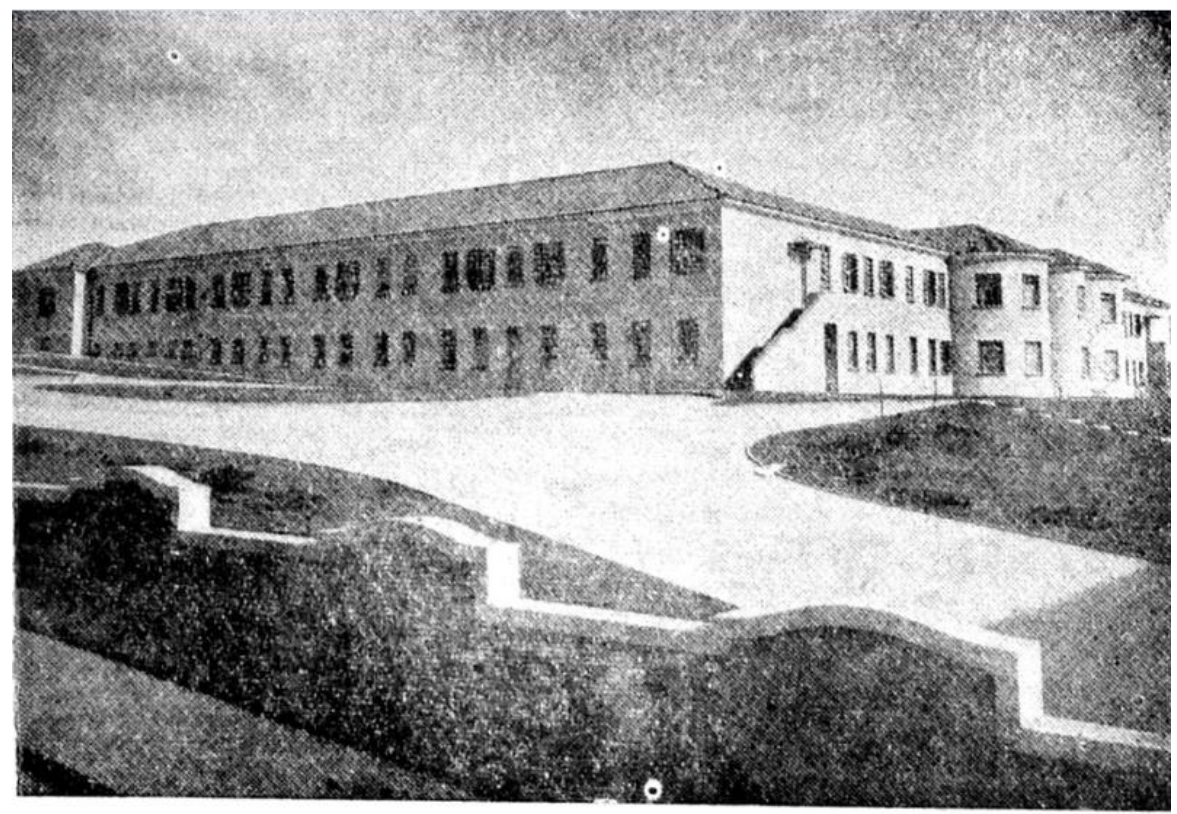

NO HOSPITAL S. SEVERINO OS OPERARIOS SAO INTERNADOS GRATUITAMENTE

Figura 42: Hospital São Severino, vista posterior, 1948. Fonte: Jornal Cruzeiro do Sul. 14.3.1948, p. 4. 


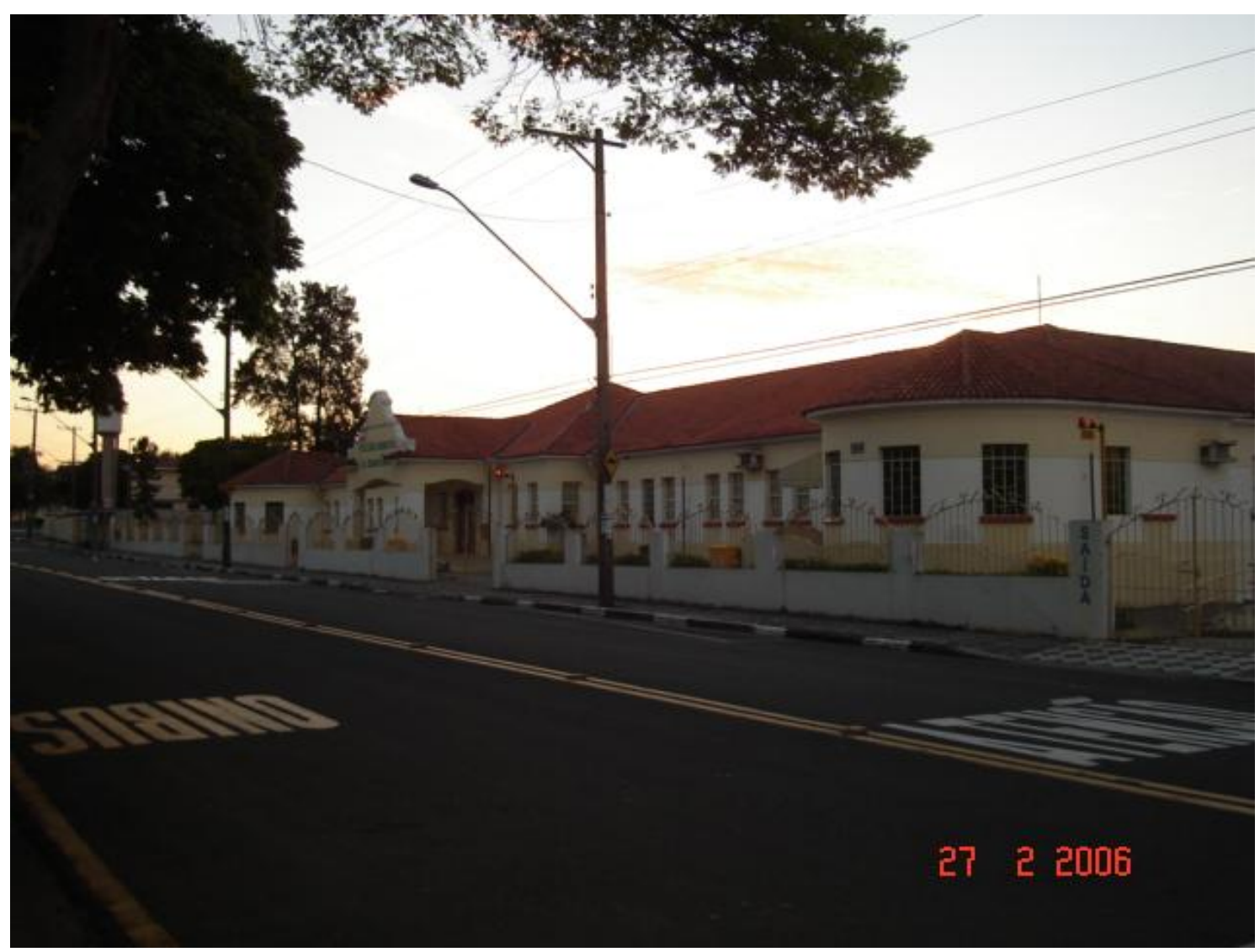

Figura 43: Hospital São Severino, 2006. Fonte: do autor.

Sua situação atual nos faz considerar tratar-se de bem sucedida intervenção cujo uso atual do prédio é compatível e próximo do original.

\section{Posto de Abastecimento (SESI); Açougue; Farmácia; Loja da Fábrica}

O posto de abastecimento (armazém), localizado na lateral da Praça Pio XII, era responsável pelo fornecimento de gêneros alimentícios aos funcionários da fábrica. Essa facilidade foi possível através de uma parceria estabelecida dentre a CNE e o SESI, onde a contrapartida era a da Companhia manter preços acessíveis para seus operários.

Assim como o posto de abastecimento (na verdade ao lado dele), a CNE também mantinha um açougue, uma farmácia e uma loja que vendia os produtos fabricados a preços baixos, também com o objetivo de suprir o fornecimento de necessidades 
básicas sem que o funcionário necessitasse sair da vila, que dista pouco mais de três quilômetros do centro de Sorocaba ${ }^{59}$.

Há pouquíssimos registros fotográficos destes imóveis. Inclusive não há uma descrição dos mesmos estabelecendo a data de construção/inauguração. Dentre estas poucas fotos, todas são do período da administração Pereira da Silva.

Atualmente o conjunto das edificações continua com um uso comercial.

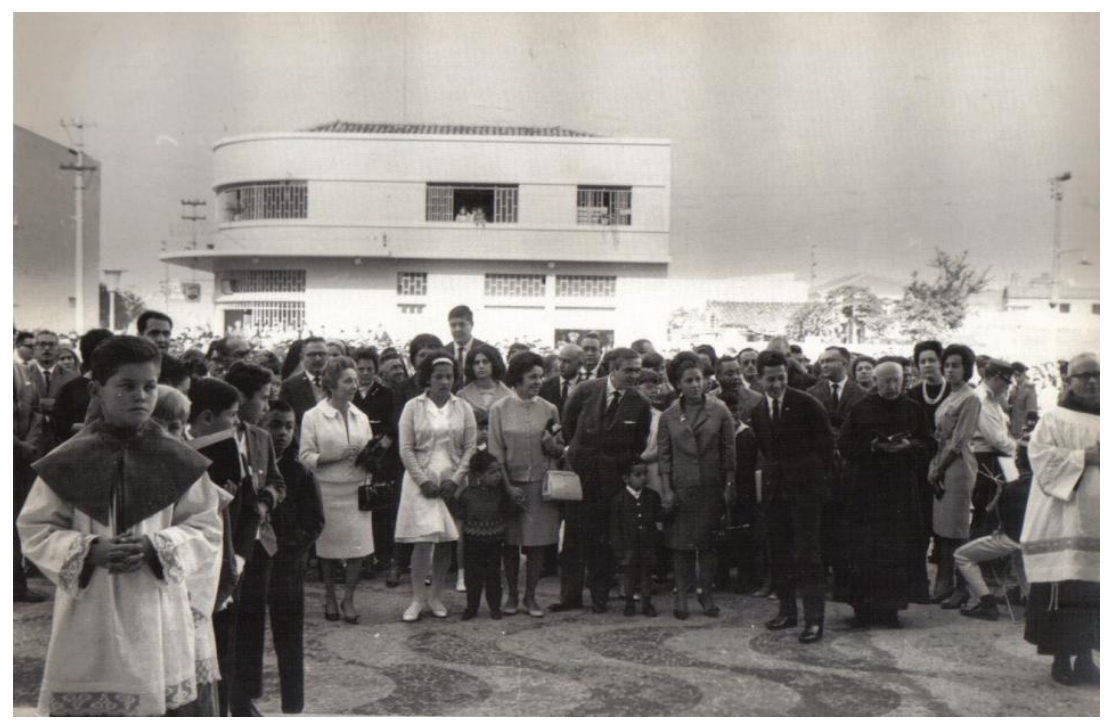

Figura 44: Postos de abastecimento da vila de Santa Rosália, 1960. Fonte: Albúm Comemorativo da Inauguração da Igreja de Santa Rosália - Homenagem dos Diretores e Funcionários da Cia. Nacional de estamparia ao Sr. e Sra. Carlos Alberto Moura Pereira da Silva, p. 47. Acervo de Wesley Carlos da Silva.

\footnotetext{
59 JORNAL CRUZEIRO DO SUL. 14.3.1948, p. 4.
} 


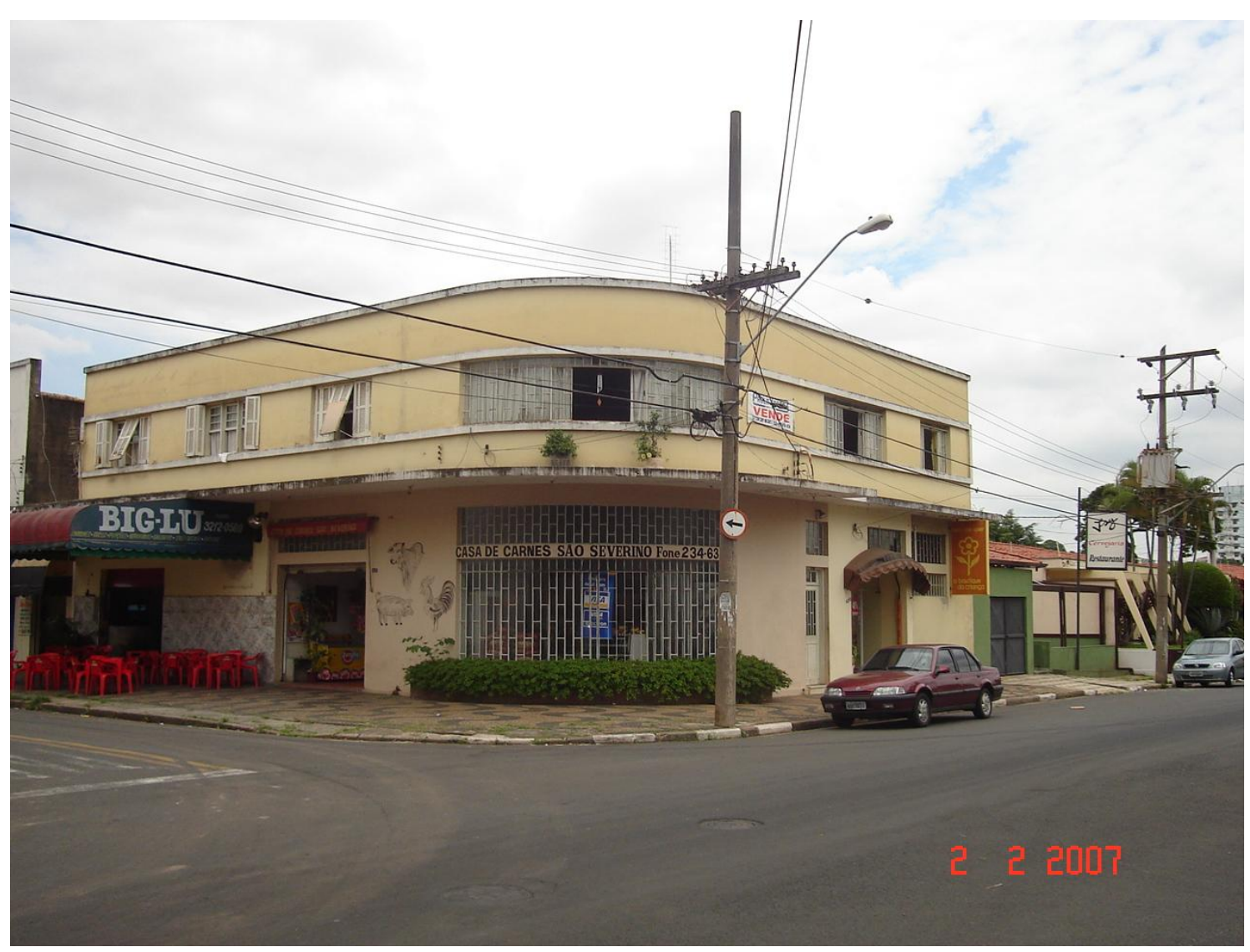

Figura 45: Edifício dos antigos postos de abastecimento da vila de Santa Rosália, atualmente. Fonte: do autor, 2006.

\section{Ginásio}

Logo após a compra da Fábrica Santa Rosália, em 1939, pelo Pereira da Silva, um plano de expansão da vila operária é iniciado, juntamente com a melhoria e expansão dos benefícios cedidos aos funcionários. Com isso, decide-se que a Escola Maternal iria dar lugar ao curso ginasial. Em 1942 era inaugurada a Escola Ginasial. O edifício da escola fora demolido, juntamente com algumas casas que eram vizinhas à escola. Com isso, o novo prédio recebeu um grande recuo frontal, onde eram realizadas atividades físicas, assim como um recuo lateral e um pequeno muro. Estruturado em três alas de salas de aula separadas por pátios internos.

No início da década de 1980 fora transformado em Ginásio Estadual “Dr. Arthur Cyrillo Freire", seguindo o mesmo destino do Grupo Escolar - transferência da unidade de ensino para um edifício público e fechamento do prédio. Contudo, ficou abandonado 
por um período maior, sendo demolido em 2007 para a construção de um centro comercial.

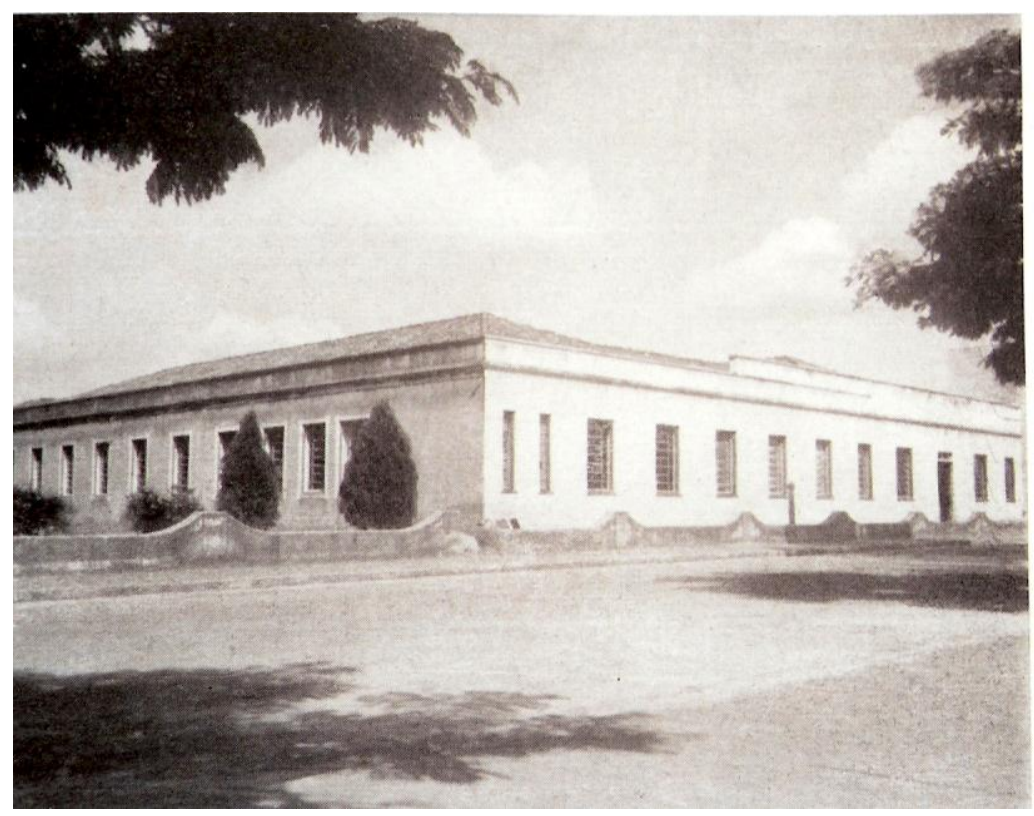

Ginásio.

Figura 46: Ginásio de Santa Rosália, 1959. Fonte: CIA. NACIONAL DE ESTAMPARIA - 50 ANIVERSÁRIO, SOROCABA. Magazine das Nações. Ano 12 - Edição Especial. Editora e Publicidade Roman Ltda., São Paulo, Maio de 1960. Acervo do autor. 


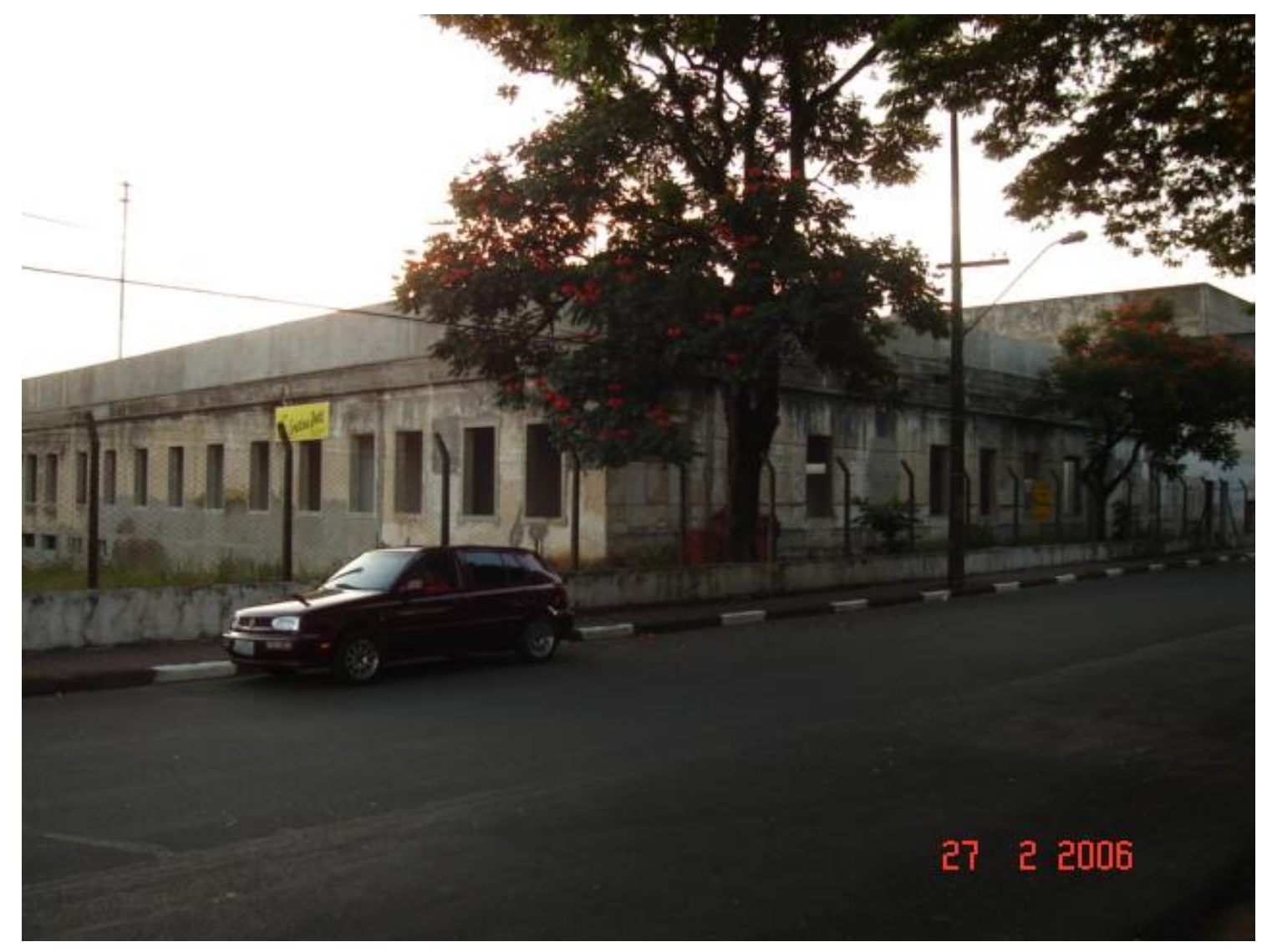

Figura 47: Ginásio de Santa Rosália pouco antes de ser demolido, 2006. Fonte: do autor.

\section{A escola SENAI}

A primeira escola SENAI - Serviço Nacional de Aprendizagem Industrial de Sorocaba funcionou provisoriamente durante um período de 11 anos (de 1943 até 1954) em um edifício já existente na vila operária da Fábrica Santo Antonio, localizado na Rua Dom Antônio Alvarenga. Seus cursos profissionalizantes eram todos voltados para a indústria têxtil (fiação, tecelagem e estamparia), além de cursos de metrologia, desenho técnico e mecânico e manutenção de maquinários têxteis. Seu intuito era oferecer formação adequada aos futuros funcionários, atendendo à demanda das indústrias locais por mão-de-obra qualificada, tanto para a produção, quanto para a manutenção de todo o maquinário utilizado.

Em 16 de Setembro de 1954, Pereira da Silva deu início à construção de uma nova sede para o SENAI, especifica para suas funções, na própria Avenida Pereira da Silva (Santa 
Rosália), concluindo assim o ciclo educacional da vila operária (creche, escola maternal, escola primária, ginásio e ensino profissionalizante).

O edifício era composto de três alas de salas de aula avarandadas, intermediadas por dois pátios para recreação. Sem muros ou separações físicas, esse espaço era comumente utilizado pelos moradores locais aos finais de semana para recreação e lazer.

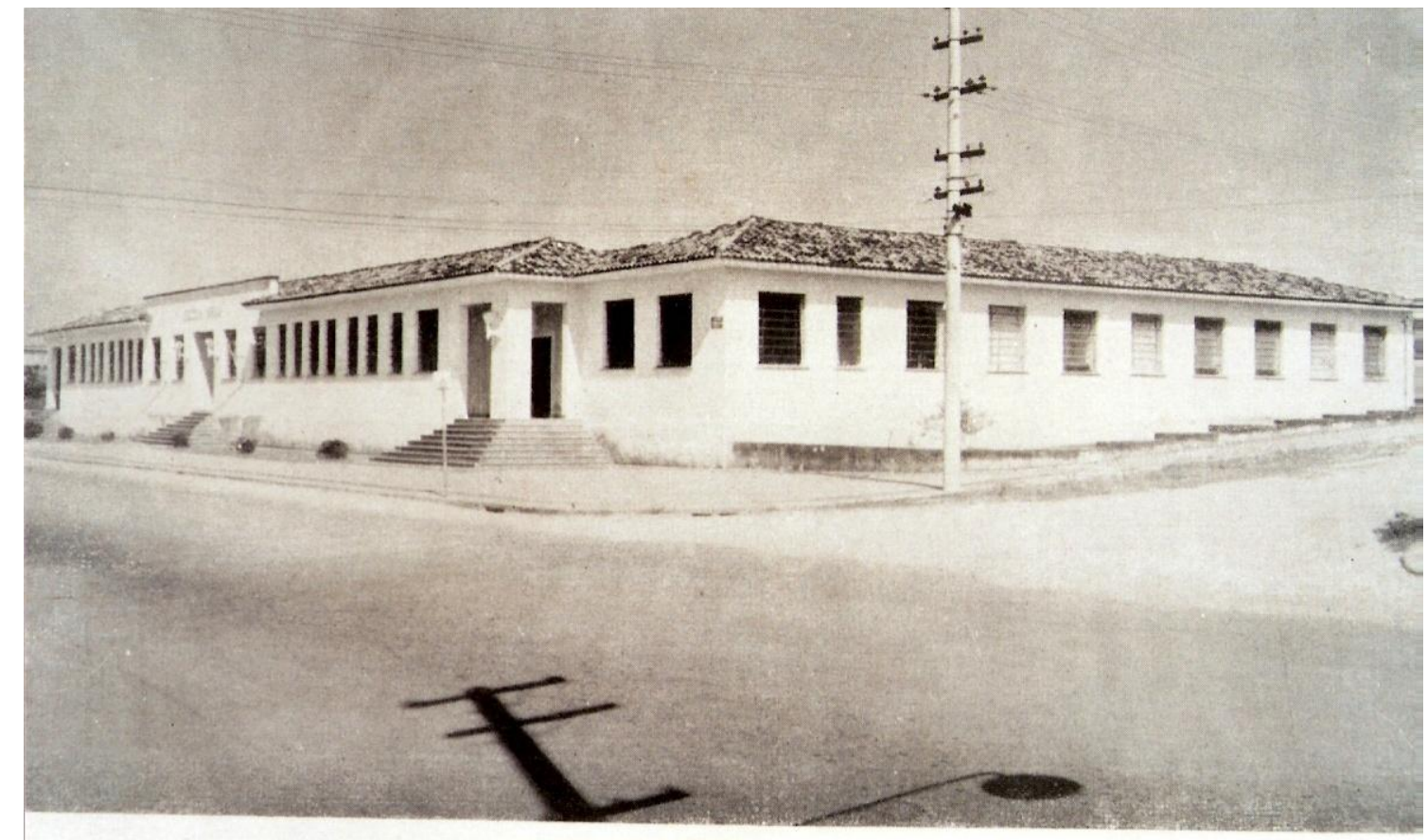

Prédio da Escola SENAI da Companhia Nacional de Estamparia.

Figura 48: Escola SENAI, 1959. Fonte: CIA. NACIONAL DE ESTAMPARIA - 50 ANIVERSÁRIO, SOROCABA. Magazine das Nações. Ano 12 - Edição Especial. Editora e Publicidade Roman Ltda., São Paulo, Maio de 1960. Acervo do autor. 


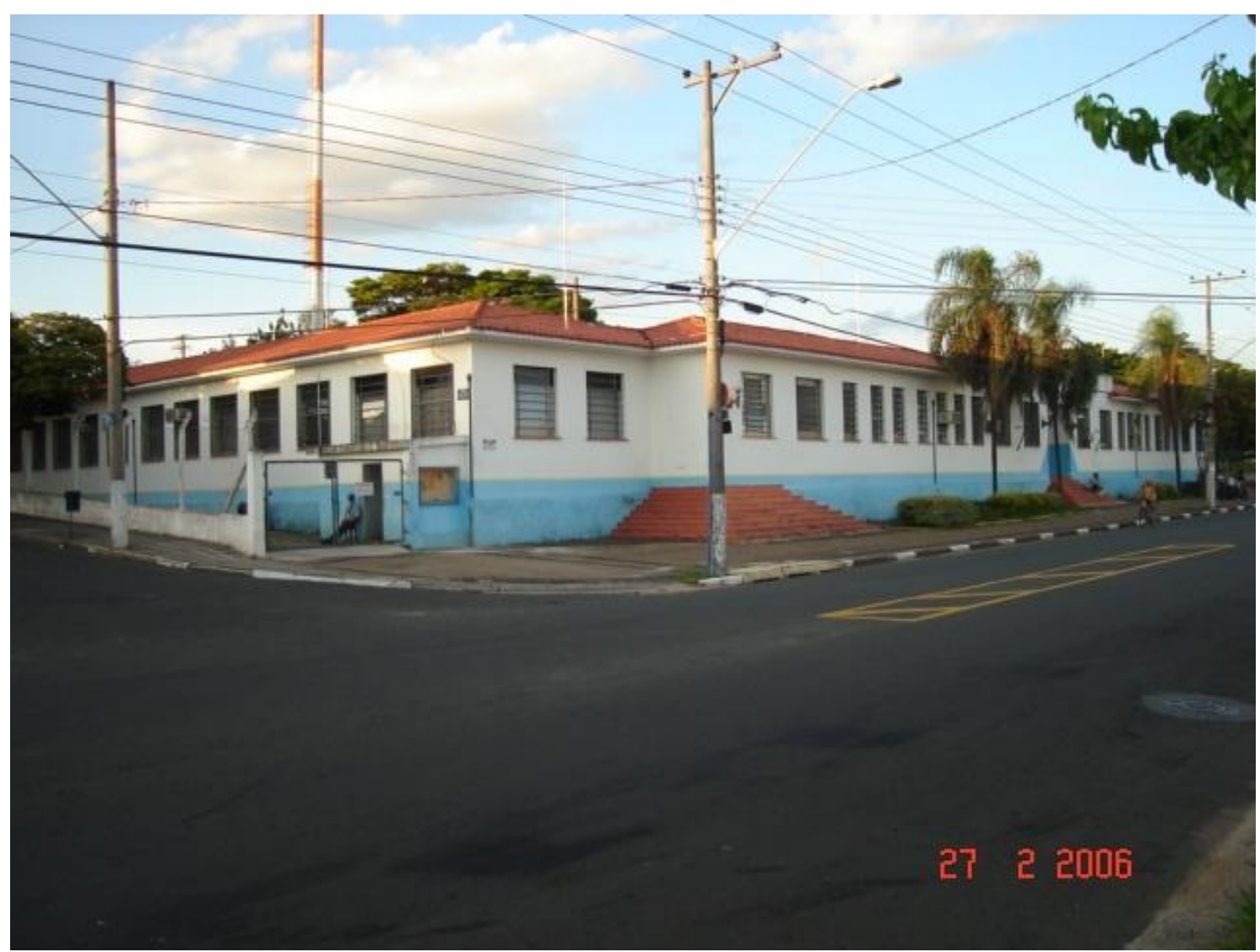

Figura 49: Sede do Serviço Autônomo de Água e Esgoto de Sorocaba, 2006. Fonte: do autor.

Durante mais de duas décadas a escola funcionou neste edifício. Todavia, após a implantação da nova zona industrial na cidade de Sorocaba, a demanda por mão-deobra qualificada forçou o SENAI a investir em novos cursos profissionalizantes, principalmente os voltados para as indústrias químicas, mecânicas e metalúrgicas. Com isso, o edifício original tornou-se obsoleto, não podendo abrigar o maquinário exigido para tais cursos.

Após a doação de um terreno na Avenida Roberto Simonsen pelo próprio Pereira da Silva, o SENAI constrói uma nova sede, mais ampla e adequada às novas demandas, devolvendo o antigo prédio à CNE. Pouco tempo depois a CNE, através de uma parceria com a Prefeitura Municipal de Sorocaba, aluga o prédio para o Serviço Autônomo de Água e Esgoto - SAAE Sorocaba. 


\section{A Nova Igreja de Santa Rosália}

Com o aumento do número de funcionários (a partir de 1940), a Igreja e a Congregação Mariana tornaram-se pequenas para suas atividades, uma vez que a capacidade da antiga igreja girava em torno de 200 fiéis. Tanto que a esposa do Sr. Severino Pereira da Silva, conhecida como Dona Francisca, devota fervorosa de Santa Rosália, clamou a seu marido que tomasse alguma atitude, para que não se tornasse fato comum dois terços dos fiéis operários ficarem sem acomodação.

Em 1960 decidem demolir ambas construções e edificam nova igreja, cujo projeto foi encomendado ao engenheiro da empresa Alir de Biaggi. A nova igreja é finalizada no mesmo ano ampliando a capacidade para 800 pessoas. A Congregação Mariana foi alocada no subsolo da construção.

Este novo edifício tem uma nova relação com a Praça Pio XII, diferente dos outros dois edifícios demolidos. Sua implantação é lateralizada (?) (rever este termo) em relação à praça e sua fachada principal faz frente ao Cine-Teatro e aos antigos: armazém, farmácia e açougue. Seu campanário é um bloco separado do edifício principal, revestido de peças cerâmicas cor de vinho juntamente com uma pele de vidro, onde se pode observar uma série de escadas que dão acesso aos sinos. A distribuição interna da igreja é bastante simplificada, apresentando apenas uma nave com corredor central, com dois lances de bancos cada lado. Sua fachada principal apresenta apenas uma grande porta de entrada central ladeada de ambos os lados por portas menores. As fachadas laterais apresentam delgados rasgos verticais, com fechamentos de vidro, apresentando aberturas basculantes. Sua fachada posterior, atrás do altar, é inteiramente composta por blocos de elementos cerâmicos vazados, proporcionando peculiar iluminação natural ao interior da igreja.

Seu estado atual é bom, sendo que suas únicas alterações foram: a instalação de uma película azul em todos os vidros do edifício, a criação de uma pequena capela lateral ligando o campanário ao corpo da Igreja e a colocação de textura de base acrílica em todas as paredes internas, que antes eram lisas. 


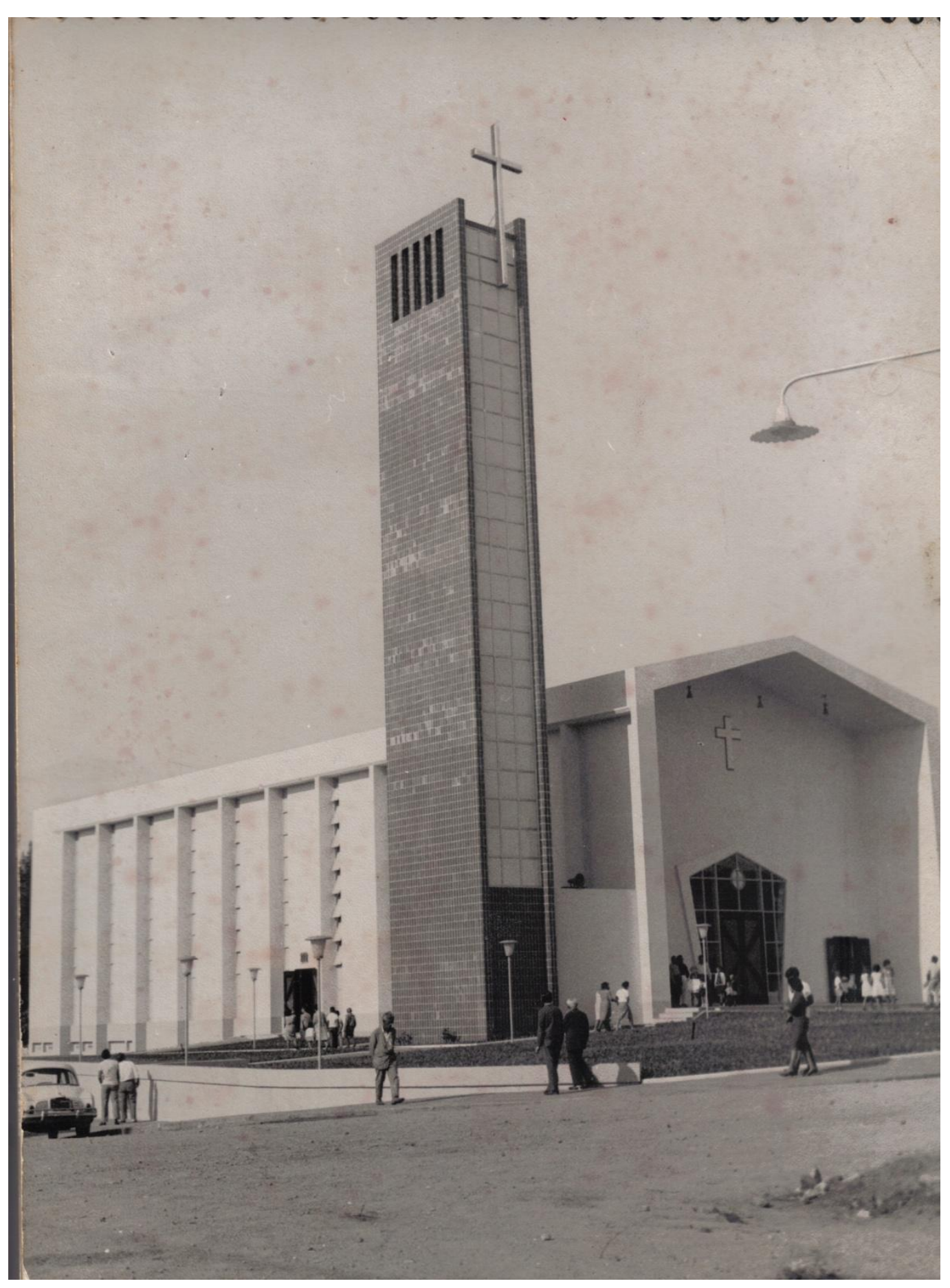

Figura 50: Inauguração da Igreja de Santa Rosália, 1962. Fonte: Albúm fotográfico da inauguração da Igreja. Acervo de Wesley Carlos da Silva. 


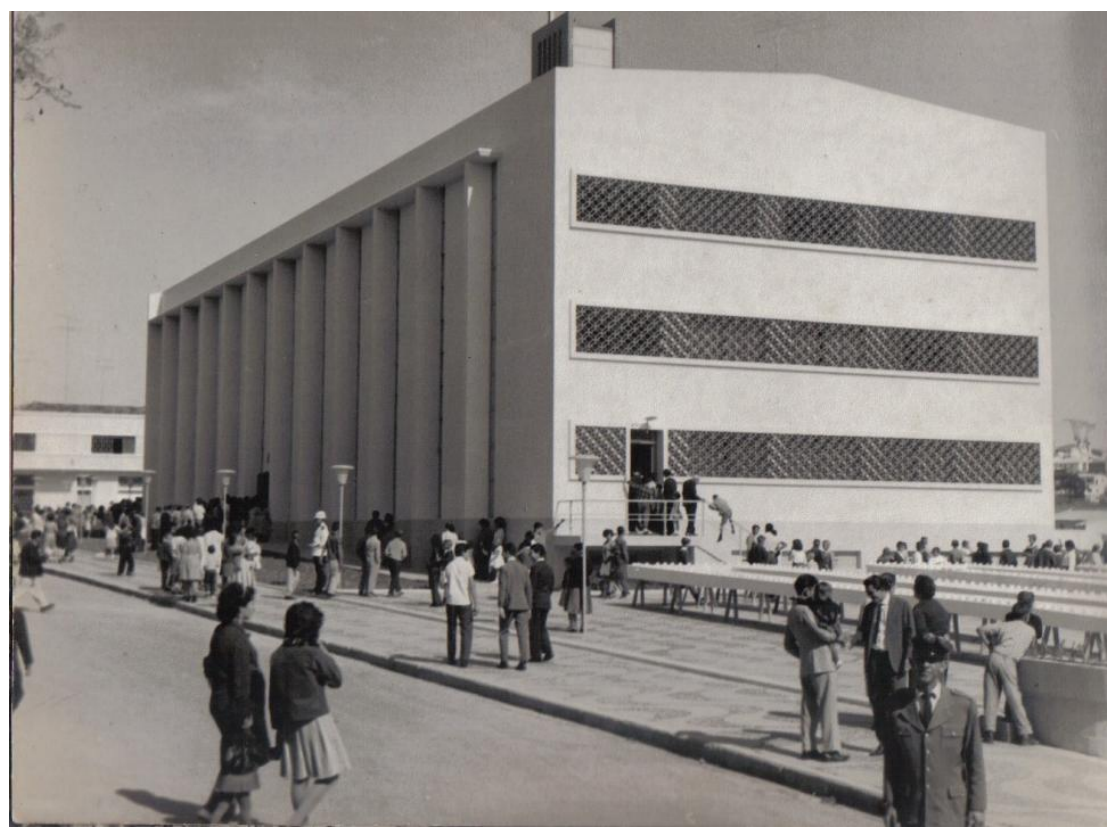

Figura 51: Inauguração da Igreja de Santa Rosália, 1962. Fonte: Albúm fotográfico da inauguração da Igreja. Acervo de Wesley Carlos da Silva.

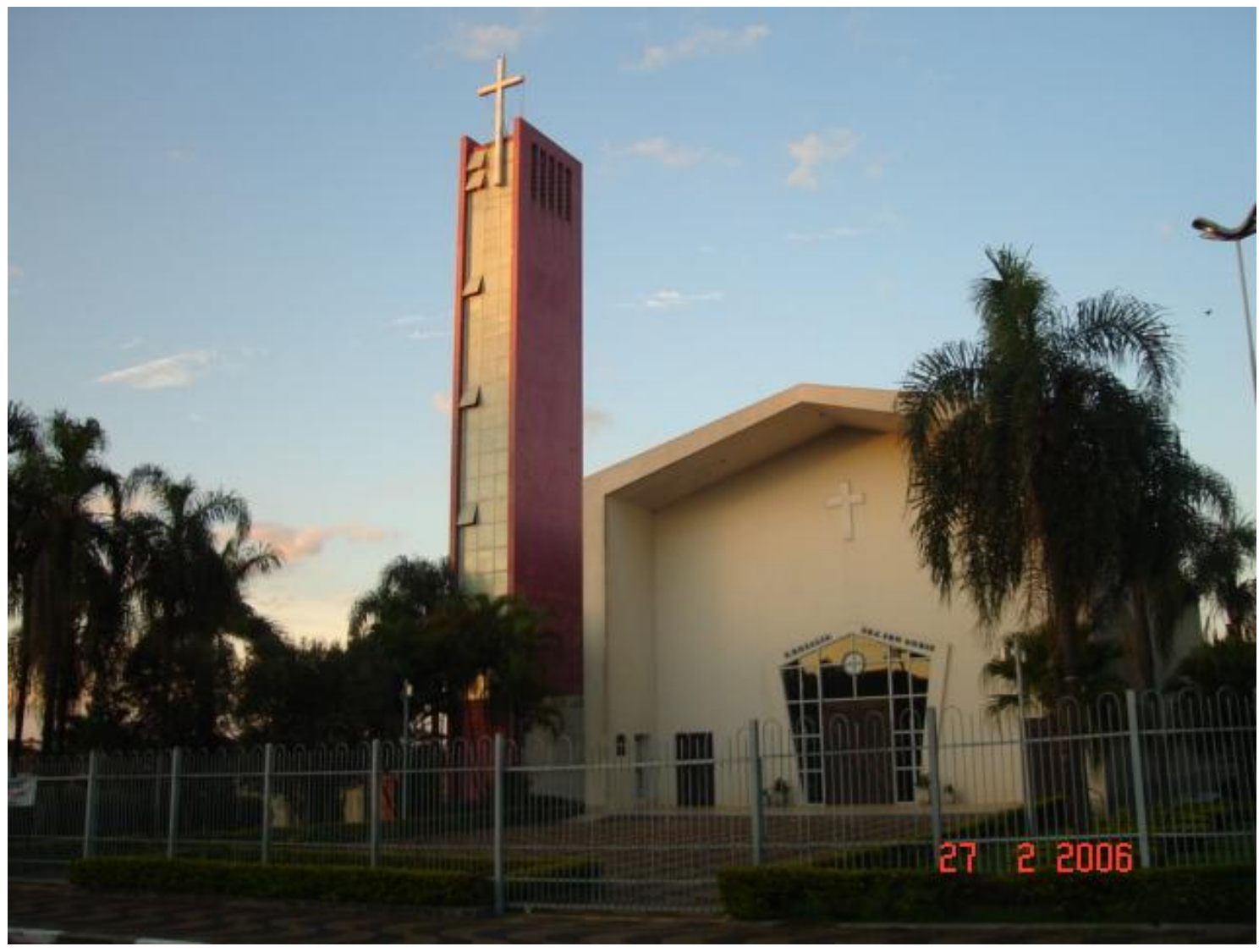

Figura 52: Paróquia de Santa Rosália atualmente. Fonte: do autor. 


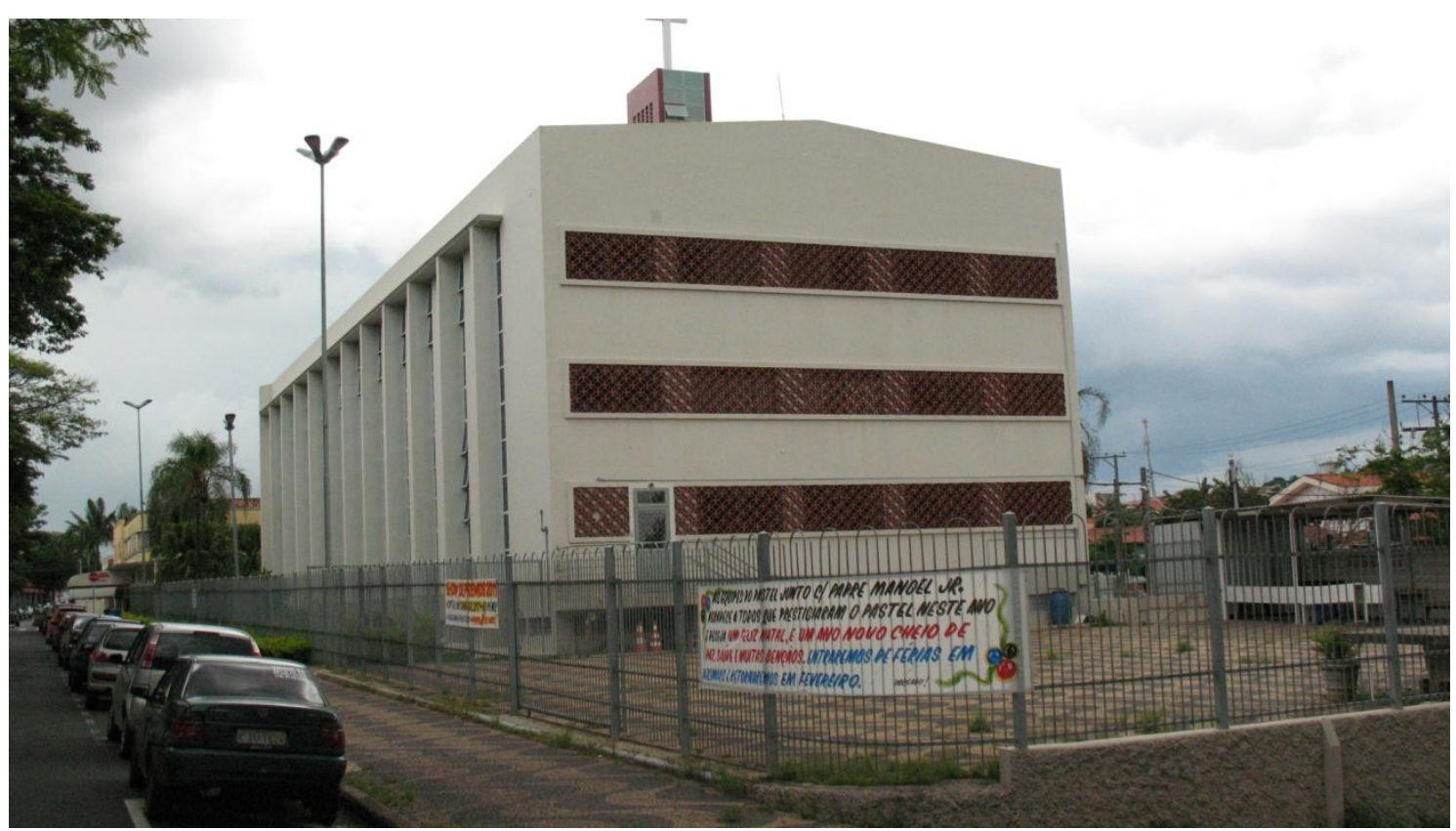

Figura 53: Paróquia de Santa Rosália atualmente. Fonte: do autor.

\section{O estádio Severino Pereira da Silva}

Nos primeiros anos de funcionamento da fábrica Santa Rosália, toda a gerência e controladoria do complexo de fiação e tecelagem eram feitas por engenheiros e técnicos ingleses. $\mathrm{O}$ engenheiro chefe era um jovem conhecido como Mister Klirck (Joseph Klirck). Este rapaz se tornou bastante popular dentre os operários, pois era um excelente jogador de futebol, modalidade esportiva recém chegada ao Brasil. Nas horas vagas procurou introduzir entre os operários a prática do futebol. De início "os jogos eram praticados com uma bola feita de bexiga de boi recoberta com pano grosso e fios de tecelagem" ${ }^{60}$. Esta equipe, em seu início ficou conhecida como Sport Club Santa Rosália. Pouco tempo depois, já com a chegada da bola de couro trazida pelo Mr. Klirck de uma de suas viagens, foi proposta a mudança do nome da equipe para Fortaleza Club, em 24 de junho de 1903. Muitas pessoas aderiram à nova prática e o clube começou a prosperar. Com isso, havia a necessidade de um local mais adequado para as partidas, sendo construído um campo de futebol para os funcionários.

\footnotetext{
${ }^{60}$ FIOROTTO FILHO, Antonio. Aprazível Vila Santa Rosália 1890-2009. Do autor, 2009, p.17.
} 
Até o início da década de 1920 este campo abrigou as partidas do Fortaleza Club. Todavia, nesta época a construção da vila operária primitiva havia sido finalizada e um novo campo foi construído, para que o antigo fosse transformado em praça, a Praça São Carlos (a atual Praça Pio XII). Sua sede social funcionava numa das residências operárias na Rua do Zico (em frente ao portal formado pelas palmeiras imperiais). 0 campo localizava-se nos fundos do Grupo Escolar, tendo como limites a Rua do Zico, a Rua Vicente Lamarca e a Rua São Francisco.

Este novo campo, com a chegada do industrial Pereira da Silva, é transformado em estádio, em 1942, passando a se chamar Estádio Severino Pereira da Silva. Foram construídos os vestiários, arquibancadas cobertas e descobertas, quadras poliesportivas, quadra de tênis, sede social, o fechamento lateral e a entrada principal em formato peculiar, "lembrando uma fortaleza" ${ }^{61}$ (sic).

Este estádio existiu até a década de 1970, quando iniciaram a última etapa do empreendimento Jardim Santa Rosália (lotes). O estádio e as antigas casas da vila primitiva foram demolidos para a ampliação da antiga Rua São Francisco (hoje Avenida São Francisco) e a criação de lotes residenciais para venda.

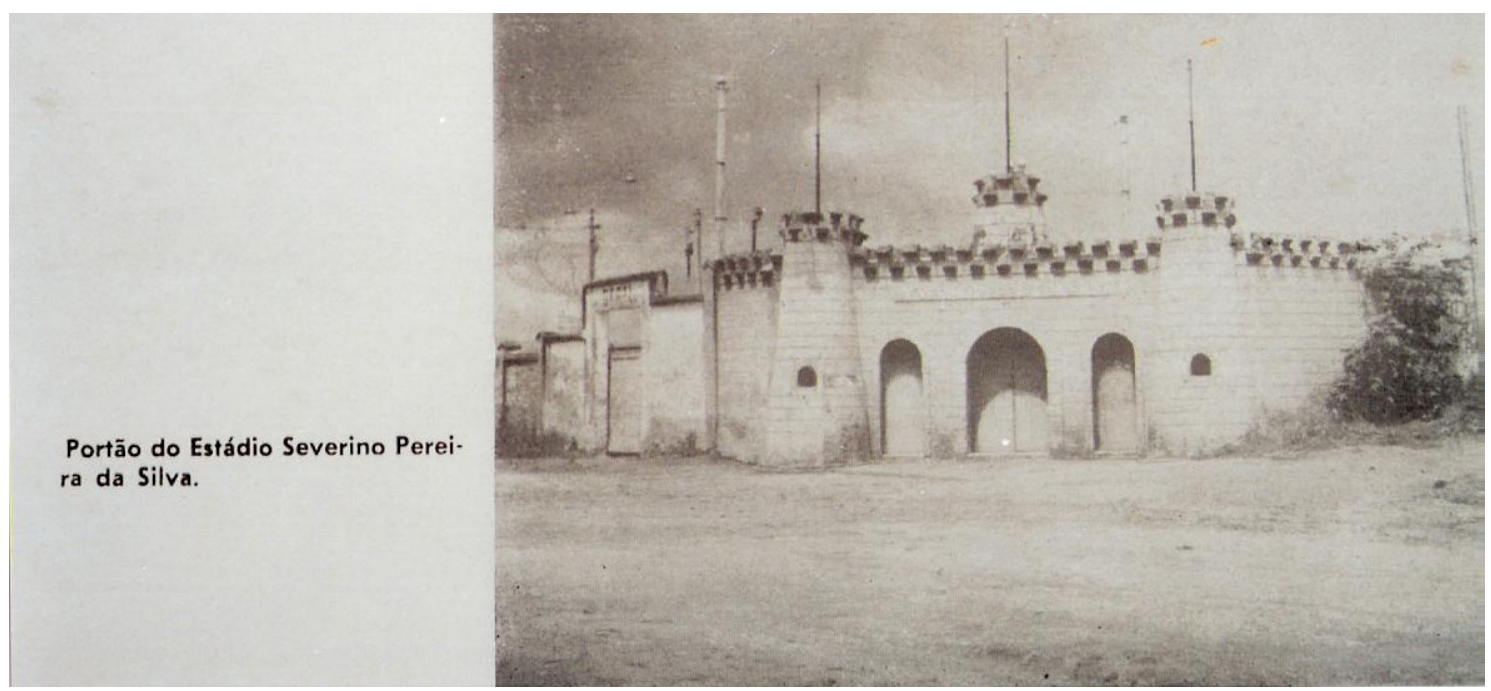

Figura 54: Entrada do Estádio "Severino Pereira da Silva", 1959. Fonte: CIA. NACIONAL DE ESTAMPARIA - 50 ANIVERSÁRIO, SOROCABA. Magazine das Nações. Ano 12 - Edição Especial. Editora e Publicidade Roman Ltda., São Paulo, Maio de 1960. Acervo do autor.

${ }^{61}$ FIOROTTO FILHO Op. Cit, p.19. 


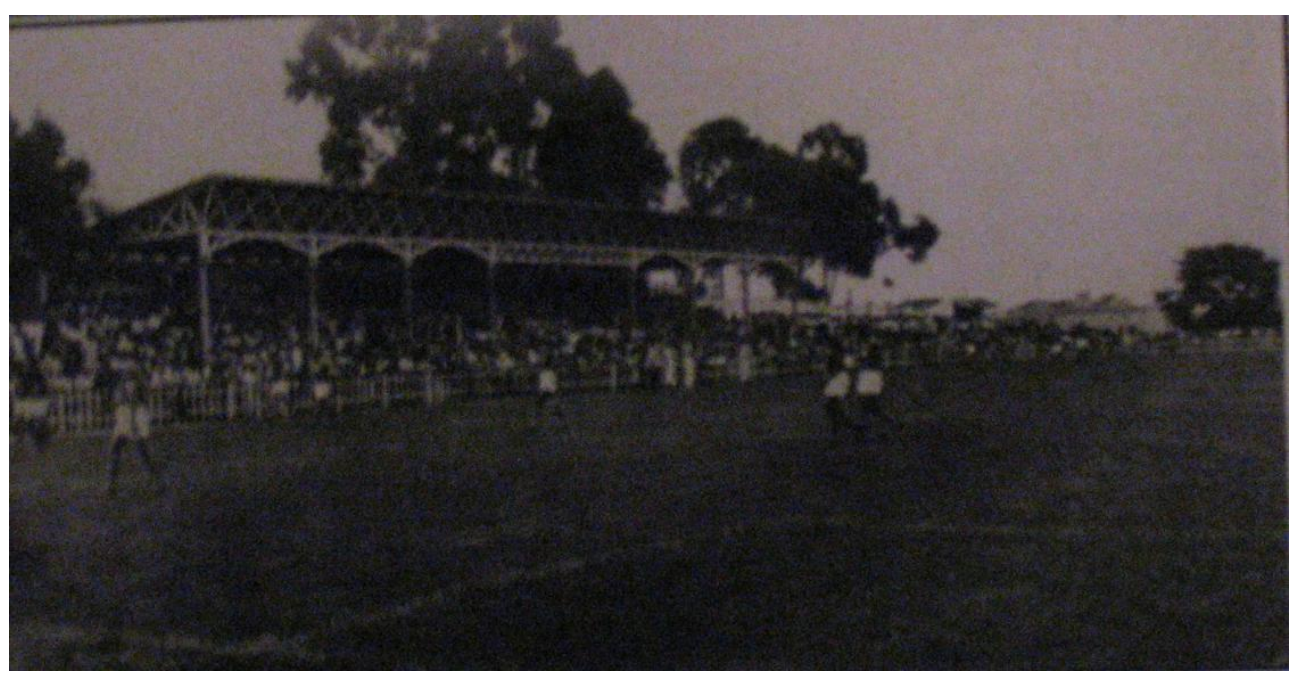

Figura 55: Inauguração do Estádio "Severino Pereira da Silva", 1943 - partida entre o Juventus/SP e o Fortaleza Club. Fonte: Fiorotto Filho, Antonio. Aprazível Vila Santa Rosália 1890-2009. Do autor, 2009, p.21.

\section{O Cine-teatro Santa Rosália}

Inaugurado em 20 de janeiro de 1955, o Cine-teatro de Santa Rosália foi concebido como nova alternativa aos operários. Anteriormente à sua existência, os eventos de projeção de filmes, apresentações musicais e teatrais eram realizadas no salão da Congregação Mariana. Tratava-se do primeiro edifício moderno do bairro. Foi implantado em uma das esquinas da Praça São Carlos, no lugar de algumas residências operárias da primitiva vila, vizinho do edifício do Ginásio. Sua fachada frontal era voltada para a praça, no alinhamento da calçada, apenas com sua entrada principal recuada, marcada pelo terraço apoiado em pilotis, se destacando levemente das demais construções ao seu redor.

"A Companhia Nacional de Estamparia [...] projetou-o com todos os requintes teatrais e pelo seu palco passaram grandes nomes da dramaturgia brasileira, como Procópio Ferreira, Lima Duarte, Paulo Autran, Altair Lima, Juca de Oliveira, Bibi Ferreira entre outros" ${ }^{\prime \prime}$.

Teve suas atividades encerradas em 21 de maio de 1973. O prédio, no entanto, acabou sendo utilizado durante um grande período como uma confecção, pertencente a um dos filhos dos netos de Severino Pereira da Silva. Esta fábrica funcionou até o início dos anos 1990, quando foi desativada juntamente com as outras fábricas do grupo.

\footnotetext{
${ }^{62}$ FIOROTTO FILHO Op. Cit, p.85.
} 
O edifício ficou abandonado durante anos. Em 2007 foi demolido (assim como o Ginásio), para dar lugar a um centro comercial.

\section{O Empreendimento Bairro Santa Rosália (casas e lotes)}

Um dos momentos de maior transformação da Vila/Bairro de Santa Rosália foi o empreendimento Jardim Santa Rosália, iniciado na década de 1950 como um marco no mercado imobiliário da cidade de Sorocaba. Consistia em uma série de casas para a classe média local (com padrão elevado para a época), e posteriormente lotes residenciais para a classe média-alta.

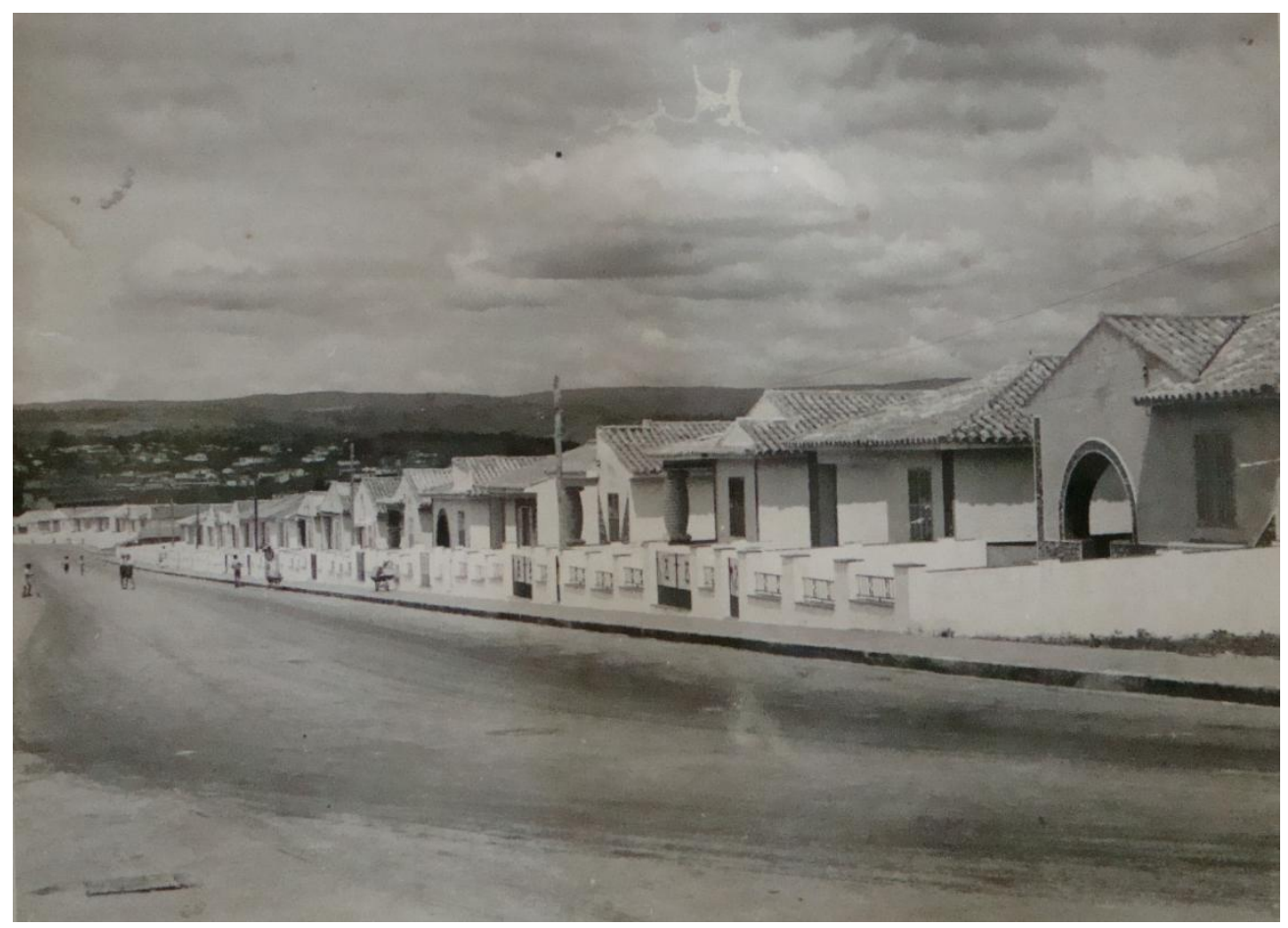

Figura 56: Empreendimento Jardim Santa Rosália - Casas recém-construídas na Avenida Pereira da Silva para venda, década de 1950. Fonte: IHGGS.

Nesta primeira etapa do empreendimento, foram construídas 300 casas de três dormitórios, para venda, ao longo da Avenida Pereira da Silva, da Alameda Kenworthy e da Rua Carlos Malheiros Oetterer. Se somarmos as 400 casas da Vila operária, com as 
300 novas casas do empreendimento, juntamente com as 200 casas da Vila Santo Antonio (pertencente à Companhia), a CNE tornou-se a maior proprietária de imóveis da cidade ${ }^{63}$.

Analisando a trajetória de Pereira da Silva, podemos concluir que o embrião desta bem sucedida ação estava localizado numa outra iniciativa imobiliária que ele havia prosperado, o Bairro Jardim Laranjeiras, no Rio de Janeiro (detalhado anteriormente).

Após a construção das 300 casas em Santa Rosália, a companhia deu início à segunda fase do empreendimento, que consistiu em lotear grande parte do terreno da empresa em 2500 lotes residenciais dotados de toda a infra-estrutura de água, luz elétrica, iluminação pública e esgoto, tornando-se o primeiro bairro da cidade a possuir ruas asfaltadas (até então todas as ruas pavimentadas da cidade eram compostas de calçamentos de pedras - paralelepípedos de granito). Cabe ressaltar que para se construir neste novo loteamento, o proprietário do lote deveria aprovar seu projeto arquitetônico juntamente aos engenheiros da Companhia, que estabeleciam normas e padrões construtivos mais exigentes que a prefeitura da época (aos moldes do que vemos hoje nos loteamentos fechado/ "condomínios") ${ }^{64}$.

Observando o padrão urbanístico do Jardim Laranjeiras, podemos ver inúmeras semelhanças com o Jardim Santa Rosália: recuos frontais e laterais generosos, com grandes áreas ajardinadas, seguindo conceitos de higiene, saneamento e salubridade modernos.

Uma questão pouco evidenciada nas pesquisas estudadas que chamou a atenção durante as leituras de jornais de época, foi à intensa veiculação de informes publicitários sobre o empreendimento, sendo que a maioria deles evidenciava a facilidade de acesso ao novo bairro com a construção do viaduto sobre a linha férrea (o primeiro viaduto da cidade, concluído em 1954, o atual Viaduto Jânio Quadros),

\footnotetext{
${ }^{63}$ BONADIO, Op. Cit. p225.

${ }^{64}$ LEITE, WALTER RINALDI. Santa Rosália é o Primeiro Bairro Planejado de Sorocaba. Revista A Cidade: Sorocaba de Todos Nós 351 Anos. Suplemento do Jornal Cruzeiro do Sul. Fundação Ubaldino do Amaral, Ano 1. Sorocaba, 2005, p. 37.
} 
além de frisar que o jardim Santa Rosália possuía escolas, praças, jardins, armazéns, cine-teatro igreja e etc. Como Pereira da Silva gozava de muito prestígio entre os políticos da época, podemos supor que tenha conseguido influenciar a construção deste viaduto, pois sabia da extrema valorização que este feito Ihe traria.

"Embora não tenha disputado qualquer cargo eleitoral Severino Pereira da Silva nunca perdeu as eleições municipais em Taquaritinga do Norte. Em Sorocaba sempre apoiou, com recursos e votos, candidatos locais, mas sua perspectiva era mais ampla. Utilizando os mesmos métodos fazia amizades nos principais centros do poder. Cultivar alianças era a outra face de sua atividade de empresário" ${ }^{65}$.

Por todas estas características que o Jardim Santa Rosália possuía, o novo bairro acabou se tornando um enorme sucesso de vendas e sonho de consumo das classes mais abastadas, uma vez que suas qualidades eram muito acima dos padrões de loteamentos existentes à época em Sorocaba.

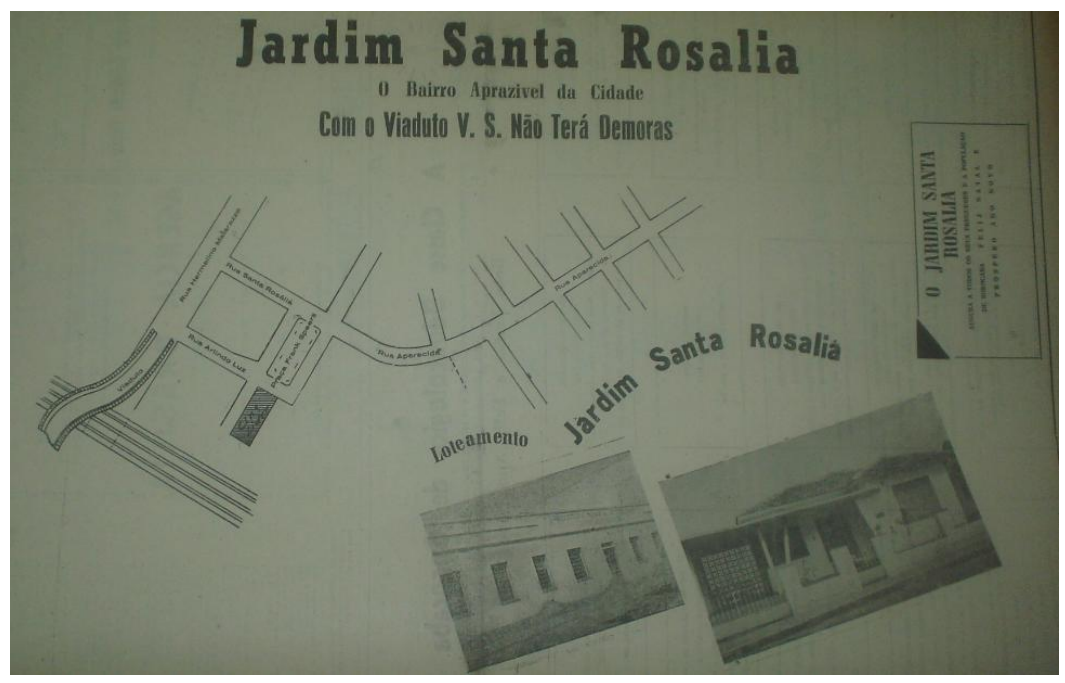

Figura 57: Informe publicitário do empreendimento Jardim Santa Rosália. Fonte: Diário de Sorocaba, 25.12.1959. Acervo de Wesley Carlos da Silva.

\footnotetext{
${ }^{65}$ BOANDIO. Op. Cit. p.225.
} 


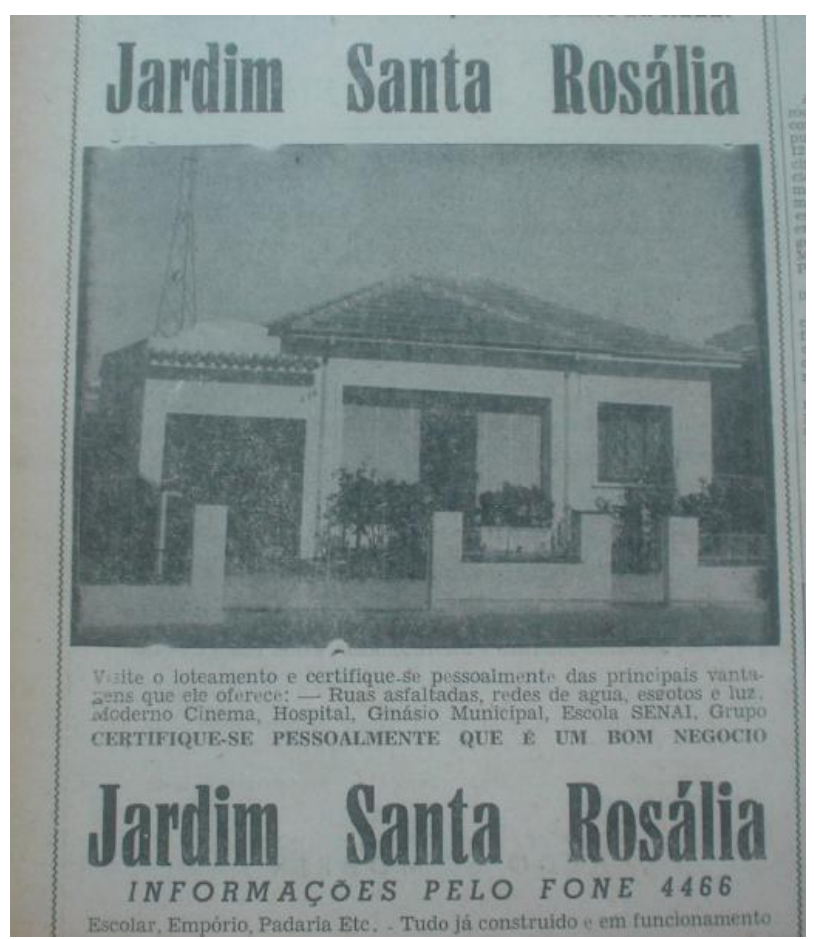

Figura 58: Informe publicitário do empreendimento Jardim Santa Rosália. Fonte: Jornal Cruzeiro do Sul, s/d. Acervo de Wesley Carlos da Silva (imagem 1).

Com o passar dos anos, aquela que era a maior vila operária da cidade, transformou-se num espaço heterogêneo de convivência social, abrigando desde a classe operária (em suas diversas estratificações), bem como pessoas de classe média e classe alta, proporcionando uma convivência intensa de todos os extratos sociais. Durante as pesquisas, não foi encontrado nenhum outro exemplar de bairro operário que tivesse uma configuração parecida com a de Vila de Santa Rosália. 


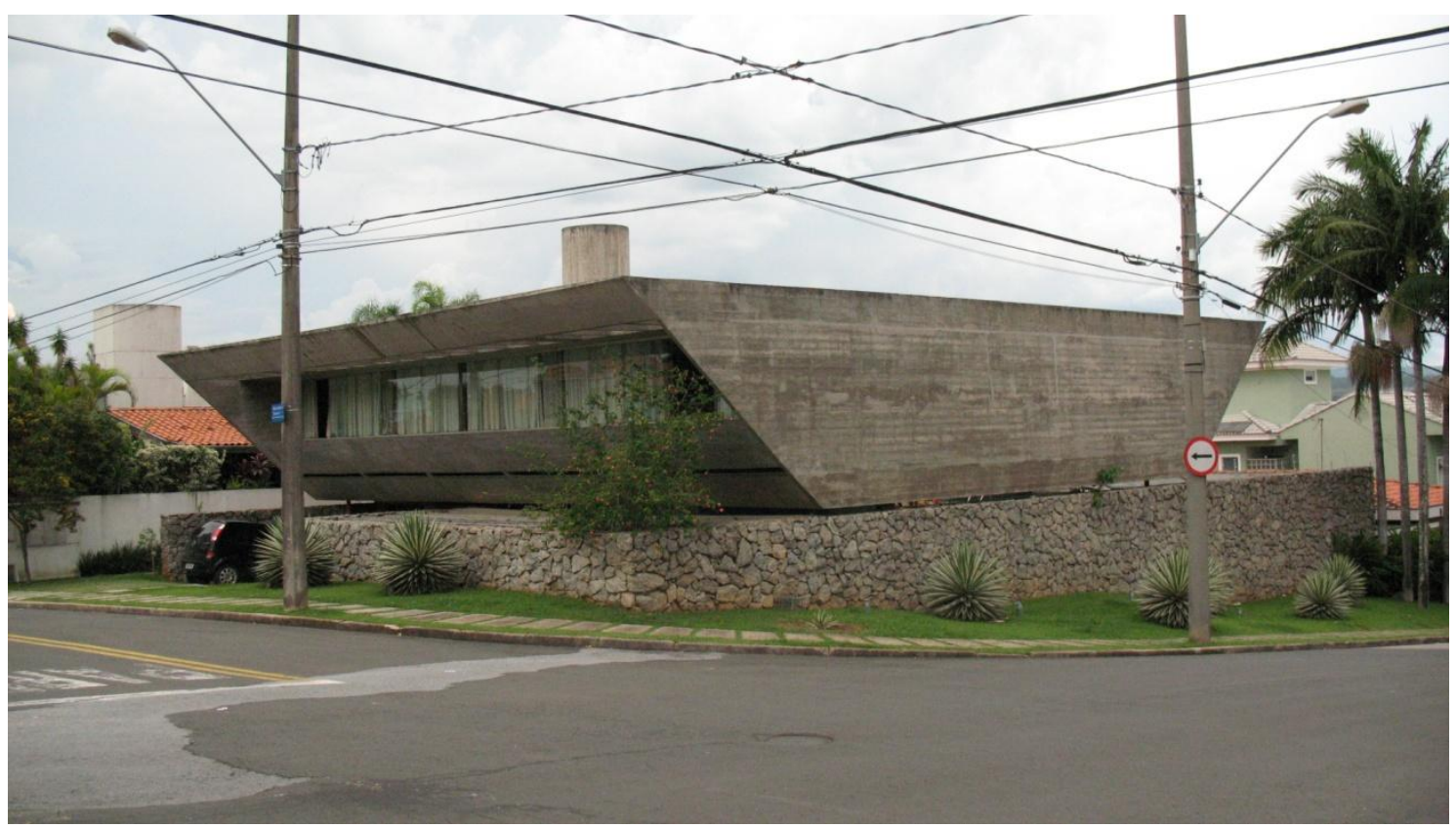

Figura 59: Residência Eduardo Álvaro Vieira, Jardim Santa Rosália - Arquiteto Décio Tozzi $\left(1974{ }^{66}\right)$, 2011. Fonte: do autor.

"No projeto de Severino Pereira da Silva, cada uma das melhorias sociais de suas empresas era um elemento do marketing da CNE junto ao governo. Traduzindo a sintonia com o ideário da paz social, eles lhe abriam portas, permitiam-lhe fazer amizades e descobrir novas fontes de financiamento.

Essa presença marcante em atividades alheias aos seus próprios negócio - a produção e vendas de tecidos - será um dos obstáculos que a empresa enfrentará depois de 64, quando o governo federal, pelos homens que definiam, sua política econômica, passa a ver como um contra-senso que um grupo dotado de tão grande patrimônio possua tão pouca liquidez. Começa a venda das casas e dos terrenos" ${ }^{67}$.

O autor acima, ao falar da venda de casas e terrenos, está se referindo à venda de casas e terrenos da vila operária de Santa Rosália (desde as casas operárias à preços acessíveis aos funcionários, quanto os imóveis desativados - Cine-Teatro, edifício do Grupo Escolar, edifício da Escola Ginasial, edifício da Escola SENAI, e etc.). Também é desta época a doação de terras do grupo empresarial para a tutela e administração da Prefeitura Municipal de Sorocaba, por exemplo, a Praça Pio XII, a Praça da Amizade, o terreno onde foi construído o Estádio Municipal Walter Ribeiro, o terreno onde foi

\footnotetext{
${ }^{66}$ Décio Tozzi. Disponível em: http://www.deciotozzi.com.br/ br/flash/decio-tozzi.htm Acessado em: 7.1.2011.

${ }^{67}$ BOANDIO. Op. Cit. p. 225.
} 
construída a 14a CSM - Circunscrição de Serviço Militar de Sorocaba, o terreno da nova Escola SENAI, terrenos para escolas municipais, e etc.

Assim como no caso dos Kenworthy, acrescentaremos a seguir algumas propriedades da família Pereira da Silva que julgamos necessárias para o entendimento das conseqüências que resultaram para os bairros operários e/ou para a cidade de Sorocaba:

\section{A Chácara do Alto}

A Mansão que pertencia a Fábrica Santa Rosália, onde moraram chefes diretores e também a família Pereira da Silva no início de sua administração, ficava na chamada Chácara do Alto, também conhecida por casa da diretoria. Localizava-se onde hoje é a esquina da Avenida Pereira da Silva coma Rua Afonso Cavalini (aproximadamente 200 metros da fábrica). Dentro do perímetro da chácara, já durante a administração Pereira da Silva, fora construída uma grande caixa d'água subterrânea que futuramente iria servir para abastecer as residências da nova vila operária, assim como do Hospital São Severino, a Creche, as Escolas, a praça e o campo de futebol. Não há imagens ou fotografias referentes á este imóvel.

\section{A Chácara Sônia Maria}

Em 1944, período auge das exportações da companhia, Pereira da Silva compra um grande terreno, afastado do bairro de Santa Rosália, numa região conhecida na época como Terra Vermelha (no caminho para a região do Itavuvu). Lá, Severino planejava construir uma mansão que comportasse toda a sua família com grande conforto. 
"Papai quis fazer uma casa melhor, ele arrumou um arquiteto americano, que projetou uma casa toda avarandada, e com sete quartos já que a família era muito grande. Era muito bonita, tinha uma sala toda de mármore, muito fria, mas bela" ${ }^{68}$.

A imprensa local da época publicou uma nota em 1944 enaltecendo o ineditismo da construção:

“... na antiga chácara João Basílio, ergue-se a mansão 'Sônia Maria'. É naquele foco luminoso, que todas as noites chama a atenção dos sorocabanos, como se lá houvesse festa permanente (...) é lá no alto, dos lados da Terra Vermelha, onde a luminosidade ofuscante simboliza, em silêncio, o fulgor irradiante de um cérebro, de um pensamento, de uma vontade voltada para o progresso!" 69

A família morou na mansão de maneira intermitente. Após o final da Segunda Guerra Mundial, em 1945, os três filhos de Severino vão estudar nos Estados Unidos. Em 1948, Carlos Alberto (o filho mais velho) retorna para trabalhar na Companhia em Sorocaba. Suas irmãs partem para o Rio de Janeiro. Pouco tempo depois, Severino também retorna para o Rio, administrando as empresas pelo escritório de lá.

A chácara só voltaria ser realmente habitada após o casamento de Carlos Alberto, em 1953. Lá nasceram e se criaram seus quatro filhos:

"A chácara era tao grande, que eu até criava uma vaca holandesa, as crianças tomavam leite debaixo da vaca (risos), criava galinha, cachorros, cavalos, foi muito gostosa essa época, eu passeava a cavalo com meus filhos pelo Itavuvu, lá não havia nada, nem avenida nem esses grandes bairros de hoje" 70 .

O imóvel pertenceu à família de Pereira da Silva até 1999. Com a falência da empresa e inúmeras dívidas trabalhistas e tributárias, foram obrigados a vendera Chácara Sônia Maria. Assim como no caso da Fábrica Santa Rosália, o imóvel foi comprado por uma empresa de hipermercados (a francesa Carrefour). Após apuração do Ministério Público ${ }^{71}$ sobre a pertinência do tombamento da chácara, a mansão foi demolida, sendo preservada apenas a massa arbórea que a circundava.

\footnotetext{
${ }^{68}$ Depoimento de Carlos Alberto Moura Pereira da Silva, filho de Severino Pereira da Silva. IN: SILVA, Wesley Carlos da. Op. Cit. p. 57.

69 JORNAL CRUZEIRO DO SUL, 18.06.1944. IN: SILVA, Wesley Carlos da. Op. Cit. p. 58.

${ }^{70}$ Depoimento de Carlos Alberto Moura Pereira da Silva, filho de Severino Pereira da Silva. IN: SILVA, Wesley Carlos da. Op. Cit. p. 59.

${ }^{71}$ JORNAL CRUZEIRO DO SUL, 23.06.1999. Cidades p. A3.
} 


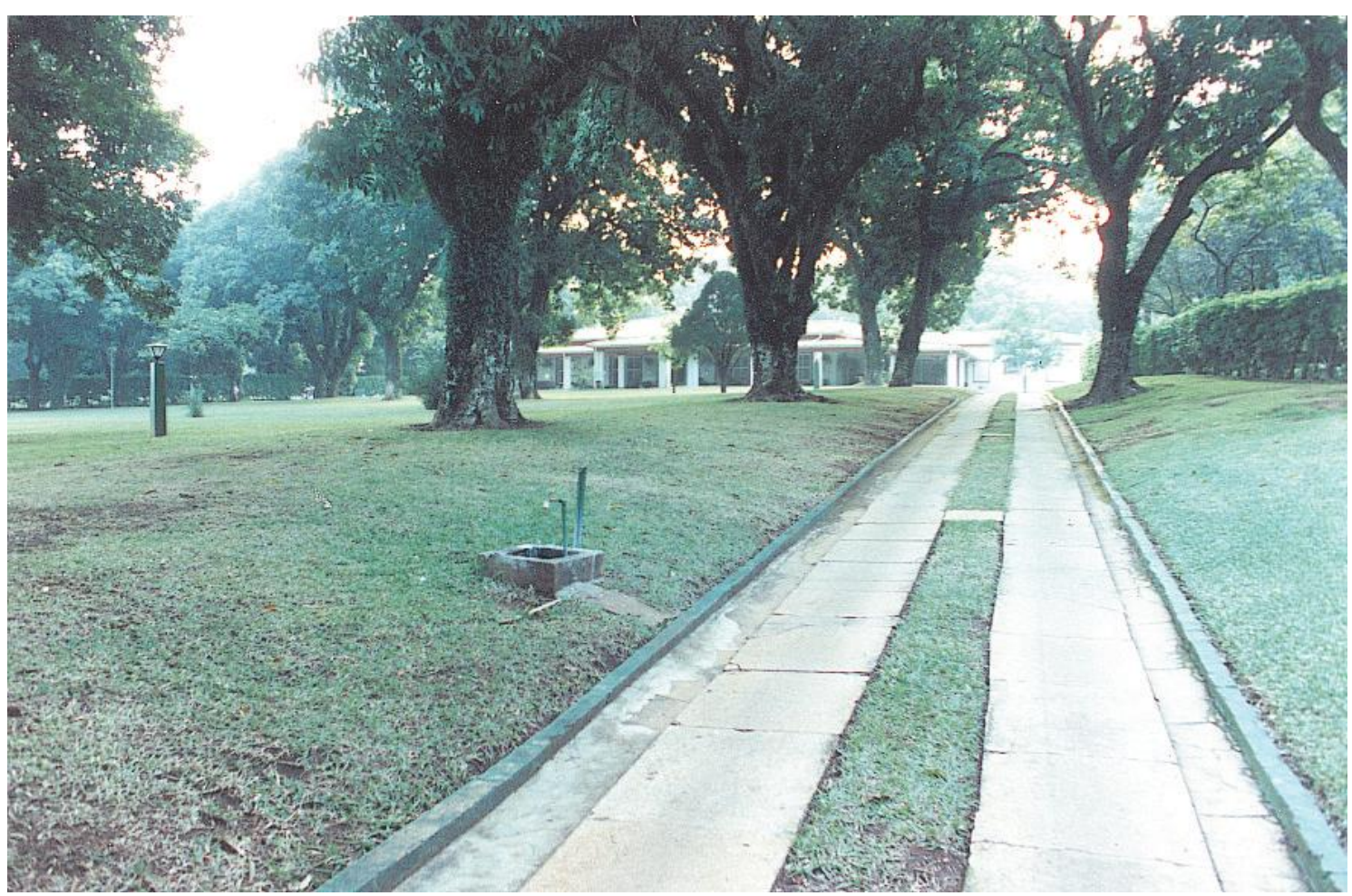

Figura 60: Chácara Sônia Maria - Acesso principal. Fonte: JORNAL CRUZEIRO DO SUL, 17.6.1999.

\section{Outras Propriedades}

Além das residências citadas acima, a família Pereira da Silva foi proprietária, de acordo com a revista comemorativa dos 50 anos da CIANÊ, de uma "fazenda com 3 milhões de pés de eucalipto, situada a 10 quilômetros da cidade de Sorocaba, além de uma usina de algodão no município de Rancharia" ${ }^{72}$.

Após anos e anos de crescimentos e benfeitorias no bairro, a empresa tenta realizar um arrojado plano: começa a comprar inúmeras companhias têxteis do estado a fim de se tornar o maior grupo têxtil do país. O plano inicial era comprar fábricas desatualizadas ou à beira da falência, com o intuito de modernizá-las. A primeira das indústrias compradas pela CNE foi a Fábrica Nossa Senhora da Ponte, que estava sob

${ }^{72}$ CIA. NACIONAL DE ESTAMPARIA - 50 ANIVERSÁRIO, SOROCABA. Magazine das Nações. Ano 12 Edição Especial. Editora e Publicidade Roman Ltda., São Paulo, Maio de 1960. Além dessas propriedades, a família possuía outras unidades têxteis em Ribeirão Preto/SP e Taquaritinga do Norte/PE, além de indústrias produtoras de cimento em outros estados (Rio de Janeiro, Minas Gerais e Goiás), não fazendo parte deste levantamento. 
posse do Grupo Gasparian. É também nessa época que a empresa desativa e demole alguns edifícios subutilizados, constrói um novo edifício administrativo em anexo à fábrica e promove algumas doações de terrenos no bairro para o poder público (citados acima).

Neste período, o Senhor Severino Pereira da Silva veio a falecer, aos 92 anos. O impacto causado pela abertura comercial do governo Collor, cujo valor dos produtos vindos dos países asiáticos se tornou muito mais baratos do que os nacionais, gerando uma queda brusca de vendas - justamente num período de grandes investimentos da empresa na compra de outras. Pouco tempo depois são fechadas as fábricas Nossa Senhora da Ponte, Santo Antônio e Santa Rosália, permanecendo em funcionamento apenas a Estamparia São Paulo (realizando esporádicos serviços terceirizados). É possível imaginarmos o tamanho do impacto deste fato em Sorocaba, uma vez que no início da década de 1990 a empresa contava com um corpo de 11 mil funcionários ${ }^{73}$.

Como síntese desse processo de industrialização pelo qual a cidade de Sorocaba passou, é interessante a colocação de Lucinda Ferreira Prestes:

"O urbanismo da era industrial em Sorocaba foi constituído pela implantação de indústrias de porte na periferia do centro histórico, em torno da virada do século XIX e representado significativamente pelas grandes construções fabris de influência inglesa do XIX, o período expansionista, que definirá um novo perímetro para a cidade. Os novos limites farão a transposição do rio e da ferrovia para o Leste e o Norte, surgindo respectivamente os bairros do Além Ponte e o Além Linha. De forma embrionária, tendo na construção fabril têxtil uma nova centralidade polarizadora e difusora de urbanidade.

A paisagem urbana sofre mudanças radicais: dos vetustos e senhoriais sobrados de taipa de pilão e tropel de mulas, surgem ágoras os frios perfis serrilhados dos sheds, dos grandes galpões de tijolos e da contundente verticalidade de altas chaminés. Foi-se a cidade tropeira...

A nova Sorocaba adquire outra paisagem onde as fábricas e os apitos tomarão conta da cidade, uma cidade agora, operária. Cada indústria funcionará como um foco irradiador de civilidade, atraindo os trabalhadores para as suas proximidades, quando ela mesma não tiver uma vila operária projetada. A cidade é tomada pelo ritmo das

\footnotetext{
${ }^{73}$ FUNDAÇÃO UBALDINO DO AMARAL. Sorocaba 350 Anos. Suplemento do Jornal Cruzeiro do Sul, Sorocaba, 15.8 .2004$, p.40.
} 
fábricas. O cotidiano de seus habitantes girava, então, em torno disso. A vida passa a ser ordenada pelo pulsar de seus horários. Acertam-se os relógios pelos apitos das fábricas. Distingue-se o som de cada uma delas: - Nossa já são 11 horas, é o apito da Santa Maria!... Corra, menina!...

Tal era a vida regrada pelas indústrias" ${ }^{74}$.

74 PRESTES, Lucinda Ferreira. A Vila Tropeira de Nossa Senhora da Ponte de Sorocaba: aspectos socioeconômicos e arquitetura das classes dominantes (1750-1888) / Lucinda Ferreira Prestes. São Paulo: Proeditores, 1999, pp. 164-165. 
PARTE B

OS DIAS DE HOJE: uma análise crítica.

Para entendermos como se encontra hoje o patrimônio industrial têxtil de Sorocaba, cabe verificar algo relativo questões que encaminharam essa condição atual. Verificamos que entre outros fatores há íntima ligação com o processo de estabelecimento de um órgão de preservação de monumentos históricos local.

Durante o início da década de 1980 uma série de fatos estimulou e determinou a futura criação de um Conselho local de preservação. Dentre eles, a morte de Aluísio de Almeida (pseudônimo do Monsenhor Luíz Castanho de Almeida), fundador do Instituto Histórico Geográfico e Genealógico de Sorocaba e tido como o "pai" da historiografia sorocabana. Foi também relevante o movimento de profissionais liberais (arquitetos, historiadores, museólogos, engenheiros entre outros) preocupados com as mudanças que a cidade atravessava principalmente às relacionadas com as demolições de importantes edifícios na região central, por exemplo: a Casa-grande de Baltazar Fernandes, o Convento de Santa Clara, Igreja de Santo Antonio (todos demolidos durante a década de 1960), edifício da Ação Católica e as reformas e /ou demolições de diversos casarões, solares e sobrados durante a própria década de 1980.

Paralelamente a estes fatos, ocorreram levantamentos de Gustavo Neves Rocha Filho, do CONDEPHAAT - Conselho de Defesa do Patrimônio Histórico, Arqueológico, Artístico e Turístico, em diversas cidades do interior do estado, sendo Sorocaba uma dessas cidades pesquisadas. Desse levantamento local, que contava com um detalhado histórico da cidade, foram selecionados alguns imóveis como sendo dignos de estudos pormenorizados para futuros tombamentos.

Incentivada por este estudo, a Secretaria de Planejamento e Habitação da Prefeitura Municipal de Sorocaba se mobilizou em direção a um levantamento local de imóveis de interesse histórico-culturais. Em parceria com o recém-criado CONDEPHISO Conselho de Defesa do Patrimônio Histórico de Sorocaba elaboram o "Inventário dos 
Prédios Históricos da Área Central". De acordo com Cunha, o primeiro órgão relacionado à preservação de bens culturais em Sorocaba

"[...] formou-se através da iniciativa de um pequeno grupo da sociedade civil, arregimentando tanto funcionários públicos (principalmente aqueles ligados às Secretarias de Educação e Cultura e de Edificações e Urbanismo) como profissionais liberais (muitos deles historiadores ligados ao Instituto Histórico, Geográfico e Genealógico de Sorocaba - IHGGS). Este Conselho não era um órgão deliberativo, mas de assessoramento, cujo objetivo era desenvolver ações que estimulassem $e$ facilitassem a preservação do acervo cultural de Sorocaba. No entanto, o CONDEPHISO nunca logrou o apoio político necessário à sua real implantação, sendo extinto no início da década de 1990, tendo como saldo de sua ação alguns tombamentos municipais decretados em caráter provisório e indicações para tombamento estadual de outros bens" ${ }^{1}$.

Este levantamento municipal, ao contrário do estudo elaborado pelo CONDEPHAAT, não era nem um pouco "técnico". Na verdade tratava-se de uma coletânea de fotografias de 123 edifícios localizados no centro da cidade, com poucas tomadas de cada imóvel (uma ou duas), somada a uma brevíssima descrição dos prédios. Cabe salientar que além de breves, estas descrições eram bastante imprecisas e, em alguns casos, equivocadas. Os edifícios selecionados eram por critérios pouco claros, ora pelas características arquitetônicas, ora pela época em que foram construídos, ou, mais raramente pela tipologia dos prédios. Todavia, devido à falta de conhecimentos dos responsáveis pelo levantamento, muitos edifícios selecionados como antigos, eram na verdade edificações da década de 1950/60, enquanto que outros edifícios importantes como as fábricas têxteis (exceto a Fábrica Nossa Senhora da Ponte), os bairros operários ou edifícios fora do centro da cidade não foram incluídos no levantamento.

Muitos desses fatos ocorreram pelo ímpeto do querer preservar a qualquer custo, sem seguir as normatizações devidas, até porque as pessoas envolvidas nesses processos não as conheciam.

Depois da realização deste "estudo", algumas edificações que constavam no levantamento foram sendo tombadas por medida de decreto municipal (por exemplo:

\footnotetext{
${ }^{1}$ CUNHA, Cláudia dos Reis e. O Patrimônio Cultural da Cidade de Sorocaba: Análise de uma Trajetória. Dissertação (Mestrado em Arquitetura e Urbanismo) - Universidade de São Paulo, São Paulo, 2005, pp. 136-137.
} 
Mercado Municipal, as fábricas Nossa Senhora da Ponte e Santo Antonio, Mirante Ondina e Usina Diesel da Fábrica São Paulo).

Estabelecido em 26 de setembro de 1994, através da Lei Municipal $n^{\circ} 4.619$, o CMDP se tornou um órgão oficial, porém, nos mesmos moldes do antigo CONDEPHISO, sendo um Conselho consultivo de assessoramento. Suas atividades foram regulamentadas pelo Decreto $n^{\circ}$ 9.452. Também se institui a Seção de Patrimônio Histórico, Artístico e Cultural de Sorocaba - SPHAC, pasta pertencente à Secretaria de Educação e Cultura que tinha como missão supervisionar os imóveis tombados, auxiliar nas pesquisas e processos de tombamentos, além de vistoriar obras de intervenção nos bens listados.

A partir destes acontecimentos iremos descrever como ocorreram as intervenções em nossos objetos de estudo, assim como os processos de tombamento e apreensão dos mesmos.

\section{Fábrica Nossa Senhora da Ponte e Fábrica Santo Antonio}

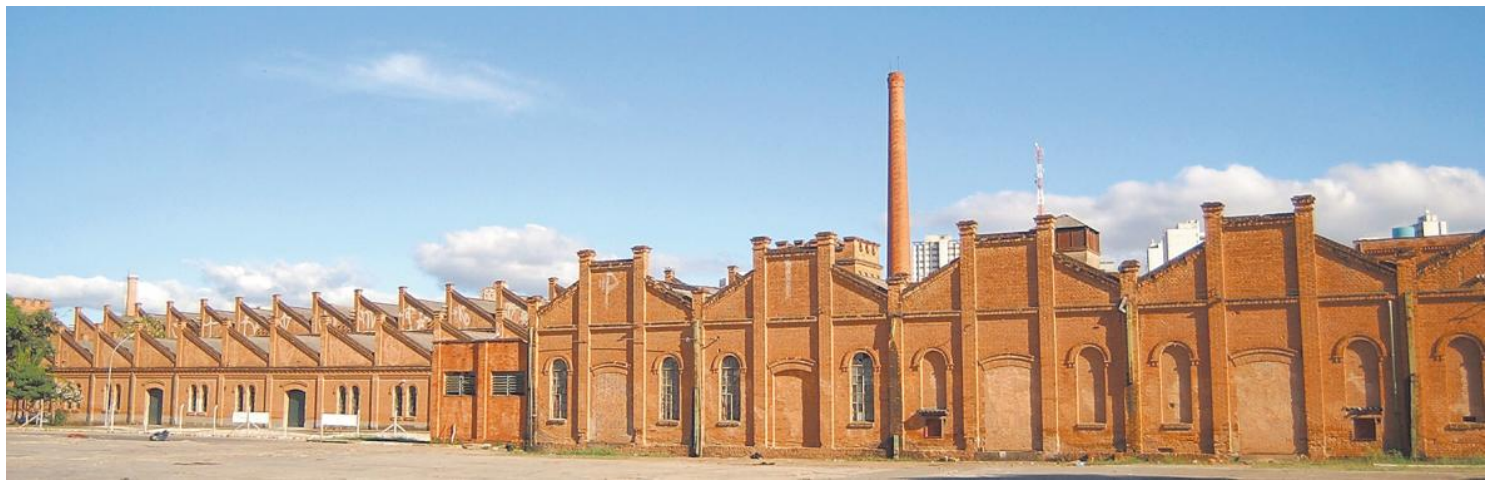

Figura 61: Fábrica Nossa Senhora da Ponte. Fonte: Aldo V. da Silva. Jornal Cruzeiro do Sul, 9.11.2006, p. A-1

Após a desativação de quase todas as indústrias da CNE, no início da década de 1990, as fábricas Nossa Senhora da Ponte e Santo Antonio foram fechadas. Logo após o fechamento, o arquiteto Geraldo Caiuby elaborou um estudo, a pedido da própria 
Companhia, a respeito da importância histórica destas fábricas. Segundo ele, a empresa

“[...] está ciente da responsabilidade que the cabe de preservar tal patrimônio mantendo a sua identidade visual, e o seu papel na vida da cidade. Se outrora representou a força industrial geradora de riquezas e fonte de trabalho para milhares de pessoas, hoje dá continuidade a esse processo, servindo de marco e exemplo para as novas gerações daquilo porque seus pais lutaram e realizaram no passado" ${ }^{2}$.

Contudo, antes mesmo de que qualquer atitude do órgão de preservação local fosse tomada, a Prefeitura anunciou um plano de implantação de terminais de ônibus urbanos. A partir do momento em que a CNE decretou sua falência e acumulava, com isso, inúmeras dívidas com a Prefeitura, o Poder Público viu como oportunidade de renegociação do pagamento das dívidas tributárias das fabricas através de uma permuta de parte dos terrenos dessas duas fábricas para abrigar um dos terminais.

Mesmo após o anúncio da intenção de utilizar esta área para funcionamento de um dos terminais urbanos de transporte coletivo, o órgão de preservação local não se manifestou em prol da necessidade de se realizar um levantamento acurado sobre estes bens antes de qualquer definição projetual do terminal de ônibus, e dos possíveis impactos que ele viria a causar naquela área, não só do ponto de vista preservacionista, mas também urbano.

Não havendo nenhum tipo de impedimento ou obstáculo, o projeto do Terminal Santo Antonio foi desenvolvido totalmente alheio ao fato de estar inserido numa área de grande interesse histórico-cultural. Foram propostas demolições em toda a área do antigo pátio da Fábrica Santo Antonio, que era constituído por edifícios de apoio à produção e também em parte do edifício principal da Fábrica Nossa Senhora da Ponte, para a criação de uma via exclusiva para os ônibus vindos do centro. As obras foram iniciadas em 1991, e o Terminal Santo Antonio foi inaugurado em junho de 1992.

\footnotetext{
${ }^{2}$ Sorocaba (SP): Processo n 9.761/93, p.6.
} 


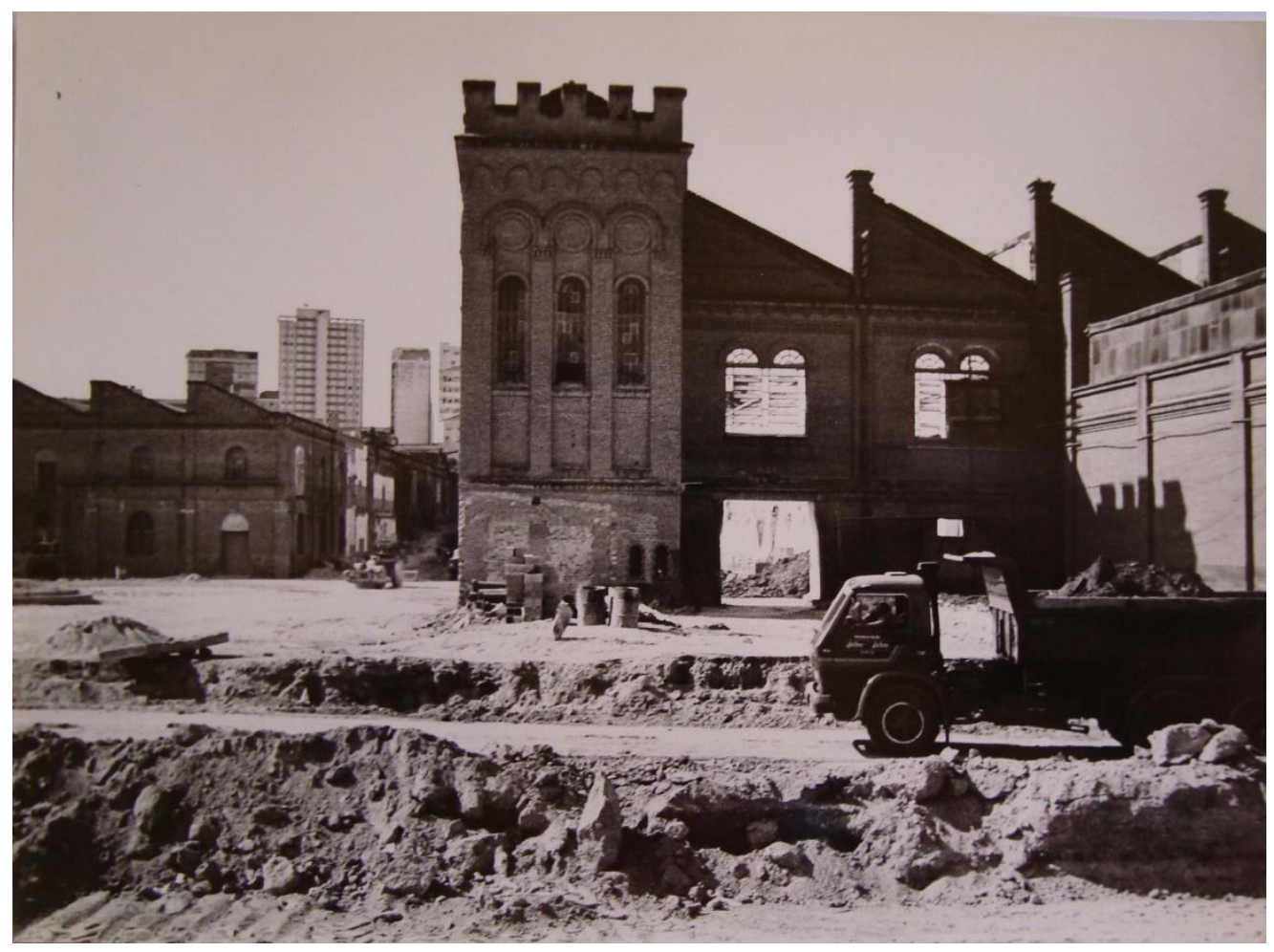

Figura 62: Demolição de parte do edifício principal da Fábrica Nossa Senhora da Ponte (abertura da nova via para acesso de ônibus). Fonte: IHGGS.

Um ano depois, mesmo com todas as demolições e alterações realizadas sem contestações, as Secretarias de Educação e Cultura e Edificações e Urbanismo, iniciaram um levantamento preliminar que viria a se tornar um "laudo circunstancial" propondo o tombamento de alguns dos edifícios do conjunto formado pelas antigas fábricas. Boa parte deste laudo foi embasada no estudo realizado anteriormente pelo arquiteto Geraldo Caiuby. Na realidade esse laudo foi realizado quando muitos edifícios já haviam sido demolidos, dando a triste constatação de legitimar o que já havia sido feito e de remediar o irremediável. Além disso, havia uma necessidade de vender à população a idéia de que o Terminal foi elaborado de uma forma cuidadosa e responsável, o que não era verdade, dentro dessas bases, naquele local escolhido. 


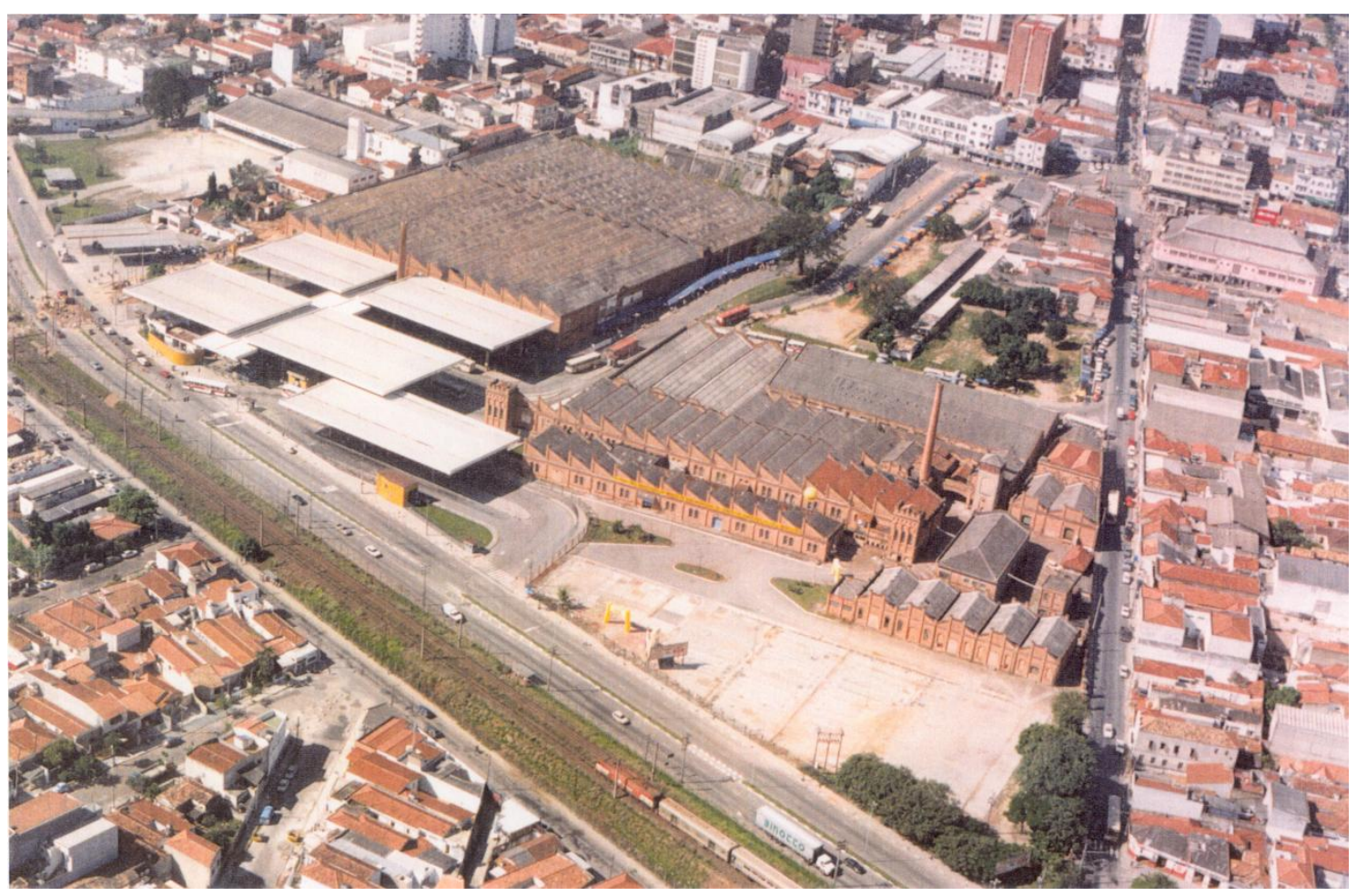

Figura 63: Vista aérea do conjunto arquitetônico das Fábricas Nossa Senhora da Ponte e Santo Antonio. À esquerda, o novo Terminal de ônibus, 1993. Fonte: Museu Histórico Sorocabano

A área envoltória de proteção sugerida aos bens tombados foi a do próprio terreno das fábricas, o que demonstra mais uma vez a intenção de não interferir num status quo existente, ou seja, não houve por parte das autoridades locais a devida coragem para tocar nas feridas e nos interesses ligados à especulação imobiliária.

Curiosamente propõem a demolição de alguns edifícios que pertenciam ao conjunto das fábricas, pois estariam interferindo na visualização dos edifícios principais, considerando tudo o que não fazia parte das construções primitivas como interferências indesejáveis ao visual das fábricas, incluindo muitas evoluções técnicas do processo de fabricação e de soluções para os espaços fabris neste rol de "interferências". Ora, se a questão da visualização dos edifícios era tão importante, como permitiram a construção do Terminal Santo Antonio que, além de demolir inúmeros edifícios do conjunto criou uma barreira visual, impedindo a apreciação das fábricas? 


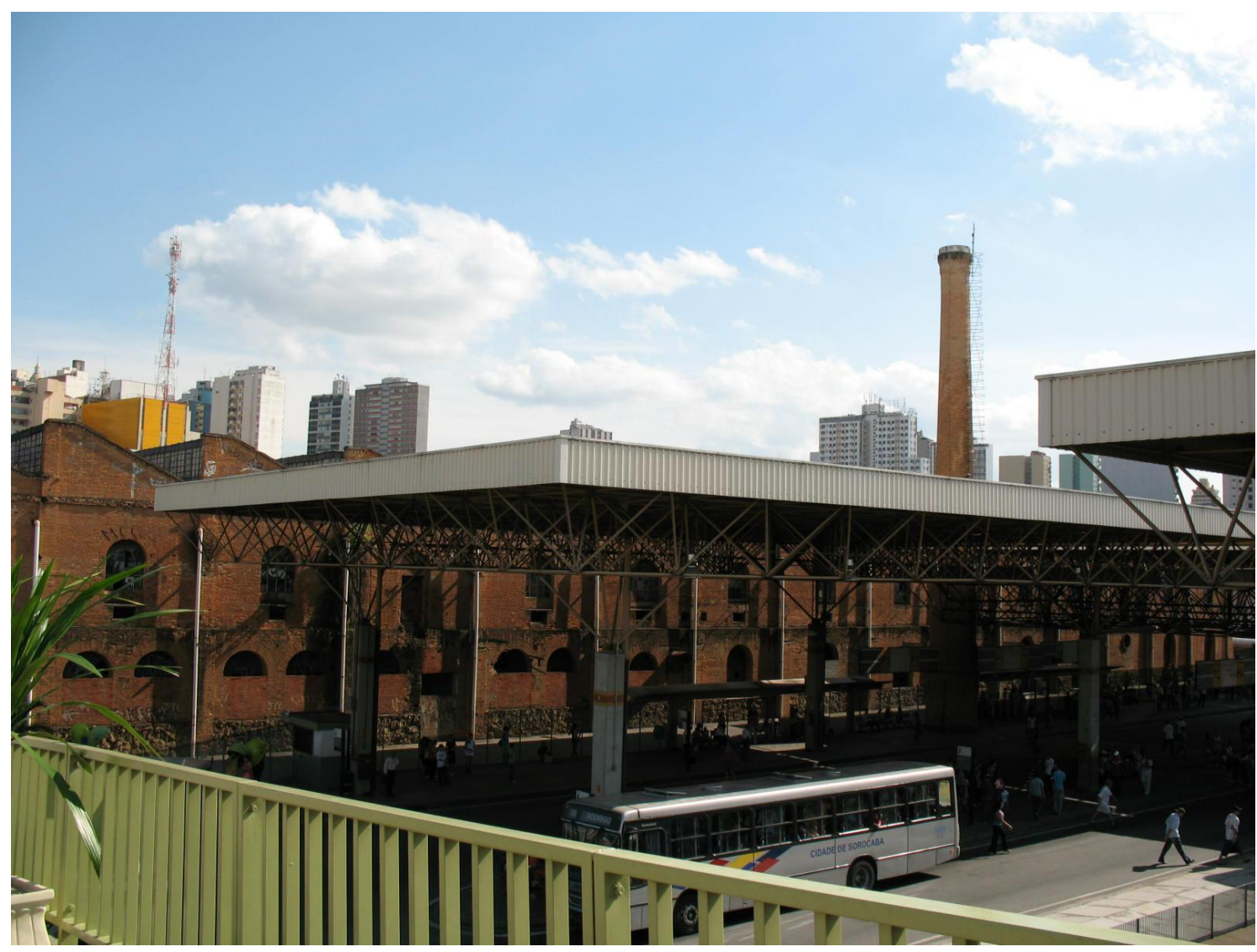

Figura 64: Fábrica Santo Antonio - um cenário para o terminal? Fonte: do autor.

Por fim, foi definido que o grau de tombamento mais adequado para as fábricas seria o GP-2, que estabelece a preservação da volumetria dos imóveis em questão. Porém, o estudo de tombamento não define ou indica nenhum critério de intervenção interna, ou seja, poderá se alterar completamente o interior dos edifícios, desde que não se altere sua volumetria. Com isso, o ambiente interno das fábricas, que é marcado por ser amplo, aberto, banhado por iluminação natural proveniente das aberturas dos sheds e de sua fenestração, poderá ser completamente alterado um dia.

Outra questão que não foi contemplada pelo processo de tombamento refere-se à discussão a respeito da permanência de alguns exemplares dos maquinários, que eram utilizados nas fábricas, durante os anos de funcionamento das mesmas.

Após o tombamento das fábricas, inúmeras tentativas de uso dos edifícios foram feitas. Dentre elas podemos citar: casa noturna (não aprovado pelo CMDP), pavilhão para eventos esporádicos (feiras, festas, shows, jantares beneficentes, circos, e etc.) e 
estacionamento de veículos. Devemos salientar que nenhuma destas modalidades de uso vingou por muito tempo. A tentativa de uso que acabou sendo um pouco mais bem sucedida foi a da Prefeitura Municipal de Sorocaba, que alugou parte do edifício da Fábrica Nossa Senhora da Ponte, adaptando-o de maneira improvisada como Biblioteca Municipal, em 1996. Apesar de a localização ser favorável (centro da cidade, anexo a um terminal de ônibus), com o passar do tempo, e a falta de manutenção do edifício por parte da Prefeitura, inúmeros problemas começam a surgir demonstrando que seriam necessários investimentos significativos para que a biblioteca funcionasse de maneira satisfatória naquele local ${ }^{3}$.

Desse modo a Prefeitura decide construir um prédio próprio para abrigar sua biblioteca, sendo este inaugurado em 2004.

Não achando um uso adequado aos prédios das antigas fábricas, a situação foi ficando cada vez mais insustentável para a CNE, uma vez que as dívidas para com os inúmeros processos trabalhistas que a empresa respondia aumentavam cada vez mais. $\mathrm{O}$ único caminho encontrado entre a justiça e a CNE para solucionar esse problema foi leiloar os edifícios das Fábricas Nossa Senhora da Ponte e Santo Antonio. A empresa sorocabana Splice Desenvolvimento Urbano arremata a compra do conjunto arquitetônico, anunciando pouco tempo depois a intenção de transformá-las em um grande centro de compras.

Para o desenvolvimento do projeto de adaptação dos edifícios em shopping center o Grupo Splice contratou a SHAPHYR Shopping Centers, uma empresa especializada em planejamento e administração de empresas deste segmento, juntamente com um escritório de arquitetura canadense (Design Corp, com filial em São Paulo) para o desenvolvimento do projeto arquitetônico. Para o restauro das fachadas foi chamada o Atelier Sarasá (por indicação do próprio CMDP). Apesar de minhas várias tentativas, pouco conseguimos apurar detalhadamente o projeto do empreendimento diretamente junto a essas empresas, devido ao sigilo exigido pela Splice para com o

\footnotetext{
${ }^{3}$ Conforme depoimento de antigos funcionários.
} 
projeto. Mas ironicamente, recentemente a própria SHAPHYR Shopping Centers divulgou em seu sítio boa parte das informações acerca do empreendimento:

"Com uma localização privilegiada em uma importante avenida da cidade de Sorocaba, acesso facilitado e ótima visibilidade, o Shopping Pátio Cianê será um marco no processo de revitalização do centro da cidade não só pelo seu projeto arquitetônico, que irá retrofitar (Sic) a antiga Fábrica de Tecelagem Cianê, como também pela valorização do Patrimônio Histórico e Cultural do centro da cidade.

Junto ao Terminal de Transporte Urbano Santo Antônio, o terreno de mais de 47,8 mil $\mathrm{m}^{2}$ irá abrigar um shopping de mais de $29 \mathrm{mil} \mathrm{m}^{2}$ de $A B L, 140$ lojas satélites e 11 âncoras e megalojas. Seu belíssimo projeto arquitetônico prevê uma área lifestyle (Sic) para operações de bares e restaurantes, área cultural e centro médico, localizado em um terceiro piso.

Ficha Técnica:

ABL (Área Bruta Locável): $29.000 \mathrm{~m}^{2}$.

Área do terreno: $47.800 \mathrm{~m}^{2}$.

Entretenimento: 8 salas de cinema Multiplex e lazer indoor familiar.

Pisos: 2

Estacionamento: 1.360 vagas" $^{4}$.

\footnotetext{
${ }^{4}$ SHAPHYR Shopping Centers. Disponível em: < http://www.saphyr.com.br/destaque2.php >. Acessado em 30.01.2011.
} 


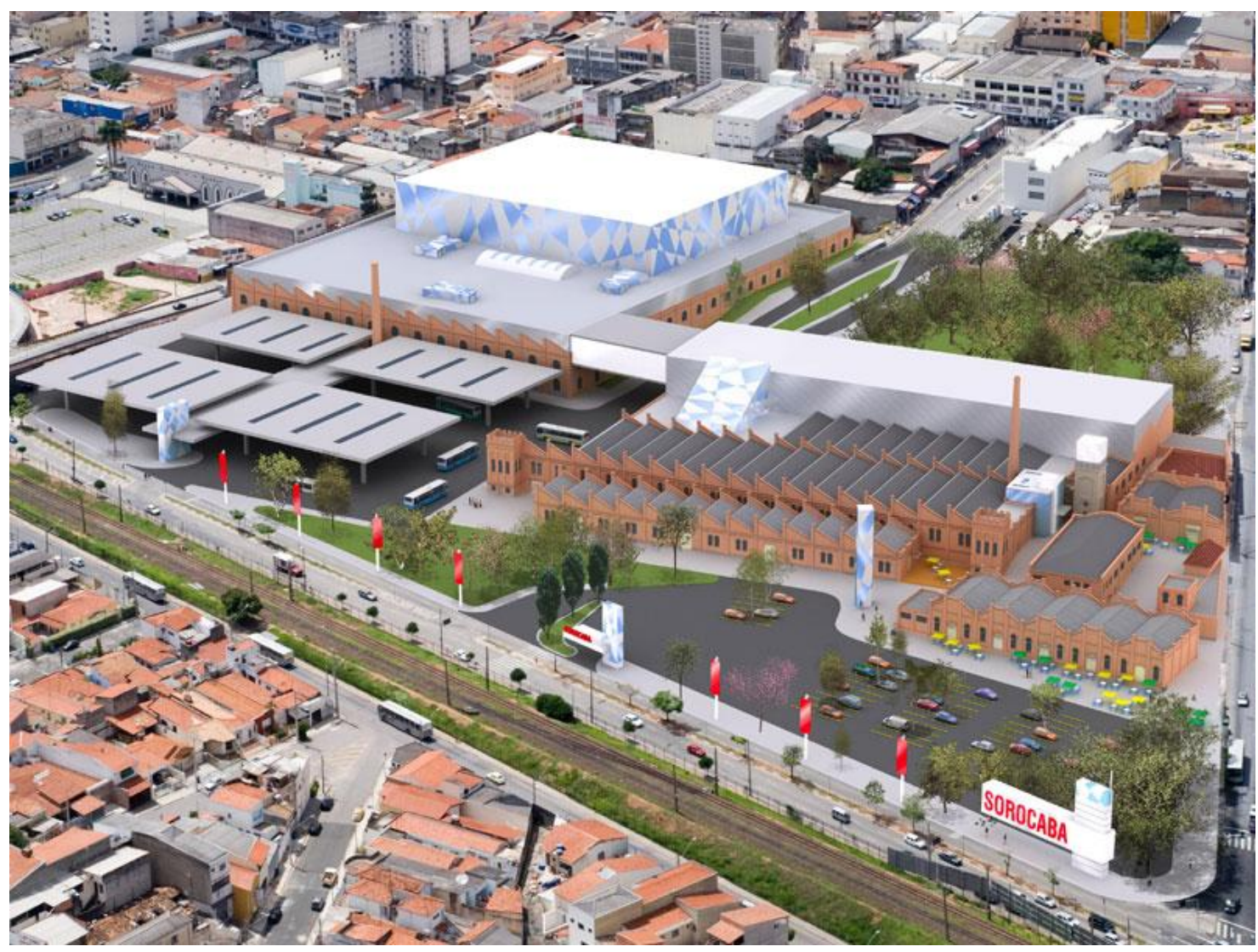

Figura 65: Perspectiva artística do Shopping Pátio Cianê. Vista Aérea do empreendimento. Fonte: SHAPHYR Shopping Centers. Disponível em: < http://www.saphyr.com.br/destaque2.php >. Acessado em 30.01.2011.

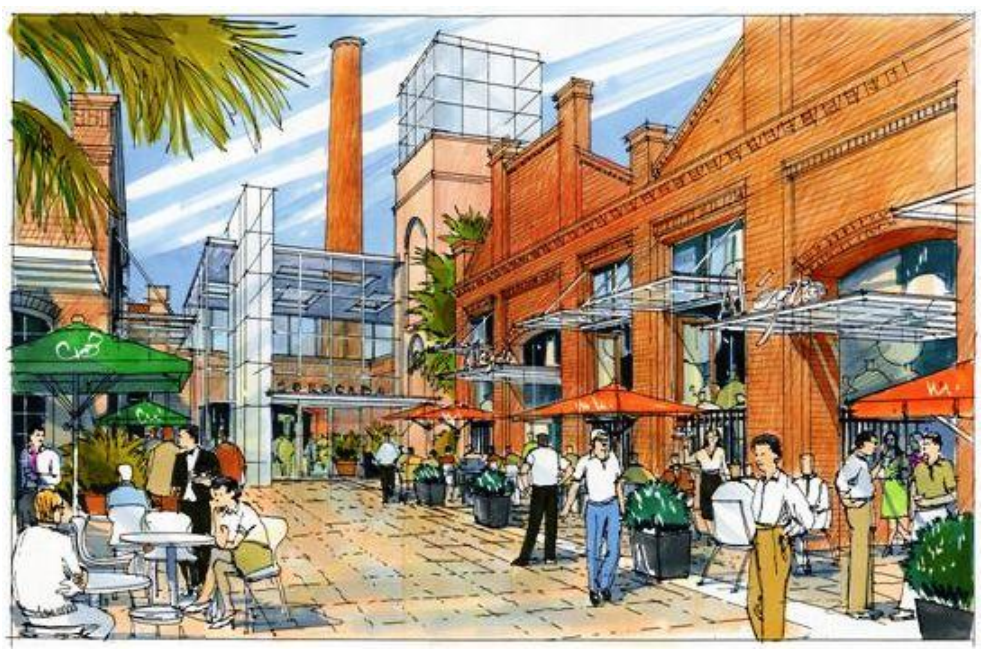

Figura 66: Perspectivas artísticas do Shopping Pátio Cianê. Área Lifestyle. Fonte: SHAPHYR Shopping Centers. Disponivel em: < http://www.saphyr.com.br/destaque2.php >. Acessado em 30.01.2011. 


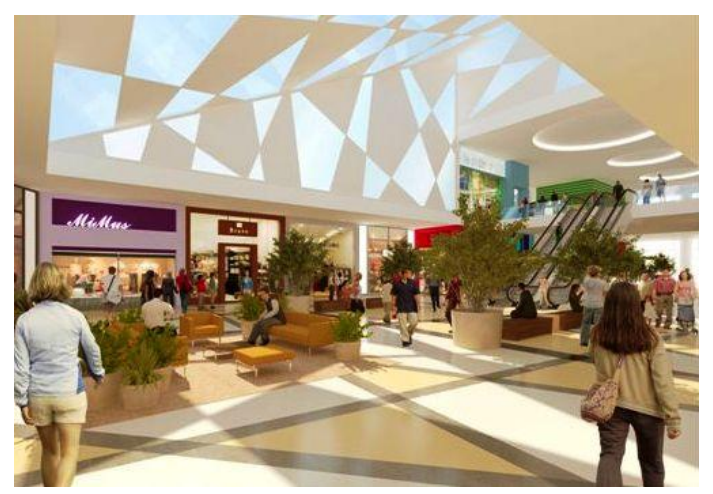

Figura 67: Perspectivas artísticas do Shopping Pátio Cianê. Corredores internos. Fonte: SHAPHYR Shopping Centers. Disponível em: < http://www.saphyr.com.br/destaque2.php >. Acessado em 30.01.2011.

\section{Fábrica Santa Maria}

Desvinculada da CNE após a venda para Pereira da Silva, a Fábrica Santa Maria foi a primeira das fábricas têxteis a fechar as portas, ainda na década de 80 (1982). Seu conjunto arquitetônico estava em perfeito estado de conservação, apresentando como alteração apenas a inserção de um edifício anexo ao portão de entrada onde funcionava a loja da fábrica.

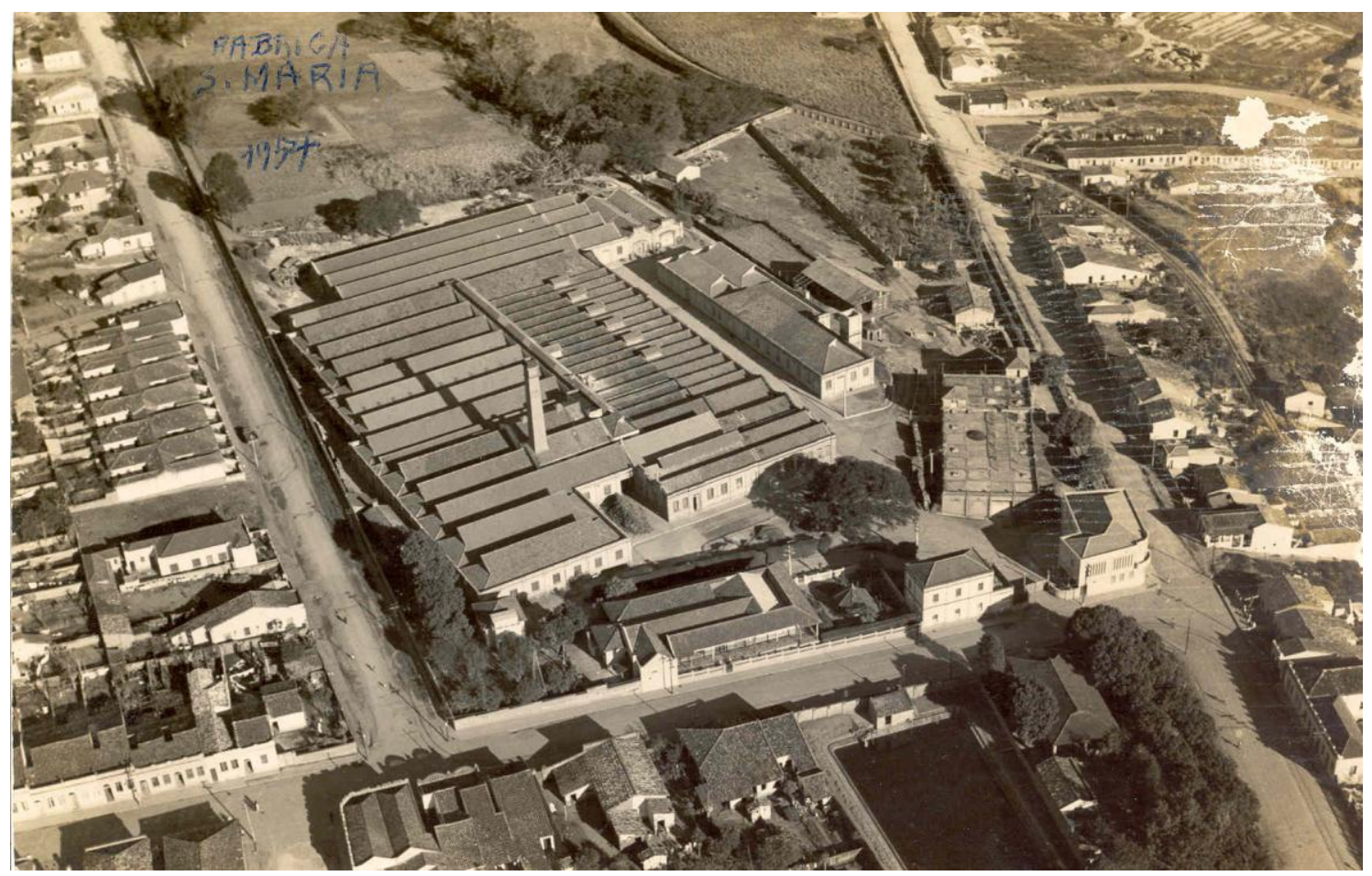

Figura 68: Fábrica Santa Maria, vista aérea. 1954 (?). Fonte: Museu Histórico Sorocabano 
O CONDEPHISO no início dos anos 1990 realizou abertura para estudo de tombamento da fábrica. O levantamento de dados acerca da fábrica estava ainda em andamento, e, portanto incompleto, quando um fato delicado transcorreu, conforme relato da Arq. Solange Soriano ${ }^{5}$, na época funcionária da Secretaria de Edificações e Urbanismo: durante uma tarde de seu expediente diz que foi procurada por um senhor que solicitava informações, a respeito de normas para implantação de loteamento em uma área particular. Ao apresentar o projeto à arquiteta, imediatamente ela reconheceu que se tratasse da área da Fábrica Santa Maria e o alertou do fato de que a mesma estava passando por estudo de tombamento, e análise da sua importância histórica, sendo portanto inviável, para tal loteamento, naquele momento. Imediatamente após a explicação, o proprietário inicia uma discussão argumentando o prejuízo que ele teria com o tombamento de parte de seu imóvel, justificando que apesar de o seu terreno ser grande (38.600 metros quadrados), boa parcela do mesmo estava ocupado por um bosque, portanto "sobrava" apenas a área onde estavam "aqueles prédios velhos" para a realização de seu empreendimento imobiliário. Em nenhum momento houve argumentações acerca da importância cultural ou não do local. Pouco tempo depois do ocorrido, a Prefeitura recebe uma denúncia anônima de que durante a madrugada, inúmeras máquinas começaram a demolir a Fábrica Santa Maria.

De pronto os funcionários públicos acionaram a polícia militar, que interrompeu a destruição dos edifícios por falta de alvará de demolição. Fiscais da Prefeitura embargaram as obras, todavia, praticamente toda a fábrica já estava no chão. Restaram apenas dois pavilhões, o edifício da loja da fábrica, juntamente com uma das chaminés. Com isso, a Prefeitura aciona o Ministério Público local para averiguar e tomar as devidas providências sobre o caso. Após laudo elaborado pelo Professor Nestor Goulart Reis Filho, o Ministério Público acata o parecer da perícia e atesta a importância histórico-cultural do local.

\footnotetext{
${ }^{5}$ Entrevista realizada em Julho de 2009.
} 


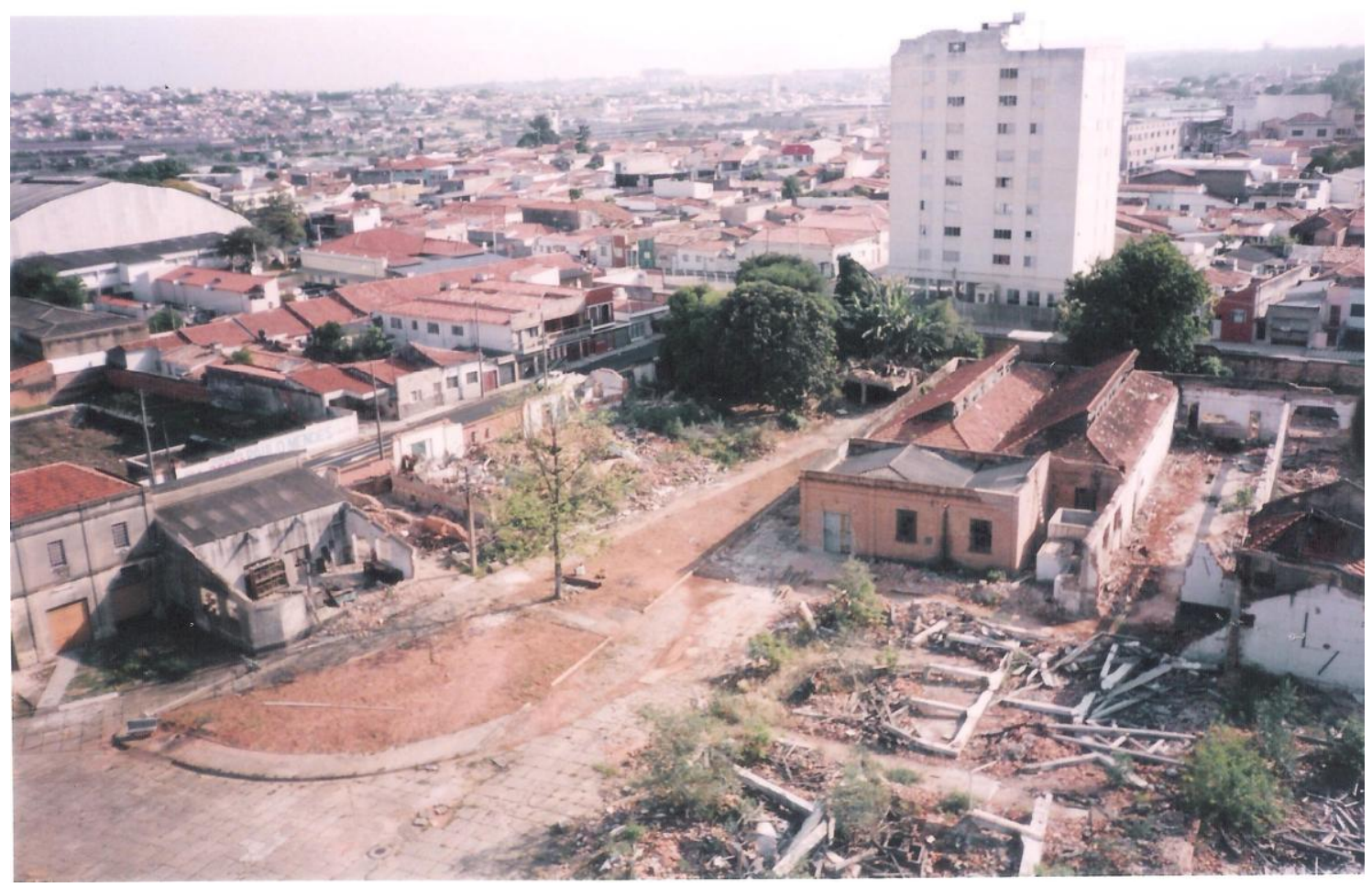

Figura 69: Fábrica Santa Maria recém demolida, 1993. Fonte: Acervo Solange Soriano.

Durante sete anos (1994-2000) o local permaneceu embargado e aguardando acordo entre o Ministério Público, Prefeitura e o proprietário.

Através de um acordo entre as partes, a penalidade imposta foi a de preservar o restante das construções: uma das chaminés, casa das caldeiras e a cabine onde era feito o descaroçamento do algodão; juntamente com a construção de um local para abrigar uma pequena parte do maquinário antigo que foi preservado (também acordado que futuramente seria transformado em um museu da indústria têxtil sorocabana); não foram estabelecidas multas, perda do direito de construir ou penalidades de outra natureza;

O abrigo em questão, juntamente com os trabalhos de restauração foram desenvolvidos pelo arquiteto Wilson Roberto Sales da empresa Sales \& Sales. Esta nova edificação foi elaborada em total semelhança com as edificações restantes, sendo bastante difícil para o público comum a distinção entre o antigo e o novo. Tratase de um pavilhão composto de uma série de pilares de concreto revestidos com 
tijolos de demolição da fábrica, que sustentam a estrutura da cobertura em shed, formada por tesouras, caibros e ripas de madeira, cobertas por telhas francesas, seguindo o mesmo padrão da edificação primitiva. Também podemos observar no local a antiga placa da companhia e o maquinário que será exposto. O fechamento do shed, que seria composto de esquadrias de ferro com fechamento de vidro não foi colocado. Em seu lugar foi improvisado um fechamento de telhas de policarbonato.

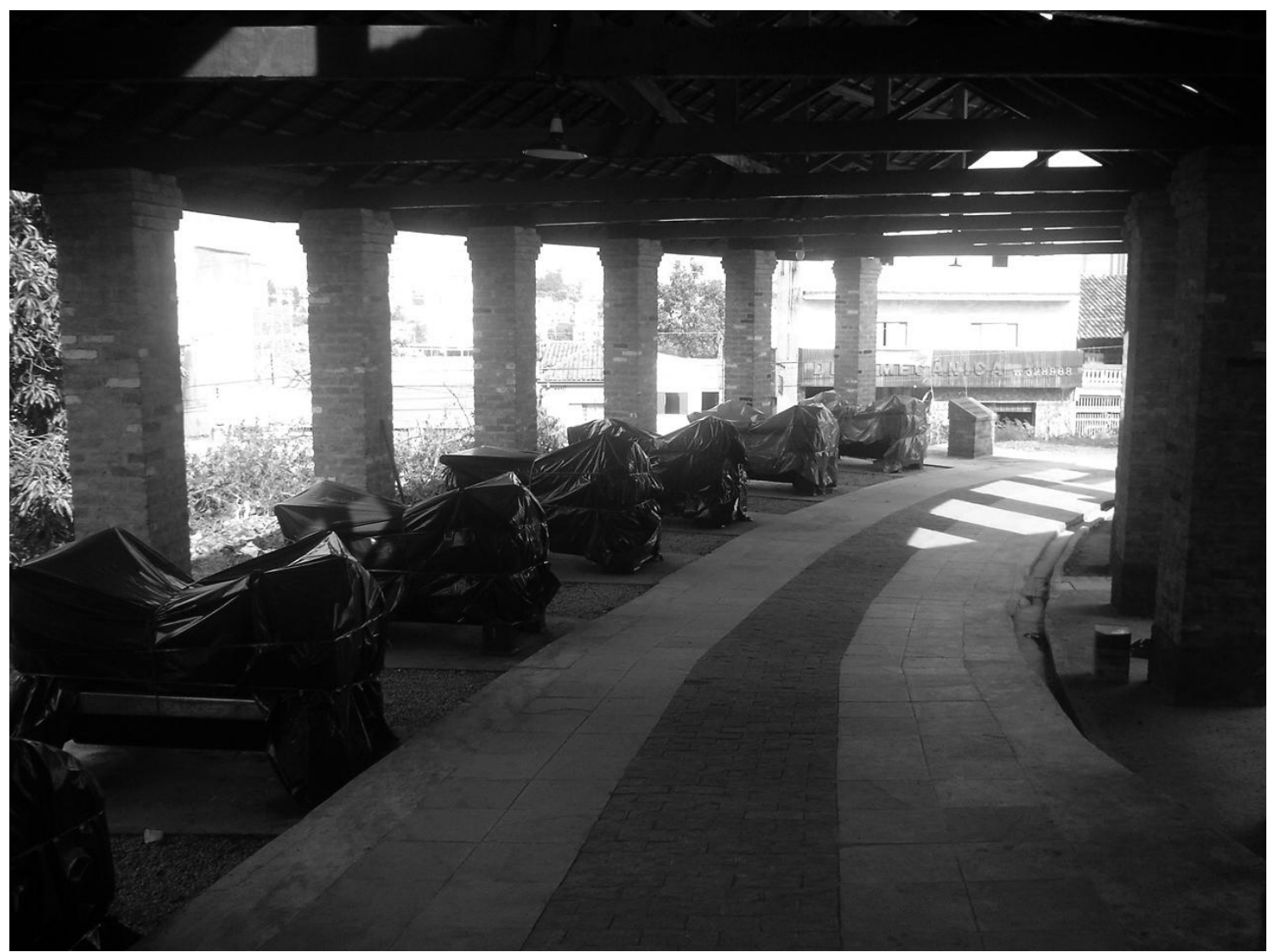

Figura 70: Fábrica Santa Maria - futuro Museu da Tecelagem. 2007. Fonte: acervo Wesley C. Silva.

Ao finalizar as obras a Wimor Empreendimento e Participações Ltda., proprietária do imóvel, recebeu a liberação do poder público pra utilizar os $38.000 \mathrm{~m}^{2}$ de área livre restantes. Após a liberação a empresa voltou a fechar o local, aguardando definição do empreendimento que seria viabilizado. Com isso, o local que seria o museu da indústria têxtil também foi fechado.

Foram necessários mais sete anos para o lançamento do empreendimento. Em março de 2008, a Wimor, juntamente a Agra Incorporadora e a BKO Construtora e 
Incorporadora, é apresentado ao público o projeto Pateo Santa Maria, um condomínio residencial composto de "seis edifícios de apartamentos, com 26 andares cada, totalizando quase 150 mil metros quadrados de área construída. São apartamento amplos, com 3 ou 4 dormitórios, sendo 1 ou 2 suítes e, ainda, opções de projetos com 2 ou 3 suítes, dependendo da metragem dos apartamentos, que podem ser de 107, 134 e 158 metros quadrados de área privativa. Além disso, o novo condomínio irá oferecer o conceito de resort, com moderna e completa estrutura de lazer e segurança, com quadras, piscinas, churrasqueira, playground, sauna, fitness, salão de jogos, cinema, salão de festas/ espaço gourmet, espaço mulher, entre outros, em um amplo ambiente natural, com bosque, trilha para caminhada, árvores nativas, tudo isso monitorado por moderno sistema de segurança" ${ }^{6}$.

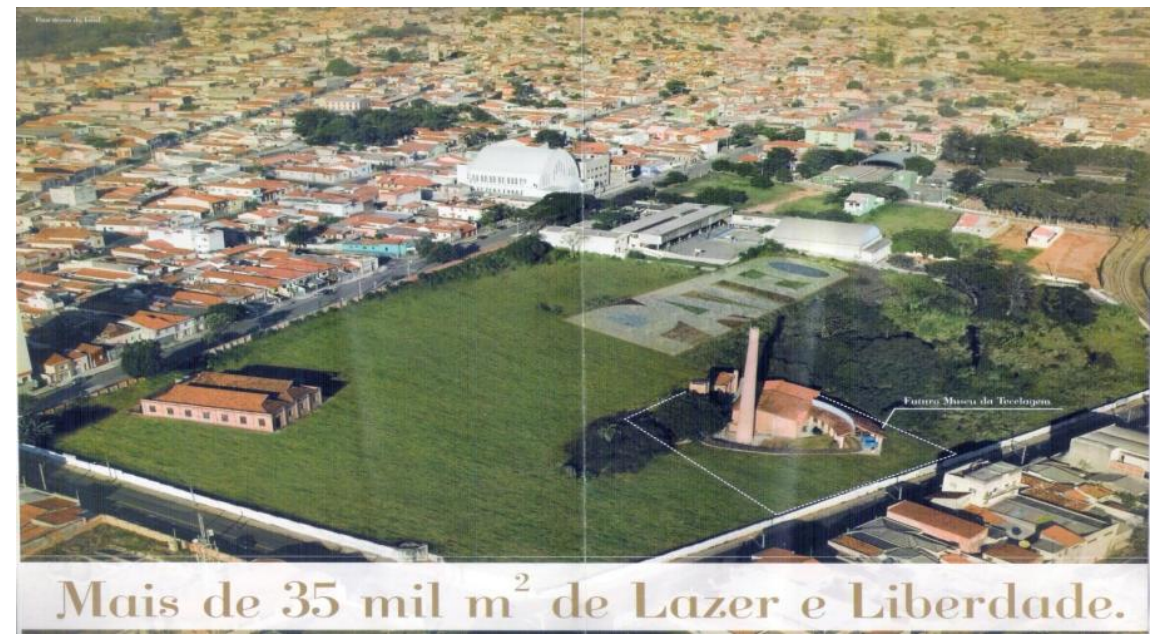

Figura 71: Informe publicitário - lançamento do condomínio Pateo Santa Maria. 2009. Fonte: BKO.

Após o lançamento do empreendimento, muitos eventos foram realizados num dos edifícios que restaram da fábrica, principalmente no intuito de dar uma aparência de uso cultural do mesmo, por exemplo: lançamento de livros, eventos beneficentes, desfiles de moda, e também eventos relacionados ao próprio empreendimento que estava sendo lançado.

\footnotetext{
${ }^{6}$ JORNAL CRUZEIRO DO SUL, 20 de janeiro de 2008, p. C-1.
} 
Em 10 de junho de 2009, pouco mais de um ano após o lançamento do projeto, os incorporadores suspenderam o empreendimento por falta de adesão. Como toda a construção do condomínio estava vinculada com o financiamento de bancos, onde uma das exigências era a venda de $60 \%$ das unidades, e somente foram negociados 100 apartamentos de 624, o financiamento não foi concretizado. Nem os edifícios, nem o museu da tecelagem foram finalizados; as pessoas que adquiriram os apartamentos foram restituídas.

Os empreendedores afirmam que estão analisando a possibilidade de lançar outro projeto para o local, porém para outro público.

A pequena vila operária não fez parte do tombamento. Atualmente as residências pertencem a ex-funcionários, estando parcialmente descaracterizada.

\section{Fábrica São Paulo}

A Fábrica São Paulo, que continua em funcionamento, foi muito alterada pelas diversas adaptações que se tornaram necessárias frente às mudanças tecnológicas muito grandes no processo de manufatura do tingimento, lavagem e estampagem dos tecidos $^{7}$.

\footnotetext{
${ }^{7}$ Conforme depoimento de Carlos Alberto Moura Pereira da Silva, entrevistado em Maio de 2007.
} 


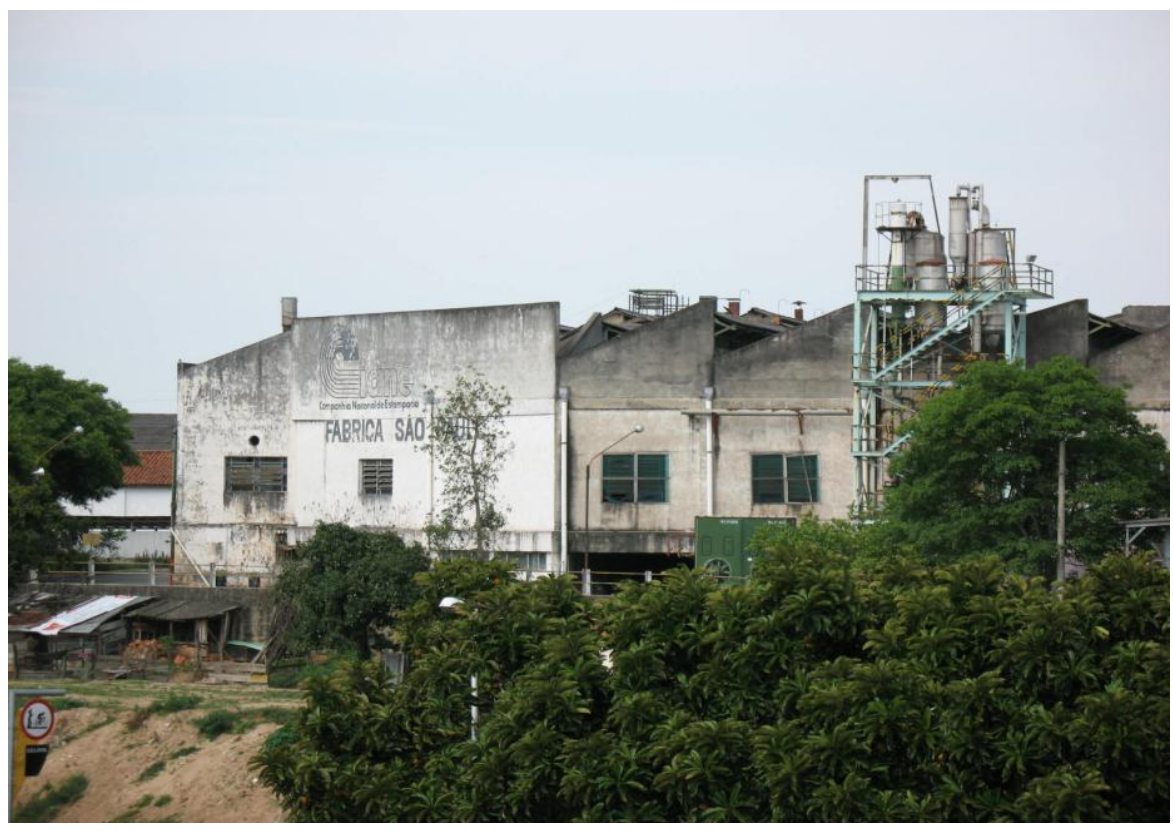

Figura 72: Alvejaria, Tinturaria e Estamparia São Paulo. Fonte: do autor

Administrada por Carlos Alberto M. Pereira da Silva até a sua morte em 15 de abril 2010, a Companhia, que chegou a contar com 11 mil funcionários, hoje possui apenas 370.

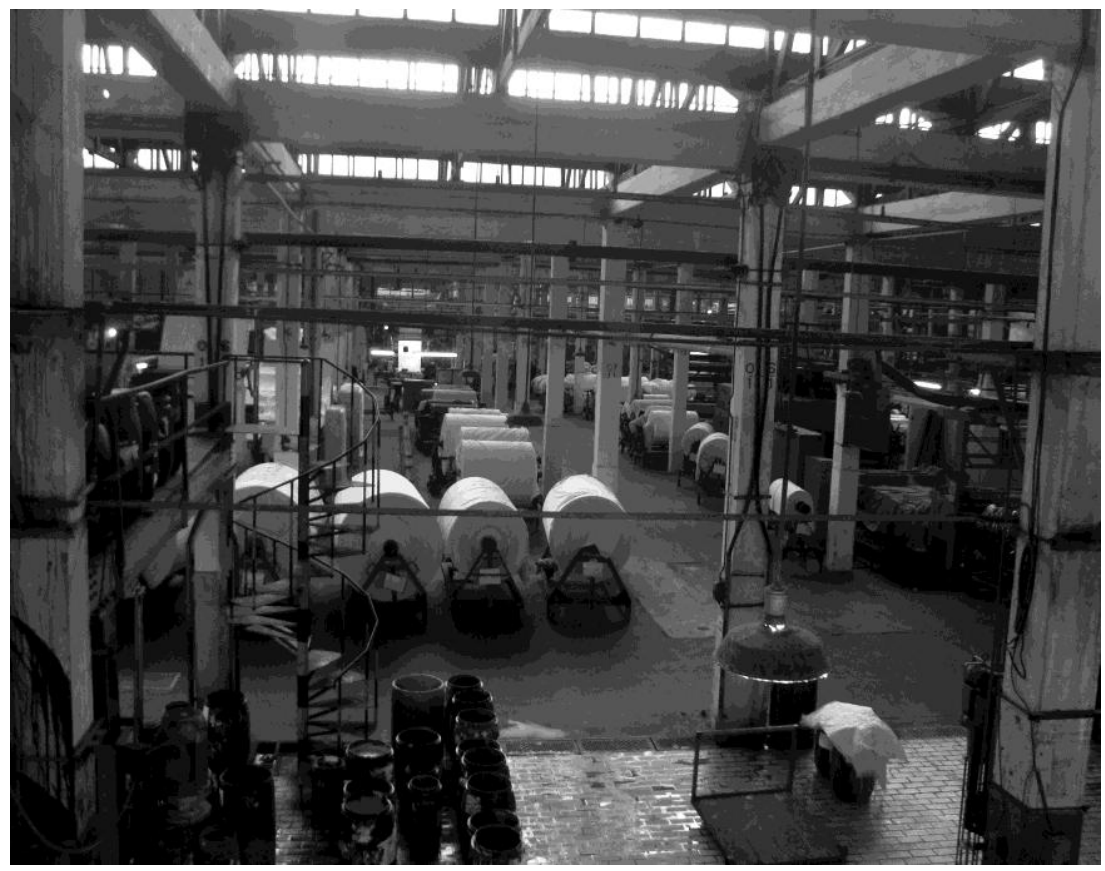

Figura 73: Fábrica São Paulo, vista interna da estamparia. Fonte: acervo Wesley C. Silva

Atualmente, funciona como faccionista, realizando pequenos serviços para outras empresas. Por possuir inúmeras dívidas com instituições bancárias, a Companhia 
Nacional de Estamparia perdeu a posse dos edifícios, sendo eles vendidos por processo de licitação realizado pelos próprios bancos. A Fábrica foi comprada pelo Grupo Splice que teria garantido que os setores de estamparia e de acabamento de tecidos poderiam permanecer no local durante até dois anos, até que a fábrica fosse transferida para outro prédio ${ }^{8}$.

Com a morte de Carlos Alberto Moura Pereira da Silva, este processo de fechamento da fábrica tende a se intensificar. O Grupo Splice não divulgou ainda quais são as intenções com a área e com os edifícios industriais.

Apesar de o conjunto de edifícios da Fábrica São Paulo apresentar pouquíssimas características arquitetônicas originais, sua preservação se torna necessária para o entendimento do processo de industrialização da cidade e urbanização de toda aquela região (o Além-Ponte).

\section{A Usina Diesel}

Foi o único edifício do conjunto de prédios da Fábrica São Paulo que não foi alterado. Era utilizado como depósito de matéria prima. Sua preservação foi motivada pelo grande risco de ruir, em 1994, devido a uma grande erosão e deslizamento próximos ao edifício (causados por sucessivas enchentes), além do medo que ocorresse o mesmo que havia acontecido recentemente com a Fábrica Santa Maria.

Neste mesmo ano, é elaborado um pequeno relatório pela Arquiteta Solange Soriano (funcionária da Secretaria de Edificações e Urbanismo) e pelo Museólogo Adolfo Frioli (diretor do Museu Histórico Sorocabano), expondo a importância e a necessidade de preservar o edifício em questão, juntamente com um breve inventário, contendo levantamento métrico (uma planta) e fotográfico e pequeno histórico da edificação. Assim como no caso das fábricas Nossa Senhora da Ponte e Santo Antonio, o parecer

\footnotetext{
${ }^{8}$ MENDES ORTEGA. Disponível em:

<http://www.mendesortega.com.br/site/pgNoticiaSiteDet.asp?nsu_noticia=125>. Acessado em 10.01.2011.
} 
não consegue tecer argumentos claros sobre a preservação e acaba sugerindo modos de se intervir, que deveriam fazer parte de um projeto de intervenção, e não de um relatório, como por exemplo: remoção de adições, tratamento de superfícies, substituições, reintegrações e etc. Por fim, o documento reforça a necessidade de salvaguarda do edifício (tombamento) como "um primeiro passo" 9 para a sua recuperação, também expondo a necessidade de um uso adequado e contínuo para o bem. Fato curioso é o raio envoltório proposto: por tratar-se de uma área isolada da fábrica e distante de outros imóveis, propuseram um limite de 60 metros, enquanto que no caso das fábricas Nossa Senhora da Ponte e Santo Antonio, implantadas na região central, a área envoltória proposta foi o próprio perímetro delas.

O relatório é apresentado à prefeitura e o edifício é tombado por decreto municipal ( $n^{\circ} 8909$ de 29.04.1994).

Após o tombamento, as áreas ao redor do prédio afetadas pelas enchentes foram recuperadas e o edifício passou por uma manutenção parcial custeada por algumas empresas e pela Companhia de Teatro Anunciação, que passou a utilizar o edifício para apresentações de peças de teatro durante um curto espaço de tempo ${ }^{10}$.

Contudo, as apresentações do Teatro Anunciação terminaram e nenhum outro uso em definitivo foi estabelecido, apenas usos esporádicos. Conseqüentemente, a obra passou novamente por um novo período de abandono.

Além do abandono, o bem ficou sem receber nenhum tipo de manutenção ou conservação, o que resultou novamente no surgimento de problemas como infiltrações, corrosão dos condutores de águas pluviais, goteiras e etc.

No início dos anos 2000 a antiga usina diesel passa por nova intervenção. Novamente sem nenhum projeto, o tratamento das superfícies é realizado, juntamente com a remoção de algumas inserções modernas e a demolição de um pequeno depósito de materiais em anexo.

\footnotetext{
${ }^{9}$ SOROCABA (SP): Processo $n^{\circ} 20.480 / 91$, p.30.

${ }^{10}$ SOROCABA (SP) Processo $n^{\circ} 20.480 / 91$, p. 82.
} 


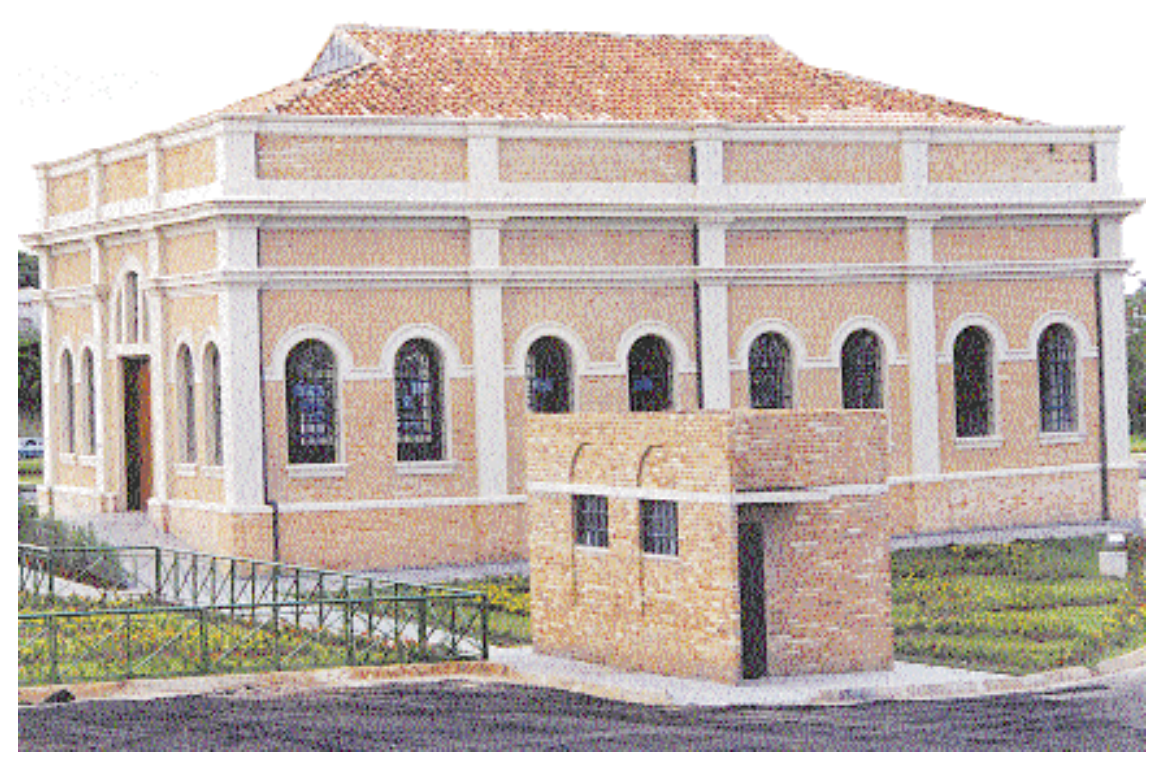

Figura 74: Usina Cultural Ettore Marangoni, após as intervenções. Fonte: JORNAL CRUZEIRO DO SUL, 4.4.2000, p. A-1.

Com o término das obras, a Prefeitura estabelece um acordo com a CNE, onde o prédio foi doado à municipalidade recebendo o nome de "Usina Cultural Ettore Marangoni". Atualmente tem sido usada para exibição semanal de filmes (Projeto Usina Cine Cult) e eventos culturais diversos, tais como: apresentações musicais, teatrais, lançamentos de livro e palestras. Por apresentar um exíguo tamanho, poucos usos seriam compatíveis com o local. E esse uso foi acertado, uma vez que respeita as características espaciais do local. O único problema é que este uso não é contínuo (é usado uma ou duas vezes na semana, passando a maior parte do tempo fechado).

\section{Fábrica Santa Rosália}

Foi Fechada em 1994. Em 1997 iniciam estudo para tombamento do conjunto dos edifícios fabris, excluindo o bairro e a vila operária destas análises. Durante o desenvolvimento dos pareceres dos conselheiros do CMDP sobre a pertinência ou não de todo o conjunto é decidido apenas propor o tombamento do edifício principal da fábrica. O Conselho exclui os edifícios da subestação de energia, da creche e depósitos. Fundações primitivas de pedra (das paredes internas) são demolidas também. 0 
Maquinário têxtil, inclusive o antigo locomóvel (enorme maquina movida a vapor que gerava energia para os antigos teares no período em que a fábrica não era eletrificada), foi vendido como sucata para um ferro-velho ${ }^{11}$.

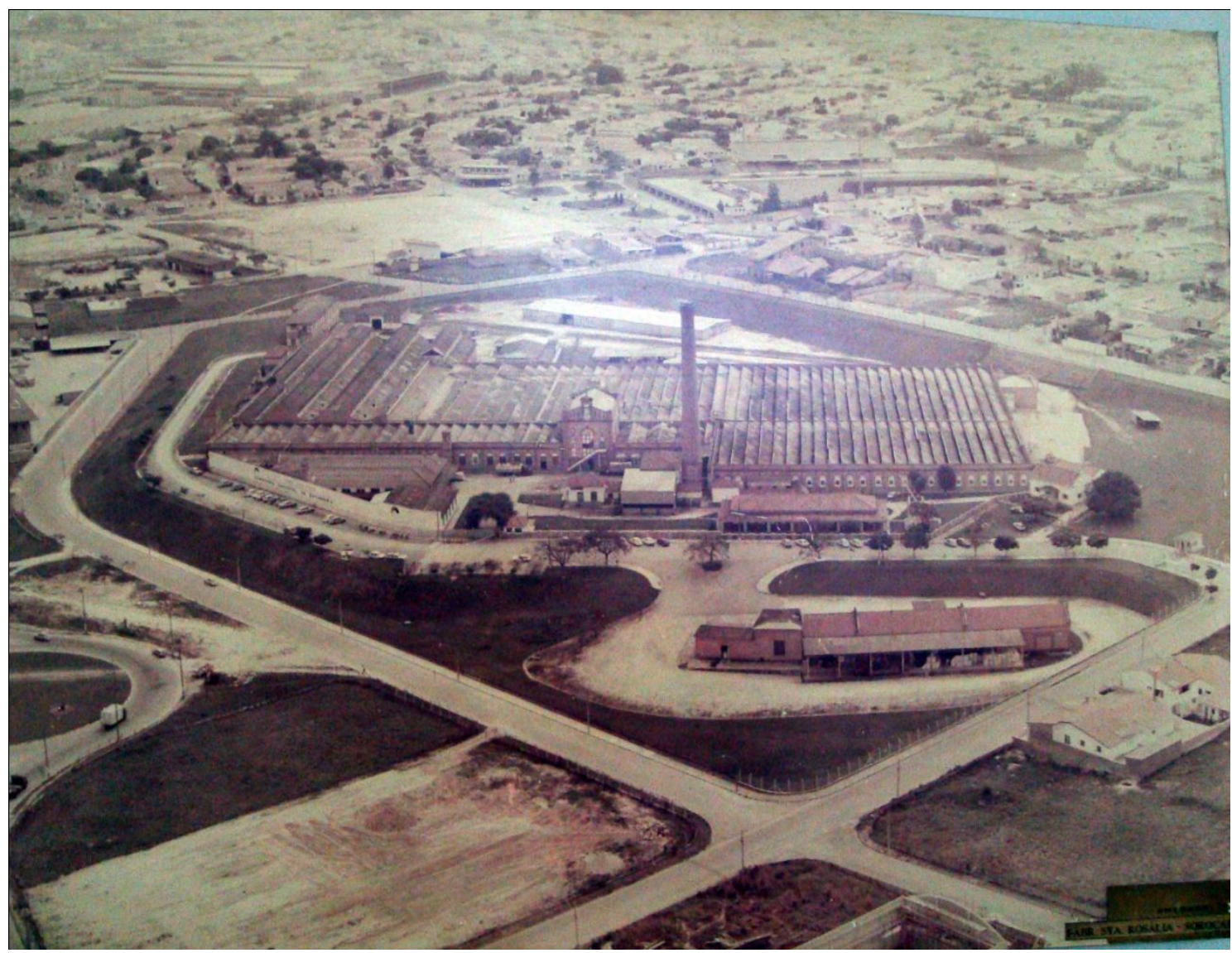

Figura 75: Fábrica Santa Rosália, vista aérea, década de 1970 (?). Fonte: CNE.

Em 1999 a fábrica foi leiloada e comprada pelo Grupo Pão de Açúcar, com o intuito de transformá-la em um hipermercado

No mesmo ano o edifício foi tombado e recebeu o grau de preservação GP-2, que em teoria é o grau de proteção que impede quaisquer modificações na volumetria do edifício. Na prática, apenas as fachadas foram preservadas. A cobertura foi completamente substituída.

\footnotetext{
${ }^{11}$ Conforme depoimento de Sonia Nanci Paes, ex- chefe da SPHAC.
} 
Neste caso ficou evidente a imposição de um projeto pré-concebido dentro de um edifício a ser preservado. O bem se adaptou ao uso e não o contrário (o uso se adaptou ao bem). A cobertura original do edifício foi considerada baixa para os padrões de supermercados do Grupo Pão de Açúcar, sendo totalmente descartada. O pé-direito do edifício foi ampliado, modificando completamente a volumetria, que em teoria deveria ser mantida. Trocaram os sheds, por coberturas planas, acoplando uma nova platibanda metálica.

Internamente tudo foi demolido. A justificativa para isso foi de que a modulação da estrutura existente não se ajusta aos tamanhos pré-determinados dos corredores, gôndolas e caixas do hipermercado. E tudo com anuência, ou a conivência do CMDP.

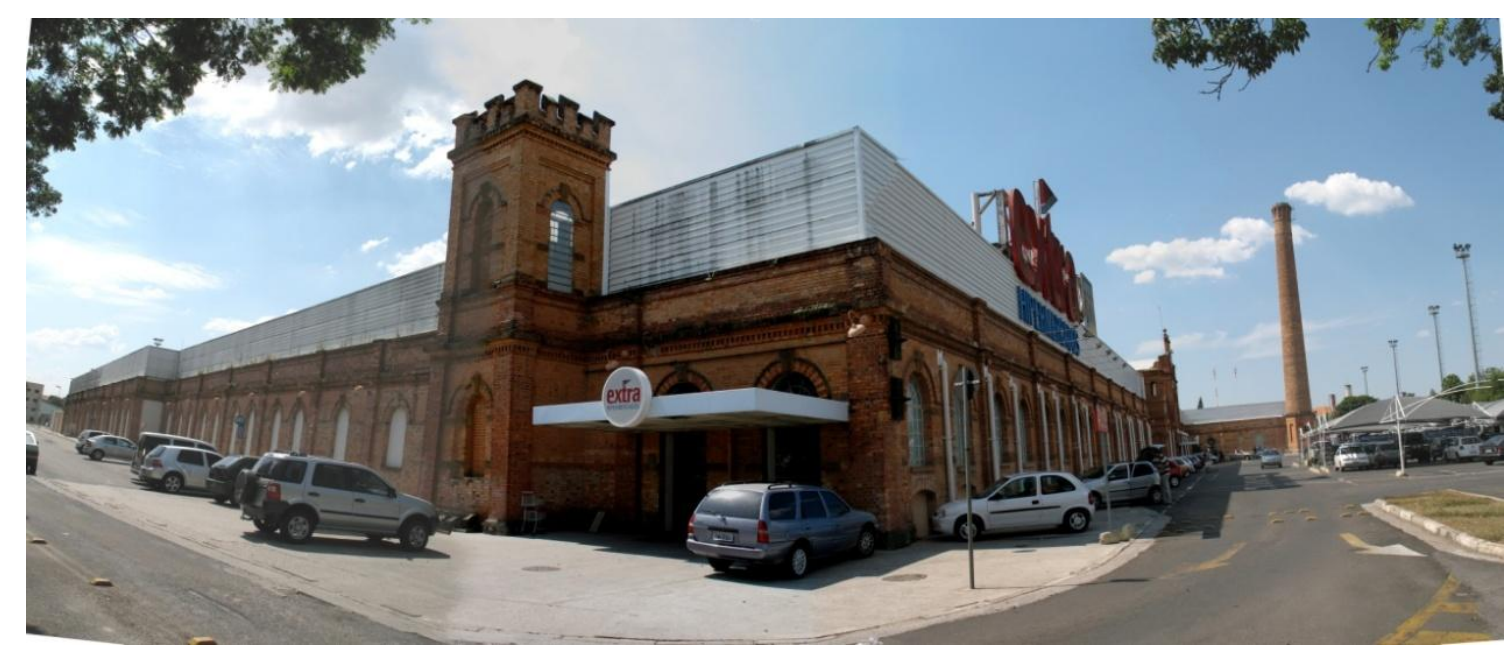

Figura 76: Hipermercado Extra Santa Rosália, 2008. Fonte: do autor

A sensação estranha ao adentrar no empreendimento é a seguinte: por fora, um edifício antigo, singular (mesmo que alterado) e repleto de aberturas. Por dentro, um hipermercado como outro qualquer (genérico), exceto pelas fotografias antigas do bairro e da entrada principal, que manteve parte das características do edifício primitivo. Fora isso é impossível sabermos que estamos dentro de um edifício de tamanha importância histórica, uma vez que foram construídas paredes novas por detrás das paredes originais do edifício, bloqueando não só a visualização das mesmas, como também a entrada de iluminação natural pelas janelas, que também foram encobertas por dentro. Como as coberturas originais (sheds), que proporcionavam 
uma abundante iluminação natural, foram removidas, o novo edifício é ininterruptamente iluminado artificialmente. Fato também curioso e contraditório é a questão da espacialidade interna. Apesar do hipermercado ser um grande espaço aberto, que condiz com a espacialidade do edifício primitivo, em diversas partes foram alocadas seções administrativas e/ou de armazenamento, criando uma série de compartimentações que anulam este aspecto de amplitude. Ora, pois, se anteriormente haviam edifícios que faziam parte do conjunto da fábrica, em bom estado de conservação, estes mesmos espaços poderiam continuar existindo. Senão vejamos: o antigo depósito - poderia ter sido usado como local para armazenamento; a antiga creche - poderia tanto ser utilizada como um espaço de recreação para pais que fossem fazer compras e precisassem levar seus filhos; ou mesmo, continuar sendo espaço de creche para funcionários; a administração, também poderia funcionar no espaço onde anteriormente teria sido espaço da creche. Enfim, não era necessário a demolição destes espaços. O que foi justificado teria sido a necessidade de aumentar o número de vagas de estacionamento (algo também desnecessário devido o tamanho da área disponível para tal tarefa).

\section{A vila operária/bairro:}

Com a falência da CNE todos os imóveis do bairro, que pertenciam à companhia, foram sendo vendidos paulatinamente e hoje apenas a antiga escola SENAI, a Paróquia de Santa Rosália e o Armazém, ainda existem e estão bem conservados. As antigas residências não mais possuem características que possam ser reconhecidas como as antigas casas da vila operária. Contudo a maior modificação que o bairro sofreu será descrita a seguir.

\section{O Shopping Villàgio Santa Rosália}

Um caso bastante complexo e controverso que ocorreu nestes quatro últimos anos se refere à demolição do antigo Ginásio e do Cine-Teatro de Santa Rosália para a construção de um centro de compras (Shopping Center). 
Localizados junto à Praça Pio XII, as duas construções compunham, juntamente com o armazém, o grupo escolar, a escola SENAI, a Igreja de Santa Rosália e a Congregação Mariana, um conjunto de edificações voltadas para as atividades sócio-culturais e educacionais dos moradores, possuindo assim um grande significado para a compreensão de como era o bairro operário. Como cada uma das construções foi edificada em períodos distintos, possuíam características arquitetônicas díspares (ex.: o grupo escolar, da década de 1920, era um edifício de alvenaria de tijolos aparentes assentados com um alto grau de sofisticação; o Ginásio, da década de 1940, um edifício sóbrio e sem adornos - característica dos edifícios escolares de tal período; o Cine-Teatro, da década de 1950, era um edifício moderno, o único exemplar do bairro com tais características) que se relacionavam de maneira harmoniosa, tanto pela implantação, quanto pelo porte das construções.
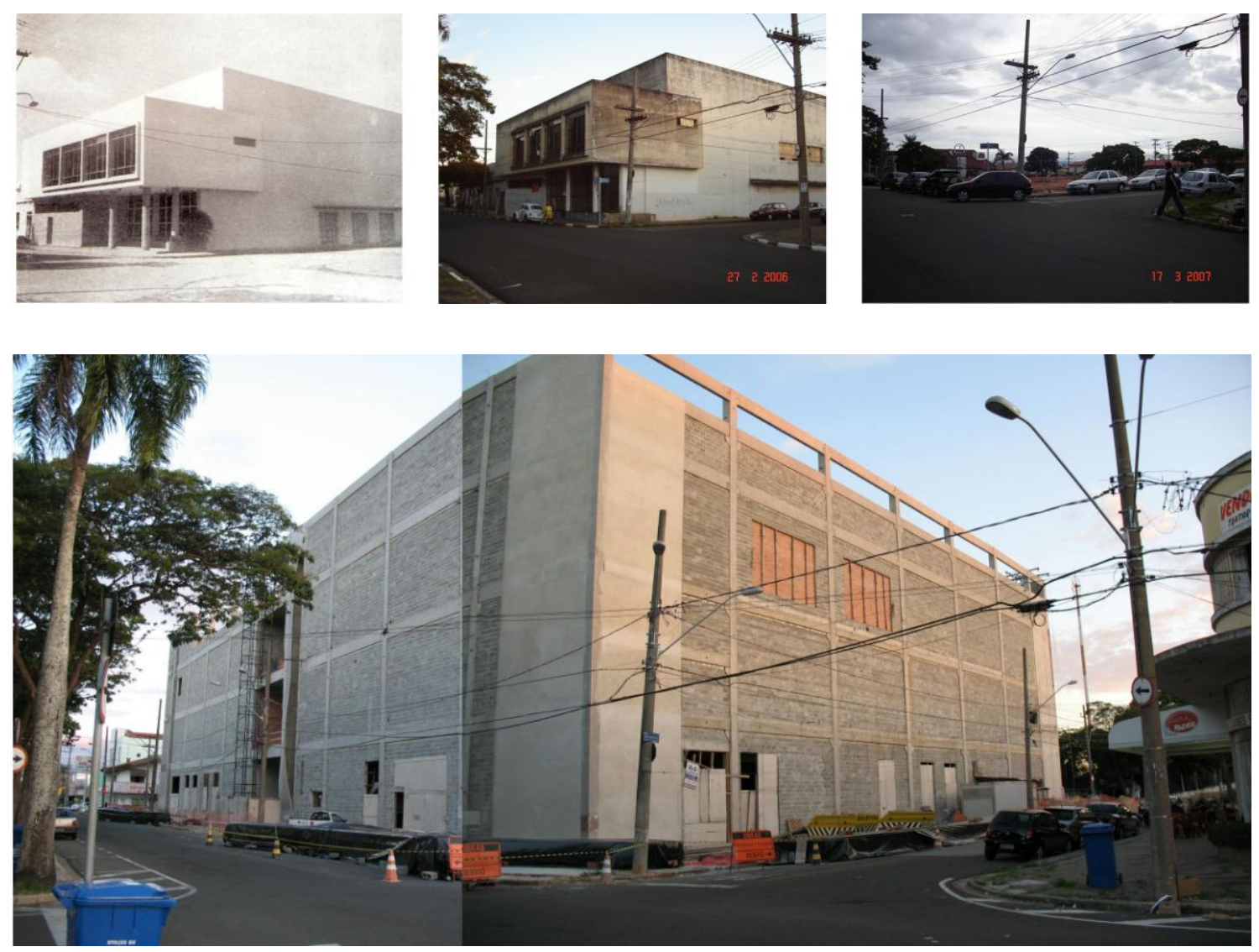

Figura 77: Acima - antigo Cine-teatro Santa Rosália, em 1959, 2006 e 2007. Abaixo Shopping Villàgio em construção, 2010. Fonte: do autor. 
O edifício do Ginásio, com seu grande recuo frontal e lateral, demarcava de forma destacada a esquina entre a Praça Pio XII e a Avenida Pereira da Silva. O Cine-Teatro, cuja fachada principal era voltada para a praça, fora construído parcialmente no alinhamento da calçada, apenas com sua entrada principal recuada, marcada pelo terraço apoiado em pilotis, também se destacava levemente das demais construções.

Abandonados há mais de vinte anos, ambos os edifícios estavam deteriorados, vandalizados e apresentando patologias tais como: infiltrações, desprendimento das argamassas de revestimento, madeiramento corroído por cupins, e etc.

No ano de 2006, o empresário Sérgio Rocco, morador do bairro, adquire ambos os imóveis com o intuito de "revitalizá-los" ${ }^{12}$, transformando o antigo Ginásio em um centro de compras e o Cine-Teatro em um cinema. Para o desenvolvimento destes projetos, foi contratado o escritório Botti Engenharia e Construções Ltda ${ }^{13}$. Após o desenvolvimento dos projetos, o empreendedor realizou uma pré-venda das unidades comerciais. De acordo com depoimento do próprio empresário, todas as unidades foram comercializadas em uma tarde, causando um grande perplexidade em todos os responsáveis pelo seu desenvolvimento.

Devido a essa tamanha repercussão das vendas imediatas de todas as lojas e espaços comerciais do empreendimento, Sérgio Rocco decide abandonar o projeto inicial de intervenção e substituí-lo por um edifício novo e muito maior, um Shopping Center. É exatamente nesta mudança de rumos que se iniciam minhas considerações.

Primeiramente, é interessante notarmos como um empreendimento, que em seu conceito inicial propunha a reutilização de dois edifícios importantes para o bairro de Santa Rosália, muda de planos rapidamente quando a questão econômica passa ser a única e exclusiva questão a ser priorizada. É evidente que a questão econômica faz parte de um conjunto de elementos que devem ser solucionados para que a

\footnotetext{
${ }^{13}$ Escritório que havia se notabilizado na cidade após uma intervenção (duvidosa) em um antigo casarão na área central, transformado em restaurante.
} 
intervenção seja bem sucedida. Todavia, esta questão não pode (ao menos não poderia) ser a única questão a ser levada em consideração. A questão cultural, que deveria ser principal, quando o assunto é intervenções em bens culturais, passa a ser coadjuvante, num universo regido pela especulação imobiliária.

É justamente neste ponto que muitas perguntas surgem: Estes imóveis não estão localizados em uma praça tombada? O projeto do Shopping foi aprovado pelo CMDP? Como foi a reação dos moradores locais com esta impactante mudança no bairro?

Apesar de tombada, a Praça Pio XII, não possui área envoltória que limite ou restrinja algum tipo de construção ou intervenção no tecido urbano local. No histórico do processo de tombamento da praça, podemos observar que anterior ao pedido de tombamento ${ }^{14}$, consta um projeto de lei ${ }^{15}$, de autoria do então vereador José Francisco Martinez, que procurava estabelecer uma proibição de novas construções no até então denominado corredor comercial Pereira da Silva, que tinha como justificativa o seguinte texto:

\footnotetext{
"A propositura visa coibir a construção de edifícios no corredor comercial Pereira da Silva, antigamente Zona Residencial, hoje corredor comercial. O padrão das residências e os estabelecimentos comerciais estão harmonizados. Pretende-se, portanto, a manutenção dessa situação com a redação proposta" ${ }^{16}$.
}

Em carta anexa ao processo ${ }^{17}$, o Sr. Salvador de Cápua, chefe de Seção do Patrimônio histórico e Cultural, da Secretaria da Cultura da Prefeitura Municipal de Sorocaba, relata a visita do Promotor de Justiça da Curadoria do Meio Ambiente e do Patrimônio Histórico, Dr. Jorge Alberto de Oliveira Marum, onde o mesmo sugeriu a salvaguarda da praça e a inclusão de alguns elementos ao processo de tombamento: "o Coreto, $o$ ponto de ônibus e o paisagismo ali existente..." e "constar da resolução do CMDP o raio envoltório demarcando na aero-foto, a paróquia de Santa Rosália... o antigo Cine Santa Rosália e os imóveis fronteiriços com a Praça incluindo o trecho da Av. Pereira da Silva

\footnotetext{
${ }^{14}$ Resultante de um abaixo assinado elaborado pelos moradores do local (PROCESSO № 14399/97, pp. 31-117).

${ }^{15}$ PROJETO DE LEI № $136 / 2000$.

${ }_{16}^{16}$ PROJETO DE LEI № $136 / 2000$.

${ }^{17}$ PROCESSO № $14399 / 97$, p. 26.
} 
e Av. São Francisco, definindo gabarito e volumetria das futuras construções $e$ ampliações no raio abrangente" ${ }^{18}$.

Apesar de todas estas tentativas de estabelecer critérios abrangentes, visando um tombamento digno para o local, o conselho estabeleceu que a Praça Pio XII seria tombada com grau de preservação GP4 (grau de proteção aplicado a casos de tombamento de parques, reservas, áreas verdes e compreende a preservação de todo o patrimônio natural existente no local). Apesar de a praça ser composta por diversas espécies vegetais, jardins e paisagismo característico, não se pode confundir este caso, que é uma de praça tipicamente urbana, onde todas as edificações que a circundam promovem uma ambiência e harmonia, com uma área natural, como um parque ou reserva, ou seja, trata-se de um tombamento indistinto, mal elaborado e equivocado. Soma-se isso à questão da área envoltória, onde estabeleceram que seria somente o limite da própria praça, "não contemplando as edificações do entorno" ${ }^{19}$, ou seja, apenas a praça com seu piso, vegetação, coreto, ponto de ônibus e monumento ao industrial Pereira da Silva. O Órgão que deveria estabelecer critérios e discussões visando à preservação agiu em detrimento dela.

Também é digno de menção o levantamento histórico da praça juntamente com o texto de justificativa de sua preservação contidos no processo de tombamento. Apesar de relacionarem o surgimento da Praça Pio XII ao bairro operário da Fábrica Santa Rosália, em nenhum momento esta conexão foi adotada para o estabelecimento de políticas preservacionistas, vinculando os edifícios de produção de tecidos com todos os outros edifícios existentes, que eram necessários para o funcionamento da fábrica e a manutenção de um status quo, onde os funcionários pudessem viver sem a necessidade de se deslocarem para o centro da cidade de Sorocaba.

Não possuindo uma adequada proteção, os edifícios do ginásio e do antigo Cine-Teatro Santa Rosália foram demolidos em fevereiro de 2007. O Shopping foi aprovado pelo poder público municipal sem nem sequer precisar ser aprovado pelo CMDP. Aliás, não

\footnotetext{
${ }^{18}$ PROCESSO № 14399/97, Op. Cit. p. 26.

${ }^{19}$ PROCESSO № 14399/97, p. 54.
} 
só a questão da preservação de bens culturais foi negligenciada, como também às de caráter urbanístico. Não é necessário grande esforço para imaginar tamanho impacto que a construção de um Shopping Center de 30 mil metros quadrados, com 98 lojas, três subsolos de estacionamento com capacidade total para 500 carros, praça de alimentação, quatro salas de cinema e uma estimativa de 450 mil pessoas/mês de público pode causar em um bairro estritamente residencial.

Fato paradoxal e intrigante é a "roupagem" que se procurou oferecer ao edifício do Villàggio Shopping: a adoção de um visual comumente chamado de "neo-clássico". Destrói-se o antigo para dar lugar ao novo, mas um novo que tenta evocar ou citar (mesmo que de maneira equivocada) o antigo. Outro fato curioso são os murais colocados em frente às lojas que ainda não foram inauguradas: todos padronizados e decorados com fotografias antigas do bairro, em especial dos antigos prédios que foram destruídos para dar lugar ao shopping. Mas, se estes edifícios são tão importantes a ponto de merecerem esta "homenagem" porque foram demolidos? Este fato se tornou marca registrada da "demagógica" preocupação em se preservar a história local, podendo ser observado nos murais contidos no Hipermercado Extra, em todos os seus concorrentes e em outros edifícios de interesse histórico/cultural, parte demolidos por completo, parcialmente demolidos ou completamente descaracterizados.

Em matéria publicada no Jornal Cruzeiro do Sul de 25.11.2010, tratando da inauguração do novo empreendimento comercial, os moradores do bairro se mostraram divididos em suas opiniões sobre o Shopping Villàgio. Enquanto parte deles estava bastante animada com a vinda do shopping, pois traria para o local uma grande valorização imobiliária, a outra parte dos moradores estava muitíssimo descontente com a implantação do shopping devido a todo o transtorno causado pelas obras, além de todo o novo e intenso movimento que o bairro adquiriu. Os descontentes também frisaram que sentem medo de, pouco a pouco, o bairro ir se tornando comercial em diversos pontos, trazendo muitos inconvenientes como barulho, falta de locais para 
estacionar os veículos e principalmente a descaracterização daquele bairro que outrora fora operário.

É importante salientar que boa parte dessas mudanças e inconveniências que os moradores se queixaram, foram iniciadas em meados da década de 1990, quando a Avenida Pereira da Silva passou a ser um Corredor Comercial, iniciando um caminho sem volta de destruições, demolições e descaracterizações em toda a antiga vila, uma vez que boa parte das casas dos antigos funcionários se localizava na própria avenida. Claro está que, anterior a esse fato, muitos moradores novos, ou até mesmo herdeiros dos antigos donos das casas, trataram de reformá-las ou ampliá-las, sendo fato mais comum a criação de garagens para automóveis. Contudo, o que mais chama a atenção nessas reformas ou ampliações é a necessidade de distinção entre as residências: parece haver um ímpeto das pessoas em distinguir sua residência das demais, uma vontade incontrolável de se fazer ser visto, causando uma heterogeneidade entre elas, apagando aquilo que elas possuíam de mais belo, que era a harmonia do conjunto.

Logo após esta mudança no zoneamento da avenida, este comportamento foi acentuado pela instalação de escritórios, lojas, boutiques e outros tipos de empreendimentos que ali se implantaram sem a mínima intenção de se adequar ao existente. Muito pelo contrário, o que se procura em cada novo empreendimento é se sobressair perante os demais, aniquilando, assim o pouco que havia restado das antigas residências para funcionários (tanto as dos operários, quanto as dos gerentes).

É devido a todas essas insensatas mudanças que os moradores procuraram se unir para agrupar um número significativo de assinaturas visando o tombamento da Praça Pio XII, relatado acima. Foi através deste apelo popular que se abriu um processo para que ela fosse tombada (infelizmente, de maneira inadequada). Constatamos que muitos moradores ou antigos funcionários não residem mais lá. Muitos faleceram. Outros, nunca tiveram este "apego" pelo local. Os que ainda moram são muito idosos e já desistiram de lutar contra estes fatos. O que vemos em geral são herdeiros ou mesmo novos moradores, sem qualquer ligação afetiva ou até mesmo sem nenhuma 
preocupação com a preservação desta história e destes bens. O que antigamente era uma das características mais intrigantes do local, a diversidade e a heterogeneidade das classes sócio-econômicas, vivendo em harmonia (desde a década de 1970 quando o loteamento Santa Rosália é inaugurado, visando um público de classe média-alta): operários (desde os mais simples até os mais altos cargos), comerciantes, médicos, advogados, industriais, pessoas das mais díspares condições financeiras residindo no mesmo local, sem barreiras ou distinção. Isto foi, pouco a pouco, desaparecendo, desde a falência da fábrica. Com todas estas mudanças, os que ainda residem no bairro, são famílias de classe-média alta. O que antes era um bairro estritamente residencial, hoje é um bairro praticamente de uso misto. O que a princípio não seria problema algum, a mudança de uso, se tornou um "inimigo" da preservação histórica do bairro, devido à falta de planejamento com que estas mudanças foram colocadas em prática.

\section{O Caso da Chácara Sônia Maria}

Seguindo a mesma problemática das outras antigas propriedades da CNE, a Chácara Sônia Maria também fez parte de negociações intermediadas por bancos credores e/ou dívidas junto ao INSS e à PMS incluindo questões ligadas a IPTU.

Em 1999, o imóvel, que compreendia uma área de aproximadamente um hectare, juntamente com a antiga Mansão Pereira da Silva, foi leiloado. Seu arremate foi conseguido por uma multinacional francesa do ramo de hipermercados.

A Câmara dos Vereadores imediatamente após a divulgação da notícia mobilizou-se, no sentido de analisar se o empreendimento traria grandes impactos para aquela região da cidade, principalmente no que se refere a questões ambientais.

Por intermédio de um grupo de vereadores é aberto um inquérito junto ao Ministério Público para verificar a pertinência de preservação do imóvel e da vegetação local. A 
Câmara dos vereadores se mostrou dividida argumentando de um lado pela preservação do local e de outro pela criação de empregos.

O CMDP questionado pelo MP atestou que os imóveis em questão não eram merecedores de qualquer tipo de preservação, sendo sugerida a elaboração de maiores estudos referentes à pertinência da proteção de todas as áreas verdes e os impactos ambientais da instalação de tal estrutura.

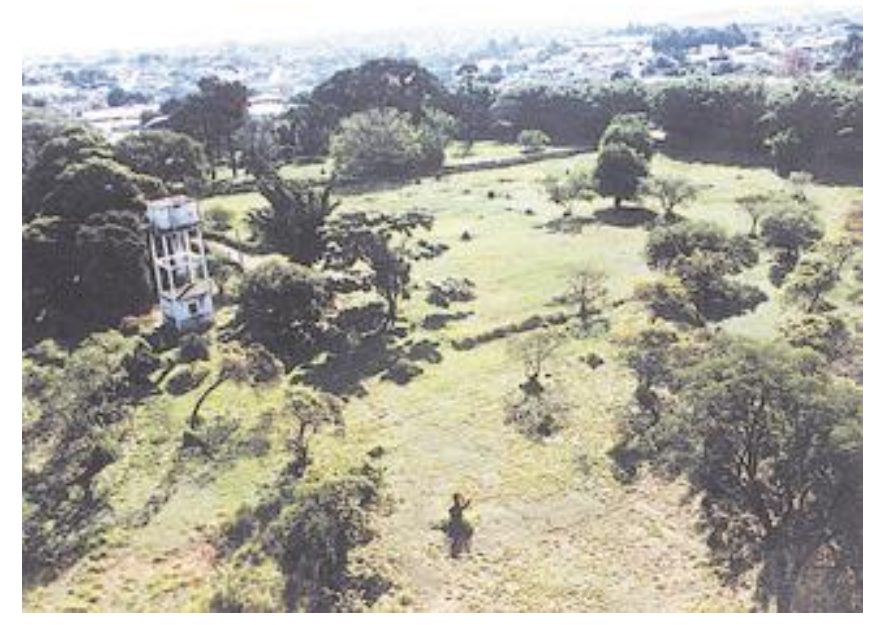

Figura 78: Chácara Sônia Maria, vista aérea. Fonte: JORNAL CRUZEIRO DO SUL, 20.7.1999, p. A-6.

Com isso, o MP acaba concluindo que não havia impedimentos legais para barrar tal projeto, uma vez que os empreendedores se comprometeram a preservar toda a mata que fosse nativa, além de construir um reservatório para captação de águas pluviais, a fim de impedir qualquer impacto ambiental. A mansão foi demolida.

Coincidência ou não, de forma intrigante na mesma página do jornal que noticiou a liberação do Ministério Público para a construção de um hipermercado na Chácara Sônia Maria, uma enorme propaganda do mesmo hipermercado toma a página por completo. De forma irônica e patética, lado a lado, a notícia do Ministério Público e a de um anunciante do jornal (Carrefour), demonstrando mais uma vez de que lado está a força do poder econômico. Por detrás da imagem de um anúncio há outros tipos de mensagem ${ }^{20}$. Se de um lado há cidadãos tentando preservar a área da Chácara Sonia

\footnotetext{
${ }^{20}$ DEBRAY, R. Vida e Morte da imagem - Uma História do Olhar no Ocidente. São Paulo: Ed. Vozes, 1993.
} 
Maria; de outro, o anúncio do jornal de forma mais sutil está a seduzir que um hipermercado poderá trazer boas ofertas, bons produtos e maiores "vantagens" aos munícipes daquela região. Um anúncio desse tipo, coincidentemente ao lado da notícia de que não havia impedimentos legais para a construção de um hipermercado na região, pode sugerir subliminarmente que um empreendimento daquele porte é melhor que um parque juntamente com a preservação do imóvel da chácara, que poderiam ter outro tipo de uso.

Se de um lado há cidadãos tentando preservar a área da Chácara Sonia Maria; de outro, o anúncio do jornal de forma mais sutil está a seduzir que um hipermercado poderá trazer boas ofertas, bons produtos e maiores "vantagens" aos munícipes daquela região. Um anúncio desse tipo, coincidentemente ao lado da notícia de que não havia impedimentos legais para a construção de um hipermercado na região, pode sugerir subliminarmente que um empreendimento daquele porte é melhor que um parque juntamente com a preservação do imóvel da chácara, que poderiam ter outro tipo de uso. 


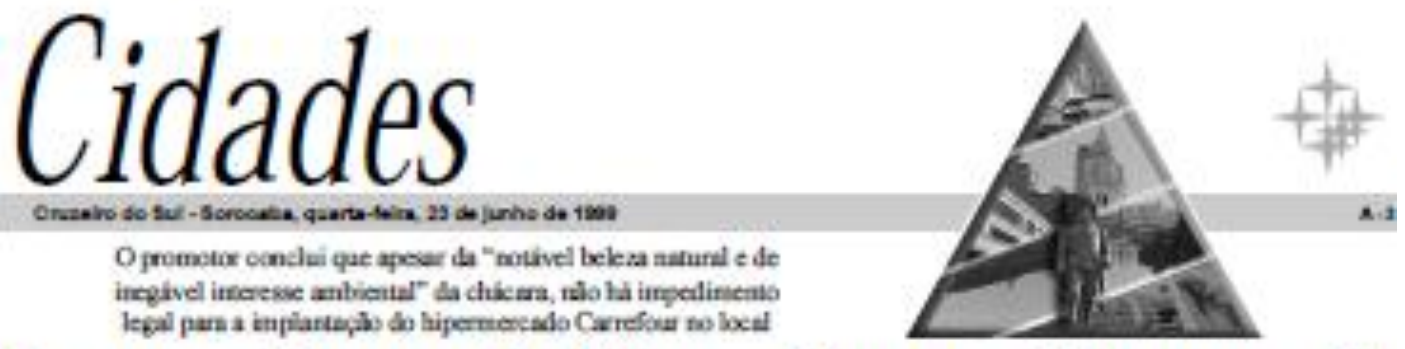

\section{Promotor diz que não há impedimento a hipermercado}

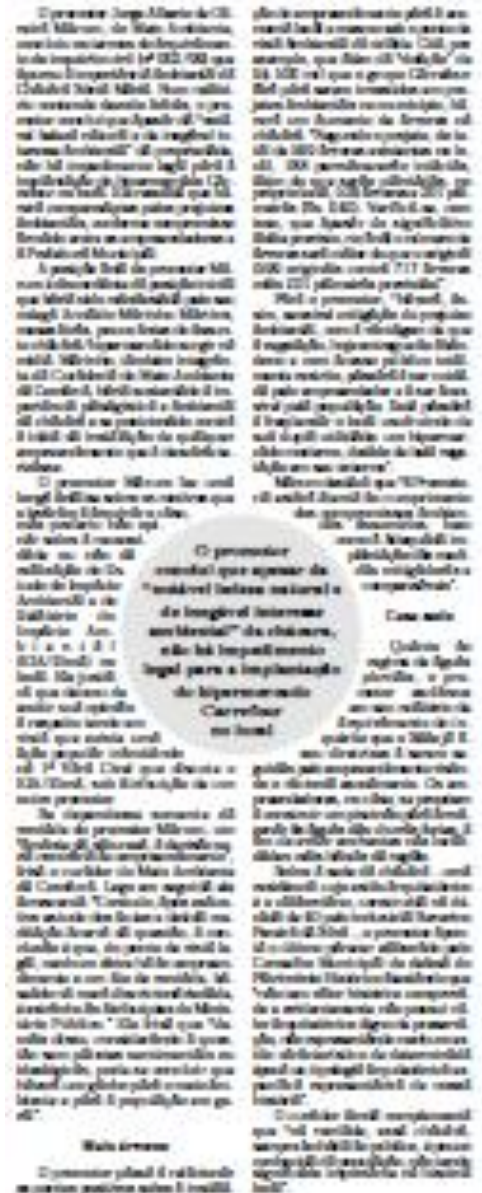

Notes

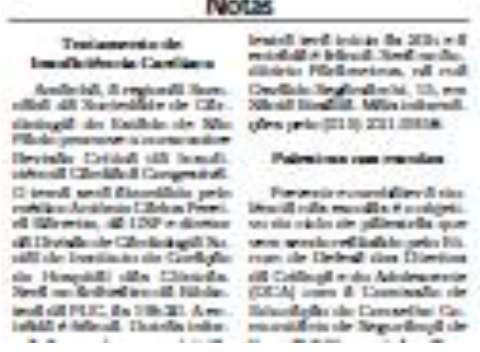

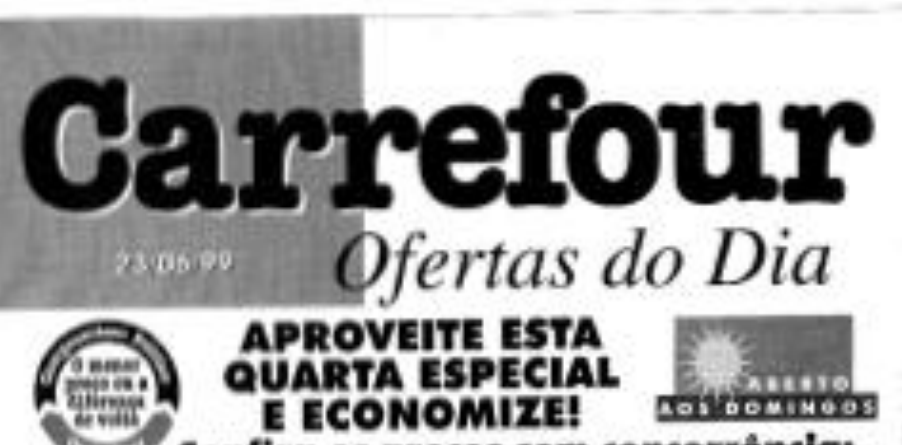

Confira os precos sem concorrênciat

ciwu inesa a iase.

Misor gawn i tive.

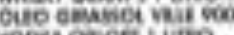

mogu onow inno

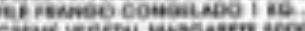

Cabvi verwa hacantn

ho or fonia wick oos une

novoris ineacose

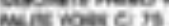

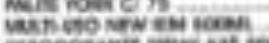

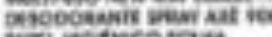

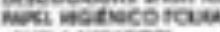

bura verahon

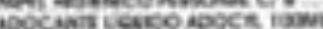

cocicou miturios

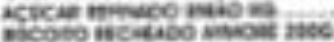

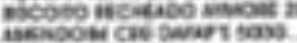

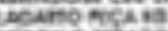

ascilo nitaco as

undo

nopeane hinetci :

there ovian.

warn

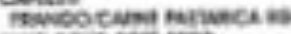

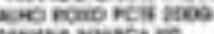

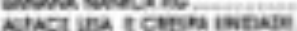

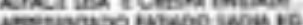

mismes frimco jackic.

inelaca cenert:

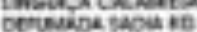

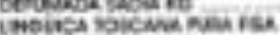

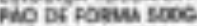

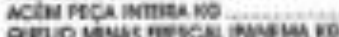

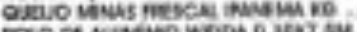

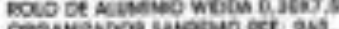

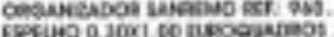

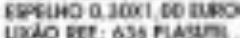

undo ket: 635 FWow

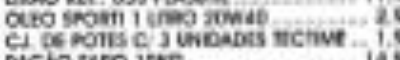

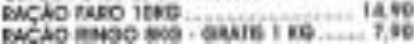

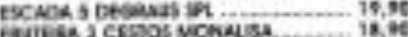

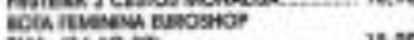

wes $[3+20 \mathrm{sh}$ - 18,

Mis i pontwas ocas

uncol watso nexor cow Haince

CAEN

Noliswo

as:ac

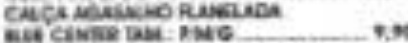

surous Crusua poctal becsuon ats

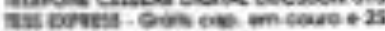

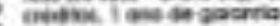

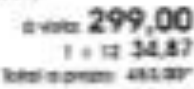

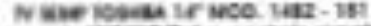

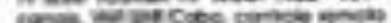

$\sin =279,00$

$1+912.53$

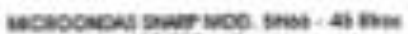
menowes tidise as

$4=258,00$

$1+1239.09$

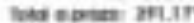

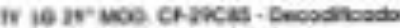

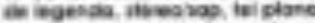

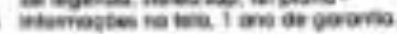

a was 699,00

$1=12 \mathrm{Bi}, 5$

bivi a pasas iassed

computapos mis uet cmis bas won

ing. limb on bus nanas la

mextreat $\operatorname{axx}$

vense $1,489,00$

$\{, i a 1,3,63$

toreta beos zasias

Figura 79: JORNAL CRUZEIRO DO SUL, 23.6.1999, p. A-3. 
Por fim, dentre todas as incoerências e os problemas apresentados durante esta pesquisa, uma questão estarrecedora e que sintetiza o panorama da preservação de bens culturais em Sorocaba, foi confrontar a logomarca adotada pelo CMDP, seu significado e ao mesmo tempo a realidade do tratamento dado ao patrimônio ao qual ele simboliza.

O Símbolo do Conselho foi criado pelo arquiteto Ricardo Bandeira, quando este era um dos conselheiros, em 1997. Apesar de simples, o logotipo é bastante eficaz em sua analogia com os sheds das antigas fábricas têxteis. Consegue traduzir a importância daqueles elementos (os sheds para as fábricas e as fábricas para a história da cidade) de uma maneira bastante criativa.

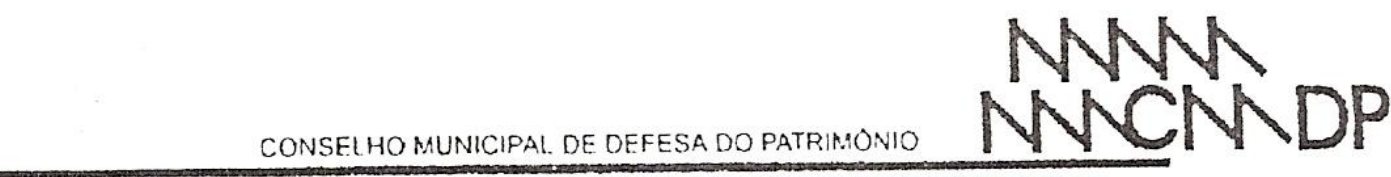
Historico. Artístico. Arquitelonico, Turistico e Paisagíslico de Sorocaba

Figura 80: Logotipo do CMDP. Fonte: CMDP - Resolução n 112 de 15 de Setembro de 1999.

Este símbolo poderia ser a casa bandeirista onde hoje é o Museu Histórico Sorocabano; poderia ser qualquer objeto que fizesse menção ao tropeirismo, uma vez que este ciclo econômico foi responsável por todo o desenvolvimento da cidade durante os séculos XVIII e parte do XIX; poderia ser algo que representasse o Mosteiro de São Bento, a edificação local mais antiga. Ao invés disso, escolheram como símbolo algo ligado ao patrimônio industrial, por, ainda, ser um marco referencial na paisagem urbana de Sorocaba.

Mas, a postura adotada pelo órgão para com a preservação deste patrimônio não faz jus ao símbolo. Diante de demolições criminosas, tombamentos indistintos, falta de critérios nas decisões a respeito do que deve ser preservado e conivência com projetos de intervenção deturpadores, fica claro que a preocupação em salvaguardar estes preciosos bens para as futuras gerações, não passou de aparente "atitude de fachada" 
Portanto, apesar da força do símbolo, o mesmo não foi capaz de ter eficácia no sentido de mobilizar as pessoas de forma necessária o suficiente, por uma luta pela preservação destes patrimônios.

Deste modo, o "símbolo pelo símbolo", acaba ficando sem significado, vazio. Trata-se do mesmo comportamento observado em outras manifestações na cidade, como os painéis e quadros com fotos antigas de edifícios ou locais que não foram preservados ou que foram completamente alterados, mas que buscam deixar uma imagem de cuidado em preservar a memória da cidade, mas que na verdade servem apenas como decoração. 
CONSIDERAÇÕES FINAIS

As indústrias têxteis da cidade foram, durante um grande período da história de Sorocaba, o centro econômico-social local: tudo girava em torno delas. E como vimos tiveram uma importância enorme como abertura do campo industrial de Sorocaba, sendo um marco referencial da paisagem urbana.

A falência das fábricas têxteis gerou um binômio: fim de uma era versus oportunidades de lucro imediato, visto que grandes áreas valiosas de terra ficaram nas mãos de empresários endividados. A conseqüência imediata deste binômio foi uma especulação imobiliária, seja através de acordo do pagamento das dívidas com os bancos, negociando essas áreas, seja negociando com órgãos públicos as dívidas de tributos devidos (municipais, estaduais ou federais). Aproveitando-se destas situações entram em cena elementos de ocasião, tais como: questões político-econômicas que levaram à implantação de um terminal de ônibus em local inapropriado, que seria de importância ímpar ao Patrimônio Industrial, mas que é apresentado como aparente solução ao transporte público e aos munícipes. Ao mesmo tempo outras medidas semelhantes levaram ou ainda podem levar à introdução de novos shoppings centers, apresentados como fontes de empregos. Mas preservar patrimônio também não pode gerar empregos?

Em termos de pensarmos numa fundamentação teórica podemos levar em consideração que em Sorocaba não houve distinção entre os exemplares do patrimônio industrial e os bens culturais "tradicionais". As indústrias, estações ferroviárias e outros bens relacionados à industrialização da cidade foram encarados como monumentos históricos como quaisquer outros. Os diversos problemas apresentados neste estudo procuraram mostrar parte de uma questão generalista, que engloba a atuação do Conselho local como um todo, e não apenas dos exemplares ligados à industrialização.

Foi relevante o estabelecimento de um importante órgão como o CMDP, que teve sua criação motivada pela iniciativa de amadores e interessados pela preservação, juntamente com a necessidade do poder público de regularizar uma situação insustentável - tombamentos provisórios por decreto. 
Este conselho ainda é formado apenas pelos representantes de entidades. Mas não dispõe de nenhum corpo técnico qualificado auxiliando no funcionamento do mesmo. Ao invés disso foi instituída a Seção do Patrimônio Histórico, que é administrada por pessoas também sem qualificação profissional para tanto. O CMDP procurou utilizar do instrumento jurídico do tombamento não apenas para preservar, mas também para impedir que a especulação imobiliária continuasse a destruir o restante das edificações antigas do centro histórico da cidade, independente da importância cultural que determinados bens possuíam. Algo que se tornou fato comum foram demolições de inúmeros imóveis antigos numa corrida contra o tombamento ("vamos demolir esta velharia antes que decidam tombá-la"). Fato intimamente ligado à falta de incentivos ao portador de imóveis de interesse histórico-cultural. A área central da cidade deveria fazer parte de um plano direto,r integrado com a questão da preservação, promovendo tais incentivos e assim evitando a especulação; fato esse que não foi devidamente cuidado.

Exatamente por não dispor de um corpo técnico, o CMDP demonstra um desconhecimento da existência de uma reflexão teórica acerca da restauração (campo disciplinar autônomo), ou ao menos conhecimento superficial da questão, o que gera interpretações equivocadas, observadas em inúmeros processos estudados nesta pesquisa, levando-nos a também questionar o conhecimento desses profissionais em relação à história e teoria da arquitetura e urbanismo também. Pudemos constatar através da leitura de processos de tombamento dos casos estudados, questões um tanto delicadas provenientes do órgão local, que expressavam exatamente pelo já exposto, exemplares que nem sempre mereceriam tombamento; e por outro lado, exemplares, que pesarosamente deixaram de ser tombados.

A falta de critérios metodológicos tanto no órgão de preservação quanto nas intervenções, resultando em incongruências e/ou ações ditas culturais, mas que na verdade não as são (por desconhecimento das recomendações internacionais e/ou não utilização das mesmas);

O resultado deste desconhecimento é a falta de critérios nas resoluções, recomendações e inventários elaborados pelos conselheiros, somados às intervenções danosas e deturpadoras dos pseudo-restauradores, que acabam se passando por atitudes culturais beneméritas, acolhidas pela população em geral de maneira acrítica, quando na verdade poderiam ser consideradas como atos contra a cultura. 
Observa-se que existem questões equivocadas em relação à percepção de restauro uma vez que teoria e prática divergem em seus métodos. Embora o CMDP exija claramente que para se intervir em bens tombados seja necessário projeto de restauro, na prática verifica-se que inúmeras intervenções são realizadas sem projeto algum, muitas vezes baseado em memoriais imprecisos e ou incoerentes, quando não, relatando técnicas de intervenções que poderão trazer danos futuros tanto estéticos - de percepção e apreensão - como relacionados ao tratamento de superfícies arquitetônicas.

Kühl enfoca que
"um aspecto de maior relevância é discutir o papel do restauro na sociedade contemporânea. Pode-se refletir sobre o tema através de sua relação com a técnica. Se a técnica for tomada em sua essência - e não num sentido redutor de tecnicismo- cientificidade, de tecnicalidade, de aparatos tecnológicos para exercitar determinadas tarefas -, e entendê-la como uma transformação autônoma da pratica [...], pode-se ver a preservação de bens culturais relacionada com a técnica." ${ }^{1}$

Muitas das intervenções aqui estudadas foram frutos deste tecnicismo reducionista, pois praticamente todas as questões que deveriam ser solucionadas através de um projeto de restauro eram resolvidas no próprio canteiro de obras, pelo "restaurador" sem qualificação teórica para tanto. Neste contexto, recai-se no problema do tratamento das superfícies arquitetônicas como uma questão a ser resolvidas única e exclusivamente pela técnica ao invés de ser pensado sob a perspectiva de um projeto de restauro de maneira crítica e fundamentada.

\begin{abstract}
"Na pratica de atuações recentes, só vez por outra se verifica maior consciência e sensibilidade nas propostas e nas operações, tanto na escala urbana quanto em edificações isoladas. $O$ que se observa, em geral, é a absoluta prevalência de critérios ditados pelo uso, para obter maiores lucros, para aparecer nos meios de comunicação, e guiados por interesses setoriais e imediatistas. Em relação às intervenções em bens de interesse cultural, tem se ampliado o emprego de termos como recuperação, revitalização, renovação e, mesmo, reciclagem e reforma, aplicados até para edificações de grande interesse artístico. São termos que refletem posturas conceituais inadequadas, pois se afastam das razões que motivaram a preservação e que procuram distanciar-se do conceito de restauro, encarado erroneamente como ato que tolhe a criatividade, com intuitos apenas restritivos, que inviabilizaria uma transformação para atender de modo adequado às necessidades atuais." ${ }^{2}$
\end{abstract}

\footnotetext{
${ }^{1}$ KÜHL, Beatriz Mugayar. Preservação do Patrimônio Arquitetônico da Industrialização: Problemas teóricos de Restauro. Cotia, SP: Ateliê Editorial, 2008, p.31.

${ }^{2}$ Kühl, Beatriz Mugayar. Op Cit, p.207.
} 
Portanto, fica clara que a postura sorocabana observada nos casos estudados demonstrou ter ocorrido uma inversão entre os meios (o uso) e os fins (a preservação). Os bens foram submetidos às transformações de caráter pragmático, ou seja, foram adaptados para receber usos pré-estabelecidos. Ao invés de estudar e analisar quais seriam os usos mais adequados para esses bens - alicerçando em projetos de restauro abrangentes -, o que ocorreu foi a inserção "forçada" de usos não procedentes ao patrimônio, usos que demandaram alterações tamanhas a ponto de modificar completamente a apreensão dos mesmos:

"O uso que será dado ao bem preservado é de suma importância para que a intervenção seja bem sucedida. A reutilização é a forma mais eficaz para garantir a preservação de um bem, pois um monumento sem uso deteriora-se de modo rápido, enquanto aquele mantido em funcionamento pode durar séculos. A utilização é essencial para a preservação, mas, a princípio, deveriam ser analisadas as características a serem conservadas e respeitadas, para, depois, definir uma função compatível com elas, e não o contrário, adaptar um dado edifício a um novo uso préestabelecido ou submetê-lo a transformações massificadas nem sempre de acordo com suas particularidades, cuja implementação será feita em prejuízo do próprio monumento histórico". ${ }^{3}$

A Questão cultural como coadjuvante, quando deveria ser a principal:

"[...] a preservação de bens culturais, como começou a ser entendida principalmente a partir de finais do século XVIII, fundamenta-se em razoes culturais num sentido latopelos aspectos estéticos, históricos, educacionais, memoriais e simbólicos - científicas pelo conhecimento que essas obras trazem em vários campos do saber, tanto para as humanidades quanto para as ciências naturais - e éticas - que direito temos de apagar os traços de gerações passadas e privar as gerações futuras da possibilidade de conhecimento de que esses bens são portadores -, voltando-se às variadas formas de expressão do fazer humano. Diferencia-se, pois, de ações de cunho pratico, que prevaleceram para qualquer obra legada por outras épocas até que a preservação se consolidasse como ato de cultura, quando se passou a dar uma atenção distinta a determinados tipos de bem nos quais se reconhecia um significado cultural. Em tempos recentes, as razões pragmáticas, muitas vezes disfarçadas de ações culturais, voltaram a prevalecer, mesmo em relação a obras reconhecidas legalmente como patrimônio cultural. Imperam razões que trazem benefícios materiais, esquecendo-se das raízes espirituais e humanísticas que motivam o campo. Ou seja, muitas das ações, hoje, são ditadas por questões utilitárias: pelo uso, pela especulação em busca de maiores lucros, para obter visibilidade na mídia, também com intuitos político-eleitorais (resultante de certas práticas político-partidárias atuais não da política entendida no sentido de uma administração pública voltada ao bem da coletividade), negando a origem, os objetivos e a própria essência da preservação como ato de cultura que tutela a memória e o conhecimento" ${ }^{\prime 4}$.

\footnotetext{
${ }^{3}$ KÜHL, Beatriz Mugayar. Questões Teóricas Relativas à Preservação da Arquitetura Industrial. Desígnio. São Paulo, v-1, no. 1, p.110.

${ }^{4}$ Kühl, Beatriz Mugayar. Preservação do Patrimônio Arquitetônico da Industrialização: Problemas teóricos de Restauro. Cotia, SP: Ateliê Editorial, 2008, p.30-31.
} 
Podemos nos reportar ao caso da Fábrica Santa Rosália que foi transformada em Hipermercado Extra, para exemplificar esse aspecto. Neste caso, ao invés de haver preservação de fato do monumento histórico, o que pudemos observar foi uma forma do poder municipal resolver vários problemas, entre outros, a questão das inúmeras dívidas tributárias que o imóvel tinha para com a Prefeitura. Havia interesses em movimentar a economia local e a cidade só contava com um hipermercado, mas em franca ascensão de consumo. Também havia interesses políticos, no sentido de trazer empresas de grande porte, para geração de empregos, e consequentemente votos, em futuras eleições. Todos esses problemas foram devidamente mascarados com uma embalagem de uma falsa vontade de preservar a memória operária/industrial local. $\mathrm{Na}$ realidade, o que observamos nessa aparente preservação foi um duplo "fachadismo". Esses aspecto foi por nós considerado, tanto pelo fato de que a preservação teve motivos outros adiante dos culturais (que prevaleceram sobre estes), quanto pelo fato de que em sua execução (embasada em parecer do CMDP) só se preocupou exatamente com a fachada do prédio.

A problemática questão do tombamento em conjunto e/ou tombamento urbano: a visão antiquada do CMDP para com os tombamentos;

Avaliando o tombamento de bens culturais realizado pelo CMDP em Sorocaba, percebe-se uma visão antiquada perante os atuais preceitos teóricos de preservação uma vez que

\footnotetext{
"os responsáveis pela preservação dos monumentos sorocabanos em escala municipal pautam suas ações em definições 'tradicionais' do que seja patrimônio histórico, artístico e cultural, identificando-o com monumentos isolados, de destaque no tecido urbano, ou ainda como local onde se passaram fatos e personagens de relevo para a história local, que se presta mais à celebração de uma história oficial do que à manutenção da memória local. A recorrente preservação de edifícios isolados, ressaltados por obras de restauro que valorizam o aspecto imponente, garantido pelos recursos de iluminação cênica, demonstram o interesse do poder público muito mais em enfatizar os aspectos formais das edificações, criando verdadeiros cenários, do que em torná-las parte integrante da dinâmica da cidade ${ }^{\prime \prime}$.
}

\footnotetext{
${ }^{5}$ CUNHA, Claudia dos Reis e. Op. Cit, p.147.
} 
Nos casos estudados, procuramos evidenciar que, para um completo entendimento da importância dessas obras para a história local, seria necessária uma visão em conjunto das fábricas com suas respectivas vilas operárias e dos demais edifícios a elas relacionados. Logo, devido ao CMDP utilizar protocolos de tombamento individuais, cada fábrica (com exceção da Alvejaria, Tinturaria e Estamparia São Paulo que não possui nenhum estudo para tombamento) foi tombada em isolado, não garantindo a preservação das relações entre os edifícios fabris, das vilas e bairros operários, dos inúmeros edifícios pertencentes à Companhia e, por fim das inter-relações entre as indústrias.

Finalmente, verificamos que o tombamento é, por muitas vezes, visto como um fardo para a população e, não como um prêmio. Algo que se tornou fato comum foram demolições de inúmeros imóveis antigos numa corrida contra o tombamento. Devido à falta de uma política pública de preservação municipal que conceda bons incentivos aos proprietários (ou locatários) de bens culturais - incentivos estes como isenções de IPTU (Imposto sobre a Propriedade Predial e Territorial Urbana), isenções de ISS (Imposto Sobre Serviços de Qualquer Natureza) para os prestadores de serviços relacionados com a manutenção, conservação ou restauração de bens, outros tipos de isenções a proprietários que mantêm uma manutenção constante e/ou conservação programada, definição de áreas estratégicas para a transferência de potencial construtivo, etc. - o desestímulo da população perante o tombamento persiste e órgãos como o CMDP (e também os órgãos ligados à preservação ambiental) são vistos como vilões do processo de "desenvolvimento" urbano. Mas apesar de toda essa trajetória de estudos e pesquisas não podemos perder nossas esperanças. 


\section{REFERÊNCIAS BIBLIOGRÁFICAS}

ALMEIDA, Aluísio de. Sorocaba, 3 séculos de História. Itu, SP: Editora Ottoni, 2002.

ALMEIDA, Aluísio de. História de Sorocaba. Sorocaba: Guarani, 1951.

ANDRADE, Antonio Luiz Dias de. Um Estado Completo que Pode Jamais Ter Existido. Tese (Doutorado em Arquitetura e Urbanismo) - Universidade de São Paulo, São Paulo, 1993.

ARGAN, Giulio Carlo. História da Arte como História da Cidade. 4ạ Edição. São Paulo: Editora Martins Fontes, 1998.

AZEVEDO, Israel Belo de. O Prazer da Produção Científica: diretrizes para elaboração de trabalhos acadêmicos. 7ạ Edição. Prefácio de Hugo Assmann. Piracicaba: Editora UNIMEP, 1999.

BACELAR, Carlos de Almeida Prado. Viver e Sobreviver em uma Vila Colonial: Sorocaba, Séculos XVIII e XIX. São Paulo: Annablume/FAPESP, 2001.

BADDINI, Cássia Maria. Sorocaba no Império, Comércio de Animais e Desenvolvimento Urbano. São Paulo: Annablume/FAPESP, 2001.

BASILE, Giuseppe. Breve Perfil de Cesare Brandi. Desígnio, 2006 (2007), n.6, pp. 49-56.

BENEVOLO, Leonardo. A História da Cidade. 4ạ Edição. São Paulo. Editora Perspectiva, 2005.

BIBLIOTECA SOROCABANA: HISTÓRIA, VOLUME 1. Vários Autores. Sorocaba, SP: Crearte, 2005.

BLAY, Eva Alterman. Eu não tenho onde morar: vilas operárias na cidade de São

Paulo. São Paulo, Nobel, 1985.

BOITO, Camillo. Os Restauradores. Cotia, SP: Ateliê Editorial, 2003.

BONADIO, Geraldo. Sorocaba: a cidade Industrial (espaço urbano e vida social sob o impacto da atividade fabril). Sorocaba, SP: do Autor, 2004.

BONDUKI, Nabil Georges. Origens da habitação social no Brasil. São Paulo, Estação Liberdade/Fapesp, 1998.

BRANDI, Cesare. Teoria da Restauração. Cotia, SP: Ateliê Editorial, 2004.

BUENOS AIRES (Cidade). Guia Patrimônio Cultural de Buenos Aires. Vol. 6. Arquitectura Industrial. Buenos Aires, Direccion General de Patrimônio, 2006.

CARBONARA, Giovanni. Avvicinamento al Restauro. Teoria, Storia, Monumenti. Napoli, Linguori, 1997. 
CARBONARA, Giovanni. Brandi e a Restauração Arquitetônica Hoje. Desígnio, 2006 (2007), n.6, pp. 35-47.

CASIELLO, Stella. (Org.). La Cultura del Restauro: Teorie e Fondatori. 3a ed. Veneza, Marsílio Editori, 2005.

CEDODAL - Centro de Documentación de Arte y Arquitectura Latinoamericana. Miradas Sobre el Patrimonio Industrial. Buenos Aires: CEDODAL, 2007.

CÉSAR, Francisco Camargo. "Sorocaba Industrial". In: WERNECK, Bráulio (Org.) Almanach Illustrado de Sorocaba. Repositório histórico, literário e recreativo com ilustrações. Sorocaba/SP: Typographia Werneck, 1914, pp.38-92.

CHOAY, Françoise. A alegoria do patrimônio. São Paulo, Editora UNESP, 2001.

CORDEIRO, José Manuel Lopes. Arqueologia Industrial: Um Mundo a Descobrir, um Mundo a Defender. In: Patrimônio Industrial: perspectivas e abordagens: Coletânea de Textos do I Encontro em Patrimônio Industrial. Universidade Estadual de Campinas/Comitê Brasileiro de Preservação do Patrimônio Industrial. Campinas, SP. Novembro de 2004.

CORREIA, Telma de Barros; GHOUBAR, Khaled; MAUTNER, Yvonne. "Brasil, suas fábricas e vilas operárias." In: PÓS - Revista do Programa de Pós-Graduação em Arquitetura e Urbanismo da FAUUSP/Universidade de São Paulo. Faculdade de Arquitetura e Urbanismo. Comissão de PósGraduação - v.1 (1990) - São Paulo: FAU, 1990 - n. 20, dez. 2006.

COSSONS, Neil. The BP Book of Industrial Archaeology. London: David \& Charles, 1978, 3 a ed.

CUNHA, Claudia dos Reis e. O patrimônio cultural da cidade de Sorocaba: análise de uma trajetória. 2005. Dissertação (Mestrado em Arquitetura e Urbanismo) - Universidade de São Paulo, São Paulo, 2005.

CUNTO, João de. "A Indústria em Sorocaba", In: WERNECK, Bráulio (Org.) Almanach Illustrado de Sorocaba. Repositório histórico, literário e recreativo com ilustrações. Sorocaba/SP: Typographia Werneck, 1914, pp.236-238.

DURSKI, Julio Wieczerski. Álbum Photográphico, Vistas de Sorocaba 1879-1895. Sorocaba, SP: Atelier Photographico de Julio W. Durski, Reimpressão 2008.

DVOŘÁK, Max. Catecismo da Preservação de Monumentos. São Paulo: Ateliê Editorial, 2008.

FRAMPTON, Kenneth. História Crítica da Arquitetura Moderna. São Paulo. Editora Martins Fontes, 1997.

FRANCISCO, Rita de Cássia. As Oficinas da Companhia Mogiana de Estradas de Ferro: Arquitetura de um Complexo Produtivo. Dissertação (Mestrado em Arquitetura e Urbanismo) Universidade de São Paulo, São Paulo, 2007.

FRIOLI, Adolfo. Sorocaba: Registros Históricos e Iconográficos. São Paulo. Editora Laserprint, 2003. 
FRIOLI, Adolfo, BONADIO, Geraldo (org.). Sorocaba 350 Anos: Uma História Ilustrada, Sorocaba: Fundação Ubaldino do Amaral, Abr. 2004.

FUNDAÇÃO UBALDINO DO AMARAL. Sorocaba 350 Anos. Suplemento do Jornal Cruzeiro do Sul, Sorocaba, 15.8.2004, p.40.

GONZÁLEZ-VARAS, Ignácio. Conservación de Bienes Culturales: Teoria, Historia Principios y Normas. 4a ed. Madrid, Cátedra, 2005.

GUNN, Philip; Correa, Telma de Barros. Ascensão e Declínio de um Modo de Morar: Vilas Operárias e Núcleos fabris no Estado de São Paulo. Desígnio, 2006 (2007), n. 6, PP. 143-163.

GUTIERRE, Janette. Floresta Nacional de Ipanema: Onde a Natureza Faz História. São Paulo, SP: G7 Editora, 2007.

HOBSBAWN, Eric; Ranger, Terance. A Invenção das Tradições. São Paulo, Paz e Terra, 2002.

INSTITUTO ANDALUZ DEL PATRIMONIO HISTÓRICO. Preservación de La Arquitectura industrial en Iberoamérica y España. Granada: Editociones El Partal S.L., 2001.

INSTITUTO HISTÓRICO, GEOGRÁFICO E GENEALÓGICO DE SOROCABA. Disponível em: $<$ http://www.ihggs.org.br> . Acesso em: 26.3.2007

JOKILEHTO, Jukka Ilmari. A History of Architectural Conservation. Oxford, ButterworthHeinemann, 1999.

LEITE, WALTER RINALDI. Santa Rosália é o Primeiro Bairro Planejado de Sorocaba. Revista A Cidade: Sorocaba de Todos Nós 351 Anos. Suplemento do Jornal Cruzeiro do Sul. Fundação Ubaldino do Amaral, Ano 1. Sorocaba, 2005, pp. 36-37.

LEITE, WALTER RINALDI. Extra Inaugura Hipermercado Hoje, às 9hs. Jornal Cruzeiro do Sul. Fundação Ubaldino do Amaral. Sorocaba, 18.7.2000, p. A-5

LEMOS, Carlos A. C. O que é Patrimônio Histórico. São Paulo, Brasiliense, 1981.

LYNCH, Kevin. A Imagem da Cidade. São Paulo. Editora Martins Fontes, 1999.

KÜHL, Beatriz Mugayar. Arquitetura do Ferro e Arquitetura Ferroviária em São Paulo: Reflexões Sobre sua Preservação. São Paulo, Ateliê Editorial: Fapesp; Secretaria da Cultura, 1998.

KÜHL, Beatriz Mugayar. Preservação da Arquitetura Industrial em São Paulo: Questões Teóricas. Relatório Científico. Grupo de Disciplinas de História da Arquitetura/ Departamento de História da Arquitetura e Estética do Projeto. Faculdade de Arquitetura e Urbanismo Universidade de São Paulo. São Paulo, 2005.

KÜHL, Beatriz Mugayar. Preservação do Patrimônio Arquitetônico da Industrialização: Problemas teóricos de Restauro. Cotia, SP: Ateliê Editorial, 2008. 
KÜHL, Beatriz Mugayar. Questões Teóricas Relativas à Preservação da Arquitetura Industrial. Desígnio. São Paulo, v-1, no. 1, pp.101-117, 2004.

KÜHL, Beatriz Mugayar. Restauração Hoje: Método, Projeto e Criatividade. Desígnio, 2006 (2007), n.6, pp. 19-34.

MEDRANO, Ricardo H. Resumo das Aulas do Prof. Nestor Goulart Reis Filho na Disciplina AUH 237 - Urbanização e Urbanismo no Brasil I. Cadernos de Pesquisa do LAP 19. São Paulo, FAUUSP, 1997.

MENDES, José M. Amado. Uma Nova Perspectiva Sobre o Patrimônio Cultural: Preservação e Requalificação de Instalações Industriais, In: Seminário Internacional História e Energia, 2., 1999, São Paulo. Potencial Estratégico de Cultura e Negócios. São Paulo: Fundação Histórico da Energia de São Paulo, 2000, pp. 155-169.

MENEGUELO, Cristina. Da Ruína ao Edifício: Neogótico, Reinterpretação e Preservação do Passado na Inglaterra Vitoriana. São Paulo: Annablume; FAPESP, 2008.

MONNIER, Gérard. O Edifício-Evento, a História Contemporânea e a Questão do Patrimônio. Desígnio, 2006 (2007), n.6, pp.11-18.

PINHEIRO, Maria Lucia Bressan. William Morris e a SPAB. Rotunda, 2004, n.3, pp22-35.

PINHEIRO, Maria Lucia Bressan. John Ruskin e As Sete Lâmpadas da Arquitetura. In: RUSKIN, John. A Lâmpada da Memória. Cotia, SP: Ateliê Editorial, 2008.

PREFEITURA MUNICIPAL DE SOROCABA. Disponível em: <http://www.sorocaba.sp.org.br> . Acesso em: 25.3.2007 .

PRESTES, Lucinda Ferreira. A Vila Tropeira de Nossa Senhora da Ponte de Sorocaba: aspectos socioeconômicos e arquitetura das classes dominantes (1750-1888) / Lucinda Ferreira Prestes. São Paulo: ProEditores, 1999.

PRESTES, Lucinda Ferreira. Sorocaba: o tempo e o espaço, séculos XVIII-XX. Tese (Doutorado em Arquitetura e Urbanismo) - Universidade de São Paulo, São Paulo, 2001.

RANGEL, Paulo R.. Máquinas do Tempo. Sorocaba, SP: Crearte, 2004.

REIS FILHO, Nestor Goulart, 1931-. Parecer sobre a destruição de parte da antiga fabrica Santa Maria, na cidade de Sorocaba. São Paulo, 1994. Parecer Técnico Encaminhado Ao Procurador do Meio Ambiente em Sorocaba, Dr. Arnaldo Marinho Martins Junior.

REIS FILHO, Nestor Goulart, 1931-. São Paulo e Outras Cidades. São Paulo. Editora Hucitec, 1994.

ROSSI, Aldo. A Arquitetura da Cidade. São Paulo: Editora Martins Fontes, 1995. 
RUFINONI, Manoela Rossinetti. Preservação do Patrimônio Industrial na cidade de São Paulo. Dissertação (Mestrado em Arquitetura e Urbanismo) - Universidade de São Paulo, São Paulo, 2004.

RUFINONI, Manoela Rossinetti. Preservação e Restauro Urbano: Teoria e Prática de Intervenção em Sítios Industriais de Interesse Cultural. Tese (Doutorado em Arquitetura e Urbanismo) - Universidade de São Paulo, São Paulo, 2009.

RUSKIN, John. A Lâmpada da Memória. Cotia, SP: Ateliê Editorial, 2008.

SAIA, Helena. Arquitetura e Indústria - Fábricas de Tecido de Algodão em São Paulo. Dissertação (Mestrado em Arquitetura e Urbanismo) - Universidade de São Paulo, São Paulo, 1989.

SALVO, Simona. Arranha-céu Pirelli: Crônica de uma Restauração. Designio, 2006 (2007), n. 6, pp. 69-86.

SALVO, Simona. Restauro e 'Restauros' das Obras Arquitetônicas do Século 20. Intervenções em Arranha-céus em Confronto, Revista CPC, 2007, n.4, PP. 139-157.

SANCHES, Gilson. Retratos de Ipanema: Fatos e Imagens do Araçoiaba e Ipanema. Sorocaba, SP: Crearte, 2008.

SANTOS, Ademir Pereira dos. Arquitetura Industrial: São José dos Campos. São José dos Campos, SP: A. P. Santos, 2006.

SANTOS, Elina. A Industrialização de Sorocaba: Bases Geográficas. São Paulo. Editora Humanitas FFLCH/USP. Série Teses, 1999.

SCHERER, Rebeca. História, Teoria e Método nos Estudos de Urbanização. In: PÓS - Revista do Programa de Pós-Graduação em Arquitetura e Urbanismo da FAUUSP/Universidade de São Paulo. Faculdade de Arquitetura e Urbanismo. Comissão de Pós-Graduação. Número especial. São Paulo, 1995.

SILVA, Wesley Carlos da. Cianê: Auge, Decadência e Outras Histórias. Sorocaba, SP: do autor, 2009.

THOMAZ, Dalva; GIANNECCHINI, Ana Clara; ARRUDA, Valdir. Estudo para o tombamento do Patrimônio Industrial na orla ferroviária em torno da Estação da Mooca. Estudo apresentado à STCT-DP-DPH-SMC-PMSP, 2007.

UNIVERSIDADE PRESBITERIANA MACKENZIE. Apresentação de Trabalhos Acadêmicos: guia para alunos da Universidade Presbiteriana Mackenzie/ Universidade Presbiteriana Mackenzie. - 3a Edição. São Paulo. Editora Mackenzie, 2005.

VIOLLET-LE-DUC, Eugène Emmanuel. Restauração. Cotia, SP: Ateliê Editorial, 2000. 
WERNECK, Bráulio (Org.) Almanach Illustrado de Sorocaba. Repositório histórico, literário e recreativo com ilustrações. Sorocaba/SP: Typographia Werneck, 1950. 